Universidade de São Paulo

Escola de Comunicações e Artes

BRUNO HINGST

Projeto ideológico cultural no regime militar: o caso da Embrafilme e os filmes históricos e adaptações de obras literárias 


\title{
Projeto ideológico cultural no regime militar: o caso da Embrafilme e os filmes históricos e adaptações de obras literárias
}

\begin{abstract}
Tese apresentada ao Programa de Pós-Graduação em Meios e Processos Audiovisuais da Escola de Comunicações e Artes da Universidade de São Paulo, como exigência parcial para a obtenção do título de Doutor em Meios e Processos Audiovisuais, sob orientação da Profa. Dra. Marília da Silva Franco.
\end{abstract}

Área de Concentração: Meios e Processos Audiovisuais

Linha de pesquisa: Práticas da cultura audiovisual.

São Paulo 
Autorizo a reprodução e divulgaçâo total ou parcial deste trabalho, por qualquer meio convencional ou eletrônico, para fins de estudo e pesquisa, desde que citada a fonte.

Catalogação na Publicação Serviço de Biblicteca e Documentação

Escola de Comunicaçőes e Artes da Universidade de São Paulo Dados fornecidos pelo(a) autor(a)

HINGST, BRUNO

Plujelu illeuloyico cullutal hu teyius mililas: : u lebu da Embrafilme e og f. 1 meg h-gtóricose adantacīes tle obrag literarias / BRUNO HINGST. -- São Paulo: B. HINGST, 2013. $292 \mathrm{p}$.

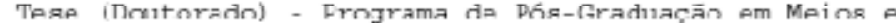
Processos Audiovisuais - Escola de Ccmunicaçōes e Artes / Universidade de Sāo Paulo.

OrienLadur: MARILIA DA SILVA FRANCO

Rihlingrafia

1. cinema 2. cinena nacional 3. regine militar 4. Eilme lisboricu 5. deleplaçäu de ubra lilerála Z. FRANCO, MARILIA חZ STTVA TT. Tít117

CDI 21.ed. - 302.2 


\section{FOLHA DE APROVAÇÃO}

Nome: HINGST, B

Título: Projeto ideológico cultural no regime militar: o caso da Embrafilme e os filmes históricos e adaptações de obras literárias

Tese apresentada ao Programa de PósGraduação em Meios e Processos Audiovisuais da Escola de Comunicações e Artes da Universidade de São Paulo, como exigência parcial para a obtenção do título de Doutor em Meios e Processos Audiovisuais, sob orientação da Profa. Dra. Marília da Silva Franco

Aprovado em:

\section{Banca Examinadora}

Prof. Dr. Instituição

Julgamento Assinatura

Prof. Dr. Instituição

Julgamento Assinatura

Prof. Dr. Instituição

Julgamento Assinatura

Prof. Dr. Instituição

Julgamento Assinatura

Prof. Dr. Instituição

Julgamento Assinatura 


\section{À minha mãe Sara, Pelo seu estímulo ao conhecimento}

À Gilda, Parceira de todas as horas

À família, Um apoio sempre presente. Aos amigos. 
À minha orientadora, Profa. Dra. Marília, pelo apoio e estímulo durante o percurso deste trabalho.

Ao cineasta Roberto Farias, por me receber e dividir suas experiências.

Ao Prof. Máximo Barro, pelo exemplo de amor ao cinema. Ao colega André Gatti, pelas opiniões e sugestões. A todas as pessoas que direta ou indiretamente participaram desta caminhada. 


\section{RESUMO}

HINGST, B. Projeto ideológico cultural no regime militar: o caso da Embrafilme e os filmes históricos e adaptações de obras literárias. 2013. Tese (Doutorado) Escola de Comunicações e Artes, Universidade de São Paulo, São Paulo, 2013.

Este trabalho tem como objetivo compreender o papel da Embrafilme no estímulo à produção de filmes de temática histórica e adaptações de obras literárias, seja através das formas de financiamento tradicionais, seja através da Carteira de Coproduções de Filmes Históricos e do Programa Especial de Pesquisa de Temas para Filmes Históricos, considerando a conjuntura política e cultural do governo Geisel (19741979). Para tanto, realizou-se pesquisa documental e bibliográfica visando esclarecer se este fomento à produção cinematográfica seria o resultado da implementação de uma política mais ampla voltada ao setor. A partir do material consultado, buscou-se conhecer as principais diretrizes do governo Geisel dirigidas à área cultural, avaliando sea(as) estas foram determinantes para orientar o incentivo à produção de filme de gênero histórico e adaptações de obras literárias. Os resultados indicam que o incentivo oferecido pela Embrafilme a estas temáticas de filme fez parte de uma estratégia levada a cabo pela direção da empresa, sem que houvesse uma política de governo específica que determinasse esse apoio. Também concluiu-se que a produção cinematográfica de filme de temática histórica e deadaptações de obras literárias foi significativa no período, levando-se em conta o curto período em que o incentivo foi oferecido.

Palavras-chave: cultura, cinema brasileiro, regime militar, filme histórico, adaptação de obra literária 


\begin{abstract}
An ideological cultural project under the Brazilian military regime: The role of Embrafilme in historical films and screen adaptations of literary works

The purpose of this study have to investigate the importance of the role by Embrafilme-the Brazilian Film Agency-in stimulating the production of thematic historical films and screen adaptations of literary works, either by means of traditional forms of funding or through the Special Program for Research of Themes for Historical Cinema, considering the political and cultural context of the Geisel government (19741979). To this end, desk research and a literature survey were conducted to clarify whether Embrafilme's incentive for film production stemmed from a broader policy for the sector. The material thus retrieved served to expound on core guidelines of the federal government for the cultural sector and to evaluate whether they were instrumental in orienting the incentive offered for the production of historical film and screen adaptations of literary works. The results revealed that Embrafilme's incentive for these thematics was part of a strategy initiated by the agency's management board in the absence of any specific governmental policy shaping this support. For both thematics, production was significant over the timeframe investigated, when measured against the short period in which incentives were available.
\end{abstract}

Keywords: culture, Brazilian cinema, military regime, historical film, adaptation of literary work 


\section{RESUMEN}

El proyecto ideológico cultural en el régimen militar brasileño - El caso de Embrafilme, los filmes históricos y las adaptaciones de obras literarias

Este trabajo tiene como objetivo comprender la importancia del papel de Embrafilme en el estímulo a la producción brasileña de películas de temática histórica y adaptaciones de obras literarias, tanto mediante las formas de financiamiento tradicionales como del Programa Especial de Investigación de Temas para Filmes Históricos, considerando la coyuntura política y cultural del gobierno de Geisel (1974-1979). Para ello, se realizó una investigación documental y bibliográfica a los efectos de esclarecer si este fomento de la producción cinematográfica fue producto de la implementación de una política más amplia dirigida al sector. A partir del material consultado, se procuró conocer las principales directrices del gobierno de Geisel en el sector cultural, evaluando si fueron determinantes para orientar el incentivo a la producción de películas del género histórico y adaptaciones de obras literarias. Los resultados indican que el incentivo de Embrafilme a estos temáticas cinematográficas formó parte de una estrategia conducida por la dirección de la empresa, sin que hubiera una política de gobierno específica que determinara este apoyo. También se concluyó que la producción cinematográfica de filmes de temática histórica y adaptaciones de obras literarias fueron significativas, considerándose el corto lapso durante el cual se ofreció el estímulo.

Palabras claves: cultura, cine brasileño, régimen militar, películas históricas, adaptaciones de obra literaria 


\begin{tabular}{|c|c|}
\hline \multicolumn{2}{|r|}{ ABREVIATURAS } \\
\hline ACPB & Associação Cinematográfica de Produtores Brasileiros \\
\hline AERP & Assessoria Especial de Relações Públicas / Cult-reg \\
\hline $\mathrm{Al}-5$ & Ato Institucional n. $5 / 141$ \\
\hline AIB & Ação Integralista Brasileira \\
\hline ALN & Aliança Libertadora Nacional \\
\hline AP & Ação Popular \\
\hline ARENA & Aliança Renovadora Nacional \\
\hline BNDE & Banco Nacional para o Desenvolvimento \\
\hline CAIC & Comissão de Auxílio à Indústria Cinematográfica \\
\hline Camde & Campanha da Mulher pela Democracia \\
\hline CFC & Conselho Federal de Cultura \\
\hline CGT & Comando Geral dos Trabalhadores \\
\hline Cibrazem & Companhia Brasileira de Armazenagem / 161 \\
\hline CJB & Cine Jornal Brasileiro \\
\hline CLT & Consolidação das Leis do Trabalho \\
\hline CMC & Comissão Municipal de Cinema \\
\hline CNC & Conselho Nacional de Cinema \\
\hline CNDA & Conselho Nacional de Direito Autoral / Cult-reg \\
\hline CNRC & Centro Nacional de Referência Cultural \\
\hline Concine & Conselho Nacional de Cinema / 165 \\
\hline $\mathrm{CPC}$ & Centro Popular de Cultura \\
\hline CSC & Conselho Superior de Censura / 186 \\
\hline CSN & Companhia Siderúrgica Nacional \\
\hline DAC & Departamento de Assuntos Culturais \\
\hline DAP & Departamento de Análise de Projetos / 171 \\
\hline DASP & Departamento Administrativo do Serviço Público \\
\hline DCDP & Divisão de Censura de Diversões Públicas /176 \\
\hline DFB & Distribuidora de Filmes Brasileiros \\
\hline DIP & Departamento de Imprensa e Propaganda \\
\hline $\mathrm{DNI}$ & Departamento Nacional de Informações \\
\hline DNP & Departamento Nacional de Propaganda \\
\hline DOI-CODI & $\begin{array}{l}\text { Destacamento de Operações de Informações/ Centros de } \\
\text { Operações de Defesa Interna /176 }\end{array}$ \\
\hline DOP & Departamento Oficial de Propaganda \\
\hline DOPS & Delegacia de Ordem Política e Social /176 \\
\hline DOU & Diário Oficial da União \\
\hline Doutrina & Doutrina de Segurança Nacional \\
\hline DPDC & Departamento de Propaganda e Difusão Cultural \\
\hline DPF & Departamento de Polícia Federal /177 \\
\hline$\overline{\mathrm{DSI}}$ & Divisão de Segurança e Informações do Ministério da Justiça /176 \\
\hline EAD & Escola de Arte Dramática \\
\hline Eletronorte & Centrais Elétricas do Norte do Brasil S.A \\
\hline Embrafilme & Empresa Brasileira de Filmes / 162 \\
\hline ESG & Escola Superior de Guerra \\
\hline FMI & Fundo Monetário Internacional \\
\hline FNDE & Fundo Nacional de Desenvolvimento da Educação \\
\hline Funarte & Fundação Nacional das Artes / 165 \\
\hline GEIC & Grupo de Estudos da Indústria Cinematográfica \\
\hline Geicine & Grupo Executivo da Indústria Cinematográfica \\
\hline GPO & Government Post Office Film-Unity \\
\hline I Convenção & Primeira Convenção Nacional da Crítica Cinematográfica \\
\hline IBESP & Instituto Brasileiro de Economia e Sociologia e Política \\
\hline
\end{tabular}




\begin{tabular}{|l|l|}
\hline II PND & II Plano Nacional de Desenvolvimento \\
\hline INC & Instituto Nacional de Cinema \\
\hline INCE & Instituto Nacional de Cinema Educativo \\
\hline INL & Instituto Nacional do Livro \\
\hline INPS & Instituto Nacional de Previdência Social / 161 \\
\hline Ipes & Instituto de Pesquisas e Estudos Sociais \\
\hline IPHAN & Instituto do Patrimônio Histórico e Artístico Nacional \\
\hline ISEB & Instituto Superior de Estudos Brasileiros \\
\hline MAM & Museu de Arte Moderna \\
\hline MASP & Museu de Arte de São Paulo \\
\hline MDB & Movimento Democrático Brasileiro \\
\hline MEC & Ministério da Educação e Cultura \\
\hline MIC & Ministério da Indústria e Comércio \\
\hline MJ & Ministério da Justiça \\
\hline MPB & Música Popular Brasileira \\
\hline PNC & Política Nacional de Cultura \\
\hline PAC & Programa de Ação Cultural \\
\hline PCB & Partido Comunista Brasileiro \\
\hline PCH & Programa de Reconstrução de Cidades Históricas \\
\hline PE & Planejamento Estratégico \\
\hline Petrobras & Petróleo Brasileiro S/A \\
\hline PNC & Plano Nacional de Cultura \\
\hline PSD & Partido Social Democrático \\
\hline PTB & Partido Trabalhista Brasileiro \\
\hline SCDP & Serviço de Censura e Diversões Públicas \\
\hline Sigab & Setor de Imprensa do Gabinete /176 \\
\hline SNI & Serviço Nacional de Informações / 176 \\
\hline SNT & Serviço Nacional de Teatro \\
\hline Sucom & Superintendência de Comercialização / 171 \\
\hline Suprod & Superintendência de Produção / 171 \\
\hline TBC & Teatro Brasileiro de Comédia \\
\hline UDN & União Democrática Nacional \\
\hline UNE & União Nacional dos Estudantes \\
\hline USP & Universidade de São Paulo \\
\hline W. Guilherme & Wanderley Guilherme \\
\hline Werneck Sodré & Nelson Werneck Sodré \\
\hline & \\
\hline
\end{tabular}




\section{SUMÁRIO}

$\begin{array}{ll}\text { INTRODUÇÃO } & 13\end{array}$

10 BRASIL: DOS ANOS 1930 AOS ANOS 1960

1.1 A REPÚBLICA: TRANSFORMAÇÕES POLÍTICAS, SOCIAIS E ECONÔMICAS 15

1.2 A ERA VARGAS 30

1.2.1 A cultura e o Regime $\quad 48$

1.2.2 O cinema no Estado Novo

$\begin{array}{ll}\text { 1.2.2.1 O Cinema Educativo } & 62\end{array}$

1.2.2.2 Plano Político Cinematográfico 64

1.2.2.3 O Cinema como Indústria $\quad 67$

1.2.2.4 Fim do Estado Novo: uma nova fase para o Cinema Nacional $\quad 70$

$\begin{array}{ll}1.3 \text { OS ANOS JK } & 71\end{array}$

1.3.1 O Projeto Desenvolvimentista 72

1.3.2 O ISEB: Um Novo Olhar para o Brasil $\quad 79$

2. ARTE, POLÍTICA E CULTURA NOS ANOS 1950 A 1964: A BUSCA PELA

IDENTIDADE BRASILEIRA 109

2.1 O CINEMA NACIONAL 111

2.1.1 As Novas Companhias Cinematográficas $\quad 111$

2.1.2 O Estado e a Regulamentação do Setor 112

2.1.2.1 O Grupo de Estudos da Indústria Cinematográfica 117

$\begin{array}{ll}\text { 2.1.2.2 O Grupo Executivo da Indústria Cinematográfica } & 118\end{array}$

2.1.2.3 A Comissão de Auxílio à Indústria Cinematográfica 120

$\begin{array}{ll}\text { 2.1.2.4 O Instituto Nacional de Cinema (INC) } & 121\end{array}$

2.2 O PCB E A MILITÂNCIA ARTÍSTICA E INTELECTUAL 123

2.3 O CINEMA NOVO 134

2.4 CULTURA E POLÍTICA NO PERÍODO PRÉ-1964 140

2.5 CULTURA: OS ANOS 1964-1968 147

2.6 CULTURA: Al-5, REPRESSÃO E DISTENSÃO 
3.1 O SISTEMA POLÍTICO 161

3.2 A DOUTRINA DA ESCOLA SUPERIOR DE GUERRA 165

3.3 O GOVERNO MÉDICI E O PROGRAMA DE AÇÃO CULTURAL (PAC) 167

3.4 O GOVERNO GEISEL E O PLANO NACIONAL DE CULTURA (PNC) 170

3.4.1 A gestão Ney Braga: uma política para a cultura 176

3.5 A EMBRAFILME $\quad 177$

$\begin{array}{ll}\text { 3.5.1 A gestão Farias } & 178\end{array}$

3.6 CULTURA COMO LEGITIMAÇÃO DO REGIME

3.7 A CENSURA: 1964-1985 208

4 HISTÓRIA E LITERATURA NO CINEMA NACIONAL: A PRODUÇÃO DA EMBRAFILME (1974-1978)

4.1 A HISTÓRIA NO CINEMA 224

4.2 CINEASTAS, ESTADO E POLÍTICAS DE CINEMA 238

4.3 GESTÃO PASSARINHO: ENSAIO DE UMA POLÍTICA PARA O CINEMA NACIONAL 249

4.4 GESTÃO FARIAS: CAMINHOS PARA O FILME HISTÓRICO E FILME DE ADAPTAÇÃO LITERÁRIA 253

CONCLUSÃO 261

REFERÊNCIAS 264

ANEXO A - Filmes Históricos (1974-1979) 275

ANEXO B - Adaptação de Obras literárias (1974-1979) 


\section{INTRODUÇÃO}

O interesse pelo tema da pesquisa começa com um questionamento pessoal, desenvolvido na dissertação de mestrado, intitulada Roberto Farias: Uma perspectiva comercial positiva para o Cinema Brasileiro, defendida junto à Faculdade Cásper Líbero e que buscou investigar a importância da gestão de Roberto Farias (1974-1978) à frente da Embrafilme, na implementação de uma perspectiva mercadológica na produção de filmes nacionais.

As informações obtidas durante a pesquisa para este trabalho indicaram a existência, nesse mesmo período, de uma significativa produção de filmes que abordavam episódios e personagens da História do Brasil e filmes que adaptavam obras literárias de autores nacionais e que contrastava com a produção esparsa de outros períodos, produzidas a partir de iniciativas independentes, isto é, sem o apoio do Estado.

Esse quadro trouxe algumas indagações que não puderam ser respondidas na pesquisa inicial e que agora se buscou esclarecer. Teriam existido, no período da gestão Farias na Embrafilme, políticas específicas para o fomento da produção de filmes históricos e adaptações de obras literárias? E, se existiram, seriam elas parte de uma política de Estado, implantada pelo governo Geisel, voltada para a área cinematográfica, especificamente de apoio a esses gêneros de produção cinematográfica?

No desenvolvimento deste trabalho buscou-se compreender o projeto ideológico do regime militar, criado a partir da Doutrina da Escola Superior de Guerra (ESG) e sua interferência no campo cultural, particularmente na área cinematográfica brasileira, e se a produção de filmes com temática histórica ou de adaptação literária fez parte de uma estratégia do governo Geisel voltada a reforçar o projeto nacionalista dos militares.

Foi, também, propósito desta pesquisa compreender o contexto histórico e social brasileiro, no período em que o regime militar dava início a um processo de distensão, bem como a relação do Estado com os cineastas brasileiros, intermediada por Roberto Farias, na Embrafilme e pelo Ministro da Educação e Cultura, na época, Ney Braga (1974-1979). 
Outra busca desta pesquisa foi a de identificar e relacionar a produção de filmes históricos e adaptações de obras literárias a partir dos anos 1910 até o ano de 1978, desenvolvendo uma avaliação da produção relativa ao período que vai de 1974 a 1978, obtida por meio do Programa Especial de Pesquisa de Temas para Filmes Históricos e das formas tradicionais de financiamento, incentivos oferecidos pela Embrafilme, entre 1974 a 1979.

Ao longo deste trabalho, desenvolvido em quatro capítulos, procuramos apresentar ao leitor um panorama histórico e considerações sobre o tema desta pesquisa.

O primeiro capítulo, O Brasil: Dos anos 1930 aos anos 1960, parte da necessidade de se construir um conhecimento sobre como se dava a relação entre Estado e cultura, nos governos anteriores ao golpe de 1964, e também apresentar as principais iniciativas desses governos voltadas ao incentivo do cinema brasileiro.

O segundo capítulo, Arte, política e cultura nos anos 1960: A busca pela identidade brasileira, vai trazer uma síntese das principais manifestações culturais brasileiras do período, apresentando a atuação do Estado para a regulação do cinema nacional, inclusive durante o regime militar, evidenciando a importante contribuição da militância política na cultura brasileira, principalmente no período de maior repressão.

O terceiro capítulo, O regime militar no Brasil, desenvolve uma reconstituição histórica do período pós-1964, investiga as características do regime e o papel da cultura na manutenção do projeto de poder do governo militar brasileiro.

O quarto capítulo, Gestão Farias: caminhos para o filme histórico e filme de adaptação literária, desenvolve um entendimento sobre filme histórico e adaptações de obras literárias, faz uma análise das principais políticas direcionadas à área cinematográfica e, com base na produção arrolada e nos resultados obtidos com a Carteira de coprodução de filmes históricos e o Programa Especial de Pesquisa de Temas para Filmes Históricos, se confirma nossa hipótese sobre a possível existência de uma efetiva política de governo, própria a esta produção.

Como o tema envolvia o conhecimento do processo histórico e cultural do país, optou-se pelo levantamento bibliográfico, de documentação relativa à Embrafilme e ao cinema nacional, enriquecido com entrevistas orais, sem organização estruturada de perguntas. 


\section{BRASIL: DOS ANOS 1930 AOS ANOS 1960}

\subsection{A REPÚBLICA: TRANSFORMAÇÕES POLÍTICAS, SOCIAIS E ECONÔMICAS}

Durante todo o período de seu reinado, D. Pedro II havia conseguido, habilmente, manter o sistema político estável e se firmar como símbolo de unidade nacional. Contudo, ao longo do tempo, os desgastes do seu governo começaram a ser notados por diferentes setores da sociedade brasileira: militar, civil e religioso.

Depois da Guerra do Paraguai, o exército brasileiro gozava de grande prestígio perante a sociedade brasileira devido à sua participação vitoriosa no conflito, contraditório com o sentimento de descrédito que acompanhava a tropa desde o período da Independência do Brasil, quando as mesmas apoiaram e participaram das agitações populares, criando um clima de desconfiança, propiciando que a Guarda Nacional gozasse de mais prestígio que o próprio Exército. Paralelamente, problemas mais sérios rondavam os quartéis, como o movimento de insatisfação devido aos soldos baixos, além da falta de estrutura e de equipamentos.

No plano hierárquico, o Exército brasileiro era uma instituição que questionava as estruturas políticas e sociais do Império. Com uma tropa formada por negros, os oficiais de alta patente criticavam o fato de o Brasil ainda ser a única nação independente da América a manter o regime de escravidão, de modo que ideias abolicionistas, republicanas e positivistas repercutiam cada vez mais nos quartéis, fazendo associar o atraso do país à forma de governo do Império.

Se no plano militar a situação também se mostrava delicada, no plano político um novo grupo social emergente da riqueza do café reivindicava maior participação no governo, ao lado das tradicionais oligarquias, os cafeicultores do oeste paulista, apesar da sua importância econômica para o país, sentiam que eram pouco atendidos pelo governo central e que não gozavam de pleno espaço no campo político.

A religião católica era a religião oficial do Império desde a Constituição de 1824 , fazendo da igreja uma Instituição com forte presença e grande influência na corte, poder que era motivo de um conflito permanente entre o Estado e o clero. O Estado tinha legalmente o direito de conceder ou negar validade a decretos eclesiásticos, o que obviamente não era bem aceito pela Igreja, que deveria acatar as decisões do 
Papa Pio IX. No caso do Brasil, o Vaticano definiu por orientar para que a Igreja pudesse ter uma maior autonomia perante o Estado.

O fato de o bispo de Olinda, Dom Vital, decidir colocar em prática, em 1872, a Bula Sylabbus, que trazia no seu contexto a proibição da união entre católicos e maçons, uma prática muito comum naquela época, deixa insatisfeito não só o Imperador, como também diversas pessoas de grande relevância social.

O rompimento definitivo das relações entre clero e Estado acontece (destacando aqui que a Igreja católica era um dos pilares de sustentação do Império, junto com a aristocracia rural e o Exército) quando da proibição da encomenda de uma missa em comemoração à fundação da loja maçônica pernambucana, episódio conhecido com a Questão Religiosa.

Numa tentativa de recuperar o prestígio e obter o apoio de segmentos mais significativos da sociedade, revertendo o desgaste a época, D. Pedro II adota uma série de medidas, tais como, concessão da autonomia provincial, liberdade de culto e ensino, facilidade de crédito que acabaram sendo negadas pelo Parlamento.

Já no final da década de 1880 se manifestava um quadro institucional complexo com a abolição da escravatura (1888), claramente por pressão dos ingleses, lembrando que o Brasil foi um dos últimos países a extinguir a escravidão no mundo.

\begin{abstract}
A produção do café, que vinha subindo de ano para ano, sofre um corte de $50 \%$ em 1888, devido à libertação dos escravos; esta quebra, entretanto, é economicamente compensada pelos bons preços correntes. A República se beneficia de certas condições nacionais e internacionais dos dois últimos decênios do século, e que são a causa do grande surto cafeeiro: baixa cambial resulta em emissões contínuas, o que significa abundância de capitais e necessidade de rápida aplicação para renda; assim, multiplicam-se empresas comerciais, industriais e rurais, principalmente as fazendas de café, que exigem grandes capitais. (CARONE, 1978, p.29)
\end{abstract}

No Brasil aconteciam diversas mudanças decorrentes da Revolução Industrial (1750) e da adoção da doutrina do Liberalismo e sua proposta de abertura dos mercados que não agradava principalmente à aristocracia rural, avessa à modernidade.

Aos olhos de todos era perceptível a deterioração da saúde física e mental do Imperador que, em caso de afastamento do cargo, teria como sucessora natural a Princesa Isabel, sua filha, uma pessoa que possuía grande aceitação e era muito popular junto às classes mais baixas e escravos, mas a chegada de uma mulher ao trono não era bem vista pela elite, machista.

O último gabinete do Império em 1889, liderado pelo liberal Afonso Celso de Assis 
Figueiredo, o visconde de Ouro Preto, foi mais uma tentativa de implementar as reformas reivindicadas pela oposição, fundamentadas em ideias republicanas, como a autonomia das províncias, a legislação agrária e o fim do voto censitário, numa tentativa de manter a estrutura monárquica de governo, mas que fracassou frente às dificuldades de aprovação.

No intuito de enfraquecer ainda mais o Exército, pela própria relação de desconfiança que tinha com ele, o governo vai então reforçar o contingente da Guarda Nacional e providenciar a transferência de batalhões militares, em meio a rumores de que essas unidades seriam extintas. Entre tantas incertezas políticas aumentam as articulações entre republicanos e militares visando convencer o marechal Deodoro da Fonseca a se colocar como líder do movimento republicano. Assim, em nove de novembro de 1889, no Clube Militar, com ação pela deposição do Imperador era iniciado ao mesmo tempo em que ocorria o "Baile da Ilha Fiscal", uma festa em homenagem à Marinha chilena, cheia de pompa, o último momento do Império, pois já estava sendo discretamente preparada a conspiração para derrubada da monarquia. Em 15 de novembro de 1889, o marechal Deodoro da Fonseca, pressionado por seus companheiros de Exército e temeroso que seus inimigos políticos chegassem ao poder, lidera o golpe contra o Imperador, que aceita o ultimato militar e sai do país, com sua família, para o exílio em Portugal.

A chegada da República marca, sem dúvida, uma mudança na sociedade brasileira, embora tenham sido apenas no plano político e econômico, ficando de fora questões também essenciais, de cunho social, como a qualificação profissional e a inserção social dos antigos escravos e a construção de moradias, também relegada ao segundo plano.

Nesse período há um crescimento progressivo dos centros urbanos, início de uma tentativa de modernização da estrutura política e social, quando nossas elites tinham sonhos ambiciosos, com a nova fase da humanidade "iluminada" pelas luzes do velho continente, a Europa. Essa fase modernizadora, iniciada na França, levou nossas elites, que procuravam diminuir as mazelas decorrentes de um regime colonialista e escravagista, inspiradas pelas forças inexoráveis da civilização e do progresso vindas da Europa. Importante salientar que a Europa também vivia mudanças no plano político e, principalmente, no econômico e social, geradas pelas transformações trazidas pela segunda Revolução Industrial.

Com o fim da Guerra do Paraguai e também a com a Abolição da escravidão, o país eliminava dois obstáculos que o impediam de alcançar maior respeitabilidade e 
Assim melhorar a sua imagem perante o mundo. Foram publicados livros que mostravam, com exagero, o quanto o Brasil era moderno no transporte, na educação e na área da comunicação, sendo apresentados em grandes eventos no exterior, como a Exposição de Paris, em 1889 e a Exposição Colombiana de Chicago, de 1883. (SKIDMORE, 2003, p.110)

O Brasil parecia sinalizar para um futuro voltado à modernidade, à liberdade e à adoção das doutrinas políticas liberais, que poderiam dar uma nova perspectiva ao país, mesmo que essa modernidade tivesse que conviver com as antigas oligarquias vinculadas ao café e à monocultura do açúcar.

Vemos que o período compreendido entre o final do Império e o início da República Velha (1889-1930), marca uma nova etapa da expansão das forças produtivas nacionais, como dos grupos sociais existentes, como a oligarquia dos cafeicultores e dos usineiros, da burguesia mercantil (maioria composta de estrangeiros) e da burguesia industrial (maioria de brasileiros).

Havia uma complexidade na formação da sociedade brasileira, que se dividia em três classes: alta (classes agrárias, profissionais liberais), média (imigrantes, segmentos de classes decadentes, liberais e militares) e baixa (funcionários públicos de baixa graduação e artesãos), além da classe operária, que vai aumentar paulatinamente nas grandes cidades em razão da mobilidade do trabalhador do campo e do imigrante em busca de melhores condições de vida. Juntando-se a esses segmentos sociais uma grande parcela da população, marginalizada, sem nenhuma instrução ou ofício, tais como escravos libertos (dispersos em povoados), matutos, caboclos, caipiras (no campo) e capangas e capoeiras (na cidade). (CARONE, 1978, p.147-148 e p.269-270)

A elite brasileira procurava se livrar de qualquer ranço ligado ao passado e havia claramente por parte desta um esforço para melhorar a imagem do país, bastante preocupada que estava com as questões da raça:

Ao contemplar sua posição, a elite brasileira pós-1870 logo caiu sob a influência de doutrinas europeias e norte-americanas de racismo científico, que apontavam a "evidência" biológica e histórica para justificar suas afirmações da superioridade branca. Essas afirmações, por sua vez, subjaziam a uma nova fase de expansionismo territorial europeu e norte-americano, com imperialismo e racismo avançando de mãos dadas. (SKIDMORE, 2003, p.112)

A elite brasileira, apesar de a população ser majoritariamente negra, queria reproduzir certos aspectos da ideologia racista presente em diversos estados norte-americanos, 
um país com uma população de brancos que excedia em número significativo a população de negros. Frente à dificuldade em repetir o modelo americano, o problema consistia então em encontrar uma solução que mantivesse sua condição de classe hegemônica e que preservasse o seu status quo. Uma das estratégias cogitadas seria a da miscigenação, pois devido à alta mortalidade da população afro-brasileira, aconteceria o "branqueamento" da população.

Nas palavras de João Batista de Lacerda, um importante médico e antropólogo, "no decorrer de mais um século os mestiços terão desaparecidos no Brasil. Isto vai coincidir com a extinção da raça negra em nosso meio". As confiantes palavras de Lacerda foram pronunciadas no Primeiro Congresso Universal de Raça em Londres, em 1911. (SKIDMORE, 2003, p.112-113)

Uma nova etapa do desenvolvimento chega à cidade do Rio de Janeiro, que era a capital do país e o principal centro das decisões políticas, econômicas e sociais, dando início a uma remodelação urbanística, com a remoção de cortiços, uma ampla campanha de saúde pública, que buscava conter epidemias, e a abertura de novas ruas e avenidas, a exemplo de Paris com seus belos e grandes boulevards.

É fato que a Revolução Industrial iniciou um processo de profundas mudanças e de evolução econômica sem precedentes na história da humanidade, desencadeando no período entre 1870 e 1900 o delineamento da revolução científica e tecnológica capitalista, preparando terreno para uma economia globalizada, centrada, entre outros aspectos, na questão dos princípios da racionalidade técnica.

Era como se a instauração do novo regime implicasse pelo mesmo
ato o cancelamento de toda a herança do passado histórico do país e
pela mera reforma institucional ele tivesse fixado um nexo
coextensivo com a cultura e a sociedade das potências
industrializadas. (SEVCENKO, 1999, p.27)

A estabilização entre oferta e procura de produtos em termos globais, depois de alguns anos de desaceleração econômica, permitiu a expansão dos negócios, tanto nos Estados Unidos como na Europa, gerando um clima de grande otimismo pelas possibilidades que a economia projetava. Os negócios geravam crescimento.

O enriquecimento baseado no crescimento explosivo dos negócios formou o pano de fundo do que se tornou conhecido como 'os belos tempos' (Belle Époque). (SEVCENKO, 1999, p.34)

Dentro do regime republicano, nossas elites foram mediadoras de um amplo processo de integração do país ao modelo de capitalismo, contribuindo para que se 
processassem rápidas transformações na sociedade brasileira ao introduzir no processo produtivo as práticas europeias mais modernas. É neste momento que a sociedade brasileira passa a absorver novos padrões de consumo.

Com a ajuda da publicidade, novas técnicas de promoção de produtos são introduzidas no país, criando novos hábitos de compra e de entretenimento, como o surgimento do mercado fonográfico, que se tornará massivo a partir da década de 1930, além das revistas ilustradas que abordavam, inclusive, assuntos desportivos. Em termos econômicos o Brasil era, entre 1900 a 1901, o maior produtor de café, responsável por $75 \%$ da produção mundial, posição que colaborava para que seus produtores tentassem manipular o mercado do preço final do produto. Os três grandes produtores de café na época eram os estados de São Paulo, Minas Gerais e Rio de Janeiro, que por fim assinam um acordo sobre a questão da especulação conhecida por valorização, acordo denominado de "Convênio de Taubaté", assinado em 1906, um mecanismo criado para que não houvesse a desestabilização do preço do café, o nosso principal produto de exportação.

Por meio desse convênio, os três estados que assinaram o acordo pretendiam limitar a produção e as exportações na esperança de obter o aumento dos preços internacionais do café em níveis superiores, anteriores a 1900, visto que o Brasil era um grande produtor. Este acordo acabou por não resolver o problema, ou seja, não conseguiu um aumento dos preços, mas por outro lado evitou uma grande queda no preço do produto em níveis que poderiam ser comprometedores para as reservas e o saldo da balança comercial brasileira. Para conseguir estocar o produto, o Brasil precisou recorrer a empréstimos externos, que mais tarde viriam agravar a situação econômica do país. Políticos e fazendeiros brasileiros, que tinham grande influência junto ao governo central, se valiam de instrumentos legislativos e financeiros para interferir nas operações de mercado, seja a nível internacional como nacional, fato que se repetiu em muitas economias subdesenvolvidas. Esse grupo acreditava que o poder do governo central deveria ser usado, em certos momentos, para regular determinadas questões do mercado, sobretudo aquelas que beneficiassem seus interesses, muito diferente do conceito clássico de laissez-faire, uma versão pura do capitalismo, que preconizava um mercado aberto e livre de interferência. (SKIDMORE, 2003, p.117) Devemos lembrar que o Brasil ainda era, na virada do século XIX para XX, um país pouco industrializado, com um modelo de produção lento e de pequena escala, apenas para o consumo interno. Fabricavam-se produtos que tivessem preço inferior ao dos concorrentes importados, ligados 
geralmente ao consumo básico das pessoas como, por exemplo, sabão, material de construção e bebidas. O setor têxtil fez parte do momento inicial da industrialização do país, já que a importação dos equipamentos era barata, ao passo que produtos da indústria pesada como trilhos, ferrovias, locomotivas e turbinas continuaram a ser importados por vários anos e essas importações pagas com os ganhos obtidos pela exportação de nossos principais produtos, café e borracha natural. (SKIDMORE, 2003, p.118)

Durante o governo do presidente Rodrigues Alves (1902-1906), o Brasil tinha uma situação econômica bastante positiva e estável, devido ao boom da exportação da borracha produzida na Amazônia e também fruto de uma administração saneadora por parte do seu antecessor, Campos Sales, que quitou as altas dívidas contraídas pelo país.

Assim, Rodrigues Alves pôde concentrar seu governo em ações de melhoria das condições urbanas da cidade do Rio de Janeiro, que beneficiariam tanto os moradores já estabelecidos, como também os novos imigrantes que vinham em busca dos novos postos de trabalho, criados em função da substituição da mão de obra escrava para atender os setores mais dinâmicos da economia do país.

Mas nem tudo no governo de Rodrigues Alves era bonança. O presidente enfrentou uma grave crise do café, o nosso principal produto de exportação, ocasionada por uma superprodução que levou à queda muito rápida e acentuada dos preços do produto no mercado nacional, obrigando os governos dos estados produtores como São Paulo, Minas Gerais e Rio de Janeiro a comprarem o excedente da produção, de modo a garantir os preços, para depois revendê-la quando o produto estivesse com um valor mais favorável.

Ante a falta de crédito oficial para a produção de café, aparece junto aos portos uma nova figura, os comissários de café, que passaram a desenvolver uma nova atividade ligada ao ramo cafeicultor, desenvolvendo duas atividades: agiam como casa bancária e como compradores de café. Além dos comissários, e por causa deles, aparece também a figura do ensacador, que comprava o produto dos comissários, para depois selecionar os tipos de grãos de café, de modo a atender as encomendas vindas exportador. (CARONE, 1978, p.36-37)

Mas são os representantes das grandes firmas estrangeiras, os exportadores, que têm o maior poder nesse processo, que vai da produção até a comercialização, mas a atuação deles no mercado não era bem aceita pelos comissários e pelos ensacadores. Porém, mesmo não sendo aceitos, os representantes aumentavam 
sua área de atuação, já que conheciam bem o mercado e sabiam como controlá-lo.

Sua ascendência deve-se ao fato de conhecer e controlar o mercado no país de origem e nas zonas de sua influência: sabe das necessidades de consumo; controla os embarques em seus navios e tem contratos com as redes comerciais internas de seu país. (CARONE, 1978, p.37)

O controle que os exportadores tinham do mercado foi fundamental para que eles se mantivessem ativos durante a crise de 1896, mudando sua forma de aquisição do produto, ou seja, passaram a comprar diretamente dos fazendeiros, eliminando da cadeia comercial os comissários e ensacadores, otimizando seus lucros a partir do aumento da especulação.

Assim, o Brasil, na época um dos maiores produtores de café no mundo, começava a se deparar com uma triste e desconhecida realidade: o país não tinha mais o controle direto do mercado de café, ficando os lucros nas mãos das empresas estrangeiras que, em certos casos, chegavam até a adotar práticas comerciais inescrupulosas, tais como, reensacar o café brasileiro e vendê-lo ao Brasil como sendo procedente de Java, obtendo assim enormes lucros.

No período de 1900 a 1910, o Brasil era o único produtor de borracha natural do mundo, matéria-prima extraída de seus seringais da Amazônia e exportada para os Estados Unidos, que a utilizavam para a fabricação de pneus de veículos automotores. Mas aos poucos a borracha brasileira vai perdendo espaço no mercado internacional na medida em que aumentava a produção inglesa e holandesa, que também plantaram seringueiras nas Índias Orientais, fazendo com que se encerrasse no Brasil o ciclo de riqueza e prosperidade gerado pelo produto, pondo fim ao monopólio comercial da borracha no país. (SKIDMORE, 2003, p.126)

A queda das exportações brasileiras da borracha não foi um caso isolado, visto que o país vivia em um contexto onde as grandes nações europeias cresciam alavancadas pela industrialização dos seus mercados e pela conquista de novos, impulsionadas que estavam pelo ideal liberalista, que defendia o direito à propriedade e o livre comércio, sendo contrário à qualquer interferência do Estado na economia, que seria uma forma de interferir na liberdade das pessoas e que poderia prejudicar o crescimento do país. Conforme Skidmore:

Além disso, a ideologia econômica predominante do liberalismo estilo Manchester, amplamente endossada pela elite brasileira, condenava firmemente a tentativa de industrialização em "países periféricos" como o Brasil. Ademais, havia forte oposição à industrialização por 
parte dos comerciantes urbanos, que tinham interesse óbvio em manter a dependência do Brasil da importação de bens manufaturados. (2003, p.127-128)

Apesar de o país ser, desde o início do século XX, dependente economicamente de duas matérias-primas de exportação, a borracha e o café, a perda desses monopólios depois de 1910 não impediu o seu crescimento, mas passou a evidenciar uma série de problemas estruturais a médio e longo prazo.

De fato, o crescimento econômico do país entre 1850 e 1913 foi relativamente alto pelos padrões internacionais, com uma média de $2,4 \%$ (valores constantes) ao ano. (A média anual de crescimento para a Europa ocidental e a América do Norte de 1870 a 1913 foi de $2,7 \%$ ). A dificuldade era que a população do Brasil, graças em parte à imigração, estava crescendo quase tão rapidamente, com uma média de 2,2\% ao ano. (SKIDMORE, 2003, p.126-127)

O país estava agora diante de outro momento crucial da economia, procurando soluções para melhorar sua renda per capita (um indicador para avaliar o seu grau de desenvolvimento econômico), de modo que o crescimento da população, causado pela imigração, viesse acompanhado da elevação do padrão de vida, o que na verdade não estava ocorrendo. Assim, o Brasil chegava a uma encruzilhada, precisando tomar decisões que implicassem em mudanças efetivas não só no plano econômico, mas também no plano político, na esperança de que essas mudanças trouxessem transformações sociais para o país, na forma de trabalho e aumento de salários e de qualidade de vida para a população. Para que as mudanças pudessem ser implantadas, três possibilidades foram pensadas. Segundo Skidmore (2003, p.127-128) eram elas:

A primeira opção seria a de desacelerar o crescimento populacional, reduzindo o estímulo à imigração e incentivando a formação de famílias menores, opção que não agradava nossas elites que, por estarem ligadas ao setor da agricultura, se beneficiavam com a elevação da população do país, para atender o plantio e a colheita da produção.

A segunda alternativa seria a de se acelerar o crescimento econômico, de forma a ultrapassar rapidamente o custo do crescimento da população. O Brasil tinha um limite para aumentar suas exportações por causa dos mercados estrangeiros e em consequência também seu crescimento interno.

E por fim, uma terceira alternativa seria focar no crescimento do mercado interno, direcionando os investimentos para setores que produziam para o mercado 
doméstico. Porém, essa alternativa tinha pela frente obstáculos como a carência que o país tinha de tecnologia e de bens materiais para que fosse iniciada uma produção em larga escala daqueles produtos.

\begin{abstract}
Mesmo se o Brasil tivesse optado por concentrar-se em seu mercado interno haveria necessidade de pesados investimentos. Como as exportações quase certamente não gerariam o capital excedente necessário para financiar esses investimentos, eles teriam de vir de dentro do Brasil. Mas isto exigiria taxas de poupança interna extraordinariamente altas. Para produzir essa poupança seria preciso exigir uma redução aguda no consumo, algo que poucas democracias, naquela época ou depois, chegaram a conseguir. (SKIDMORE, 2003, p.128)
\end{abstract}

A partir da segunda metade dos anos 1910, o governo de Afonso Penna (19061909) priorizou suas ações na implantação da política de valorização do café, comprando o excedente do produto, agravando ainda mais o endividamento do setor público, que continuava a contrair empréstimos no exterior para estocar café.

Penna falece antes de terminar seu mandato, sendo substituído pelo vice, Nilo Peçanha, que ocasiona a primeira crise política entre os dois principais estados da federação que haviam conquistado a hegemonia nacional. A disputa pela indicação do candidato à Presidência da República levou São Paulo e Minas Gerais a romperem relações firmadas no acordo oficial da política do "café com leite", com São Paulo unindo-se à Bahia e apoiando a candidatura de Rui Barbosa, enquanto Minas Gerais aliava-se ao Rio Grande do Sul e apoiava a candidatura do marechal Hermes da Fonseca, que acabou por vencer a disputa eleitoral.

O governo de Hermes da Fonseca (1910-1914) buscou realizar uma forma de governo que alterava a relação das forças existentes nas oligarquias tradicionais, favorecendo aliados políticos que eram ligados a outras oligarquias de menor influência no seu governo, além de realizar intervenções militares nos Estados, voltadas a destituir governadores e substituí-los por outros, nomeados diretamente pelo presidente. Esse modo de governar trouxe ao mandato de Hermes da Fonseca uma constante instabilidade política, devido às revoltas e rebeliões que surgiram nos Estados contra os interventores nomeados. As revoltas mais significativas foram a Revolta da Chibata (1910), um movimento contra as péssimas condições de trabalho dos marinheiros e a Guerra do Contestado (1912-1916), um conflito armado que tem origem nos problemas sociais, sobretudo na questão fundiária, que se deu à época da construção da ferrovia São Paulo-Rio Grande.

No governo sucessor de Hermes da Fonseca houve uma reaproximação dos estados 
de São Paulo e Minas Gerais, voltando a operar a tradicional política do "café com leite" que lançou candidato único, Venceslau Brás, que vence Pinheiro Machado, e que então vai governar o país de 1914 a 1918.

A chegada da I Guerra Mundial provocou um choque nas nossas elites que tinham uma grande identificação com o modo de vida europeu, cosmopolita e politicamente estável. A guerra que chegava até a Europa contradizia a estabilidade tão almejada por nossas elites, que passam então a buscar sua própria identidade. Por outro lado, a entrada do Brasil na I Guerra Mundial em resposta à pressão nacionalista gerou uma expectativa na sociedade brasileira de ver ampliada sua influência no cenário global, o que logo se mostrou equivocado.

O desencadeamento da I Guerra Mundial teria, em teoria, favorecido o Brasil em razão das restrições impostas ao comércio mundial, o que poderia fomentar seu processo de industrialização, ou seja, era um momento favorável para a indústria nacional investir na produção de produtos e mudar a condição de importador que o Brasil tinha até então.

\begin{abstract}
Pesquisas recentes mostraram, entretanto, que o suprimento de bens de capital importados, como máquinas operatrizes, não foi e não poderia ter sido substituído por produção doméstica. Assim, a queda nas importações de capital sofisticado provocada pela guerra na realidade atrasou a industrialização ulterior. Havia, porém, um aspecto positivo. O câmbio estrangeiro acumulado durante a guerra posteriormente ajudou a financiar a onda de compras de bens de capital depois de 1918. (SKIDMORE, 2003, p.139-140)
\end{abstract}

No entender de muitos políticos e intelectuais brasileiros, a elite brasileira acreditava que a participação do país no conflito credenciava o Brasil a ser um parceiro de maior relevância e influência dos países europeus. Diplomatas e políticos também avaliaram que o Brasil poderia, por conta de sua participação na guerra, reivindicar uma cadeira permanente na recém-criada Liga das Nações ${ }^{1}$. Apesar da intensa campanha para atingir esse objetivo, o pedido foi boicotado pela outras nações latino-americanas.

A Inglaterra, que destina pesados recursos financeiros para aumentar o esforço de guerra, acaba perdendo seu poder político e econômico para os Estados Unidos,

\footnotetext{
${ }^{1}$ Sociedade das Nações, ou Liga das Nações, foi uma organização internacional criada em abril de 1919, em Versalhes, na França, onde as potências vencedoras da I Guerra Mundial se reuniram para negociar um acordo de paz. A sede da organização passou em novembro de 1920 para a cidade de Genebra, na Suíça. Não possuindo forças armadas próprias, o poder de coerção da Liga das Nações baseava-se apenas em sanções econômicas e militares. Em abril de 1946, o organismo se autodissolveu, transferindo as responsabilidades que ainda mantinha para a recém-criada Organização das Nações Unidas, a ONU. Disponível em <http://cpdoc.fgv.br/producao/dossies/AEraVargas1/anos20/Centenariolndependencia/LigaDasNacoes>. Acesso em $18 / \mathrm{dez} / 2012$.
} 
que passou então a ampliar seu protagonismo político, econômico e comercial, que vai crescer daquele momento em diante. O Brasil foi beneficiado pela guerra, já que a diminuição da oferta do produto no mundo fez aumentar os preços do café produzido aqui.

\begin{abstract}
No decorrer da década de 1920, o investimento norte-americano e alemão na indústria brasileira aumentou significativamente, com o norte-americano indo de US\$ 50 milhões em 1914 para US\$ 557 milhões em 1930. Isto representava um aumento de mais de oito vezes na participação dos Estados Unidos no investimento estrangeiro total no Brasil. (SKIDMORE, 2003, p.141)
\end{abstract}

Isto acarretou uma situação paradoxal. Apesar da inflação elevada durante quase toda década de 1920 no país, o Brasil ampliou em 150\%, durante os anos de 1922 e 1929, suas exportações de café, e o preço elevado no mercado internacional trouxe um saldo positivo para nossa balança comercial. Segundo Skidmore, os ganhos com essas exportações foram utilizados no processo de industrialização do país, buscando se afastar da sua dependência agrícola. (2003, p.141)

Esses períodos de valorização do café causavam apreensão, pois o risco da superprodução, que já havia acontecido em outros momentos como em 1906, poderia acarretar graves prejuízos financeiros e até a quebra de muitos cafeicultores caso nenhuma ação de proteção fosse adotada. Assim, em 1926, é assinado um Convênio entre os estados produtores de café, que buscava conter os preços do produto. Outras medidas também foram tomadas em âmbito federal com os mesmos objetivos. O então presidente do estado de São Paulo (cargo equivalente hoje ao de governador), Carlos de Campos, cria no mesmo ano o Instituto do Café, com o objetivo também de desenvolver uma política de controle do fluxo do café no porto de Santos e de facilitação de crédito para os fazendeiros.

Esta política se traduz em novas construções de armazéns retentores; na distribuição compensada da safra, no prazo máximo de um ano; na ação dos agentes na Bolsa do Café em Santos, para a elevação do preço do produto e, conforme necessidade, para a retenção ou lançamento de lotes no mercado. (CARONE, 1978, p.49-50)

Ainda segundo Edgard Carone, todo esse controle governamental sobre os preços só faz aumentar a apreensão. Em 1927 a safra de café atinge a produção de 27.625.000 sacas, uma produção surpreendente. Por sua vez, os estoques em 1927 eram de 7.300.000, passando para 18.800.000 em 1929. (1978, p.50-51)

O final da década de 1920 foi marcado por uma grande bolha especulativa, que já 
vinha se desenvolvendo durante um bom tempo. As ações das empresas se encontravam sobrevalorizadas, fora de qualquer parâmetro da realidade, condição que levou ao crash da Bolsa de Valores de Nova lorque, arrastando grandes empresas, comerciantes, fazendeiros e até bancos para a falência, levando o mundo a uma grande depressão econômica, que demorará uma década para ser superada.

\begin{abstract}
A bolha econômica estourou quando a economia capitalista mundial entrou em colapso em 1929. O preço do café, que ainda respondia por $70 \%$ do cambio externo do Brasil, começara a cair ainda antes do crash de outubro de 1929 em Wall Street, declinando 50\% entre setembro de 1929 e janeiro de 1930. O Brasil perdeu todas as suas reservas camibiais estrangeiras em poucos meses com os comerciantes trocando sua moeda brasileira por ouro, dólares ou libras esterlinas. (SKIDMORE, 2003, p.142)
\end{abstract}

No caso do Brasil as consequências dessa crise econômica foram bastante trágicas, pois o café era responsável por boa parte das nossas receitas externas e o governo, ao adotar uma política ortodoxa obrigando a conversão da moeda brasileira em uma taxa fixa, condenou o país a utilizar todas as suas reservas cambiais, ocasionando uma grande instabilidade econômica.

As grandes economias do capitalismo haviam colapsado a partir da crise dos grandes centros financeiros, e para a Europa, os Estados Unidos, o Brasil e as demais economias periféricas não restaram muitas alternativas para recuperação. O governo brasileiro optou então por queimar os estoques excedentes de café para forçar gradualmente a elevação do preço do produto.

A recomendação dos especialistas era no sentido de cortar gastos e equilibrar o orçamento, um sentido mais ortodoxo de reordenamento das atividades econômicas, evitando o uso intensivo de recursos públicos (como o que aconteceu no governo de Rodrigues Alves) para não corroer as reservas nacionais. Se por um lado o uso dos recursos do Estado, contrariando as recomendações, foi bastante prejudicial ao país, por outro, favoreceu a expansão monetária, gerando um lento processo de recuperação da economia nacional, que trazia a esperança de que o processo de industrialização do país continuasse a caminhar.

No campo político, a década de 1920 testemunha diversas crises que têm início com a promulgação da Constituição de 1889, que instituía um sistema federativo, extremamente fragmentado, que permitia aos estados contrair empréstimos sem a anuência do governo, cobrar os impostos que quisessem nos limites dos estados, ou seja, havia uma grande autonomia dos estados em relação ao poder central. Devemos lembrar que os estados mais ricos, como os da região sudeste, geravam 
condições para o desenvolvimento industrial, enquanto que os estados da região nordeste possuíam uma tímida atividade comercial, com baixo desenvolvimento humano e altos índices de miséria, o que os militares viam como risco de desintegração social do país. As fraudes no sistema político e eleitoral, que podiam ser vistas nos estados e municípios de todo Brasil, também deixavam a sensação de que o sistema Republicano havia fracassado.

\begin{abstract}
Um segundo era a decepção com o fracasso da economia em crescer mais rapidamente, atribuído por muitos às faltas do sistema político. Em torno de 1920, a incapacidade do Brasil em igualar o desenvolvimento dos Estados Unidos e da Argentina era evidente a todos. As ambiciosas promessas republicanas do final da década de 1880 não haviam sido cumpridas. Embora tendo-se industrializado num certo grau, o Brasil permanecia dependente dos ganhos com a exportação basicamente de um único produto, o café, e havia fracassado em conseguir um assento no Conselho Permanente da Liga das Nações em 1926. (SKIDMORE, 2003, p.149)
\end{abstract}

As promessas não foram cumpridas e intelectuais e políticos faziam duras críticas ao sistema Republicano. Na década de 1920, um grupo de jovens tenentes, que sentia que o governo não tinha atendido aos seus anseios, resolveu fazer o uso das armas contra os políticos que estavam no poder. O movimento, que recebeu o nome de Tenentismo $^{2}$, tinha como reivindicação principal o fortalecimento da instituição militar, a moralização dos costumes políticos e a construção de um Estado centralizado que pudesse modernizar o país. Para muitos militares havia a percepção de que o país fracassara na sua busca pela modernidade e os tenentes, por sua vez, desejavam um governo forte, sem os políticos que enriqueciam com o dinheiro público, uma legislação progressista no campo social, um salário mínimo e uma legislação para o trabalho infantil.

No momento em que o governo procurava administrar os recentes reflexos da quebra da bolsa de 1929 e da perda de arrecadação com o café também tinham início os preparativos para a campanha presidencial, cercada de suspeitas, devido a manipulações políticas e o uso comum da máquina estadual para manipular os resultados das eleições.

Nessas eleições, a oposição era encabeçada pela chapa da Aliança Liberal que indicou Getúlio Vargas, ex-ministro das finanças e então governador do Rio Grande

\footnotetext{
2 O movimento tenentista também propunha outras reformas, como o fim do voto de cabresto, ou seja, voto que era comprado ou que o eleitor se via ameaçado a votar em determinado político, instituição do voto secreto e a reforma na educação pública. Os movimentos tenentistas foram: Revolta dos 18 do Forte de Copacabana que aconteceu em 1922, a Revolução de 1924, a Comuna de Manaus de 1924 e a Coluna Prestes, um movimento político-militar que durou de 1925 a 1927.
} 
do Sul, para concorrer à presidência, recebendo apoio de Minas Gerais, Rio Grande do Sul e da Paraíba. O candidato da situação era o paulista Júlio Prestes, apoiado pelos demais estados.

A oposição sabia dos riscos de manipulação para que a vitória ficasse com Júlio Prestes. Getúlio Vargas também tinha claro que a fraude pudesse acontecer, mas sabia também que muito pouco poderia ser feito, até que o assassinato de João Pessoa, seu vice na chapa, desencadeia vários focos agitação, organizados por Vargas e pelos governadores de Minas Gerais e dos estados rebeldes do nordeste, que depois receberam reforço do exército federal estacionado no Rio Grande do Sul e das colunas rebeldes que partiram para um enfrentamento e ataque ao governo federal.

No Rio de Janeiro o presidente Washington Luís estava decidido a ficar no cargo e fazer a transmissão para o seu sucessor natural. Contudo, os comandantes militares estabelecidos no Rio de Janeiro avaliaram que se adotassem uma atitude de apoio ao presidente, o país estaria sendo encaminhado para uma guerra civil. A intervenção do Cardeal D. Sebastião Leme, arcebispo do Brasil, convenceu o presidente Washington Luís a deixar o cargo, visto que o mesmo não tinha mais condições de se manter no poder, assim deixa o país e parte para o exílio. Aproveitando o vácuo no poder, os comandantes do Exército e da Marinha que estavam na cidade do Rio de Janeiro tomam a iniciativa, por conta própria, e assumem o governo de maneira "provisória", como junta governante e, imediatamente, começam a promulgar seus próprios decretos, claro, atos que não tinham nenhuma legalidade. Em pouco tempo, Getúlio Vargas liderando as tropas vindas da região sul, alcança a cidade do Rio de Janeiro e depois de negociação, é empossado pela junta governante como presidente provisório.

Vargas, a partir deste momento, passará pelos próximos 25 anos a ser uma das figuras de maior destaque no quadro da política nacional, inscrevendo o seu nome na história do país, com uma influência no campo político nunca antes vista, remodelando e, sobretudo, erigindo as bases para a modernização do Estado Brasileiro. Ditador, presidente em 1937 do Estado Novo, presidente eleito em 1950, seu ciclo de poder termina com seu suicídio em 1954.

A deposição de Washington Luís muda de maneira significativa o quadro político brasileiro, mudando o eixo da liderança e domínio que há décadas estava em São Paulo, para uma coalizão de líderes políticos de Minas Gerais e do Rio Grande do Sul, sob a liderança de Vargas. O país chegava a 1930 em um cenário de ruptura da 
estrutura política, com o fim da República Velha e o acesso de novos grupos políticos ao poder central, além do fato de que Vargas assumiria o poder com uma coalizão de forças extremamente heterogênea, em meio a grandes conflitos e divergências de interesses, que em pouco tempo exporá a instabilidade e as fissuras de seu governo.

Após 1930 vai haver modificação do domínio quase linear agrário. Estas classes continuam preponderantes, mas agora se dividem e subdividem, o que as enfraquece; proletariado e classes médias disputam o poder e se organizam em partidos, de tendências diversas, mas eles também se enfraquecem politicamente devido a suas divisões profundas. Por sua vez, a burguesia continua subordinada às oligarquias rurais, que chamaremos, para simplificar, também de classes agrárias ou rurais. (CARONE, 1977, p.143)

\subsection{A ERA VARGAS}

Apesar da atuação e domínio das classes agrárias ainda existirem, essas classes passam agora a ter maior projeção no cenário social e começam a se manifestar publicamente sem sofrerem repressão; a classe média e o operariado já começam a se organizar politicamente.

Vargas, como presidente do governo revolucionário (1930-1934), sinaliza outras demandas, principalmente no sentido de abrir novos rumos para o país no plano político e econômico. Ele desenvolve amplo projeto de modernização do Estado, visando uma integração nacional, através de um processo industrial de longo prazo, de modo a constituir um mercado efetivo que assegurasse uma nova etapa de desenvolvimento para o país, pois, se nos anos 1920 o café se consolidou como o maior produto na pauta de exportações brasileiras, esse quadro mudou radicalmente depois de 1929, quando aconteceu a quebra da Bolsa de Valores de Nova lorque, sinalizando o fim deste ciclo.

Vargas também tem que enfrentar movimentos políticos e revoltas sociais, como a Revolução Constitucionalista de 1932, quando os paulistas se rebelaram por se sentirem prejudicados e terem perdido parte do poder com a deposição do presidente Washington Luís em 1930, querendo então se separar do país. O fato é que os perdedores de 1930 foram muitos, desde os tradicionais mandantes do Partido Republicano que tinham apoiado Júlio Prestes, até os altos comandantes do exército que foram aposentados sumariamente, bem como banqueiros que queriam que 0 
país adotasse o padrão ouro. A derrota dos paulistas deixou a elite paulistana desacreditada perante todo o país, restringindo bastante a capacidade de atuação dos grupos paulistas no cenário da política nacional e, ainda, deixando muitas dúvidas sobre as reais intenções de Getúlio Vargas para com o Estado.

Getúlio foi obrigado a cumprir uma promessa feita antes da Revolta de 1932, garantindo a realização de eleições, que acontecessem em 1933, além de criar a Justiça Eleitoral, visando garantir a transparência e credibilidade das futuras votações. A Assembleia Constituinte redigiu e aprovou uma nova constituição promulgada em 1934, que mesclava liberalismo político e reformismo socioeconômico. Vargas será eleito por essa Assembleia para um mandato de quatro anos, esta que praticamente se tornará a Câmara dos Deputados, o que parecia encaminhar o país rumo a um projeto democrático.

A década de 1930 assiste uma radicalização no plano ideológico. De um lado a esquerda liderada pelo Partido Comunista Brasileiro (PCB) com Luís Carlos Prestes, e do outro lado do espectro político, a direita, uma parcela significativa da sociedade civil, representada pela Ação Integralista Brasileira (AIB), com grupos vinculados à Igreja Católica, que se identificava com o fascismo europeu congregando muitos seguidores entre as classes médias e altas, a Marinha e o clero. É uma década marcada pelo antagonismo entre a esquerda, com os comunistas, e a direita, com os Integralistas, um reflexo do que estava acontecendo na Europa, que também via acontecer marchas, confrontos e combates violentos.

Havia uma percepção naquele momento em que o sistema democrático tinha muitas falhas e o fascismo parecia oferecer soluções mais fortes para os supostos "desmandos" da democracia, como a falta de controle dos seus governantes sobre o povo e os rumos do país. O fato é que a Europa tinha nos anos 1930, governos fascistas: Itália (1925), Alemanha (1933) e Espanha (1936).

A esquerda, particularmente os comunistas, atuavam ao redor do mundo por meio dos partidos comunistas, na legalidade ou mesmo na ilegalidade, coordenados pela União Soviética e seu Comintern ${ }^{3}$, atuando para fomentar a revolução e a tomada do poder, motivo de preocupação para boa parte da classe média, para os banqueiros e os industriais e, principalmente, para o Exército.

O PCB existia desde 1922 no Brasil e tinha como meta realizar esforços e se concentrar nos trabalhadores urbanos para as mobilizações de ação e defesa da

3 Comintern ou Komintern, do alemão kommunistische internationale e que designam a Terceira Internacional ou Internacional Comunista, uma organização fundada em março de 1919 por Vladimir Lenin e pelo Partido Comunista da União Soviética (bolchevique), para reunir os partidos comunistas de diferentes países. 
causa, lutando acima de tudo por seus direitos. Contudo, nosso país representava um problema para os comunistas, pois era essencialmente agrário e seus trabalhadores rurais, além de estarem dispersos, também tinham muito pouca capacidade mobilização e potencialização de cunho revolucionário.

O objetivo do partido foi então o de focar suas ações nos trabalhadores urbanos, porém, mesmo isso era dificultoso, pois essa força de trabalho estava dispersa em pequenos estabelecimentos comerciais, já que o país possuía um número reduzido de indústrias de grande porte, inviabilizando uma mobilização geral, isso sem contar a resistência dos empregadores e a repressão que era constantemente feita a este tipo de organização e de ação política.

Logo os comunistas saem às ruas, em um movimento que culminou com a Intentona de 1935, quando, liderados por Luís Carlos Prestes que se encontrava em Moscou, tentaram tomar o poder fazendo uma frente esquerdista denominada Aliança Libertadora Nacional (ALN), que congregava também socialistas e outros partidos. Os combates entre comunistas e as forças do governo começaram em três bases militares, Natal, Recife e Rio de Janeiro, mas foram rapidamente sufocados, graças à ação de informantes infiltrados entre os comunistas que mantinham Getúlio bem informado e a ação das forças policiais do governo que tudo monitoravam.

Desta forma, logo nos primeiros meses do ano de 1935, Vargas comunica ao Brasil a instituição da Lei de Segurança, que aumentava as restrições às liberdades individuais. Getúlio Vargas, habilmente, como um político astuto, soube tirar proveito da Intentona Comunista, fazendo circular versões bastante exageradas dos fatos oficiais, que depois eram desmentidas pelos registros militares. Essa estratégia deu a Vargas o pretexto adequado para que ele conseguisse que o Congresso declarasse o Estado de Emergência (Estado de Sítio), que na prática suspendia os direitos civis, aumentava o poder policial e, sobretudo, aumentava o poder presidencial, ações que abrem o caminho para o golpe que vai culminar no Estado Novo.

As classes dominantes armam o governo de poderes excepcionais, certas de que os poderes só servem para dominar as facções contestantes, de origem operária, pequeno-burguesa ou mesmo de sua própria classe. Mas, após as prisões em massa e o extermínio do resto das instituições liberais, a divergência acaba contaminando os próprios grupos vencedores, que lutam pela conquista do poder governamental, num momento em que a sucessão presidencial de Getúlio Vargas galvaniza os dois pólos situacionais e oposicionistas. (CARONE, 1977, p.253)

Vargas, segundo à Constituição, não poderia concorrer ao segundo mandato, portanto 
seu principal oponente seria o industrial paulista, Armando de Salles de Oliveira, que disputaria as eleições contra seu candidato, o escritor e político nordestino José Américo de Almeida. Os paulistas, que apoiavam Armando Salles de Oliveira, pensavam que havia chegado o momento de voltar a ocupar o poder central, mas não sabiam que Getúlio já conspirava, com o Exército, um golpe de Estado, que acontece em 10 de novembro de 1937, quando o Congresso foi cercado por tropas federais, barrando o acesso dos congressistas. À noite, em cadeia de rádio, Vargas anuncia uma nova constituição, que ele chama de Estado Novo.

\begin{abstract}
Getúlio Vargas era o ditador menos carismático de então. Ele não tinha o encanto agitado de seu equivalente argentino Juan Perón e nunca cultivou a aparência pessoal melodramática de um Hitler ou de um Mussolini. Pouco atraente, suas principais características físicas eram a barriga e um sorriso irônico habitual. Mas ele usava sua persona pouco expressiva de modo vantajoso, pois combinava-a com uma excepcional habilidade para avaliar outras pessoas e induzir seus inimigos a subestimá-lo. Era um admirável ouvinte e tinha habilidade de convencer a maioria de seus interlocutores, quaisquer que fossem suas posições, de que ele autenticamente os compreendia ou mesmo de que concordava com eles. (SKIDMORE, p.163)
\end{abstract}

Vargas governava desde a década de 1930 e tinha uma visão clara de como o Brasil deveria se desenvolver em termos econômicos, políticos e sociais. Ele tinha um projeto de poder e para o desenvolvimento do país, com base em um governo central forte, ideia que era plenamente aceita pelos militares que se identificavam e davam respaldo ao projeto.

\begin{abstract}
Se a construção do sistema ideal está ligada às realizações econômicas e administrativas, e se é preciso destruir toda uma tradição política, passada, o Estado Novo, por sua vez, é obrigado a criar toda uma nova sistemática que, do ponto de vista político, é a idealização de uma escala de valores e obrigações, que começa com a imposição da Autoridade do chefe da Nação e acaba, em última escala, no Povo. Os dois extremos existem para se completar e um funciona em benefício do outro. (CARONE, 1977, p.162-163)
\end{abstract}

Continuando, Carone entende que o Estado Novo, diferentemente dos regimes congêneres fascistas europeus, não adota uma construção ideológica centrada em dogmas e caracteres místicos. Vargas construiu um discurso sustentado no argumento de que o Estado Novo seria o regime ideal para o país, por ser capaz de promover a paz social e conduzir uma ação política construtiva, em oposição à forma republicana democrática que vigorava até então. Criticava também o regime eleitoral, que qualificava como inadequados os partidos políticos, pois na sua 
avaliação eram movidos por interesses pessoais e as doutrinas contrárias aos postulados do novo regime.

Para Vargas o país precisava claramente de um planejamento que contemplasse um processo de investimento crescente, em diversas áreas, como a educação e de uma economia calcada em um projeto de industrialização crescente, aliada a uma estratégia de longo prazo, visando uma maior inserção do país no plano internacional. Uma parte do projeto de modernização do Estado brasileiro já havia sido colocada em curso no governo provisório, quando Vargas cria a primeira legislação trabalhista e social, que criava uma rede de proteção ao trabalhador, mas que era também um arcabouço de controle social.

A estrutura da legislação trabalhista que aparece no governo Vargas, incluindo a Consolidação das Leis do Trabalho (CLT), que é assinada em 1942, procurava estabelecer um conjunto de direitos fundamentais do trabalho que, combinados o controle sindical, a manipulação e a repressão vão, a médio e longo prazo, ajudar a construir junto à classe trabalhadora uma base de apoio e sustentação política para Vargas que mais adiante, em 1950, o colocará pela segunda vez no poder.

Outra decisão vinculada ao projeto de modernização do Estado foi a criação do Departamento Administrativo do Serviço Público (DASP), que tinha entre suas atribuições capacitar servidores e futuros servidores públicos. A centralização do funcionamento da estrutura do Estado era amparada em dois pontos: nos militares, que davam suporte à estabilidade do governo e nos tecnocratas, que geriam a administração de maneira integrada. O corporativismo foi a opção de Vargas e seus colaboradores. Segundo Skidmore (2003, p.165):

A intenção do corporativismo era facilitar a adoção do capitalismo moderno ao mesmo tempo que evitava os extremos da permissividade do laissez-faire, por um lado, ou da direção total do Estado, por outro. A ideia era estabelecer entidades associadas separadas (corporações), cada uma representando setores econômicos específicos.

E mais:

A idéia era estabelecer entidades associadas separadas (corporações), cada uma representando setores econômicos específicos. Empregadores e empregados de cada setor tinham suas próprias corporações, por exemplo. A coordenação das relações entre essas entidades associadas era responsabilidade do governo nacional, eliminando conflitos entre corporações concorrentes e deixando a última palavra (sobre salários, benefícios, condições de trabalho) ao governo central. 
Os países europeus começavam a sucumbir ao fascismo que parecia aos olhos de muitos uma solução para tempos econômicos e sociais conturbados. Os discursos do expansionismo alemão produziam um clima de apreensão e pairavam nas cabeças das pessoas suspeitas do surgimento de um novo conflito armado em solo europeu. A ameaça de uma nova guerra rondava o mundo.

A Alemanha sob o governo dos nazistas e de Hitler havia se recuperado economicamente, o seu parque industrial destruído pela inflação da época da República de Weimar ${ }^{4}$ fora reconstruído. O mundo acompanhava o despontar de uma sociedade forte, militarmente reequipada e com sonhos expansionistas.

Apesar de sua extensão territorial, o Brasil não era um país de grande expressão internacional, ficando atrás, na América do Sul, da Argentina, naquela época um país mais rico e mais desenvolvido no aspecto cultural e educacional e que, em certos aspectos, com um modo de vida que se assemelhava ao padrão de cidades europeias mais desenvolvidas.

Getúlio Vargas cogitou estabelecer laços militares com os Estados Unidos, sem sucesso, talvez porque o governo americano não quisesse parecer que se preparava para entrar na guerra. As recusas fizeram com que o governo brasileiro mantivesse uma posição neutra com relação ao conflito, pelo menos no seu início e, paralelamente, continuava a cultivar um bom relacionamento diplomático e comercial com a Alemanha. A eficiência germânica era admirada governo brasileiro, enquanto que as nações democráticas eram vistas com certa reserva. O Brasil, no período entre 1933 e 1938, tinha uma parceria comercial significativa com a Alemanha, exportando algodão brasileiro e recebendo em troca produtos industrializados alemães.

Com a II Guerra Mundial em andamento, os Estados Unidos liderando as forças do eixo (Alemanha, Japão e Itália), a Alemanha já chegando a Moscou e os submarinos alemães patrulhando o Atlântico e bombardeando os comboios americanos que abasteciam a Inglaterra, os norte-americanos passam a se interessar pelo que o Brasil poderia lhes oferecer como, por exemplo, suas bases aéreas e marítimas, que ficavam em ponto estratégicos do Oceano Atlântico, que antes foram recusadas. Vargas então utiliza seu apoio para, em troca, conseguir para o Brasil equipamento militar, assistência técnica e financiamento para a construção de uma usina

\footnotetext{
${ }^{4}$ Instaurada na Alemanha, em 1918, logo após a I Guerra Mundial e logo que o país começou a ser controlado pelos militares após a fuga do Kaiser Wilhelm II. Em 28 de Outubro desse mesmo ano, a Alemanha apresenta sua nova Constituição, que transforma o Reich numa república parlamentar, na qual o Chanceler estava subordinado ao Reichstag (Parlamento Alemão) e não mais ao imperador.
} 
siderúrgica, a Companhia Siderúrgica Nacional (CSN) de Volta Redonda, uma decisão estratégica e um dos pilares para o processo de industrialização, que vai chegar ao seu ápice treze anos depois, no governo de Juscelino Kubitschek.

É entre 1939 a 1941 que o regime endurece. Em 1942, o Estado Novo adota uma nova postura em razão da II Guerra Mundial, visto que o governo brasileiro já não podia manter uma posição indefinida perante o conflito. Foi nesse ano que o Brasil teve que ceder à pressão americana, autorizando a instalação de suas bases militares no nordeste brasileiro. Esse alinhamento do Brasil com os EUA indica que haveria a continuidade do projeto autoritário em curso no Estado Novo, embora os próprios líderes desse governo não acreditassem na possibilidade de se manter, ao final do conflito, um governo antiliberal e nacionalista, sustentado pela desmobilização como estratégia política.

Por conseguinte, o problema que se colocava para as elites era como transitar do autoritarismo para a liberal-democracia, elaborando uma estratégia que possibilitasse sua permanência do poder. Ou seja, uma transição "por dentro", concebida e implementada pela elite intelectual e política do próprio Estado Novo. (GOMES, 2010, p.58)

A entrada dos Estados Unidos no Brasil também se deu pela cultura. O governo americano destaca o multimilionário Nelson Rockefeller para cuidar da ampliação das relações culturais com a América Latina, mas que tinha o Brasil como principal foco. Nesse período foram produzidos filmes para construir uma opinião favorável aos americanos. Orson Welles e Walt Disney foram uns dos que colaboraram com o projeto, sendo inesquecível a vinda ao Brasil do Pato Donald, personagem criado por Disney, para conhecer seu companheiro brasileiro, o Zé Carioca, um papagaio que fazia muito sucesso no país.

As eleições previstas pelo calendário eleitoral de 1938 foram abortadas pela ditadura do Estado Novo, que propõe marcar novas eleições presidenciais para 1943. Porém, a guerra passa ser uma desculpa para novo adiamento, com Getúlio anunciando que "emergência da época de guerra não permitiria a incerteza de uma eleição presidencial", deixando o pleito eleitoral para "até depois da guerra". (Skidmore, 2003, p.175) Como era costume, Getúlio, como todos os políticos e lideres populistas do período, jogava com as situações e com a ambiguidade dos seus atos, deixando pairando no ar um cenário de incerteza sobre os rumos da política e, por conseguinte, os do país.

Em meados de 1945 surgem novos partidos políticos, como a União Democrática 
Nacional (UDN), formada por liberais, pessoas da classe média e alta e de oficiais do Exército, opositores de Getúlio, mas que viria a ser a base de sustentação política deste no futuro, o Partido Social Democrático (PSD) ligado aos caciques políticos regionais e o Partido Trabalhista Brasileiro (PTB), que representava os trabalhadores urbanos.

No mesmo ano, frente à ambiguidade de Vargas e a incerteza de novas eleições, acontece um movimento denominado "Queremismo", promovido por líderes sindicais e pelo Partido Comunista, que defendia a permanência de Getúlio no poder, e que tinha um slogan, "Queremos Getúlio", por isso o nome do movimento. Do outro lado, o embaixador norte-americano Adolph Berle sugeriu publicamente a renúncia de Getúlio. Diante da indefinição da situação, o general Góes Monteiro e outros generais do Exército ligados à região do Rio de Janeiro, influenciados pela UDN, mostravam-se preocupados. Vargas então recebe um ultimato para comunicar sua renúncia ou a situação se agravaria.

Os militares brasileiros praticamente depuseram Getúlio Vargas, talvez inspirados pela ação dos militares argentinos, que haviam colocado em prisão domiciliar o coronel Juan Domingo Perón, presidente do país e também uma liderança carismática muito popular, era vista pelas Forças Armadas como uma ameaça que poderia influenciar e manipular os rumos do país. Na avaliação dos militares brasileiros, se Vargas fosse recolocado no governo com o apoio dos trabalhadores urbanos, isso poderia ocasionar a perda do controle social e da ordem estabelecida, levando o país para o que se chamava de "República Sindicalista", que deveria ser evitada a qualquer custo.

De uma maneira ou de outra, os militares sempre atuaram para garantir a governabilidade do país, algumas vezes chamados pelo poder civil para recompor a ruptura da ordem constitucional e, no caso de Vargas, conseguindo uma deposição negociada, depois de sua permanência por quinze anos no poder. Assim, depois de nove anos, já no ano de 1946, acontece no Brasil eleições para os cargos majoritários. Para a Presidência da República concorriam Eduardo Gomes, pela UDN, e o brigadeiro da Aeronáutica Eurico Gaspar Dutra, pelo PSD, que tinha sido Ministro da Guerra de 1936 a 1945 no Estado Novo, ambos egressos da ativa.

A vitória de Dutra representou uma reacomodação das forças políticas. O principal destaque do Congresso foi discutir e aprovar uma nova Constituição, promulgada em 1946, que buscava restaurar o poder de estados e municípios e também do Congresso. 
Voltado para um projeto de renovação constitucional, pouco a pouco vai-se percebendo o seu caráter conservador, a permanência de privilégios jurídicos e pequenas conquistas com relação aos direitos constitucionais anteriores. É verdade que o que aparece como positivo é a esperança de um regime aberto, de tendência democrática, onde a afirmação de eleições, dos direitos humanos e de outras conquistas se projeta como fundamental para as gerações que viveram as privações dos anos de ditadura. (CARONE, 1985a, p.19)

O Brasil, mesmo com os avanços no seu processo de industrialização, ainda apresentava um longo caminho a percorrer no aspecto do desenvolvimento econômico:

\begin{abstract}
Ainda que a base eleitoral em 1945 fosse bem maior do que em 1930, socioeconomicamente o Brasil era ainda, na expressão da época, um país "atrasado". Sua indústria limitava-se a poucas cidades grandes, doenças crônicas eram comuns e cuidado médico regular era inexistente para a maioria da população. A expectativa de vida geral era de 46 anos, diminuindo para 40 no nordeste. A economia continuava a depender das exportações de café. (SKIDMORE, 2003, p.183)
\end{abstract}

Se no plano político o governo Dutra teve uma transição tranquila, fazendo o país passar de uma ditadura para um regime democrático, inclusive com a promulgação da Constituição de 1946, o planejamento econômico cometeu alguns equívocos, principalmente ao retomar algumas práticas do pensamento liberal, optando pelo estímulo à venda de produtos primários, como o café, considerada uma estratégia superada, ao invés de usar parte das reservas cambiais para dar continuidade ao processo de industrialização do país, reforçado por Vargas com a construção da CSN.

Ao invés disso, o governo preferiu utilizar as reservas cambiais, que foram consumidas em pouco tempo, para a importação maciça de diversos produtos e a compra e a incorporação de diversas empresas estrangeiras que atuavam no Brasil, principalmente as que atuavam nos setores essenciais, como de energia. $O$ comprometimento das finanças fez a situação econômica se agravar e obrigou o governo a adotar uma política de fomento à exportação, buscando assim trazer, cada vez mais, divisas para o país. Em pouco tempo essa decisão vai ter como reflexo um conflito entre empregadores e trabalhadores, por conta das reivindicações salariais.

Quando deixou a presidência da República em 1945, deposto pelos militares, Vargas conseguiu manter vínculos com os diversos setores tradicionais do poder, graças a 
sua atuação política como Senador eleito pelo Rio Grande do Sul e São Paulo e deputado por mais sete estados. Aos poucos, ele foi transformando sua imagem de ditador para a de um político democrata, apesar de ainda continuar a receber críticas de grupos que foram prejudicados pela ditadura do Estado Novo, e aos poucos vai pavimentando o caminho para a sua candidatura à presidência da República, nas eleições que aconteceriam em 1950.

Sua estratégia para obter êxito consistiu em conseguir o apoio dos grupos políticos mais poderosos e do general Góes Monteiro, para que o Exército não se posicionasse contrário à sua candidatura, uma vez que em 1945 ele fora deposto pelos militares. O mais importante apoio para sua candidatura foi recebido do PTB, partido que representava o movimento dos trabalhadores, mas Getúlio também procurou ligar-se a outros partidos, cortejando os lideres regionais.

\begin{abstract}
Com Getúlio Vargas vai-se dar situação diferente, pois, passados os anos, ele não se vê ainda livre da pecha de ditador, e os rancores anteriores contra a sua pessoa são realimentados constantemente pelas UDN's. Além desse aspecto, o combate ao getulismo mascara a luta contra as reivindicações do operariado - tema que serve de elo de união entre as classes dirigentes e os grupos direitistas do Exército. Por estas e outras razões, Getúlio Vargas não consegue unir em torno de si, como seu antecessor, a totalidade dos grupos políticos dominantes, nem as classes produtoras, e, ainda menos, as facções mais radicais de direita do Exército. Ele conta unicamente com a simpatia popular - de caráter difuso - com o apoio do PSD e do PTB, além dos grupos nacionalistas do Exército. (CARONE, 1985a, p.42-43)
\end{abstract}

Eleito, Getúlio retoma a plataforma de desenvolvimento do país, diferentemente do seu antecessor, Eurico Gaspar Dutra, que tinha adotado uma posição mais liberal. Vargas entendia que precisaria promover um processo de industrialização mais amplo e para isso sua primeira iniciativa foi a criação, em 1952, do Banco Nacional para o Desenvolvimento (BNDE), valendo-se dos dados do trabalho da Comissão Mista EUA-Brasil para o Desenvolvimento Econômico (1951-1953), composta por especialistas dos dois países, que realizou um real diagnóstico das necessidades do Brasil.

Como o suprimento de energia era perenemente inadequado para sustentar a industrialização (a preocupação do governo com esse assunto remontava a 1938), o governo propôs criar empresas estatais de petróleo e eletricidade. Tais medidas violavam o preconceito liberal contra a intervenção do Estado na economia e provocaram duras críticas dos políticos da UDN e dos economistas ortodoxos. O presidente defendeu suas medidas invocando patriotismo, 
nacionalismo e realismo em face de uma economia mundial em transformação - apostando que seu apelo nacionalista superaria o consenso da elite favorável ao liberalismo econômico. (SKIDMORE, 2003, p.189)

A linha mestra desse governo Vargas foi a implementação de um projeto desenvolvimentista, centrado na forte presença do Estado em áreas consideradas estratégicas para o desenvolvimento do país, a partir da consolidação efetiva de uma indústria de base - petroquímica, siderurgia, energia e transportes - procurando assim estimular a industrialização e a modernização do país, mas que, incoerentemente, acaba por levá-lo a um conflito permanente com a oposição, que passa a atuar na Câmara e no Senado Federal para a não aprovação de seus projetos.

Essa oposição tinha uma explicação. Ao apoiar o fortalecimento de uma indústria nacional, inclusive com a entrada de empresas estatais, Vargas contrariava frontalmente os interesses dos investidores e das empresas estrangeiras, de muitos economistas e da UDN, que tinha sua plataforma política focada na doutrina do liberalismo tradicional, que era totalmente contrária a qualquer intervenção do Estado na economia. Os grupos mais conservadores insistiam numa linha de liberalismo econômico, que favorecia nitidamente o capital internacional e diretamente as grandes economias europeia e norte-americana, em detrimento da construção de um parque industrial nacional.

Nesse sentido Vargas foi ousado em romper este modelo tradicional, exportador de matéria-prima e importador maciço de bens industrializados, para lançar as bases do desenvolvimentismo que permitiria ao Brasil mudar de patamar político e econômico em menos de duas décadas. O governo, porém, tinha muita dificuldade para obter a aprovação no Congresso Nacional de projetos de lei que fossem efetivamente de interesse do país e tinha que enfrentar crises constantes, ataques da oposição veiculados nos jornais e no rádio.

Entre as propostas apresentadas para aprovação e que suscitou grandes debates e polêmicas, sendo combatida pela UDN contrária a qualquer monopólio estatal, estava a criação de uma empresa estatal de petróleo, a Petróleo Brasileiro (Petrobras), em 1951. Ao contrário dos udenistas, a esquerda e o PCB diziam que a nova empresa deveria ser um monopólio estatal completo, pois tinham sérias desconfianças com relação às empresas petrolíferas internacionais, inclusive denunciando aqueles parlamentares que recebiam para defender os interesses de tais empresas.

Mas havia também, entre os militares, divergências sobre o assunto. Alguns apoiavam 
a ideia da criação da empresa dentro de uma perspectiva nacionalista, entendendo que os benefícios de o país ser autossuficiente na questão do petróleo, enquanto outros, anticomunistas, desconfiavam da proposta, pois viam na intervenção estatal um caminho rumo ao comunismo.

Assim, essa polêmica acerca da Petrobras e o desejo de Vargas de modernizar o país e buscar autossuficiência em determinados setores estratégicos só faziam aumentar a polarização política com a UDN. Em paralelo, o Brasil se vê em meio a uma grave crise econômica por conta da queda vertiginosa do preço do café em 1953 e da redução violenta das suas receitas cambiais, que acabaram por gerar uma diminuição no balanço de pagamentos, obrigando o país a recorrer à ajuda do Fundo Monetário Internacional (FMI).

Diante deste quadro Vargas acaba por ser impelido a colocar em prática um programa de reformas econômicas, começando pela desvalorização cambial, com o objetivo de incentivar a substituição das importações pela fabricação de produtos fabricados pela indústria nacional, de modo a obter um melhor equilíbrio das contas externas. Porém, essa medida e o aumento da inflação vêm acompanhados de outras medidas consideradas bastante impopulares, como restrições ao crédito e o arrocho salarial, que afetavam diretamente a classe trabalhadora e prejudicavam o crescimento econômico. Ainda assim, Vargas vai aumentar o valor do salário mínimo ${ }^{5}$ tentando preservar o poder de compra das classes trabalhadoras, uma decisão que vai comprometer a capacidade do Estado de responder adequadamente às demandas populares.

Apesar das concessões feitas pelo governo visando favorecer os segmentos sociais mais pobres, a situação econômica e social somente se agravava e aumentava a radicalização dos movimentos populares que reivindicavam seus direitos sociais através de protestos e greves trabalhistas, levando às classes dominantes ficarem temerosas com o avanço dos movimentos populares, que passam então a discordar do modo como o governo respondeu às exigências e demandas sociais. Esses e outros episódios vão desencadear o início do fim de Vargas.

A falta de uma base de sustentação partidária sólida no Congresso Nacional e o fato de não reunir as mesmas condições políticas de governabilidade como a que possuía no seu governo anterior, uma conjuntura agravada pela crise econômica e por uma

\footnotetext{
5 Em fevereiro de 1954 foi tornado público um documento que ficou conhecido como "Manifesto dos Coronéis", assinado por 81 oficiais superiores do Exército, muitos deles ligados à Cruzada Democrática. O documento, que foi enviado ao ministro da Guerra, protestava contra a falta de recursos para o Exército e contra a proposta do governo de dobrar o valor do salário mínimo, apresentada pelo Ministro do Trabalho, João Goulart.
} 
oposição cada vez mais ferrenha a seu governo, liderada pela UDN, por Carlos Lacerda e por certos segmentos militares, que utilizava uma estratégia de intimidação mesclada com a difamação da pessoa do presidente, acabaram por criar um cenário de instabilidade política e de crise de governabilidade.

Carlos Lacerda fazia uma oposição pesada ao governo, publicando artigos em seu jornal Tribuna de Imprensa, com teor ofensivo e difamatório e ataques violentos contra Vargas, tentando convencer a opinião pública de que havia muita corrupção em torno do presidente e que ele não tinha mais controle da situação.

Os dias de Getúlio Vargas como presidente estavam claramente contados. Se ele não renunciasse, um golpe militar seria inevitável. Mas se renunciasse estaria abandonando a imagem há muito cultivada de si mesmo como um líder sinceramente dedicado ao bem-estar dos pobres, a ponto de se descrever como um mártir enfrentando forças poderosas e egoístas, tanto nacionais quanto estrangeiras. (SKIDMORE, 2003, p.194)

O episódio conhecido como o Atentado da Rua Tonelero, uma tentativa de assassinar o jornalista e político Carlos Lacerda, foi o responsável por desencadear a crise final do governo Vargas, depois que se descobriu que o atentado fora feito por Gregório Fortunato, pessoa de confiança da guarda pessoal do presidente. Os ânimos se acirram, a oposição exige o afastamento de Vargas da presidência e aumenta a pressão das forças armadas para que isso aconteça.

Depois de receber, pelas mãos do seu Ministro da Guerra, Zenóbio da Costa, um documento que trazia o ultimato dos generais e ciente que estava da gravidade da situação, pois sabia que seu afastamento do governo era na verdade sua deposição, Vargas redige, como seu último ato, uma carta-testamento e se suicida com um tiro no peito, um fato que causou grande comoção popular, levando o povo às ruas em diversas cidades do país, para prestar homenagens de apoio ao ex-presidente.

Com seu suicídio, Getúlio virou o feitiço contra o feiticeiro contra seus inimigos da UDN e militares. Ele havia neutralizado o que eles planejaram ser uma esmagadora vitória política, pois não queriam apenas a remoção de Getúlio, mas também a reversão de sua política e o desmantelamento de sua rede política. Essa agenda era agora impossível, dado o estado da opinião publica. Getulio podia estar morto, mas sua influência estava bem viva. (SKIDMORE, 2003, p.194195)

A morte de Vargas marcou definitivamente sua passagem pela história do país, pois conseguiu, através do seu populismo, se marcar como um dos lideres mais adorado da história republicana, deixando como legado um processo definitivo de 
industrialização, que vai ser ampliado pelo seu sucessor. É importante destacar que o segundo governo de Vargas - e de seus sucessores, Juscelino Kubitschek (19561960), Jânio Quadros (1960) e João Goulart (1960-1963), tem como marca o caráter populista de suas ações, ou seja, tinha uma prática política de estabelecer uma relação direta com as massas, um vínculo emocional e não racional com o povo, obtido por meio de métodos de aliciamento (concessões) das classes sociais menos favorecidas e também das classes médias, como forma de angariar votos e prestígio através da simpatia que tinham por ele.

Por isso a importância de se reconhecer a relevância que teve o primeiro governo de Getúlio Vargas (Era Vargas) no âmbito político, cultural, social e econômico, mesmo considerando suas ambiguidades. Estudos recentes indicam que os reflexos do período conhecido como Estado Novo (1937-1945) podem ser sentidos até hoje. Segundo Angela de Castro Gomes (2012, p.37), o desafio é entender o "conjunto diversificado de políticas, muitas vezes contraditórias e ambíguas, que convivem e disputam espaço em um contexto nacional e internacional extremamente conturbado, marcado pela eclosão da II Guerra Mundial".

\footnotetext{
René Gertz entende que os historiadores têm, na verdade, dificuldades para estudar o período pela ambiguidade de suas políticas e também pela marca fascista do regime. Muitos historiadores não conseguiram escapar da ambivalência, pois, embora o Estado Novo fosse uma ditadura e apresentasse características fascistas, ele apresentou avanços econômicos e sociais. (1991, p.111-131)
}

Vargas, como presidente no período de 1930-1934, desenvolve amplo projeto de modernização do Estado, visando uma integração nacional através de um processo industrial de longo prazo, de modo a constituir um mercado efetivo que assegurasse uma nova etapa de desenvolvimento, pois, se nos anos 1920 o café se consolidou como o maior produto na pauta de exportações brasileiras, esse quadro mudou radicalmente depois de 1929, quando aconteceu a quebra da Bolsa de Valores de Nova Iorque, sinalizando o fim desse ciclo.

O Estado Novo, tido como uma esperança de renovação, por isso o seu nome, tem início em 1937, a partir de um golpe e termina em 1947 com a deposição de Vargas. O golpe minuciosamente planejado, que fazia parte de um novo projeto político das elites, teve a participação de civis e militares e marca o início de uma ditadura, comandada por um civil e apoiada pelas Forças Armadas, em especial o Exército. Segundo Gomes, um "golpe silencioso", sem protestos, sem reações contrárias, um silêncio que 
[...] evidencia não apenas o poder político dos que então ascendiam à direção do Estado, mas também a existência de uma proposta de construção de imagem: para o presente que se inaugurava e, em decorrência, para seu "passado e futuro". (2010, p.38)

Denis Rolland (2003, p.86) considera que não havia no Estado Novo um poder considerado como civil, mesmo o sendo o próprio presidente, pois o regime tinha como sua essência a "militarização do Estado" e nem tampouco considerado um poder militar, já que o próprio Exército estava integrado à Nação.

Por ser uma esperança de transformação, de renovação, o Estado Novo era relacionado à Revolução de 1930, que também tinha uma proposta de romper com o passado, sendo "a" conclusão lógica do movimento revolucionário de 1930 que não só enterra definitivamente a República Velha como faz com que os anos que o precederam transformem-se na antecâmara de sua presença inevitável. (GOMES, 2010, p.39)

A Revolução de 1930 seria, então, um marco em nossa história, um rompimento com os erros da Primeira República ou República Velha, oligárquica, fraca e liberal e o Estado Novo, a confirmação dos anseios dessa Revolução, que "sepultara um simulacro de República, ensaiada e fracassada praticamente desde seu começo, em 1889". (GOMES, 2010, p.38)

A visão de Vargas se colocava no sentido de se encontrar novas formas de obtenção de produtos, de modo a diversificar a pauta de exportação do Brasil, de modernização das relações trabalhistas e sociais, onde o Estado ocuparia o papel de mediador nas principais questões e demandas do plano social e político.

Segundo Falcão (1984, p.27), a substituição do ciclo rural pelo ciclo urbano e a ampliação da cidadania ampliam a base social do poder político do governo Vargas, de modo a possibilitar a organização e o controle da participação no Estado e na sociedade, de um grande contingente de cidadãos antes excluídos da vida nacional. Por outro lado, passava a reconhecer as entidades representativas que antes estavam livres da influência estatal, como os sindicatos dos trabalhadores, o patronal, as atividades estudantis e culturais.

Vargas dizia que seu governo era um governo democrata, que atendia aos interesses do povo, que tinha sua participação mediada por organizações sindicais e outras associações, que tinham seus representantes escolhidos e nomeados pelo próprio governo, ou seja, o Estado Novo, apesar de ter como uma de suas premissas colocar ordem e trazer o progresso ao país, era na verdade um Estado autoritário e centralizador. 
A ruptura com o antigo, com o "velho" da República, passava pelo entendimento de que não havia mais possibilidade de se manter o modelo liberal no Estado brasileiro em razão da própria trajetória histórica do país, do esgotamento do modelo depois da crise de 1929 e também porque a busca por uma sociedade moderna passava por reformas nas instituições políticas. Já na Primeira República havia uma corrente nos meios político e intelectual que aprovava a ideia de ampliar o poder de intervenção do Estado.

Além do cenário internacional, também a política nacional influencia as mudanças que acontecem no Estado Novo e é então que surge um novo pacto político entre o Estado e a classe trabalhadora brasileira, redefinindo a relação entre Estado e sociedade e o papel de protagonismo dos trabalhadores no ambiente político.

Como havia uma forte intervenção do Estado na organização dos trabalhadores, descaracterizando o processo iniciado na Primeira República, havia a necessidade de se ampliar a discussão desse novo pacto, inclusive porque a interferência governamental na organização dos trabalhadores estava calcada na lógica da troca, ou seja, o Estado oferecia benefícios materiais, ou melhor, as leis sociais do trabalho, e em troca recebia obediência política. Os trabalhadores, por outro lado, aderiam ao regime com vistas a novos direitos sociais e acabavam manipulados pelo Estado, seduzidos que estavam pelos discursos e pelas leis que mais ficavam nas promessas.

Mas não podemos subestimar a capacidade dos trabalhadores de participar dessa lógica populista de maneira ingênua e nem superestimar a capacidade do Estado de submeter os mesmos. A classe trabalhadora viu que, aderindo à política populista, poderia alcançar direitos sociais e trabalhistas em um período em que os direitos políticos e civis estavam suspensos. Esse quadro pode nos levar a entender que havia no Brasil dos anos 1930 e 1940 tanto uma classe trabalhadora desmobilizada e acomodada como também uma classe ativa e politizada, mas que aceitava o domínio do Estado sobre ela. Gomes $(2010$, p.59, 61) propõe a "designação de pacto político trabalhista para entender as relações construídas pelo Estado e pela classe trabalhadora no Brasil, nesse período".

Segundo a historiadora, havia nesse pacto uma dimensão simbólica e outra organizacional. No plano simbólico via-se um discurso construído para a divulgação do Regime, que marca nossa política até hoje, que não se pautava apenas nas questões de ocasião, mas era um discurso que pretendia deixar marcada sua existência e as condições de sua criação. No plano organizacional, o pacto era 
sustentado pelo modelo corporativo sindical e pelo sistema político e partidário.

A autora entende que a utilização do conceito "populismo", sob a ótica das relações sociais, apresenta problemas, pois indica uma dimensão de manipulação que o Estado exercia sobre as massas, mesmo reconhecendo a ambiguidade existente nessa relação, ou seja, reconhecendo que entre os trabalhadores e o Estado existia um diálogo, mesmo que com pesos diferentes.

Tal operação afastava a dicotomia, muito vigente, entre autonomia e heteronomia da classe trabalhadora, como forma de designar e explicar a ausência de lideranças "verdadeiras" e de sua "falta de consciência" ou sua "consciência possível". (GOMES, 2010, p.60-61)

Naquela época acontecia (como até hoje acontece) de se tornarem suspeitos todos os que mantivessem um relacionamento com as lideranças políticas, pois estes acabavam sendo vistos como desleais por estarem associados a elas, perdendo assim seu poder de negociação.

É importante destacar que nos discursos do governo Vargas não eram lembradas as lutas dos trabalhadores na busca pelos seus direitos, incutindo neles a ideia de que seus benefícios foram conseguidos sem que tivessem sido reivindicados, como se fosse uma dádiva, também conhecida como a ideologia da outorga, tornando o discurso um instrumento de poder, muito utilizado no Estado Novo.

Esse formato de discurso, que ao mesmo tempo mobilizava e retirava toda a força histórica das conquistas, colaborou com o sucesso do Estado Novo que figurava como o governo que antecipava os benefícios trabalhistas, uma dádiva, portanto, que deveria ser agradecida. Isso seria mais que uma manipulação, é a própria ideologia do direito social como dádiva, como bem exprime Angela de Castro Gomes:

\footnotetext{
Uma lógica que combina crenças e interesses, tanto por parte dos dominantes quanto dos dominados, embora com evidente desequilíbrio de poder entre eles. Neste contexto, pode-se entender o esforço do Estado Novo na divulgação dos direitos trabalhistas, recorrendo aos mais modernos meios de comunicação da época, bem como usando recursos humanos altamente qualificados. (2010, p.63-64)
}

Nos anos 1970 e 1980 a crítica ao Estado Novo era muito disseminada e através dela se pretendia atingir o Regime militar vigente. Porém, era difícil manter as críticas sobre o viés autoritário do Estado Novo, considerando os seus feitos no campo dos direitos sociais. As incongruências do Regime interferiam nos estudos sobre ele, pela dificuldade de se aliar a crítica ao autoritarismo, a uma dimensão 
mais empreendedora dos anos Vargas. Há um certo risco de se reconhecer as ações de um governo ditatorial voltadas à modernização do país, no âmbito social e econômico, sem parecer que se apoia o seu lado autoritário.

\begin{abstract}
Mesmo autores que procuram ser neutros ou críticos não conseguem escapar da ambivalência. O Estado Novo foi uma ditadura, teve traços fascistas, mas muitos autores não conseguem negar avanços na economia, na construção do Estado, na questão social. (GERTZ, 1991, p.112)
\end{abstract}

O Estado Novo dizia-se a coroação ou a concretização dos ideais da revolução de 1930 e vários historiólogos se sentem forçados a admitir que isto é verdade. O Estado Novo também afirmava ser autoritário, mas não fascista ou totalitário (mesmo entre seus idealizadores, a palavra fascista era rejeitada). Analistas modernos admitem que isto é verdade. Como muitos pesquisadores "têm medo de parecer como mancomunados com o poder, procuram temas menos comprometedores". (GERTZ, 1991, p.113)

Podemos considerar que os debates sobre o Estado Novo, presentes nos anos 1970 e 1980, tiveram como resultado positivo o fato de terem explorado mais a fundo a questão do autoritarismo no Brasil, optando pelo abandono da designação Estado fascista e totalitário, substituindo-a por Estado Autoritário. Também foram desenvolvidas análises das "formulações doutrinárias" e das políticas públicas do Estado Novo, "retomando a participação de atores (coletivos e individuais) como burocracia, os intelectuais, os industriais, os banqueiros, os sindicalistas, etc." nesse governo. Segundo Angela de Castro Gomes:

Tais estudos cada vez mais concluíam que não ocorrera, no caso
brasileiro, um monopólio absoluto do Estado no plano jurídico- político,
continuando a existir muitas tensões e oposições, até no interior do
núcleo dirigente estado-novista, mesmo que limitadas de múltiplas
formas. Assim, se era possível identificar traços totalitários no Estado
Novo, não era adequado designá-lo como um Estado fascista.
(2010, p.54-55)

Mesmo suprimindo direitos políticos, tendo praticado restrições à cidadania e à cidadania política, o Estado Novo deixou marcas profundas na história brasileira, tendo em vista a modernização implementada na área da administração pública que teve resultados tanto na área econômica como na social. 


\subsubsection{A cultura e o Regime}

Depois de 1930, a cultura brasileira passa a ter um papel importante na vida do país e a ser um elemento relevante da política. Havia um pensamento político predominante de que a elite seria a responsável pelas mudanças sociais que o Brasil tanto necessitava, já que o povo estava despreparado para estar à frente de um projeto de reconstrução nacional. O caminho seria então a difusão da cultura.

Já havia um movimento que rechaçava a produção artística dos anos 1920, muito voltada à imitação, que propunha uma volta às raízes da cultura brasileira. Artistas e intelectuais brasileiros buscam conhecer melhor o Brasil, como o movimento modernista, presente na literatura e na pintura. Pensadores procuravam dar novas interpretações à nossa realidade.

Assim, elementos modernos e tradicionais se fundem na nova maneira de organização da cultura, a qual pressupõe papel especial a ser desempenhado pelos intelectuais: serão agentes do processo de transformação da sociedade e constituir-se-ão em força política de importância desse processo. (BASTOS, 2003, p.155)

Atento a essa grande movimentação artística e intelectual Vargas vai dar início a várias ações na área cultural e também mobilizar os meios de comunicação para promover as ações do regime.

\footnotetext{
Processo que adquire forma moderna com a Revolução de 30 , e é determinado por fatores estruturais tais como a substituição do ciclo rural e oligárquico pelo ciclo urbano e industrial, a consequente ampliação social da cidadania, pelo aumento da oferta de empregos urbanos, e a crise econômica internacional, ao provocar a guerra e a afrouxar os laços de dependência política e cultural que vinculavam o Brasil à Europa. (FALCÃO, 1984, p.26-27)
}

$\mathrm{Na}$ cultura, o Estado amplia sua presença com a criação de novas instituições, universidades, o Instituto Nacional do Livro (INL), o Museu Nacional de Belas Artes, o Serviço Nacional de Teatro (SNT), o Instituto do Patrimônio Histórico e Artístico Nacional (IPHAN), e também o apoio à atividade individual de artistas e intelectuais como Portinari e Villa Lobos, que têm no Estado um mecenas, tudo fazendo parte de um grande projeto que unificava educação e cultura.

Vale destacar aqui a criação do IPHAN, em 13 de janeiro de 1937, pela Lei n. 378. Já havia em 1936 uma preocupação do então Ministro da Educação e Saúde, 
Gustavo Capanema, com a preservação do patrimônio cultural brasileiro, que pede a Mário de Andrade que elaborasse um anteprojeto de Lei para a proteção desses bens.

A atividade do IPHAN vinha ao encontro dos projetos do Estado Novo e deveria transpor três desafios: primeiro o desafio político de estimular e canalizar a participação social na preservação cultural; segundo o desafio ideológico de identificar e forjar um "patrimônio cultural brasileiro" (diferenciado em relação às experiências europeias e norte-americanas, e ao mesmo tempo representativo da complexidade e heterogeneidade da cultura brasileira); e, finalmente, o terceiro e último desafio, o administrativo, de cunhar e consolidar uma estrutura estatal burocrático cultural, nacional e eficiente. (FALCÃO, 1984, p.27)

O Decreto-lei n. 25, de 30 de novembro de 1937 que organiza a "proteção do patrimônio histórico e artístico nacional", ficou muito aquém do projeto pensado por Mário de Andrade, apesar de ambos limitarem o direito à propriedade privada frente ao interesse cultural público, ampliando a interferência do Estado na preservação cultural. (FALCÃO, 1984, p.28)

O projeto de Mário de Andrade contemplava a proteção de todas as formas de manifestações artísticas, tanto a erudita, quanto a popular e a dos povos indígenas, todas fartamente descritas como exemplos de uma "cultura aberta" desses tipos com inúmeros exemplos, como obras premiadas ligadas às Belas Artes, os instrumentos indígenas de caça e pesca e até vilas de quilombos do Recife. Ao contrário, o decreto chegava a este nível de detalhe do projeto, mas indicava categorias artísticas que deveriam ser protegidas e que somente seriam especificadas em uma posterior regulamentação.

Mário de Andrade propôs preservar os bens móveis e imóveis, e mais os usos, hábitos, fazeres, lendas, folclore, música e até as supertições populares. O Decreto-lei restringiu-se às coisas, isto é, bens móveis e imóveis. (FALCÃO, 1984, p.28)

Como se pode depreender, esses limites colocados na origem atingem a abrangência da atividade do IPHAN, reduzindo a política federal de preservação do patrimônio artístico histórico a uma política de preservação arquitetônica de monumentos de tijolos e cimento.

Havia uma razão para focar os trabalhos de preservação apenas nos monumentos construídos. Era uma opção pela ação educativa que os intelectuais ligados ao IPHAN nos seus primeiros anos entendiam ser o melhor caminho para dar os 
primeiros passos no campo da preservação, em um país sem tradição nesse assunto. O que definiu e regulamentou a esfera de atuação do IPHAN implicou em "uma opção pelo patrimônio que tem como origem os feitos da elite econômica e política do país (palácios, fortes, sedes de grandes fazendas, sobrados urbanos, etc.)". (SILVA, 2001, p.25)

O fato de o IPHAN voltar seus trabalhos para patrimônios culturais concretos daria mais visibilidade ao trabalho do Instituto e à presença da história na vida cotidiana das pessoas e, portanto, mais legitimidade ao trabalho de preservação. Segundo Falcão (1984, p.29), a política seguida não era uma intenção deliberada, por parte do Estado e da elite brasileira, de mistificação cultural. Segundo o autor não havia um movimento de oposição ou de proposição de uma política de preservação alternativa à política em curso. Mesmo a proposta de Mário de Andrade, se colocada em prática, não teria obtido apoio político, portanto, não conseguiria se sustentar.

A cultura brasileira era um instrumento importante para o governo Vargas promover atividades que exaltassem o que de mais característico tinha o povo e para que também o Estado, através dela, pudesse controlar a construção de uma imagem ideal do país, a construção de uma identidade nacional. (SILVA, 2001, p.26)

A interferência do Estado Novo na área cultural também podia ser vista na propaganda e na imprensa, consideradas áreas estratégicas para a divulgação do regime e para fomentar a mobilização popular, tendo em vista que até 1943 o Regime se utilizou de técnicas de desmobilização social e de contenção, física ou simbólica, através da censura e da repressão. Assim, ancorado em políticas sociais e de propaganda oficial, parte para uma fase de mobilização popular, com controle social, ou seja, um acordo entre o Estado e a sociedade, personificado na pessoa de Vargas.

Ao enviar uma equipe à Alemanha para conhecer o funcionamento do Ministério de Imprensa e Propaganda de Hitler, dirigido por Joseph Goebels ${ }^{6}$, Vargas já pensava as bases do seu Regime, no que diz respeito à instrumentalização da propaganda. Portanto, essa viagem fornecerá as bases para a constituição do Departamento de Imprensa e Propaganda (DIP).

O DIP aparece nove anos depois do golpe, em dezembro de 1939, originário do Departamento Oficial de Propaganda (DOP) instituído em 1931 pelo Governo Provisório, que passa a se chamar, em 1934, Departamento de Propaganda e

\footnotetext{
6 Paul Joseph Goebbels participou como ministro do Ministério Nacional para Esclarecimento Público e Propaganda do governo nazista, que controlava a imprensa, o rádio, o teatro, os filmes, a literatura, a música e as artes plásticas.
} 
Difusão Cultural (DPDC) ${ }^{7}$. Ficava vinculado diretamente ao presidente da República e tinha como atribuições coordenar e implementar a propaganda governamental a nível nacional, inclusive orientando instituições públicas e privadas no que era relacionado à propaganda oficial. Era composto pelas Divisões de Divulgação, de Radiodifusão, de Cinema e Teatro, Turismo e Imprensa, esta última muito atuante no trabalho de censura e propaganda em jornais.

Vinculado diretamente ao presidente, tinha como objetivos ${ }^{8}$ : centralizar, coordenar, orientar e supervisionar a propaganda nacional, interna e externa, ser agente complementar à informação dos ministérios e entidades públicas e privadas; censurar o teatro, o cinema, a radiodifusão, a literatura social e política e a imprensa; incentivar a produção de filmes nacionais; organizar e dirigir o programa de radiodifusão do Governo, entre outros.

O seu diretor, Lourival Fontes, se torna a figura mais importante do Estado Novo, pois a propaganda governamental era fundamental para formar uma opinião pública favorável ao regime. A comunicação era considerada o instrumento para que o governo conhecesse, conquistasse e ocupasse o país.

Era clara a admiração de Lourival Fontes aos regimes totalitários, nazista e fascista. As técnicas de manipulação voltadas a provocar as mudanças de sensibilidade e a organização da estrutura responsável pela propaganda política demonstram essa identificação.

A propaganda, portanto, ganha a dimensão de um discurso político capaz de extravasar os restritos cálculos de elite e atingir um público mais amplo, para o que era essencial o recurso a uma linguagem centrada em imagens, símbolos e mitos. (GOMES, 2003, p.114)

O DIP passa a gerir toda a campanha institucional do governo e a promover ações de fortalecimento do regime, fazendo uso maciço da imagem de Getúlio Vargas como "pai da pátria", ou seja, "...um esforço de colocar os meios de comunicação de massas a serviço direto do Poder Executivo" (SCHWARTZMAN et al, 2000, p.105).

$O$ governo Vargas também foi eficiente no que diz respeito a se comunicar com o povo, graças ao trabalho do DIP, que consegue ampliar a audiência no rádio, dando voz ao povo brasileiro. A propaganda e a censura ajudam a manter em destaque o político populista.

7 O DPDC é resultado da reformulação do antigo Departamento Oficial de Propaganda, criado em 1931, responsável pela propaganda estatal do governo de Vargas.

8 Disponível em <http://www2.camara.leg.br/legin/fed/declei/1930-1939/decreto-lei-1915-27-dezembro-1939411881-publicacaooriginal-1-pe.html>. Acesso em 20/out/2012. 
A eficiência do DIP é, em parte, resultado de seu poder e da direção impressa pelo seu diretor, Lourival Fontes. Poder de ação e direção, por sua vez, somam-se a todo um contexto próprio dos regimes de direita, dos regimes totalitários e absolutos. O poder de falar sozinho, de ser o único porta-voz livre, dá inteira liberdade de ação ao governo, o que o torna praticamente único a se expressar publicamente durante o Estado Novo. (CARONE, 1977, p.169)

Em linhas gerais, o DIP era o responsável pela prática da censura e, por contraditório que possa parecer, por promover a produção nacional cinematográfica, ampliar o relacionamento da imprensa com os Poderes Públicos, ordenar a programação de radiodifusão e controlar a entrada de publicações estrangeiras.

Enfim, para evitar toda derrapagem, a improvisação, momento de libertação, é proibida. Essas medidas "externas" são substituídas pela autocensura, muito praticada, e pela troca comum e funcional da docilidade por diversos favores prestados. Soma-se a isso a obrigatoriedade do registro das publicações, a censura da imprensa escrita (a imprensa é controlada pelas cotas de importação do papel e dos textos) e radiofônica (as estações de rádio estão em plena expansão, 63 em 1937, 11 em 1945), o financiamento direto de muitos jornalistas pelo Departamento de Imprensa e Propaganda e 0 abastecimento de quase dois terços das matérias publicadas nos jornais. (ROLLAND, 2003, p.95)

Nesse período havia um controle do que se publicava ou noticiava a respeito do regime. Quase não se liam nos jornais notícias claras ou subentendidas que falassem mal do governo. O rádio foi um veículo de comunicação muito utilizado pelo DIP, inclusive por meio de um programa recém-criado, a "Hora do Brasil", que levava informações oficiais à população. O cinema também é obrigado a exibir os oficiais Jornais Nacionais.

A popularidade de Vargas aumenta, assim como o culto a sua personalidade. Era intenção se mitificar o Estado, a nação e a pessoa do chefe de Estado, que passaria a representar o destino do país e os desejos de toda sociedade.

A construção do mito de Vargas tem um resultado mais efetivo depois de 1940, quando se passa a festejar seu aniversário de forma pública, com repercussão em todas as primeiras páginas dos jornais. O DIP promove o festejo da data, repetido pelos órgãos oficiais, em todos os Estados, e se encarrega de publicar e distribuir livros, folhetos que divulgavam os feitos do presidente.

Os laços entre o povo e o chefe de Estado estabelecem-se pela relação mítica, criando assim uma identidade absoluta entre o representante e os representados. (CARONE, 1977, pp.166-169) 
Segundo Edgar Carone (1977, p.166), o fenômeno mítico em torno de Vargas tem uma grande complexidade e se relaciona pela primeira vez a um político, numa conjugação de três fatores que possibilitaram a criação do mito em torno do seu governo: "A movimentação de massa popular, a confusão de valores das classes dirigentes e a ação do Estado como forma de propaganda e repressão." Havia um padrão de repetição das qualidades do presidente que podiam ser observadas em pessoas menos importantes, isso para demonstrar que todos os líderes partidários do Estado Novo eram portadores de características e personalidades diferenciadas, próxima a Vargas, mas nunca iguais a ele.

Denis Rolland (2003, p.89) considera que no Estado Novo aconteceu uma iniciativa inédita de mitificar o Estado, na qual o destino nacional e as aspirações da sociedade se concretizavam nas figuras da nação e do chefe do Estado, uma relação mítica que criava "...uma identidade absoluta entre o representante e os representados".

O poder do DIP permanece enquanto o regime ditatorial do Estado Novo se mantém, mas não resiste à abertura democrática de 1945, que trouxe muitas críticas à sua atuação e que conseguiram por um fim ao seu controle e censura. Neste momento o DIP é transformado em Departamento Nacional de Informações (DNI).

\subsubsection{O cinema no Estado Novo}

A questão cultural e educacional será alvo dos governos de Vargas, inclusive no Estado Novo, quando o seu Ministro da Educação e Saúde, Gustavo Capanema, desenvolve uma ampla reforma nessas áreas. O cinema é visto, então, como uma das formas de educar as massas, dentro do projeto pessoal e político de Getúlio Vargas voltado à construção de um novo país, como podemos observar no trecho do seu discurso de $1934^{\circ}$, feito aos cinematografistas:

Sanear a terra, polir a inteligência e temperar o caráter do cidadão, adaptando-o às necessidades do seu habitat, é o primeiro dever do Estado. Ora, entre os mais úteis fatores de instrução, de que dispõe o Estado moderno, inscreve-se o cinema. Elemento de cultura, influindo diretamente sobre o raciocínio e a imaginação, ele apura as qualidades de observação, aumenta os cabedais científicos e divulga o

\footnotetext{
${ }^{9}$ Disponível em <http://www.biblioteca.presidencia.gov.br/ex-presidentes/getulio-vargas/discursos1/1934/04.pdf/download>. Acesso em 31/out/2012
} 
conhecimento das coisas, sem exigir o esforço e as reservas de erudição que o livro requer e os mestres, nas suas aulas, reclamam.

Sobre o apoio ao setor:

Amparando a indústria cinematográfica nacional, o Governo Provisório cumpriu ditame imperioso e irrecusável.

Sobre a capacidade de penetração:

O cinema será, assim, o livro de imagens luminosas, no qual as nossas populações praieiras e rurais aprenderão a amar o Brasil, acrescendo a confiança nos destinos da Pátria. Para a massa de analfabetos, será essa a disciplina pedagógica mais perfeita, mais fácil e impressiva. Para os letrados, para os responsáveis pelo êxito da nossa administração, será uma admirável escola.

E Vargas finaliza o discurso, indicando os principais instrumentos de promoção do Regime:

\begin{abstract}
Associando ao cinema, o rádio e o culto racional dos desportos, completará o Governo um sistema articulado de educação mental, moral e higiênica, dotando o Brasil dos instrumentos imprescindíveis à preparação de uma raça empreendedora, resistente e varonil. E a raça que assim se formar será digna do patrimônio invejável que recebeu.
\end{abstract}

Anita Simis (1996, p.44) destaca a opinião de Jean-Claude Bernardet e Maria Rita Galvão de que o cinema uniria o disperso e seria a comunicação entre as diferentes partes do território brasileiro e, no governo pós-revolucionário de 1930, serviria a um projeto onde se gestava a construção de um Estado moderno, consolidado pela identidade nacional e dentro da perspectiva política de Vargas, um elemento de integração de todos os setores da sociedade brasileira.

Como já dissemos, a década de 1930 foi um período conturbado da história do nosso país. Em menos de dez anos o Brasil assistiu a deposição da República Velha, a revolta de São Paulo contra Getúlio Vargas, a Revolução Constitucionalista de 1932, a Intentona Comunista de 1935 e a Integralista em 1937.

É importante destacar que a Constituição de 1934 definia o encaminhamento do país rumo à normalidade democrática, com a consolidação das intuições políticas. Mas em meio a tantas incertezas e radicalismos dos diferentes grupos sociais, Getúlio age de maneira ambígua e, com apoio dos militares, dá um golpe de Estado, suspendendo a Constituição, as garantias individuais e fechando o Congresso Nacional. Estava consolidada assim uma ditadura, deixando Vargas com plenos poderes, por meio dos quais ele imprime um amplo projeto político e econômico, 
mas, sobretudo, educacional e cultural.

Já nos idos de 1930 havia uma pressão, junto ao governo de Getúlio Vargas, por parte de cineastas e produtores, representados pela Associação Cinematográfica de Produtores Brasileiros (ACPB), para que fosse tomada alguma medida de estímulo e proteção ao cinema brasileiro.

O Presidente então cria uma comissão encarregada de elaborar um estudo da situação do cinema brasileiro, presidida por Francisco Campos, então Ministro da Educação e Saúde, com a participação de Mario Augusto Teixeira Freitas, Lourenço Filho, Mário Behring, Ademar Gonzaga, Ademar Leite Ribeiro, entre outros, que ao final formulou um anteprojeto que veio a se tornar o Decreto-lei n. 21.240, de 1932, que nacionaliza o serviço de censura dos filmes cinematográficos, cria a Taxa Cinematográfica para a educação popular, entre outras decisões. (SIMIS, 1996, p.94)

Estrategicamente, Vargas colocava, de maneira crescente, foco na questão cultural como forma de promover a identidade nacional. Cria o Serviço de Censura (antigamente subordinado ao Ministério de Educação e Saúde), com maior nível de autonomia e atribuições, agilizando processos, mas estabelecendo novos controles. Esse "novo" olhar do Estado para o cinema teve como um dos primeiros resultados a decisão do prefeito do Distrito Federal, a cidade do Rio de Janeiro à época, Pedro Ernesto, em destinar verbas para a viabilização do cinema educativo nas escolas e instituir uma comissão para acompanhar a implementação da lei.

O uso do cinema na educação já era cogitado na Europa desde 1910. Na América, desde as primeiras experiências com o cinematógrafo também já se vislumbrava o seu uso para fins educacionais. Thomas Edison, avaliando que o ensino de muitas disciplinas era enfadonho na forma oral e expositiva, decide fazer filmes sobre física, química e história natural para colaborar na educação dos seus netos, iniciativa que vai ser aprovada pelos pedagogos e implantada nas escolas norte-americanas.

Em 1927, o governo italiano, a partir do sucesso do uso do cinema para fins educacionais, apresenta à Sociedade das Nações $^{10}$ a proposta da criação de um Instituto Internacional de Cinematografia, sendo aprovada e ficando a direção sob a responsabilidade da entidade.

O Instituto, que teve grande aceitação, deveria favorecer a produção de filmes educativos, divulgá-los internacionalmente, por meio de permuta, e promover o aperfeiçoamento dessa técnica cinematográfica. Mussolini, em seu discurso de

\footnotetext{
${ }^{10}$ Ver informações na nota de rodapé, página 14.
} 
inauguração, ressaltou "a grande vantagem do cinematógrafo em relação ao livro e ao jornal: falar uma língua compreensível a todos os povos da terra". (SERRANO; VENANCIO, 1930, p.31)

No Brasil, a educação estava na pauta das discussões, inclusive sendo considerada como fundamental para se obter transformações no país. A reforma do ensino de Fernando de Azevedo vai incluir o cinema educativo em seu programa, criando a Comissão de Cinema Educativo, que se encarrega de organizar e promover uma grande exposição, a Exposição de Cinematografia Educativa, de aparelhos de projeção, destinada a demonstrar aos professores as vantagens do uso desses equipamentos em sala de aula. A exposição foi considerada um marco na introdução do cinema no meio pedagógico brasileiro.

Mesmo antes de 1928 já haviam propostas para utilizar o cinema como auxiliar do ensino. Serrano e Venâncio, que também entendiam a importância do cinema na educação, indicavam que não havia no Brasil, naquele momento, um plano ou uma ação organizada, nem mesmo recursos, para garantir uma produção regular do cinema educativo. Ao contrário, eram vistas apenas produções esparsas, experimentais, que não conseguiam concorrer com a produção americana. Os autores salientavam que sem estrutura técnica e sem capacitação humana não seria possível levar adiante a proposta de incluir o cinema no ensino brasileiro.

Não basta reconhecer e proclamar o valor educativo do cinema, nem tampouco inserir em leis e regulamentos disposições referentes ao assunto. Para aplicar de fato o cinema à educação nacional (propositadamente dizemos educação e não instrução), cumpre resolver toda uma série de problemas preliminares. (SERRANO; VENANCIO, 1930, p.33)

A orientação era de que o cinema deveria ser condicionado às regras da pedagogia, e não o contrário, e também que não deveria ser o único meio de aprendizagem. Havia limites para sua utilização: a adaptação do filme ao ensino era obrigatória, o mesmo não poderia substituir uma aula e seria feito em conjunto com o educador $\mathrm{e}$ o cineasta e, por fim, recomendado para os temas que o movimento fosse um fator essencial. Também se recomendava que a projeção fosse acompanhada de explicação de um professor. (SERRANO; VENANCIO, 1930, p.66-67).

O cinema substitui as descrições verbais ou escritas de quaisquer figuras concretas de coisas, fatos ou fenômenos. Embora o faça com indiscutível superioridade, porque é o melhor processo de representação de imagens, ainda não exclui a necessidade da palavra do professor... Nos casos em que o cinema pode substituir o 
quadro-negro, o mapa e as descrições verbais, é, também, indispensável o comentário do professor para ajustá-lo às peculiaridades e disposições físicas da classe. (ALMEIDA, 1931, p.190)

O assunto cinema educativo vai receber atenção dos educadores Jonathas Serrano e Francisco Venancio Filho, cujo livro por eles publicado, Cinema e Educação, é uma espécie de manual de utilização do cinema no ensino e também um registro das ações iniciais de utilização do cinema educativo no Brasil e no mundo. $\mathrm{Na}$ mesma seara estava Joaquim Canuto Mendes de Almeida, cineasta, roteirista e diretor que realizou vários filmes até que abandona o cinema para seguir sua carreira jurídica.

Mendes, por conta de sua atividade, logo compreendeu a afinidade existente entre cinema e educação, esta última vista como agente de adaptação do indivíduo à sociedade, e que o cinema, portanto, poderia interferir nessa formação, de maneira positiva, mas também negativa. Segundo ele, as características do homem seriam determinadas “... pelo clima e pelos alimentos, pelo ar e pela água”, indicando que o cineasta atribuía um peso exagerado à influência do meio sobre a formação das pessoas, menosprezando a autonomia individual. Segundo ele:

Ora, a educação visa justamente adaptar o indivíduo à sociedade. Vai, logicamente, às raízes do mal. Procura ordenar para o educando as imagens das coisas e dos fatos, consoante a experiência da humanidade ou do grupo social e não do indivíduo: de maneira que todos os homens tenham, mais ou menos, o mesmo ângulo de apreciação do mundo e, na medida da capacidade de cada um, possam das imagens das coisas e fatos, extrair ideias e originar princípios de conduta individual, favoráveis à socialização. (ALMEIDA, 1931, p.12)

Na visão de Mendes, o cinema era um forte aliado dos professores, os verdadeiros possuidores do conhecimento, e um instrumento apropriado para atingir o principal objetivo da educação, que seria o de ajustar o indivíduo à vida coletiva, ao meio social. O uso das imagens no ensino, em todos os níveis, possibilitava aos estudantes uma proximidade maior ao objeto estudado, portanto, na opinião do cineasta:

O educador sabe que deve coordenar em face do educando, não só as imagens das coisas e dos fatos reais, mas, também, quando é preciso, sugerir-lhe ordenadamente, à imaginação, imagens semelhantes das coisas e dos fatos ausentes ou passados. (ALMEIDA, 1931, p.12)

Que continuava: 
A fotografia animada sana essa falha. Retrata qualquer imagem da realidade, ainda mesmo a imitação de coisas ou fatos, atos ou fenômenos desde as mais simples às mais completas e complexas reconstituições dramáticas. É o cinema! E com que vantagens o faz! (ALMEIDA, 1931, p.187)

O autor defendia o cinema com ardor, enfatizava sua versatilidade técnica e sua aplicabilidade no ensino, tornando-o mais dinâmico, sobretudo pela sua capacidade de condensar tempo e espaço. Para ele o cinema:

Domina o tempo e o espaço, o movimento e a extensão. Sabe concentrar doze horas num só minuto com a mesma perícia com que estende um século num só dia. $\mathrm{Na}$ mesma área da tela, projeta micro-organismos e cadeias de montanhas. Acelera e aumenta o tamanho das cousas. E essas imagens mágicas, coordena-as a vontade, sem restrições de espécie alguma. Porque o cinema está sucessivamente em qualquer parte, possui o dom da ubiquidade, acha-se, ao mesmo tempo, em lugares diferentes, tudo pode gravar, ligar, separar, ajuntar, intercalar, encadear no sentido mais útil ao ensino. (ALMEIDA, 1931, p.187)

O uso do cinema na educação, pela força das imagens, que permaneciam por mais tempo na lembrança dos estudantes era considerado uma ferramenta importante par o ensino. O seu uso em diferentes disciplinas, à exceção das abstratas, especialmente no ensino do desenho e de idiomas, e um "complemento" no ensino da geografia e da história, era uma opinião compartilhada por Serrano e Venancio.

$\mathrm{Na}$ história, que estuda o passado, o cinema também cabe pouco. Caberá, sim, de agora por diante para fixar os acontecimentos contemporâneos, que já deviam ter exigido o recolhimento dos filmes que fossem documentos para a História, como já há em Haia. Os de restauração histórica, não são aconselháveis. Por maior que seja o luxo de alguns, há sempre larga porção de fantasia, em que não é possível marcar a linha divisória da realidade. É essa a opinião da maioria dos especialistas de cinema e de história. (1930, p.79)

Como se pode notar, Mendes reconhecia o poder do cinema no inconsciente das pessoas, sem deixar de considerar também a força que tinha o seu lado espetáculo e os efeitos nocivos do cinema comercial sobre a formação da personalidade, que justificaria inclusive a censura. Dizia ele:

Findo o espetáculo, o espectador adquiriu um progresso intelectual, e, dominado pela excitação de ânimo que as cenas Ihe infundiram, está pronto para seguir pela imitação, a moralidade da fita. Na primeira oportunidade em que surja à frente desse indivíduo uma situação que se assemelhe, mesmo remotamente, à da tela, há de lhe ocorrer, consciente ou inconscientemente, a respectiva solução 
cinematográfica, como uma que já viu, ao mesmo uma vez na vida, dar resultado. (ALMEIDA, 1931, p.147)

Apesar de reconhecer o cinema como um negócio, o cineasta fazia uma oposição entre o cinema educativo, o bom cinema, portador de valores morais, do patriotismo e o cinema comercial, o mau cinema, prejudicial à formação do indivíduo, uma opinião compartilhada por outros intelectuais que também pediam maior controle sobre ele por parte do Estado.

\begin{abstract}
Atribuindo, assim, também à censura o papel de incentivadora do "bom cinema", percebemos o quanto Canuto Mendes apenas fazia eco a todas aquelas reivindicações, procurando considerá-las em vista de uma futura institucionalização legal. Reivindicações que estavam presentes também nos discursos de outros educadores. (SALIBA, 2003, p.45-46)
\end{abstract}

Mendes entendia que a questão moral deveria acompanhar o cinema, tanto quanto voltado para educação, como para diversão. O Estado deveria ser o controlador do cinema comercial, da diversão, sugerindo que esse controle fosse feito por um órgão técnico, indicando que o Instituto Nacional de Cinema Educativo seria uma instância capaz de controlar e promover filmes educativos, o que veio acontecer em 1937. Como se vê o Decreto-lei n. 21.240/32 em sua essência trazia a primeira regulação para o cinema nacional e, avaliado sob uma perspectiva mais ampla, foi o primeiro momento em que o Estado passa a adotar um conjunto de medidas, certo que tímidas, mas que sinalizavam a construção dos primeiros alicerces de uma política de estímulo e fortalecimento para o setor cinematográfico.

É importante destacar a relevância do decreto no que diz respeito ao reconhecimento que ele dava, de maneira textual, ao "cinema educativo" e, também, ao estímulo à produção e à veiculação de uma programação quinzenal de “...espetáculos infantis educativos e filmes nacionais (desde que filmados no país e com motivos brasileiros)..." (CALDAS; MONTORO, 2006, p.198)

Ainda segundo os autores, o decreto estabelecia que para cada metro de filme apresentado ao serviço de censura cinematográfica, era cobrada uma taxa voltada para fim educativo e, também, concedia estímulo aos produtores e exibidores, com isenções e/ou redução de impostos e taxas, condicionados à obrigatoriedade da exibição do material educativo, seja no início ou no final do filme principal que estava sendo exibido, reduzia-se em até $15 \%$ os impostos para importação de filmes comuns, películas virgens e filmes educativos, além de prever a proporção anual de filmes nacionais, obrigatórios na programação dos cinemas brasileiros. (2006, p.197- 
Vargas empreendeu uma estratégia política ambígua, pois dialogava, no setor cinematográfico, tanto com os produtores, como com os cineastas, ao mesmo tempo em que acenava aos distribuidores e proprietários de salas de cinema com uma série de concessões buscando evitar maiores conflitos. Como os demais políticos populistas do período, Vargas fazia da ambiguidade uma arte de conciliar o inconciliável.

Assim, o presidente acena para os cineastas com certas concessões, mas deixa de atender reivindicações mais importantes pleiteadas pelos grupos reunidos em torno das revistas Cinearte e Paratodos ${ }^{11}$, dentre elas, o fortalecimento do filme de longa metragem comercial e o estímulo à formação de um modelo industrial de estúdios semelhante ao norte-americano.

Desde a década de 1920, a visão do grupo ligado a estas revistas nacionais, no que se referia às principais questões do cinema brasileiro, era calcada no modelo industrial norte-americano, uma visão focada principalmente na questão do domínio dos recursos destinados às técnicas que deveriam referendar uma produção em escala e de qualidade dentro da perspectiva de produtos massivos.

Entretanto, esta visão se mostrava equivocada diante das efetivas questões estruturais nas quais o cinema brasileiro estava inserido, como a dificuldade para obter capital para realizar filmes, mesmo que, na sua maioria, fossem baratos. Podemos destacar também a falta de adequação de foco aos reais problemas do cinema nacional e a entrada, a partir de 1915, das distribuidoras norte-americanas no Brasil (Fox, Universal e Paramount), que inundaram o mercado com seus filmes, ocupando o espaço dos filmes franceses. (GOMES, 1996)

Para produtores e diretores, o exibidor local era visto como o vilão do processo. Porém é importante observar o filme norte-americano a partir de um contexto mais amplo, qual seja, o livre acesso dos mesmos a um número cada vez mais crescente de salas de cinema, onde as majors norte-americanas eram apenas a extensão da força e da ideologia americana no plano político e sobretudo comercial.

Os ataques que partiam da revista Cinearte contra os exibidores eram uma contradição, por estes serem os seus maiores anunciantes, evidenciando também a postura ambígua dos integrantes da publicação, alguns inclusive, cineastas.

\footnotetext{
${ }^{11}$ A Cinearte era uma revista brasileira sobre cinema, fundada no Rio de Janeiro em 3 de março de 1926 por Mário Behring (1876-1933) e Adhemar Gonzaga (1901-1978), tendo encerrado sua circulação em 1942, após 561 edições. A Paratodos foi uma revista brasileira, fundada na década de 1920, de circulação semanal e conteúdo cultural e que era ligada politicamente ao Partido Comunista Brasileiro. Otávio Gabus Mendes atuou como crítico na revista em 1925, que mais tarde foi dirigida por Jorge Amado e Oscar Niemeyer.
} 
O cinema americano começa a pensar globalmente, a exemplo do que já faziam outros setores da indústria norte-americana e canadense, inclusive. Com o surgimento de um novo bloco econômico, que manteria alguns pressupostos da $\mathrm{MPPC}^{12}$, com o objetivo de controlar o mercado cinematográfico norte-americano, acrescenta-se agora, de maneira voluptuosa, o apetite por novos mercados. (GATTI, 1999a, p.39-40)

Cabe aqui destacar de que forma o exibidor nacional estava atrelado ao sistema do cinema norte-americano:

Com a finalidade de atingir objetivos de alijar a concorrência do mercado, as produtoras-distribuidoras tinham como hábito a prática do blind-booking e do block- booking ${ }^{13}$. Literalmente, reserva cega e reserva em bloco, respectivamente. A reserva cega acontecia num momento em que os produtores vendiam um filme, em produção, para o exibidor, com antecipação da bilheteria. Portanto, involuntariamente, o exibidor tornava-se um coprodutor dos filmes, no entanto, sem os direitos destes. Já a reserva em bloco é a prática mais comum e consiste em o exibidor, ao programar um determinado filme de uma distribuidora grande, é obrigado a comprar uma série de outros títulos, sem a mesma atração comercial. Através deste sistema as distribuidoras norte-americanas garantiam a exibição dos seus filmes deficitários. (GATTI, 1999a, p.36)

E quando olhamos comparativamente outros países europeus encontramos a mesma dificuldade na cinematografia europeia. Deve-se lembrar que o exibidor fazia parte de um cenário complexo, que ultrapassava os limites de Hollywood, e que vinha se formando desde a I Guerra com o enfraquecimento do cinema francês e da cinematografia europeia em geral. O cinema inglês tentava sobreviver à prática comercial do block-booking, que colocava o exibidor numa situação limite, pois para obter bons filmes ele era obrigado a alugar, na forma casada, muitas vezes filmes bastante medíocres e que ficavam vinculados à programação por um ano. (SADOUL, 1983, p.355)

Todas as discussões vivenciadas por Ademar Gonzaga em seu período de crítico de cinema trabalhando nas revistas Paratodos e Cinearte o levaram a visitar os estúdios de cinema de Hollywood, quando pode conhecer mais profundamente a estrutura técnica e de produção do cinema norte-americano. Na volta, importa diversos equipamentos e funda no Rio de Janeiro, em 1930, a Cia. Cinematográfica Cinédia,

\footnotetext{
12 MPPC: Motion Picture Patent Company, poderosa organização que dominava a indústria cinematográfica e que pretendia acabar com os produtores independentes. Disponível em <http://www.chambel.net/?p=102>. Acesso em 14/abr/2011.

13 Block-booking é uma prática comercial americana, inicialmente implantada em países como a Inglaterra, na qual os exibidores só podiam escolher os filmes de longa-metragem em lote e a renda (antes do Decreto 4064) era dividida igualmente entre todos os filmes, prejudicando os filmes nacionais, que tinham recordes de bilheteria. (SIMIS, 1996, p.127) Blind-booking seria a compra de um lote de filmes, composto de filmes conhecidos, acompanhados de outros desconhecidos.
} 
o primeiro estúdio brasileiro, com sede, estrutura e estúdios projetados visando a produção de filmes nacionais.

Agir em defesa do longa metragem nacional representaria, além da perda do mercado nacional para o filme norte-americano, também conflitos de interesses junto ao governo norte-americano, que poderiam gerar possíveis retaliações políticas e comerciais por parte daquele governo.

A avaliação sobre a questão da taxação do filme impresso e virgem era um aspecto importante e muito bem vindo aos interesses, mesmo que distintos, dos importadores, cineastas e produtores brasileiros. O barateamento do negativo e do positivo favorecia a produção e a ampla copiagem dos filmes norte-americanos destinados ao circuito lançador, mas viabilizava também a subsistência dos laboratórios e dos empregos gerados a partir desta demanda.

\subsubsection{O Cinema Educativo}

Em razão da Revolução Constitucionalista de 1932, somente em julho de 1933 é que surge Convênio Cinematográfico Educativo, uma estratégia de mediar as diversas reivindicações entre os setores conflitantes, pois determinava a imediata e obrigatória exibição de filmes nacionais e concedia a subvenção e a premiação, tanto à "comédia como ao drama", culturais, científicos ou educativos, "falados em português e produzidos no Brasil". (ALMEIDA, 1999, p.74)

$\mathrm{Na}$ verdade, o Convênio Cinematográfico Educativo contempla de alguma forma o interesse dos cineastas por apresentar alguma regulamentação, sobretudo no que diz respeito à obrigatoriedade de exibição do filme nacional nas salas de cinema, usando o subterfúgio de vincular o filme brasileiro ao filme educativo que, na prática, passa a "ocupar" o espaço do longa metragem brasileiro.

Ainda que houvesse no Artigo 13 do Decreto-lei n. 21.240/32 a determinação do Ministério da Educação e Saúde que fixava uma proporção das metragens de filmes nacionais com base na capacidade do mercado brasileiro e na qualidade dos mesmos, conforme acordado por um grupo de produtores e cineastas e o Museu Nacional, isso nunca foi seguido na prática. Outra promessa não cumprida foi a realização de um congresso que reunisse pessoas ligadas à área cinematográfica, como os da ACPB, distribuidores, importadores, professores-educadores, jornalistas 
e censores.

É importante destacar o fato de a ACPB ter encaminhado ao presidente um memorial, responsabilizando a pressão feita pelos importadores estrangeiros sobre os exibidores pela não exibição de filmes nacionais e, em consequência, pela inexistência do filme nacional. (SIMIS, 1996, p.109)

Vemos aqui a primeira articulação no plano institucional envolvendo integrantes do meio cinematográfico, concretizada na apresentação de um projeto de lei que estipulava a "...obrigatoriedade de exibição de um filme de no mínimo 250 metros lineares, isto é, $10 \%$ da metragem média de um programa cinematográfico e sua fiscalização pelas "autoridades policiais”. (SIMIS, 1996, p.110-111) Os exibidores, então, na luta pelos seus interesses e por estarem comprometidos (como ainda hoje estão) com as distribuidoras norte-americanas, articularam uma forte campanha através da imprensa contra essa obrigatoriedade.

A questão fundamental dessa reclamação dos exibidores era com referência à diminuição dos seus lucros por conta da venda casada de filmes estrangeiros com curtas metragens nacionais e da renda da bilheteria que deveria ser dividida entre ambas as partes, de forma que o curta nacional se apresentava como um custo a mais para o exibidor.

Outro fato que interessava aos dois lados era a questão cambial ligada ao filme virgem, ou seja, as facilidades para a importação desse produto e a redução dos valores por quilograma, que passou de $10 \$ 000$ réis para $1 \$ 000$ réis. Mesmo depois da depreciação da moeda em 1929, o poder de compra se manteve no mesmo patamar, o que favorecia nitidamente os interesses das distribuidoras norteamericanas aqui instaladas.

Segundo Simis (1996, p.102), a gestão da ACPB junto a Sales Filho, diretor da Imprensa Nacional, se concretiza na obtenção da redução da taxa cinematográfica para o filme educativo (taxa de censura), de $300 \$ 000$ réis por metro linear para $200 \$ 000$ réis, barateando os custos para o produtor nacional e encarecendo em $33 \%$ a comercialização dos filmes estrangeiros, diferenciando e favorecendo o filme nacional.

A introdução da obrigatoriedade da exibição e a transformação, em 1935, da

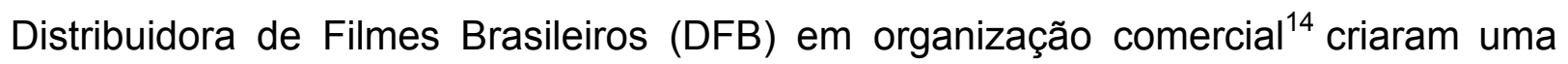

\footnotetext{
${ }^{14}$ Inicialmente um braço da ABPC tinha a incumbência de regular o mercado de filmes curtos. Em 1935 obtém personalidade jurídica e estrutura comercial, tornando-se a primeira iniciativa de distribuição coletiva no cinema brasileiro. (RAMOS; MIRANDA, 2000, p.175)
} 
expectativa positiva entre os produtores nacionais, que vislumbravam uma nova perspectiva para o cinema brasileiro.

O cumprimento dessa obrigatoriedade consistia em apresentar oito filmes por semana, com três cópias cada um, ficando a distribuição a cargo da DFB, também responsável pela fiscalização, com o objetivo de evitar que houvesse uma concorrência predatória entre as distribuidoras com rebaixamento dos preços. Convencionou-se então que deveriam ser feitos 500 filmes ao ano para suprir a obrigatoriedade. Depois de poucos meses foram lançados um pouco mais de 100 filmes produzidos por 19 empresas, no ano seguinte o número sobe para 400 filmes e 62 empresas, ou seja, uma tendência de aumento progressivo da produção cinematográfica.

O Estado continua a agir como mediador das disputas entre produtores e exibidores, até que fez um acordo, a pedido da ACPB, que estabeleceu uma divisão das salas de cinema em cinco categorias, que pagariam um valor fixo pelo número de dias de exibição de filmes de até 150 metros lineares e o compromisso dos exibidores em sempre exibir filmes da DFB.

Porém, este acordo foi, ao longo do tempo, sendo descumprido, de modo que das 1.750 salas existentes somente 471 cumpriam a obrigatoriedade da exibição, representando uma perda de renda de $75 \%$ para os produtores que, descontentes, passaram a exigir a aplicação de punições legais, obrigando o Estado a instituir novos instrumentos de controle e de punição.

\subsubsection{Plano Político Cinematográfico}

Se antes do golpe de 1937 vemos um Vargas mediando relações no plano político e cinematográfico, seja como presidente do governo provisório, seja como eleito de fato, é apenas em 1934 que o cinema nacional vai fazer parte efetivamente do seu projeto cultural, mas dentro de um contexto completamente diferente do que tinha sido discutido com os produtores e cineastas.

Em 1936 foi criada a comissão instaladora do Instituto Nacional de Cinema Educativo $(\mathrm{INCE})^{15}$, órgão subordinado ao Ministério da Educação e Saúde Pública, resultado

15 Segundo Ramos e Miranda, foi em 1937, por meio da Lei n. 378, Artigo 40, que o INCE é oficialmente instituído. (2000, p.299) 
do protagonismo da questão educacional nas grandes discussões nacionais. É nesse período que se inicia a produção, aquisição e adaptação de filmes educativos voltados à distribuição e exibição nas escolas públicas do país e é também quando o Estado define sua política para área cinematográfica com a aplicabilidade do Artigo 22 do Decreto-lei n. 21.240/32, que previa a criação de um órgão técnico dentro do ministério.

O INCE, criado e dirigido por Edgar Roquette Pinto, com a missão de promover e orientar o uso da cinematografia para fins educativos, contou com o cineasta Humberto Mauro, a convite de Roquette Pinto, à frente das produções cinematográficas do Instituto por mais de vinte anos, ininterruptamente.

Havia um claro alinhamento do INCE à ideia de Gustavo Capanema, Ministro da Educação, que almejava criar um órgão capaz de "transpor os limites apertados das instituições existentes, buscando atingir, com a sua influência cultural, a todas as camadas populares" e que entendia ser o INCE "um aparelho vivaz, de grande alcance, dotado de um forte poder de irradiação e infiltração, tendo por função o esclarecimento, o preparo, a orientação, a edificação, numa palavra, a cultura de massas". (SCHWARTZMAN et al, 2000, p.104)

Uma ampla política para produção do filme educativo e de documentários para órgãos do Governo Federal foram as principais atividades do INCE, coerentes à visão de Capanema, ou seja, de um cinema educativo e também como "aparelho para educação popular".

Por meio do INCE foi realizado, na forma de coprodução com o Instituto do Cacau da Bahia, o filme histórico O Descobrimento do Brasil (1936), lançado um pouco antes do golpe do Estado Novo e que, curiosamente, vai ilustrar uma das estratégias do Regime que estava por vir: a promoção de personagens, fatos e feitos históricos que enaltecessem e resgatassem o passado do país, buscando sempre o fortalecimento da identidade e da cultura nacional.

Uma das estratégias de Vargas, dentro do seu projeto político e cultural, foi a aproximação com a "elite pensante". Intelectuais como Rosalina Coelho Lisboa Miller, Fernando Magalhães e Roquette Pinto, entre outros, se reuniram para articular uma ampla reformulação cultural e educativa.

No ano de 1938 é criado o Departamento Nacional de Propaganda (DNP), originário do DPDC de 1934, que dava continuidade à política do governo Vargas de controle da informação transmitida pelo rádio e pela imprensa, iniciada em 1931. Vinculado ao Ministério da Justiça e Negócios Exteriores pretendia-se, através de sua atuação, 
estabelecer a integração do país e o lançamento de novas bases para a constituição da sociedade brasileira.

Gustavo Capanema, o grande artífice da reforma educacional, tinha o objetivo de reformular as grades curriculares do ensino básico e médio, peça fundamental no projeto político, ideológico e cultural fascista do Estado Novo de Getúlio Vargas. Capanema afirmava que o cinema poderia "...influir beneficamente sobre as classes populares, instruindo e orientando, instigando os belos entusiasmos e ensinando as grandes atitudes e as nobres ações." (SCHWARTZMAN et al, 2000, p.104). Neste momento o cinema já desponta como um instrumento forte de promoção da ideologia do Regime.

Ainda segundo Schwartzman, Capanema pretendia transformar o cinema de um simples meio de diversão para um "aparelho de educação", valendo-se das suas políticas de estímulo à indústria cinematográfica e também do apoio dado à censura, pois entendia que o cinema poderia, sem um direcionamento de sua produção, "...agir perniciosamente, pela linguagem inconveniente, pela informação errada, pela sugestão imoral ou impatriota, pela encenação de mau gosto", portanto, o DPDC deveria "...cuidar do cinema como aparelho de educação popular" e, com a colaboração do Departamento de Educação, "cuidar do cinema como meio de ensino". (SCHWARTZMAN et al., 2000, p.104-105)

O papel reservado ao cinema brasileiro dentro do planejamento do Estado Novo seria o de disseminar a propaganda política através dos cinejornais produzidos pelo DIP, seus documentários ou seus filmes de cunho histórico e educativo, que acabavam por ocupar o pouco espaço de trabalho que havia para as empresas produtoras, aumentando a dificuldade delas em se manter na atividade por terem que concorrer com o próprio Estado. De acordo com Maria Rita Galvão e Carlos Roberto de Souza:

\footnotetext{
O DIP começa a produzir documentários e jornais cinematográficos, e com a produção oficial institucionalizada, as produtoras independentes perdem boa parte do seu mercado. Além da concorrência desigual, têm de enfrentar censura sistemática. Alguns produtores e cinegrafistas conseguem transformar-se em funcionários públicos, filmando diretamente para o DIP, ou para suas agências estaduais, mas a maior parte é marginalizada. (GALVÃO; SOUZA, 1984, p.472473)
}

Havia um forte viés de propaganda nos cinejornais do DIP, que visavam o controle social e a convergência entre as diferentes opiniões e a dar destaque a manifestações de apoio ao regime. 
Muitos desses filmes realçaram as manifestações de apoio ao governo, projetando imagens de massas ao som de palmas durante discursos nas inaugurações e festejos, disseminando o sentimento de unanimidade, de cooperação, de aceitação das diretrizes impostas. Foi valendo-se da montagem de imagens autênticas que tais filmes garantiram a credibilidade nas mensagens governamentais, pois sem elas a propaganda não atingiria seus objetivos. (SIMIS, 1996, p.54-55)

O poder e a abrangência de atuação do DIP indicavam o grau de intervenção do Estado nas atividades voltadas à disseminação cultural e de ideias, em especial no cinema. Mesmo antes da existência do DIP, Lourival Fontes já tinha a intenção de produzir filmes, o que só não aconteceu por conta do corte de verbas feito pelo Congresso. Havia no DIP uma Divisão de Cinema e Teatro, que cuidava da censura prévia dos filmes e da produção do Cine Jornal Brasileiro (CJB), lançado em 1938, depois do fechamento do Congresso.

Um ano depois, o Decreto-lei 1949 institucionalizava a medida: "o DIP, promoverá a edição de filmes, contendo aspectos naturais e de atualidades, serviços públicos, iniciativas governamentais, recomposições históricas nacionais, etc." (SIMIS, 1996, p.64)

\subsubsection{O Cinema como Indústria}

Estimulada pela iniciativa de Ademar Gonzaga com sua Cinédia, a atriz Carmen Santos funda em 1933, com capital do seu marido Antônio Seabra, industrial do setor têxtil, a Brasil Vox Film, que em 1935 passa a se chamar Brasil Vita Filme, uma das poucas referências da tentativa de industrialização do cinema nacional. A Brasil Vita Filme realizou alguns longas, como o Onde a Terra Acaba (1934), Favela dos Meus Amores (1935), Cidade-Mulher (1936), Argila (1940), o complexo Inconfidência Mineira (1936-48), Rua sem Sol (1954) e o Rico ri à toa (1957). (SIMIS, 1996, p.121) No mesmo período surge a empresa Waldow Filme, do americano Wallace Downey, responsável por realizar uma série de filmes musicais como o Alô, Alô Carnaval (1931), dirigido por Adhemar Gonzaga, Alô, Alô, Brasil (1935), que colaboraram com a expansão da produção dos musicais, um gênero de filme que passará a ser muito importante na história do cinema brasileiro. Downey se associa à Sonofilmes, do industrial Alberto Byington Jr., com quem realiza os longas metragens João Ninguém (1936), Banana da Terra (1939), Laranja da China (1940) e centenas de cinejornais, mesmo enfrentando dificuldades para a produção, ou seja, a falta de capital que 
financiasse os filmes de longa metragem. Assim, o que lhes restava como alternativa para continuarem atuando no ramo cinematográfico eram os filmes feitos sob encomenda, como os documentários e os cinejornais.

Ao final da década de 1930 as empresas produtoras, de modo geral, dependiam dessas encomendas e tanto a Cinédia, como a Brasil Vita Film, realizavam apenas cinejornais, apesar do aumento da produção de filmes nacionais nesse período. É nesse contexto que o Estado acena com a obrigatoriedade da exibição para o filme de longa metragem, através do Decreto-lei n. 1949, de 30 de setembro de 1939, que passa a fixar a proporcionalidade do filme nacional de um filme/ano para cada sala de cinema.

Mesmo antes da assinatura deste decreto, as empresas nacionais Sonofilmes, Cinédia e Brasil Vita Filmes, para se manterem ativas, já vinham realizando filmes de longa metragem e investindo na complexa superprodução do filme Inconfidência Mineira (1948). Podemos destacar aqui alguns desses longas: Favela dos Meus Amores (1935), Cidade-Mulher (1936) e Argila (1940), de Humberto Mauro para a Brasil Vita Filme; Bonequinha de Seda (1936), de Oduvaldo Vianna e O Ébrio (1946), de Adhemar Gonzaga, dirigido por Gilda de Abreu, Grito da Mocidade (1937) e Aves sem Ninho (1939), dirigidos por Raul Roulien, para a Cinédia.

Segundo Anita Simis, em seu artigo A contribuição da cota de tela no cinema brasileiro, de $2009^{16}$ :

Pelos dados numéricos obtidos em fontes oficiais, no período compreendido entre 1935 e 1939 houve um crescimento ascendente da produção de filmes nacionais (de 486 para 789), enquanto que seu principal concorrente, o filme americano, perdeu posições, chegando em 1939 a indicar uma cifra menor que a de 1937 (de 1.349 passou para 1.496). Ora, tendo em vista que até 1939 não havia nenhuma outra medida legislativa de incentivo à produção cinematográfica, a não ser a diferença de um para dez na taxação alfandegária imposta aos filmes virgens em relação aos filmes impressos, a obrigatoriedade de exibição para os filmes foi em grande medida responsável pela salvação da produção cinematográfica nacional. (2009, p.139)

Ainda segundo a autora:

Mais que uma conquista, tal medida (Decreto-lei 1949/39) foi instituída quando os curtas independentes ganharam um novo competidor no espaço destinado à exibição compulsória: os filmes oficiais, cuja exibição passou a ser exigida pelo DIP, e por isso mesmo rigorosamente cumprida, ao menos nas grandes cidades como

16 Revista O público e o privado, n. 14. Editora da Universidade Estadual do Ceará. Disponível em <http://www.politicasuece.com/v6/admin/publicacao/A_contribuicao_da_cota.pdf>. Acesso em 19/abr/2011. 
São Paulo e Rio de Janeiro. Ao mesmo tempo instituíram-se ainda os percentuais de locação e distribuição dos filmes de curta e longa metragem (nem sempre cumpridos) e igualou-se o prazo de permanência da exibição dos filmes nacionais e estrangeiros. De acordo com os dados, a obrigatoriedade de exibição do longametragem pode ter influído no salto ocorrido em 1940, de sete para 13 filmes, mas em seguida, há uma perda considerável. Por outro lado, considerando-se o volume total da produção (filmes de curta, média e longa metragem de ficção ou não ficção) podemos notar que ela se manteve no mesmo ritmo dos anos anteriores. Certamente esta produção se refere mais aos filmes de curta-metragem levando em conta que algumas empresas privadas trabalharam inclusive para atender às encomendas oficiais, chegando até a diminuir a produção de longas metragens. (2009, p.140)

Para surpresa de todos, em meio à II Guerra Mundial, é fundada no Rio de Janeiro, pelos irmãos José Carlos Burle e Paulo Burle e Moacyr Fenelon, a Atlântida Cinematográfica, uma empresa com uma estrutura limitada, que será responsável, mais adiante, por disseminar um novo gênero cinematográfico, as chanchadas ${ }^{17}$. Neste período a produção cinematográfica do país estava concentrada nas encomendas dos cinejornais feitas pelo DIP e a Cinédia havia produzido apenas o filme de longa metragem de Raul Roulien, o Grito da Mocidade (1937). Esses anos também são marcados pela escassez de negativo.

Com a chanchada, a Atlântida vai se consolidar como uma das grandes produtoras brasileiras realizando, ainda no período do Estado Novo, filmes como Moleque Tião (1943), seguido de Gente Honesta (1944), Tristezas Não Pagam Dívidas (1944) e Não Adianta Chorar (1945). Em 1946, outro filme de destaque foi o Gol da Vitória, de José Carlos Burle, com Grande Otelo no papel do craque Laurindo, produção bastante popular sobre o mundo do futebol, que remetia, em muitas cenas, ao célebre Leônidas da Silva (o "Diamante Negro"), o melhor jogador de futebol da época.

É também de 1946 a comédia musical Segura essa Mulher de Watson Macedo, com Grande Otelo e Mesquitinha. O filme foi um grande sucesso, inclusive na Argentina. Em 1947 foi a vez de Este Mundo é um Pandeiro, um filme fundamental para se entender a produção da Atlântida. Neste filme, Watson Macedo delineava, com grande precisão, algumas características que estariam presentes nas chanchadas: a paródia à cultura estrangeira, em especial ao cinema feito em Hollywood, e certa preocupação em expor as mazelas da vida pública e social do país.

\footnotetext{
17 Gênero de grande importância no cinema nacional, o filme musical com enredo, ao qual o grande público brasileiro teve enorme identificação nos anos 1940, 1950 e 1960, por estes trazerem atores e cantores para protagonizar histórias que traduziam nas telas a realidade brasileira.
} 
Importante destacar a entrada estratégica de Severiano Ribeiro como sócio majoritário da Atlântida, configurando um momento único no cinema brasileiro, pois agora, além de exibidor, com um grande conjunto de salas e distribuidor, conseguiria o máximo de lucro, por ter o controle da cadeia produtiva do cinema.

\subsubsection{Fim do Estado Novo: uma nova fase para o Cinema Nacional}

A tentativa de Vargas de se manter no poder através de manobrar a opinião pública e os seu fieis seguidores, o que ficou conhecido como "Queremismo", foi abortada pelo ultimato dos militares, destituindo-o do poder. Chegava ao fim o Estado Novo, assumindo o poder, por convocação dos militares, o presidente do Superior Tribunal Federal, José Linhares, que convocou eleições gerais para o ano de 1946.

Com a mudança no comando do governo, foram extintas diversas estruturas autoritárias do Estado Novo, entre elas o DIP, substituído pelo DNI, ao mesmo tempo em que novas instituições eram criadas, como o Serviço de Censura e Diversões Públicas (SCDP) tendo uma divisão só para as atividades voltadas à censura de diversões públicas e manifestações artísticas, como peças teatrais, filmes, músicas e programas do rádio, separando então a censura de diversão pública da censura de imprensa.

Em 1946, o Decreto-lei n. 20.493 aprova o regulamento do SCDP e com sua chegada, deixava de ser produzido o Cinejornal e também de ser concedido apoio e incentivo às empresas cinematográficas nacionais. Por outro lado, o mesmo decreto condicionava a exibição de filmes superiores a 1.000 metros com a exibição de filmes nacionais, confeccionados em laboratório nacional com o mínimo de 180 metros e obrigava os cinemas a exibir anualmente no mínimo três filmes nacionais, de entrecho e de longa metragem e instituía a "taxa cinematográfica para educação popular", que não seria cobrada das cópias de filmes estrangeiros que fossem reveladas no Brasil. (SIMIS, 1996, p.137)

Logo depois do encerramento dos trabalhos da Assembleia Nacional Constituinte, o então deputado federal da bancada paulista do PCB, Jorge Amado, encaminhou para a Câmara Federal o projeto de Lei n. 879, que propunha a criação do Conselho Nacional de Cinema (CNC) e que ordenava normas de produção, regulação, distribuição e importação de filmes. $O$ projeto também previa a concessão de 
subvenções financeiras, de bolsas de estudos e de financiamento, sendo a Carteira de Crédito Agrícola e Industrial do Banco do Brasil uma das opções de se obter os empréstimos.

O CNC, amparado pelo Decreto-lei n. 6016/43, seria então um serviço público estatal, descentralizado e com personalidade jurídica de direito público, ou seja, "...um órgão abrigado nas estruturas do Estado sob o controle do setor produtor". (SIMIS, 1996, p.140)

O projeto de Jorge Amado também retomou a questão das atividades de propaganda e imprensa, que no passado eram fiscalizadas pelo DIP, novamente obrigando importadores de cinejornais a também adquirir películas para cinema produzidas no Brasil.

É importante entender, como bem observou Anita Simis, que muitos dos acordos comerciais brasileiros eram feitos como permuta de matérias-primas, como, por exemplo, o carvão inglês em troca do nosso couro. O jornalista e censor do DPDC, Raimundo Magalhães, era a favor do intercâmbio baseado no sistema de permutas comerciais, como vemos: "Por que não faremos também uma troca de celulóide, exigindo que as companhias estrangeiras importem um mínimo determinado de películas brasileiras sobre a metragem total dos filmes que dão entrada no nosso país?" (1996, p.143)

É perceptível como a questão do cinema suscitava muita polêmica e um permanente conflito de interesses entre produtores nacionais e distribuidores estrangeiros. A instituição da Lei n. 1949/39 que obrigava importadores de cinejornais a adquirir o correspondente do mesmo de produtores nacionais, gerou um ponto de tensão entre as embaixadas do Brasil e dos Estados Unidos. Apesar da pressão dos importadores contra o intercâmbio de cinejornal entre os dois países, esse embate foi resolvido de maneira diplomática, na forma de "uma troca de compensações", devido à importância que o mercado brasileiro representava em termos de lucro para os grandes distribuidores de filmes americanos.

\subsection{OS ANOS JK}




\subsubsection{O Projeto Desenvolvimentista}

Do ponto de vista social, o Brasil havia mudado desde a década de 1940, deixando de ser exclusivamente agrário e estava vivendo um processo de transformação econômica, que ocasionava a movimentação das pessoas que saíam do campo para irem para as cidades, em busca de melhores condições de vida.

O suicídio de Vargas deixou um vácuo político, preenchido com a posse em 1954 de Café Filho, como substituto legal da presidência. O Brasil vivia um período de grande instabilidade institucional, com problemas que se aprofundavam, e Café Filho não contava com respaldo político para fazer mudanças profundas no plano econômico como Vargas possuía. Medidas como limitação do crédito, a redução das despesas públicas, a retenção automática do imposto de renda sobre os salários, deveriam ser imediatamente adotadas diante do quadro de agravamento da inflação e do aumento do déficit da balança comercial.

Nesse momento os partidos começam a se articular, buscando formar chapas eleitorais para eleição. Os candidatos indicados foram Juscelino Kubitscheck (JK), pelo PSD e João Goulart, pelo PTB. Segundo a legislação eleitoral vigente, permitiase votar em separado para presidente e vice-presidente, assim o medo de que houvesse a retomada da política varguista contribui para que saiam vencedores Juscelino, como presidente e Goulart, como seu vice.

Entretanto, nos bastidores, era tramado um golpe, com o apoio da UDN, para que Café Filho impedisse a posse dos novos eleitos, mas que teve de ser adiado devido à doença do presidente que culminou com seu afastamento do poder. De acordo coma Constituição, o substituto legal foi o então presidente da Câmara dos Deputados, Carlos Luz, que fica como presidente interino, e que também vai tentar, com o apoio das Forças Armadas lideradas pelo general Álvaro Fiúza de Castro, impedir a posse dos eleitos. Carlos Luz sofre um contragolpe, armado pelo general Henrique Lott, acabando assim afastado do poder e o Congresso aprova a cassação do mandato de Café Filho. Assume o vice-presidente do Senado, o senador Nereu Ramos, que em 31 de Janeiro de 1956 dá posse a Juscelino Kubitschek e João Goulart.

O presidente eleito Juscelino Kubitschek era um político carismático, nacionalista, como Vargas tinha um estilo político próprio de governar. No Congresso, Juscelino 
conseguiu ter maioria parlamentar e base de sustentação política por conta da aliança PSD-PTB, que Ihe garantia estabilidade nas votações. O bloco de oposição liderado pela UDN era minoria, mas tinha uma forte atuação política. Juscelino desenvolveu uma postura não dogmática e ideológica, cercada de astúcia, habilidade e ambiguidade. Sinalizava ser um homem do diálogo, o que the protegia das manipulações, evitava o confronto e não abria espaço para especulações que pudessem causar desestabilização de seu governo, visto pelos opositores como uma continuidade das políticas de Vargas.

O governo de JK vai se destacar com o lançamento de duas propostas: projetar e traçar uma estratégia de melhoria da ocupação da parte oeste do território nacional a partir da construção da futura capital do Brasil, Brasília, e traçar o plano de modernização do país, o Plano Nacional para o Desenvolvimento, também conhecido como Plano de Metas.

O Plano de Metas, que tinha o objetivo de acelerar o processo de acumulação e o aumento da produtividade, concentrava-se em 30 metas estratégicas, agrupadas em cinco grandes setores: energia, transportes, alimentação, indústrias de base, educação. Buscava-se construir um modelo de desenvolvimento econômico, com base em um pesado investimento público e, sobretudo, com a participação intensiva de capital privado internacional, buscando criar um parque industrial nacional. $\mathrm{O}$ Plano conhecido como "50 anos em 5", indicava a intenção do governo JK de transformar cinco anos de realizações e respeito à democracia em 50 anos de progresso. (SKIDMORE, 2000, p.205-206)

Para o desenvolvimento do Plano de Metas, JK se articulou em duas frentes. Uma delas foi atrair investidores estrangeiros por meio da concessão de incentivos especiais para a instalação de uma planta industrial, desde que estes se associassem a uma empresa brasileira. Outra foi atrair a confiança do empresariado nacional, visto que o país reunia condições para que a demanda interna de consumo fosse mantida, ou até elevada, a partir da instituição de uma política de créditos, pavimentando o caminho para a substituição das importações e para a criação de indústrias nacionais de bens de capital.

Os últimos anos de Dutra viram uma nova fase de processo de industrialização "espontânea". Durante o truncado período de Vargas surge uma política de desenvolvimento projetada para dirigir e guiar a industrialização suplementar, tornada possível pela política cambial e pela oportunidade favorável em relações de troca, após 1949. Durante os anos de Kubitschek a substituição das importações entraria já em outra fase, com maior ênfase na criação de indústrias de bens 
de capital. (SKIDMORE, 2000, p.205)

Uma das estratégias concebidas pelos técnicos do governo foi o desenvolvimento de um planejamento a ser articulado pelos Grupos Executivos ${ }^{18}$. É importante destacar que os investimentos públicos foram feitos de maneira escalonada, com o intuito de poder superar entraves em determinados setores que se encontravam estrangulados e que apresentavam sua capacidade estrutural bastante limitada, como as áreas de energia e transporte. O BNDE teve um papel importante no governo de JK, pois além de conduzir todo o processo de industrialização do país, também atuou na captação de fundos para os grandes projetos de infraestrutura, permitindo que fossem reunidas condições favoráveis para a instalação de uma indústria automobilística nacional. (SKIDMORE, 2000, p.207)

Durante todo o mandato de JK a questão mais estratégica era a de manter a estabilidade política (lembrando que o fiador de sua posse foi o general Teixeira Lott), enfrentando e superando as diversas crises que se instalavam na área civil e militar. Para isso JK foi um pragmático. Nas crises militares o presidente interferia para acalmar os ânimos fazendo algumas concessões, como a compra de equipamentos militares, se a crise atingia os aliados, JK oferecia cargos, eliminando assim as insatisfações e se a crise era com os seus opositores, ele evitava o conflito direto, passando ao largo das críticas. No jogo político a direita o acusava de tentar adular o trabalhismo militante, dando como prova o aumento em 1958 do salário mínimo e JK procurava construir o apoio fazendo concessões aos mais diversos grupos em toda extensão do espectro político.

O método de Juscelino de consolidar apoio era fazer concessões importantes a ambos os polos do espectro político. Um exemplo de seus esforços para aplacar a esquerda foi sua reação à pressão de políticos nordestinos, que reclamavam que a região sul ganhava excessivamente com a industrialização, deixando o populoso nordeste com sua baixa renda ainda mais para trás. Para acalmar essa queixa Juscelino aceitou uma proposta para uma nova autoridade federal, a Superintendência para o Desenvolvimento do Nordeste (Sudene), para promover o desenvolvimento econômico da região baseada num documento (Operação Nordeste) de Celso Furtado. A ideia era estimular investimento e especialmente industrialização em áreas nordestinas selecionadas. (SKIDMORE, 2003, p.202-203)

\footnotetext{
18 Para operacionalizar seu Plano de Metas, JK cria um órgão subordinado diretamente à presidência da República, o Conselho do Desenvolvimento, que tinha a função de coordenar o detalhamento e a execução do plano. Este Conselho contava com a colaboração de especialistas ligados aos setores contemplados no Plano de Metas e de especialistas do próprio governo e atuava por meio de Grupos Executivos, que tinham a tarefa de liberar incentivos para o setor privado, de modo que as metas fossem atingidas.
} 
JK procurava também construir uma imagem que transmitisse e pudesse espelhar nos brasileiros um senso de confiança, que era parte da sua própria personalidade, realçando sua crença no processo democrático e no futuro do país, trazendo para si o papel de uma liderança moderna, um presidente que criou as condições que permitiram ao Brasil dar um grande salto para o futuro através da industrialização.

\begin{abstract}
Do lado positivo, o Brasil obteve tecnologia inestimável, embora geralmente apenas por meio de investimentos de multinacionais estrangeiras. O país também viu o crescimento de um mercado nacional, concentrado basicamente no centro-sul. A perspectiva de ganhar espaço neste mercado atraiu firmas estrangeiras, mesmo que apenas pelos investimentos modestos. Finalmente, industriais e empresários brasileiros começaram a acreditar que poderiam ter um desempenho em padrões mundiais. (SKIDMORE, 2003, p.207)
\end{abstract}

Ainda que JK fosse cercado de muitas críticas pela maneira como conduziu processo de industrialização do Brasil, o fato foi que ele conseguiu criar condições efetivas para o crescimento da economia, por meio do aumento da estrutura de geração de eletricidade e da criação de uma malha viária extensa.

A construção de uma nova capital para o Brasil, Brasília, um projeto futurista do urbanista e arquiteto Lúcio Costa e do arquiteto Oscar Niemeyer que pensaram um modelo de cidade planejada, servia não apenas para ampliar a inserção do país no mundo, como também para mostrar a capacidade do Brasil para empreender uma obra moderna e grandiosa, libertando-o dos estereótipos a que sempre esteve sujeito. Contudo, a obra de Brasília, apesar da beleza de seu projeto arquitetônico, foi cercada de muita polêmica, principalmente pelo seu custo. Segundo Skidmore:

Mas havia também um lado negativo da estratégia de crescimento de Juscelino que derivava da maneira como ela era financiada. A poupança interna permanecia cronicamente baixa, mantendo assim também o investimento baixo. E o influxo esperado de capital estrangeiro para complementar o investimento nacional não era suficiente para erguer o investimento brasileiro ao nível necessário para o alto crescimento sustentado a longo prazo. (2003, p.205)

O governo de JK vai apresentar então um quadro de maior complexidade econômica. Se por um lado a construção de Brasília abria novas perspectivas de trabalho e a ocupação das terras a oeste do Brasil, por outro, aumentava o financiamento do déficit do setor público. Outras questões nacionais de certa gravidade, como a reforma agrária e educação, e que não tinham recebido atenção governamental, exigiam do governo medidas urgentes. O investimento maciço de recursos públicos em grandes obras e na construção de Brasília gerou uma inflação crescente e um 
acúmulo de déficit na balança de pagamentos.

Muitos economistas criticavam o Brasil pelo que chamavam de
"inflação do financiamento" - o financiamento dos déficits do setor
público pela simples impressão de dinheiro - porque ela
inevitavelmente redistribuía renda e riqueza para os setores de alto
crescimento (incluindo alta especulação). Esse deslocamento não
podia continuar por tempo indefinido, por causa dos limites naturais a
tais transferências e porque, finalmente, os perdedores no processo
se exasperariam o bastante para interrompê-lo. (SKIDMORE, 2003,
p.206)

Esse cenário preocupava muito o FMI. A saída para o Brasil foi a de assinar um acordo de estabilização com o FMI para conseguir cobrir a conta do déficit de pagamentos e assim retomar o fôlego para continuar crescendo. Este acordo que implicava em cortes no orçamento, restrições salariais e de crédito provocou uma reação negativa em todo país.

A esquerda tomou a proposta do FMI como uma afronta, entendendo como a perda da soberania do governo em conduzir o país a partir das suas próprias diretrizes.

Foram pesadas as críticas dirigidas a Juscelino, que se viu acusado de se submeter aos interesses estrangeiros. JK estava então frente a um dilema. Se aceitasse a estabilização proposta pelo FMI, seria acusado de entreguista pela esquerda, a economia desaceleraria, o Plano de Metas não seria implementado e o crescimento ficaria pelo caminho, interrompendo o sonho da modernidade. Juscelino, para manter o processo de crescimento econômico, assume o risco político e rompe com o FMI, uma atitude que o fez ser visto como um grande nacionalista, que deixou a esquerda desconcertada e a direita hesitante, diante do forte apoio popular que ele recebeu.

JK também recebeu a colaboração de pensadores para levar à frente seu projeto desenvolvimentista, em especial aqueles ligados ao Instituto Superior de Estudos Brasileiros (ISEB), uma autarquia vinculada ao antigo Ministério da Educação e Cultura. O ISEB foi um importante centro de pesquisa que reuniu um grande número de intelectuais de pensamento liberal que formularam, pensaram e desenvolveram a ideologia nacional-desenvolvimentista, base de sustentação das políticas governamentais de $\mathrm{JK}$, buscando o diagnóstico e soluções para os problemas brasileiros nos campos político, econômico e social, assunto que será abordado em item específico deste trabalho.

Juscelino adaptou seu discurso nacionalista-desenvolvimentista ao plano social de maneira habilidosa, obtendo a simpatia de todas as classes sociais. Para isso, JK 
atuava oferecendo concessões diferenciadas: à burguesia oferecia benefícios e créditos para a ampliação da produção de produtos nacionais, de modo a reduzir a importação de produtos, aos proprietários de terra, a política de apoio financeiro aos cafeicultores, sobretudo nas ocasiões em que havia oscilações negativas no preço do produto no mercado.

A classe média que era inicialmente muito refratária a $\mathrm{JK}$, pois entendia que 0 desenvolvimentismo estava diretamente vinculado ainda à imagem de Vargas e aos casos de corrupção e de favoritismo político daquele governo, aos poucos vai sendo seduzida pelo progresso econômico. A classe que mais recebeu a atenção de JK foi a dos trabalhadores, que recebeu bons aumentos salariais como compensação ao controle governamental sobre a estrutura sindical.

O mais importante era que o rótulo de nacionalismo de Kubitschek se baseava na elite administrativa e empresarial brasileira e não em qualquer movimento de massas. Kubitschek não fez qualquer tentativa no sentido de misturar populismo esquerdista com nacionalismo desenvolvimentista, ato que se esperava uniria a classe média aos militares de oposição. (SKIDMORE, 2000, p.210-211)

O país parecia estar bem encaminhado até que algumas distorções começaram a aparecer em decorrência de certas opções políticas e econômicas de JK. Ainda segundo Skidmore:

Mas os críticos salientaram o que consideravam importantes custos em termos de efeitos sobre o bem-estar social. Estes incluiam crescente desigualdade de renda, na medida em que os trabalhadores industriais ganhavam mais do que os dos setores agrícolas ou de serviços. É claro que mesmo os ganhos dos trabalhadores industriais eclipsam-se em comparação aos $2 \%$ ou $3 \%$ do topo composto de grandes proprietários de terras, comerciantes, banqueiros, corretores, industriais e magnatas imobiliários. Além disso, a inevitável concentração da indústria no centro-sul exacerbou as desigualdades de renda entre esta região e o resto do Brasil, especialmente o nordeste. (SKIDMORE, 2003, p.109)

JK, assim como Vargas, sempre soube transitar nas estruturas paralelas do poder, e conseguia colocar suas manobras em prática em função da fragilidade institucional dos partidos, que eram em sua maioria oligarquias estaduais que agiam na lógica da barganha, procurando atender seus interesses políticos imediatos, relegando ao segundo plano as questões políticas mais importantes do país.

Ao final dos anos 1950 e início dos anos 1960 já começava a aparecer na sociedade brasileira setores mais conscientes, ligados a camadas mais populares, e que 
passaram a reivindicar mais espaço no cenário político, pois não se sentiam representados socialmente. JK percebe que os tempos são outros e que aquele equilíbrio da balança política, mantido por ele no passado, já começa a apresentar sinais de fratura e se mostrava inviável, principalmente pelo avanço do político populista de esquerda, eleito governador do Rio Grande do Sul, Leonel Brizola.

Ainda que se reconheça o perfil conciliador e habilidoso de JK, não havia no horizonte da próxima eleição de 1960 um candidato com as mesmas características dele, capaz de transitar entre um sistema partidário de forma pragmática e improvisada em certos momentos.

Leonel Brizola tinha um discurso calcado na estratégia de mudança procurando catalisar a insatisfação dos segmentos populares e propondo uma maior participação da população na prosperidade econômica, com a melhora do padrão de vida e dos salários. Além disso, o discurso radicalizava dentro da perspectiva populista e nacionalista propondo outras medidas que levavam preocupação aos representantes do capital estrangeiro, como uma mais eficaz regulamentação do investimento estrangeiro e também uma atitude governamental mais firme e agressiva no que se refere à interferência dos credores financeiros sobre as nossas dívidas.

Os discursos políticos passam a abordar mais veementemente a questão das demandas sociais das classes proletária e rural, começando a incomodar o poder político. A falta de uma reforma agrária só acentuava as demandas dos grupos sociais sem terra, marginalizados, mas apoiados por líderes locais, que reivindicavam maiores salários, melhores condições de trabalho, quebrando a calmaria política que existia neste setor desde Vargas. Essas reivindicações contrariavam os interesses dos proprietários rurais, que achavam que essas ideias da esquerda eram muito radicalizadas. Exigir terras e direitos era diretamente associado ao comunismo e à perda de suas propriedades.

O Brasil de então vai presenciar uma agudização do antagonismo social, que se dava entre os setores conservadores, que temiam perder o seu poder político e econômico; a classe media urbana que se sentia ameaçada pelo risco de perder seu status econômico e social; e a classe militar, mas todas com algo em comum entre elas: eram avessas ao populismo, pois acreditavam que ele conduziria o país para o perigo real do comunismo, pondo fim às liberdades políticas, religiosas e sociais.

A próxima eleição presidencial de 1960 somente iria acentuar essa situação, pois as oligarquias agrárias que dominavam os estados de predominância rural estavam 
muito bem representadas no Congresso Nacional, mas poderiam perder sua força, pois numa eleição presidencial o que contava era o voto nacional.

O Brasil chega aos anos 1960 com uma estrutura de poder que refletia um sistema político ultrapassado e cheio de tensões, pactuado ainda no pós-1930 pelas elites que tinham ascendido ao poder, remontando a práticas políticas defasadas, clientelistas, dentro de um sistema constitucional que já não conseguia responder às demandas da sociedade, até que vê acontecer o golpe de 1964, conduzido pelo empresariado nacional e pelos militares, uma ditadura que terminaria apenas 21 anos depois de instituída.

\subsubsection{O ISEB: Um Novo Olhar para o Brasil}

Estamos nos anos 1950, período de grandes mudanças no Brasil. Getúlio Vargas retorna ao poder, com a certeza de que deveria dar continuidade ao seu projeto de desenvolvimento nacional, iniciado ainda nos anos 1940, com a instalação de indústrias de base, como a CSN, responsável pela produção de aço em escala industrial.

Vargas anteviu de maneira estratégica que um o país não teria futuro e nem soberania se não tivesse, ao menos, domínio sobre a exploração de seus recursos naturais, o que o levou à criação de empresas estatais, como a Petrobras (petróleo), em 1953, mesmo enfrentando uma forte pressão da oposição no Congresso Nacional, principalmente em relação à Petrobras.

Esta oposição refletia uma antiga polarização na discussão e na opinião pública: de um lado estavam os nacionalistas que defendiam o monopólio da exploração do petróleo e do outro lado, os denominados "entreguistas" que, vinculados aos interesses estrangeiros, defendiam que o país não tinha todos os recursos financeiros e tecnológicos necessários para levar adiante um projeto de tal envergadura. Havia na época uma percepção sobre a importância de se ampliar os debates sobre as questões estruturais do Brasil, tendo em vista o processo de transformações que estava em curso na sociedade brasileira. Mas um acontecimento trágico, o suicídio de Getúlio Vargas, vai dar início a um período de instabilidade política e social, que perdura de agosto de 1954 até janeiro de 1956, período esse marcado por duas 
interinidades na Presidência da República: na primeira, o vice-presidente João Café Filho assume, mas depois é afastado por problemas de saúde e na segunda, quem assume é o presidente do Senado, Paschoal Ranieri Mazzilli.

A UDN, partido de grande expressão política, era um opositor ferrenho do governo Vargas, personificado em uma das suas mais destacadas lideranças, Carlos Lacerda, responsável por criar uma forte tensão política em 1956, ao tentar impugnar a eleição daquele ano, alegando que o vencedor, JK, não havia obtido na votação uma vitória por maioria absoluta. Diante da iminência de um golpe de estado tramado pelo presidente em exercício Carlos Luz, que impediria a posse, o então Ministro da Guerra, general Henrique Teixeira Lott, dá um contragolpe, mobilizando tropas militares e dando garantias constitucionais para a posse de Jk. Juscelino assume e inicia um amplo projeto de modernização do país, o seu programa de governo "50 anos em 5", com o planejamento sustentado em dois pilares: associação de investimento público com incentivo financeiro para atrair capital estrangeiro, visando criar melhores condições para instalação no Brasil das indústrias de base.

Devemos lembrar que ainda pairava sobre muitos segmentos da atividade econômica a visão do liberalismo clássico. Parte dos industriais, comerciantes e economistas ortodoxos pensavam que o melhor caminho, estruturalmente falando, seria manter o país apenas como exportador de matéria-prima e importador de bens industriais, o que beneficiava os interesses daqueles segmentos.

Contudo, como em outras épocas, esse modelo se mostrou frágil, já que a economia do país se sustentava apenas em um produto, o café (principal produto de exportação a época), portanto dependia da boa cotação, ficando à mercê da oscilação do mercado. O período de queda dos preços comprometia o saldo comercial da balança de pagamentos, acarretando graves problemas econômicos para o país.

Frente a isso, o governo JK passou a implementar através do seu Plano de Metas, uma série de transformações no plano econômico que tiveram reflexos no plano social, abrindo caminho para que parte da intelectualidade voltasse a contribuir na construção de um pensamento visando dar novos rumos ao Brasil, com o Instituto Superior de Estudos Brasileiros (ISEB) ${ }^{19}$, uma iniciativa que só havia acontecido anteriormente no período de Vargas, no Estado Novo (1937-1945), quando diversos desses intelectuais colaboraram com o governo, participando dos seus quadros,

\footnotetext{
19 Criado em 1955, pelo Decreto-lei n 57.608 assinado pelo presidente interino João Café Filho que assumira a presidência por força do suicídio da Getúlio Vargas, o ISEB só vai ganhar força no governo JK. Em 1964 é extinto, pelo Decreto-lei 53.884, assinado por Paschoal Ranieri Mazzili que respondia pela presidência provisoriamente após a deposição de João Goulart. (TOLEDO, 1997, p.203)
} 
principalmente na área cultural.

É um momento em que as decisões da presidência passam a representar os novos grupos que passam a ser hegemônicos e a reivindicar maior participação no plano econômico e político, demandando uma nova forma de atuação administrativa por parte do Estado, que propiciasse um novo ciclo de desenvolvimento, mais articulado e com uma melhor implementação e racionalização dos recursos do país. (TOLEDO, 1997, p.40)

A questão da formulação de um pensamento que possa articular uma ideologia do desenvolvimento nacional e levar o país ao crescimento econômico sustentável, já estava presente na sociedade desde meados dos anos 50 , no último ano do governo Vargas, que resulta na criação do Instituto Brasileiro de Economia e Sociologia e Política (IBESP), coordenado pelo sociólogo Helio Jaguaribe, contando com a participação de outros intelectuais de prestígio, como Candido Mendes, Álvaro Vieira Pinto, Roland Corbisier, Nelson Werneck Sodré e Alberto Guerreiro Ramos, que estarão presentes no futuro ISEB. (TOLEDO, 1997, p.203-204)

O IBESP foi um instituto de breve duração, pois apresentava algumas fragilidades, como uma imprecisão estatutária, que o impediu de obter um alcance político e intelectual necessários para o tipo de trabalho que seria desenvolvido pela instituição. De toda forma, o insucesso do IBESP gerou, em 1955, uma mobilização dos grupos que atuavam na vida nacional, que reivindicava uma ação mais efetiva por parte do Estado, voltada para o incentivo e a promoção do desenvolvimento nacional, levando o então presidente João Café Filho decretar a criação do ISEB, que permanecerá ativo durante os quatro anos de vigência do governo de JK, momento de maior atuação e relevância dos estudos e trabalhos apresentados que, segundo Toledo, sinalizava uma postura governamental com a temática da teorização do desenvolvimento. (1997, p.41)

Portanto o ISEB transita em diversos níveis, econômico, social, cultural e político, buscando uma análise ampla do país e da sua complexa realidade, com ativa participação de intelectuais que contribuíram para o debate, formulação e reflexão de uma ideologia do desenvolvimento nacional, de forma a congregar mobilizar e articular a sociedade brasileira, com um projeto e um crescimento em bases sustentáveis.

Toledo se vale das palavras de H. Jaguaribe que sintetizam a relevância do Instituto, que configurou um sistema de ideias singular no quadro da inteligência brasileira e, do ponto de visita teórico, fez críticas às limitações históricas e sociológicas do 
positivismo e do marxismo, procurando focar no "atendimento sócio cultural de nosso tempo". (1997, p.10)

A solenidade de diplomação dos primeiros estagiários, em 1956, contou com a presença de JK que destacou o trabalho do instituto, afirmando que, embora vinculado ao antigo Ministério da Educação e Cultura, o ISEB tinha autonomia administrativa e liberdade de pesquisa, para assim "formar uma nova mentalidade, um espírito, uma atmosfera de inteligência para o desenvolvimento", discurso reforçado pela fala do Ministro da Educação e Cultura, Clóvis Salgado, que expressava o desejo do governo de dar condições para que o Instituto exercesse um papel relevante de assessoria para a sustentação das ações e políticas contidas no Plano de Metas de JK.

Muitas das demandas que eram prementes para o Estado estavam há muito tempo para serem resolvidas e vinham sendo reclamadas constantemente por meio de intensa luta dos grupos sociais menos favorecidos (operários e camponeses). Neste contexto, o papel do ISEB era estratégico, pois estava sendo chamado pelo governo para dar a sua relevante contribuição para atender as principais demandas públicas, a partir de análises dos principais problemas políticos, econômicos e, sobretudo, sociais do Brasil, em um momento em que o país necessitava de profundas transformações estruturais visando promover o crescimento econômico sustentável e, por consequência, levando à população a elevação do seu padrão de vida, ou seja, diminuindo a miséria que perdurava há muito tempo.

Como se pode notar, o papel do ISEB estava a princípio bem definido pelo governo, que via o Instituto como um formulador de um pensamento autêntico nacional e um incentivo para a promoção do "desenvolvimento nacional", responsável também pelo suporte a uma boa parte das ações do governo, propondo soluções e projetos para diminuir o atraso estrutural do país. Contudo, encontraremos algumas ambiguidades na relação do Estado com o ISEB.

Uma delas é que nos quadros do Instituto participavam intelectuais e colaboradores de reconhecida militância no espectro ideológico mais à esquerda, o que naturalmente poderia acarretar, em algum momento, pontos de tensão com certos grupos sociais, especialmente os formados pelo empresariado, pelos profissionais liberais e, também com a classe média, representada no plano político pela UDN, que irá fazer, ao longo do governo JK, uma ostensiva e ferrenha oposição.

Esse cenário faz com que o governo de JK tenha que enfrentar uma delicada questão, que é a da governabilidade, praticamente obrigando-o a construir um leque 
de alianças político-partidárias, visando dar a necessária sustentação para o seu governo, sempre sob ameaça de uma instabilidade política.

Em diferentes momentos de nossa história podemos ver que a tomada de posição dos governos foi marcada, muitas vezes, por ambiguidades e contradições (ações de repressão policial, restrição das liberdades públicas), principalmente quando o Estado era obrigado a agir como mediador em conflitos sociais envolvendo classes menos favorecidas ou era pressionado pelo interesse de grandes grupos econômicos e hegemônicos locais ou nacionais, que sempre reagem quando sentem que os seus interesses estão sendo prejudicados.

A ambiguidade do governo para com o ISEB será uma constante que vai perdurar durante todo o governo $\mathrm{JK}$, visto que muitas das formulações e pesquisas realizadas pelo Instituto iam no sentido de apontar diretamente as mazelas sociais, os problemas no campo econômico, como a concentração de certos setores da atividade econômica brasileira, sempre apresentando soluções que deveriam ser implementadas, que geravam problemas no campo político, já que certos grupos nacionais hegemônicos eram representados no Congresso Nacional.

Importante lembrar que estamos em meados dos anos 1950, quando todas as questões que envolviam discussões e demandas políticas, econômicas e sociais eram sempre marcadas ou mesmo pautadas pelo debate ideológico esquerda versus direita, comunismo versus capitalismo.

Talvez seja esse o motivo que não se encontre o vocábulo "ideologia" em toda a pesquisa teórica e produção científica do ISEB, e mesmo nas formulações oficiais do Instituto, já que "ideologia" sempre vem carregada de diversos sentidos. A opção pela não utilização do termo tinha como objetivo claro evitar que no próprio interior do Estado fossem dadas possíveis conotações e significados entendidos como "inadequados", criando polêmicas que iam contra o papel que historicamente sempre se esperou que o Estado representasse: o de mediador de conflitos.

Não se poderia admitir que o Estado - "representante da nação", "conciliador das disputas e das tensões sociais", "mantenedor da ordem e da harmonia social", "promotor do bem-estar coletivo" promova ideologias. Para o pensamento oficial, as ideologias, quaisquer que sejam seus matizes, carregam consigo estigmas e marcas detestáveis - parcialidade, desarmonia, luta social. (TOLEDO, 1997, p.43)

Essa decisão era uma hábil estratégia do governo, que assume uma postura ambígua diante de possíveis atitudes e abordagens do ISEB que pudessem lhe 
causar conflitos. Assim, o Estado adota o discurso de que não se comprometia com determinadas posições, já que elas refletiam apenas a posição do autor do trabalho acadêmico. Paralelamente, cria-se um espaço para manobra política, pois as entrelinhas da posição adotada pelo governo permitem aos intelectuais continuarem a desenvolver as suas pesquisas, com ampla liberdade para a sua produção acadêmica e, o mais importante, continuando a fornecer diretrizes e orientações para o planejamento governamental.

\begin{abstract}
Contudo, a razão mais fundamental que explicaria a "permissividade ideológica" por parte do aparelho estatal prender-se-ia ao fato de que a ideologia patrocinada pelo ISEB representava os "interesses gerais" da nação. Superados, pois, estariam todos aqueles estigmas que tradicionalmente vêm colados às ideologias. Para o pensamento oficial, com a ideologia do desenvolvimento nacional, teríamos constituído um caso modelar: a ideologia não-ideológica ou, em outra versão, a ideologia "acima de qualquer suspeita". (TOLEDO, 1997, p.43)
\end{abstract}

Foi muito presente nos debates e nas discussões sobre o trabalho realizado pelo ISEB a tese do fim ou do declínio das ideologias, refutada por boa parte dos pensadores. Para eles, as ideologias nem sequer haviam sido superadas e muito menos estavam caminhando para o declínio e caberia, isto sim, forjar novas ideologias que dessem um novo suporte aos países subdesenvolvidos de modo a constituir, de maneira estruturada, uma melhor forma de desenvolvimento.

$\mathrm{Na}$ visão do grupo principal, os isebianos denominados históricos, como Vieira Pinto, G. Ramos, C. Mendes, Corbisier, H. Jaguaribe e à exceção de Werneck Sodré, frente ao momento histórico das nações subdesenvolvidas, haveria uma condição efetiva para se iniciar um processo de transformação nestas sociedades, de forma que para eles, seria o momento de se formular uma ideologia do desenvolvimento que fosse colocada em prática imediatamente.

G. Ramos negava o fim das ideologias, pois entendia que em qualquer época e sociedade a ideologia é fruto do pensamento do homem e caminha sempre no sentido de superar suas limitações históricas e sociais. Corbisier frisava que aquele momento de ingresso no processo de desenvolvimento significava uma profunda mudança em termos políticos e ideológicos. Vieira Pinto, por sua vez, entendia que as análises feitas pelos cientistas políticos enveredavam pelas categorias e formas de pensamento metropolitanas, incapazes de captar a realidade das nações subdesenvolvidas, na medida em que as elites intelectuais dos países dominantes formulavam suas ideologias, muitas vezes ingênuas e não profundamente 
comprometidas com processos de transformação.

Vê-se que havia no grupo dos isebianos muitos pontos de convergência, mas também muitas divergências, pelo fato do próprio trabalho desenvolvido e pela profundidade das discussões de ideias e projetos que aconteciam, permitia a presença de pontos de vista sempre bem distintos a respeito das mesmas questões, como a questão da "ideologia".

Para os pensadores do ISEB, quando começam a serem criadas estruturas para a instalação de condições efetivas capazes de gerar transformações nas estruturas básicas necessárias dos países subdesenvolvidos, decorre uma mudança relevante - a ruptura da consciência ingênua que começa a refletir e tomar consciência da sua realidade.

Esta questão da consciência também tem enfoques diferentes dentro do ISEB. Toledo (1997, p.45) reproduz as ideias principais de alguns isebianos publicadas à época: Vieira Pinto entendia haver alterações da estrutura material, mesmo em países atrasados, e que a implementação de meios de dominação externa que serviriam para aprofundar a exploração dessas nações, poderia suscitar em alguns indivíduos uma mudança na consciência que levaria a uma visão crítica sobre a realidade". G. Ramos entendia que o processo de construção de uma consciência crítica estava relacionado diretamente com um processo de mudanças na estrutura material, como na industrialização que, por sua vez, se reflete na urbanização, e ao final permite mudanças na forma de consumo e, por fim, Corbisier, que via na somatória de fatores presentes na sociedade humana a responsabilidade pela emergência da consciência crítica, tais como: guerra, perturbações internas que resultem em crises, desagregação das instituições locais e o desenvolvimento de novas relações no plano econômico e cultural.

A dificuldade de se alcançar a consciência crítica estaria condicionada pela ação de inércia e passividade, promovida pelas próprias práticas sociais dentro de um cenário de subdesenvolvimento, resultado de um longo processo de dominação. De acordo com Toledo (1997, p.46), as "ideologias imobilistas, presentes na estrutura colonial ou na situação de subdesenvolvimento em estagnação, reproduzem ao nível do pensamento e da ação as condições que determinam as estruturas coloniais ou subdesenvolvidas." Seria o reflexo de um simples processo de controle e manutenção da condição de dependência eterna, uma relação de submissão da colônia para com a metrópole, o que acentua o subdesenvolvimento.

Ainda numa estrutura estabelecida, como a semicolonial, e apesar dos controles 
desenvolvidos pela metrópole buscando extrair maior eficiência dos países periféricos e manter a relação de dominação, aparecem novas relações econômicas que se sucedem e que podem produzir transformações sem que seja criada uma prévia ideologia.

\begin{abstract}
As transformações ocorridas no interior da estrutura semicolonial (ou subdesenvolvida) - e que permitem a emergência da consciência crítica - não a conduzirão necessariamente ao estágio superior do desenvolvimento. Só a ideologia do desenvolvimento permitirá que aquelas mudanças assumam a feição de processo (onde haja clareza e precisão das metas e fins visados), conduzindo, promovendo e incentivando um desenvolvimento nacional integrado, harmonioso e sem grandes disparidades internas. (TOLEDO, 1997, p.47)
\end{abstract}

Para os isebianos as mudanças efetivas decorrentes da alteração da realidade material permitem o surgimento de uma consciência crítica e com ela a necessidade da tomada de atitude pelo processo de desenvolvimento.

Aos críticos, respondiam afirmando que suas colocações não eram, de maneira nenhuma, calcadas em um viés puramente idealista e nem arbitrário, pois elas indicavam que as condições presentes $e$ as demandas reais da nação subdesenvolvida convergiam para a configuração e a elaboração de uma ideologia que delineasse a questão estratégica para estes países, ou seja, a ideologia do desenvolvimento nacional identificada com a noção de autenticidade seria um dos seus pressupostos fundamentais.

Os isebianos apresentam então um postulado, no qual afirmam que a ideologia do desenvolvimento nacional deveria ter certas características, pois no cerne desta ideologia a noção de autenticidade assume um papel extremamente relevante e com distinções.

H. Jaguaribe, Corbisier, C. Mendes e G. Ramos entendiam que a questão central na abordagem da ideologia autêntica e na noção de fase ou de estrutura faseológica, se constrói no propósito do confronto das fases não como um fim, mas para se constituir num procedimento de investigação, um método das linhas diretrizes. Por sua vez, G. Ramos aborda a questão faseológica, sob o prisma do processo histórico pela observação empírica dos fatos, porque estes têm a tendência de estabelecer relações de sistemas ou de coerência entre si.

Segundo Toledo, H. Jaguaribe foi um dos que melhor desenvolveu uma formulação sobre a ideologia autêntica, importante nas discussões sobre desenvolvimento nacional. Ele afirmava que uma ideologia é representativa quando ela caminha no sentido da lógica dos discursos que representa a classe que a sustenta, mesmo que 
sempre haja interesses distintos sempre entre as classes sociais. As classes definem seus interesses em função dos contextos específicos a que estão inseridas, $\mathrm{H}$. Jaguaribe, porém, frisa que nem sempre as reivindicações almejadas por uma determinada classe social se traduzem nos interesses objetivos e efetivos nos quais devem focar e lutar. (1997, p.49)

Toledo (1997) ainda destaca que $H$. Jaguaribe entendia que por mais que uma determinada classe social almejasse estar inserida e representada socialmente, não era garantia de consumar um espaço reconhecido e validado pelos outros grupos sociais.

As aspirações de uma classe social também podem se mostrar equivocadas em razão da dominação de uma ideologia sobre a outra no interior da formação social, de forma que elas passam a se tornar vítimas da própria ideologia, perdendo, desta forma, a oportunidade de organizar a sociedade a que pertencem.

Entende-se a partir das ideias do autor que a fase se constitui em uma etapa no processo histórico de uma comunidade, determinada por uma correlação que se estabelece dentro da sociedade, a partir das relações econômicas, sociais, políticas e culturais, enquanto uma época vem a ser um processo mais amplo, uma etapa do processo histórico-social de uma cultura ou civilização.

Ainda com base nas propostas de $\mathrm{H}$. Jaguaribe, o processo de desenvolvimento que se inicia na sociedade brasileira a partir de 1930 provoca transformações, sem que houvesse confrontos, pois naquele momento os setores dominantes (exceção aos setores arcaicos ligados às estruturas semicoloniais) tinham os mesmos interesses que coincidiam com os interesses nacionais. A necessidade do desenvolvimento parecia ser de interesse comum, de forma que os interesses situacionais coincidem com as demandas também do país, como a expansão das suas forças materiais de produção.

Toledo destaca que para Jaguaribe quando não há conflitos entre as classes sociais, surge uma unidade ideológica, um processo faseológico da sociedade brasileira, no qual a ideologia do desenvolvimento pode cumprir o papel de ser uma representação autêntica dos interesses situacionais das mais diversas classes sociais que compõem a nossa sociedade e o seu conteúdo. Para o ISEB, essa unidade ideológica seria o nacionalismo.

É preciso destacar que no próprio ISEB existiam perspectivas distintas acerca do conceito e do reconhecimento da ideologia autêntica do desenvolvimento. C. Mendes, Corbisier e G. Ramos não se utilizam das distinções, feitas por H. Jaguaribe, 
de representatividade e de autenticidade para a ideologia, mas as têm como pressupostos básicos em suas respectivas elaborações.

Vieira Pinto pensa a ideologia a partir da noção da autenticidade como reflexo da consciência das massas, decorrente também da ação e da constituição de uma ideologia do desenvolvimento que seria legítima (autêntica) e a expressão de suas aspirações. Para Vieira Pinto somente a consciência das massas permitiria direcionar os caminhos para a ideologia do desenvolvimento, direções objetivas desse mesmo processo.

No trabalhador se realiza, antes do que em ninguém, a transmutação da consciência (de ingênua em crítica) como consequência do movimento de transformação da realidade material operada por sua atividade propulsora do processo do desenvolvimento. Na medida em que evolui este processo - como efeito do aprimoramento das técnicas de produção -, mais esclarecidas se tornam as suas representações da realidade. (TOLEDO, 1997, p.51-52)

Toledo continua

Assim, na medida em que a ideologia do desenvolvimento nada mais é
do que a organização, a ordenação, a sistematização das
representações vividas pela consciência das massas trabalhadoras
no ato da produção material, estas não farão outra coisa senão
reconhecer, nas elaborações dos ideólogos do desenvolvimento, os
seus próprios pensamentos, formulações a formas de sentir. (1997,
p.53)

Assim, na visão de Vieira Pinto, a ideologia do desenvolvimento reflete o pensamento natural das camadas populares, enquanto que para $\mathrm{H}$. Jaguaribe, estas deveriam ser articuladas pela burguesia, pela educação e organização ideológica, como forma de compartilhar a identificação com o desenvolvimento.

H. Jaguaribe, C. Mendes, G. Ramos e Corbisier entendem que o papel primordial da burguesia industrial era o de propagar a ideologia do desenvolvimento para as grandes massas, fazendo com que estas percebessem a elevação do seu padrão de qualidade de vida a partir deste processo.

Toledo explica que, conforme $\mathrm{H}$. Jaguaribe, o Estado é reorganizado para executar as tarefas do desenvolvimento e que as massas, na verdade são comandadas, ou seja, "não detêm o conhecimento de seus próprios interesses, devem, isto sim, ser 'conscientizadas' através 'da política ideológica' conduzida por outros grupos 'mais esclarecidos"”. (1997, p.54)

Há uma convergência das ideias de Vieira Pinto e $H$. Jaguaribe no sentido de que ambos perseguem um objetivo comum, que é o de pensar o desenvolvimento 
nacional como consolidador do capitalismo nacional, conferindo ao nacionalismo o papel de ideologia hegemônica no interior da formação social brasileira.

Importante lembrar que o período de maior relevância do ISEB, a segunda metade dos anos 1950, também foi um momento de grandes transformações mundiais e também do início do processo de desenvolvimento econômico que trazia importantes mudanças para a sociedade brasileira. Foram anos da polarização da Guerra Fria, situação que se reflete no país tanto no plano político, como também no econômico, cultural e social, gerando intensos debates e discussões que exteriorizavam visões de mundo distintas, românticas e até mesmo radicais no espectro ideológico, seja por parte da direita, como da esquerda, mas sempre marcadas pela questão da formulação ideológica, assunto polêmico também entre os membros do ISEB.

A noção da ideologia, embora estivesse presente em boa parte dos estudos dos autores do ISEB, não teve uma atenção mais específica sobre sua teorização acontece na atualidade. O grande problema de parte da produção acadêmica do ISEB foi de não ampliar as discussões e desenvolver uma teoria crítica das ideologias. Isto os levou a cometer grandes equívocos no plano das discussões das ideias, ao não dar maior importância a determinadas conceituações e referências no campo de pesquisa da sociologia, tais como: a articulação dos modos de construção das ideologias, infraestrutura, superestrutura e, também, superestrutura políticoideológica.

Os intelectuais do ISEB, no intuito de buscar legitimação para seus pensamentos e reflexões, incorreram no que Toledo chama de "processo de ideologização da própria ideologia", ou seja, ideologizaram a ideologia que pretendiam formular como verdade daquele momento histórico. (1997, p.61)

\begin{abstract}
A ideologização da produção isebiana vai, assim, residir na hegemonia que se procurava defender para a ideologia do desenvolvimento nacional. Escamoteava-se por completo a existência de ideologias dominantes e ideologias dominadas no interior da formação social, posto que - acreditavam os isebianos - entre as classes sociais que as suportavam não haveria fundamentais contradições de interesses. Não poderia haver ideologias dominantes e ideologias dominadas quando se crê que o projeto de desenvolvimento se identifica com o "projeto de nação". (TOLEDO, 1997, p.62)
\end{abstract}

Fica então garantida à ideologia das classes trabalhadoras, ou seja, à ideologia do desenvolvimento nacional, seu destino, sua verdade, pois a consciência crítica sempre começa e permanece na consciência das classes populares. Para Toledo: 
No sentido forte do termo, não há erro para a consciência das massas, posto que - por uma relativização de caráter historicista ("ser em situação"; "nunca se pode estar acima de seu tempo") seus deslizes e equívocos de percepção nunca são fundamentais ao ponto de desencaminhá-la da realização de seus objetivos históricos. A possibilidade do erro ou da "falsa consciência" corre por conta exclusiva das elites ou dos ideólogos, quando elaboram de forma equivocada os dados fornecidos pela prática coletiva. (1997, p. 62)

Os isebianos acreditavam que pelo fato de as massas adquirirem consciência crítica, supostamente não aconteceriam deslizes capazes de desviá-las de seus objetivos históricos, isso porque isebianos não reconheciam que no interior da formação social existe a submissão de uma ideologia a outra e uma permanente luta de classes, atuando sempre por mais espaço e influência no âmbito da sociedade. O foco do pensamento não recaía nas principais questões a serem vistas, já que os ideólogos não estavam acompanhando a prática coletiva com a devida atenção e ainda culpavam a falta de consciência de nossas elites em todo o processo.

A própria ideologização dos trabalhos do ISEB comprometeu o entendimento da relação existente entre prática científica e prática ideológica. Algumas vezes tudo se reduzia à ideologia e em outros momentos era a ciência que embasava toda a produção teórica e, em outros, as duas aparecem juntas.

A prática ideológica é vista por alguns dos pensadores do Instituto, diretamente vinculada ao conhecimento, à intervenção proposital sobre o real, portanto, será pela ideologia do desenvolvimento que se alcançaria o conhecimento sobre "nós mesmos", sobre o que se pretendia ser.

Se à ideologia cumpre o papel de formular e discutir um sistema de ideias e de pensamentos, à ciência cabe indagar, sempre, em busca de respostas para uma análise adequada dos fatos que se apresentam, de modo a serem discutidos e esclarecidos.

Ao pensarmos a relação entre ideologia e ciência, podemos dizer que a primeira trabalha com a formulação do conhecimento e, como projeto racional, busca construir uma relação dialética com a ação, pretendendo intervir sobre o real, enquanto que a segunda procura pesquisar e compreender tudo o que se relaciona ao universo humano. Contudo, a palavra ideologia passa a apresentar uma séria deformação quando deslocada do seu significado original, desempenhando equivocadamente uma dupla função, pois "tem ela o privilégio de ser simultaneamente, de um lado prática, ação, e, de outro, conhecimento" (TOLEDO, 1997, p.64). 
Vieira Pinto ao definir ideologia, o faz a partir de uma ideologia bem particular, a do desenvolvimento nacional, fugindo de uma visão mais geral sobre ela, ou de concepções que incluam outras manifestações humanas, tais como religião, filosofia, literatura, arte, e as instituições jurídicas, etc. Toledo (1997, p.64-65) observa que a ideologia, no sentido restrito de Vieira Pinto, tem a autoconsciência da nação indissociada de projeto (onde a vontade é determinante e um propósito que a sociedade pensa para si mesma), ou seja, quando a sociedade toma consciência de si mesma (e isso começa com uma consciência individual), ela realiza uma reflexão interna. A consciência coletiva "converte-se assim, de forma natural e espontânea, de simples representação subjetiva 'em projeto e origem de nação"'.

O que distingue a ideologia do desenvolvimento é "a sua natureza não especulativa, é a faculdade de servir de norma à práxis social, como decorrência de sua intrínseca tendência objetivante". Ainda para Vieira Pinto, "a ideologia para ser eficaz e orientar práxis social, o processo de transformação, deve se assentar sobre a compreensão correta da realidade"; mas não pode também ser "um ponto de vista abstrato". (TOLEDO, 1997, p.65)

Toledo enfatiza que o entendimento de Vieira Pinto é que a própria elaboração da ideologia é uma criação do pensamento filosófico, pois está além do campo da economia, sociologia, ciência política, juntas ou isoladamente. A ideologia é baseada em dados trabalhados pelas ciências sociais, que nessa condição são inertes e, por isso, precisam alcançar um outro significado, que não encontram nesse contexto científico. Percebe-se aqui um afastamento do entendimento de Vieira Pinto da relação entre ciência e ideologia, com relação ao de Corbisier, pois o primeiro não aceita que as ciências só sejam possíveis a partir de uma elaboração prévia de um projeto ideológico. Vieira Pinto também considera a ideologia como a reflexão da sociedade sobre ela mesma, uma autoconsciência, uma representação da realidade que tem uma condição subjetiva de reprodução e não transformação do real. Segundo Toledo (1997, p.68), como a obra de Vieira Pinto não pretendia formular uma teoria sobre a prática científica, ela apresenta-se superficial e ambígua. Também, porque não houve uma reflexão teórica sobre os limites entre ciência e ideologia, as práticas científicas foram muitas vezes reduzidas a um fim pragmático e de conveniência.

Serão os "interesses gerais", sempre identificados com os do desenvolvimento nacional, que decidirão sobre a oportunidade ou não dos resultados que advêm da atividade teórica. A ideologia passa, 
assim, a comandar, orientar e legislar acerca do processo do conhecimento objetivo. (TOLEDO, 1997, p.68)

Assim como para os isebianos, a determinação do científico pelo ideológico não é um problema, pois a ideologia do desenvolvimento nacional é autêntica, traduz os interesses da nação. Conforme Toledo,

\begin{abstract}
Afinal, a ideologia do desenvolvimento nacional é autêntica (verdadeira, na sinonímia isebiana), na medida em que exprime os interesses gerais da nação; e isto é um dado objetivo, ou seja, o projeto ideológico é reclamado socialmente e responde às reais exigências da "comunidade" na sua afirmação como totalidade emergente e em seu progresso material. Torna-se, pois, plenamente legítimo, dirão os isebianos, pensar a ideologia (verdadeira) como critério de validação do conhecimento objetivo. Não são os critérios ideológicos determinações exteriores aos da ciência, uma vez que a ideologia autêntica passa a ser investida da própria "dignidade" do saber científico. (1997, p.70)
\end{abstract}

Devemos destacar ainda a preocupação de G. Ramos de se proceder a distinção entre ciência e ideologia. No trabalho de Guerreiro pode-se encontrar a distinção isebiana entre consciência crítica e consciência ingênua, indicando que a primeira seria a responsável pelo surgimento de uma ciência nacional e seria determinante de uma nova atitude dos povos, mudando sua condição de objetos sujeitos da história.

Toledo (1997, p.71) também destaca que os ensaios de G. Ramos denunciavam que o Brasil recebia, de forma acrítica dos principais centros metropolitanos, influências teóricas e metodológicas. Ele frisava que a polêmica em torno das expressões 'ciência natural' ou 'sociologia nacional' não tinha relevância nenhuma, pois nenhuma ciência pode realizar progresso sem ter partido de algo que já era conhecido, portanto, o nacional deveria ser o olhar e a postura do cientista diante dos fatos que se pretende analisar.

A despeito da profundidade das pesquisas realizadas por G. Ramos, o mesmo cometeu um equívoco ao defender o projeto de desenvolvimento nacional como critério para distinguir "saber científico" e "conhecimento ideológico", pois a ideologia do desenvolvimento era sempre tida como verdade do momento histórico, por isso nunca questionada como projeto que representava pequena parcela do país, das classes dominantes. "Novamente, o projeto ideológico aparece como marco decisivo para a sanção das ciências. E, assim, uma vez mais, os limites entre o saber objetivo e os 'interesses nacionais' entram em colapso." (TOLEDO, 1997, p.72) Caminhando um pouco mais na discussão sobre ideologia, Toledo cita Werneck 
Sodré, por este ter uma posição diferente dos demais membros do ISEB. Para Werneck Sodré, a ideologia seria um falso pensamento, mas que desempenha uma função social bem precisa, qual seja, a de justificar e defender os interesses dos grupos dominantes. Não há registro nos trabalhos de Werneck Sodré sobre a urgência de se desenvolver uma ideologia do desenvolvimento (e nem discute uma possível teoria da ideologia) como encontrada nos trabalhos dos demais isebianos. Sodré defendia que o nacionalismo era uma prática política adequada ao momento da formação social brasileira, mas não se referia a uma ideologia, pois, segundo ele, o nacionalismo "não foi inventado, não surge da imaginação de uns poucos, nem vive da teoria, mas da prática", melhor dizendo, o nacionalismo é uma "solução natural" e espontânea, pois não traduz interesses particulares, como as ideologias em geral. (1997, p.72-73)

As distinções foco das discussões isebianas anteriormente abordadas têm como pano de fundo a questão da alienação, um conceito filosófico, de cunho existencial. Portanto, a alienação é o conceito central dos estudos do ISEB, mesmo porque as mudanças colocadas em curso pelo desenvolvimento poderia por um fim na alienação e, consequentemente, dar autonomia à nação e promover a consciência crítica.

O conceito da alienação esteve presente na maioria dos trabalhos do ISEB, mas advertiam que "com isso não se estava aceitando os postulados idealistas e ahistóricos de algumas variantes daquele movimento filosófico". (TOLEDO, 1997, p.82)

O ISEB denominava o subdesenvolvimento do Brasil (e de outras nações) como semicolonial e não colonial, no qual a autonomia política seria doada ou conquistada, uma estrutura em sua totalidade alienada, tanto a econômica como a superestrutura ideológica e cultural. Toledo, citando Corbisier:

\footnotetext{
Embora as relações entre tais instâncias não sejam de caráter "mecanicista", mas "dialético", aceita-se o postulado segundo o qual a alienação implica a dependência econômica ou, numa outra fórmula, "a independência econômica é condição necessária, embora não seja condição suficiente da emancipação [desalienação] cultural." (1997, p.83) (Grifos do autor)
}

Com a formulação acima, insere-se mais um conceito muito presente nos ensaios isebianos, o conceito de "dependência", utilizado tanto para definir a situação colonial, como a situação de subdesenvolvimento ou semicolonialismo que nesses contextos, é identificada com alienação. Para os isebianos, a dependência é 
entendida no âmbito da nação, ou seja, a dependência dos países subdesenvolvidos está relacionada às suas ligações externas, à sua posição de "periferia" ou de "proletariado externo" do mundo desenvolvido. Tanto a estrutura colonial como o proletariado externo, dependentes e ocupando uma posição marginal, são figuras importantes para o funcionamento e a expansão do sistema global de dominação, do qual fazem parte. (TOLEDO, 1997, p.83)

Toledo também destaca a visão de $\mathrm{C}$. Mendes sobre dependência, que via a relação de expropriação das empresas capitalistas com suas periferias se identificar mais pela marginalidade de como acontece essa exploração do que pela perversa utilização de sua mão de obra. Para o ISEB, o termo proletariado não tem relação com o conceito histórico de classe social, mas seu uso é utilizado para representar a situação semicolonial ou subdesenvolvida. Como o conceito de classe social não fazia parte da análise da dependência e alienação pensava-se em duas figuras, a metrópole e a periferia, e uma relação dialética de dominação e servidão. Uma colônia não tem "ser próprio", seu ser é sempre do "outro", numa condição em que escravos e colônias ficam reduzidos a objetos e coisas, no caso dos primeiros, e sujeito e liberdade, no caso das colônias. Indo além dessa relação de dialética do reconhecimento, Corbisier identifica uma economia de complementaridade, ou seja, a colônia exportando matéria-prima, o "não-ser", e importando da metrópole "o ser", os produtos acabados. (1997, p.84-85)

De forma que a perspectiva do desenvolvimento econômico traz uma esperança de que aconteça uma ruptura com a estrutura subdesenvolvida, propiciando a conquista da autonomia e, por conseguinte, a realização, de forma a inserir estes países numa nova etapa de ação do seu processo histórico e onde o trabalho passa a ser visto como um processo de interação com a natureza, transformado-a e obtendo o domínio sobre diversas técnicas que permitem obter recursos para o seu fim.

O trabalho, definido nos termos do pensamento existencial, é
entendido como um "modo de ser do existente humano". O homem,
para conservar sua existência, necessita atuar sobre a natureza,
transformando-a e dominando-a. Assim fazendo, cria o seu ser
"porque estabelece com a natureza circundante e com seus
semelhantesrelações que são produtos de sua capacidade inventiva".
Pelo trabalho, o homem se apossa da natureza, descobre as leis que
a regem, as propriedades das coisas que a compõem e deles se
utiliza para o seu proveito. (TOLEDO, 1997, p.85) Ainda segundo Toledo, o que existia de humano no trabalho e expressava a essência do homem, que seria a exploração da natureza de modo igualitário por todos os 
homens, é pervertido no curso da história dos próprios homens, quando estes passaram a explorar seus semelhantes e não mais a natureza, resultando, como observa $H$. Jaguaribe, um estado social injusto e desumano e que deveria ser corrigido. (1997, p.86)

Vieira Pinto chama a atenção para a alienação do trabalhador nas etapas mais avançadas do capitalismo e em num país subdesenvolvido aconteceria uma dupla alienação, por ela ser uma questão própria do capitalismo e pelo fato de o trabalhador viver em um país atrasado, dependente e explorado internacionalmente, o que faz com que a alienação seja compartilhada por toda nação. Vieira Pinto dizia que o homem de um país subdesenvolvido só se realizaria se conseguisse desenvolver plenamente seu mundo. (TOLEDO, 1997, p.86)

Frequentemente, porém, Vieira Pinto ao afirmar a dominação da alienação internacional do trabalho, chegará a dissolver e mesmo eliminar a contradição originária do sistema capitalista (capital $\mathrm{x}$ trabalho). O desenvolvimento econômico, pura e simplesmente, ao permitir a emergência da consciência nacionalista autêntica, representaria, simultaneamente, não só a liberação nacional como também a de todos os grupos sociais presentes no interior da nação. (TOLEDO, 1997, p.87) (grifos do autor)

Essa visão indica que o processo de transformação do subdesenvolvimento em desenvolvimento ou a passagem do estado de alienação retira-se a determinação concreta desses conceitos. Vieira Pinto também entendia que somente ao atingir um grau de consciência nacionalista, gerado por um determinado patamar de desenvolvimento econômico, é quando o país encontra os meios para superar suas diferentes formas de alienação. Portanto, desenvolvimento econômico e seu análogo, a consciência nacionalista, seriam a representação da desalienação proletária e do proletariado histórico, tanto no nível econômico, como no político e cultural.

\footnotetext{
Em outras palavras, o desenvolvimento econômico, realizado em moldes nacionalistas, representaria o fim do estado de alienação na medida em que a nação - e todos os seus grupos sociais capturariam a essência ou "o ser histórico" até então possuído pelas nações metropolitanas ou desenvolvidas. (TOLEDO, 1997, p.89)
}

Porém, o fato de se pensar o subdesenvolvimento em termos de nação dependente e não como capitalismo dependente e também não considerar o desenvolvimento como a realização do capitalismo de periferia levou a se concluir que "o desenvolvimento econômico da nação representaria o fim de todas as suas dependências ou alienações". (TOLEDO, 1997, p.89) 
Então, passa-se a reconhecer o subdesenvolvimento como um limitador para o homem encontrar sua essência, ser realmente humano, e entender que o desenvolvimento econômico deveria ser pensado como um estágio inicial de um novo regime de produção.

Importante notar que o desenvolvimento é muito exaltado por Vieira Pinto, pois com ele o trabalhador teria sempre benefícios, não correria nenhum perigo, a não ser a interrupção do próprio desenvolvimento, ao passo que o desenvolvimento seria contra a classe exploradora, mesmo que durante algum tempo ela percebesse um aumento dos seus lucros. $\mathrm{O}$ autor também considerava a possibilidade de, se fosse superada a primeira etapa do desenvolvimento nacionalista, a conquista do poder político pelas massas seria inevitável. Era também previsto o declínio de todos os aproveitadores do trabalho das classes operárias. Vieira Pinto considerava o desenvolvimento econômico como o primeiro estágio para um "novo" regime de produção, sem que, no entanto, tenha explicado qual seria esse "novo" regime, dando margem a se pensar que o capitalismo não seria mais a única forma de organizar a vida social.

\begin{abstract}
Permanecendo ao nível de um tratamento filosófico (tributário de uma antropologia existencial-marxista) da questão da alienação do trabalho e tomando a alienação nacional como a contradição fundamental, Vieira Pinto não conseguirá sofrear seu entusiasmo ao defender a necessidade do desenvolvimento econômico. Este parece se transmutar na chave da superação de todas as alienações e vicissitudes da existência dos países periféricos. (TOLEDO, 1997, p.91-92) (grifos do autor)
\end{abstract}

A cultura no subdesenvolvimento também será subdesenvolvida, com produções pobres e pouco autênticas, pois não enquanto perdura o subdesenvolvimento ou semicolonialismo, não há espaço para existir projeto de "destino histórico independente", já que suas produções têm a marca da alienação. Assim, se não existe um projeto próprio, adota-se um projeto de outro, fazendo da cultura um subproduto, um reflexo, da cultura metropolitana:

Dirá Vieira Pinto - a partir da aceitação dos postulados da "teoria do reflexo" - que a consciência da nação atrasada é o "reflexo do reflexo"; reflete este não à sua realidade, não ao seu mundo objetivo, pois, sendo este pobre, subdesenvolvido, está "completamente inabilitado para refletir, de qualquer modo, a realidade, ou seja, para alcançar a verdade para si, tanto no que se refere ao mundo dos outros, quanto no que diz respeito ao seu próprio". Se refletisse fielmente a sua realidade, a consciência do mundo subdesenvolvido perceberia este como sendo dependente, dominado, alienado; mas 
isso é precisamente o que tal consciência não pode admitir. (TOLEDO, 1997, p.94)

A complexa questão cultural e a relação de dependência que o país teve por um longo período com as metrópoles, ocupa grande parte das análises do ISEB. Corbisier, por exemplo, considerava que a cultura, como resultado da transformação da natureza por meio do trabalho humano, dependia de um projeto, que não existia no estado de dominação. Assim, o subdesenvolvimento se encarregava de reproduzir um modelo cultural nada natural da metrópole, resultando em uma cultura que não Ihes pertencia. A alienação cultural a que se sujeitava nossa elite pensante, chamada de transplantação por Werneck Sodré e de heteronomia para G. Ramos, colaborava para sedimentar uma cultura que não dava identidade à nação. Mas é importante que se diga que a própria lógica do sistema e a imposição da metrópole não conferiam outra saída para que a situação fosse diferente. A transplantação seria a "ideologia do colonialismo". (TOLEDO, 1997, p.94)

Muitos estudiosos do período consideravam essa alienação cultural das elites durante a fase colonial como um mal, um vício de nossa formação, proveniente da ingenuidade ou malícia do povo brasileiro. Vieira Pinto considera que não havendo um pensamento crítico, também não poderia se considerar que o pensamento dominante na colônia fosse alienado e mais, somente com base nos padrões atuais da vida brasileira é que se pode dizer que toda e qualquer manifestação que aceite sem criticar os modelos estrangeiros será considerada alienada do ponto de vista cultural. Os isebianos, portanto, buscavam apontar a falta de fundamento científico de alguns estudiosos brasileiros que procuravam definir a essência do povo brasileiro. Segundo Toledo:

Todas as ideias a nosso respeito, dirão os isebianos - e aqueles acima que definiriam o nosso "ser" aqui se incluem - nada mais faziam do que refletir (inconscientemente que fosse) as formulações do pensamento alheio ou da cultura dominante. [...] Na ausência (e impossibilidade) da consciência ou do pensamento críticos, aceitavamse passivamente as categorias e representações da nação dominante acerca da própria situação do dominado. (1997, p.97)

Um pensador de um país periférico que buscasse uma interpretação sobre si mesmo, sobre a realidade de seu mundo, acabaria por concluir que o conhecimento que procurava já se encontrava pronto. A aceitação desse conhecimento vai, então, impedir a tomada de consciência de sua realidade globalmente alienada e assim sustentar as relações de dominação. Toledo: "A dependência deve ser a verdade do 
mundo subdesenvolvido. Esta é a ordem natural imposta para o perfeito funcionamento e realização do sistema." O autor também chama a atenção para o fato de que o pensamento metropolitano não chegava às áreas periféricas diretamente, mas intermediados pelas classes dominantes que aceitavam "seu papel de porta-vozes dos interesses estrangeiros em seus próprios países". (TOLEDO, 1997, p.97)

Isto ilustra como a forma de dominação era exercida e os motivos para a total incapacidade de se elaborar um projeto independente de construção da sua identidade cultural, pois no interior da própria nação operavam formas discursivas, sutis, com plena condição para exercer o pensamento dominante, reforçando visões e conceitos oriundos da metrópole.

Mas os lemas isebianos "tudo é colonial na colônia" e "tudo é subdesenvolvido no subdesenvolvimento" limitou as pesquisas do Instituto, que deixou de considerar importantes problemas importantes para se fazer uma criteriosa análise da realidade social. Devemos destacar que a abordagem do ISEB ficava sempre circunscrita ao nível econômico, que daria conta de toda determinação do universo social. Nessa linha de pensamento então viria a conclusão de que "tudo é desenvolvido no país desenvolvido", ou, como entendia Vieira Pinto, a nação desenvolvida é sempre dotada de consciência crítica.

Mostrou-se, anteriormente, como toda a produção ao nível do pensamento está centrada sobre a noção de consciência crítica. Será esta que possibilitará - desde que tornada consciência social - o surgimento da cultura, da política e da ideologia autênticas. A consciência ou pensamentos críticos, porém, não vão se verificar, senão episodicamente, no interior da colônia ou da situação semicolonial. (TOLEDO, 1997, p. 98)

Os isebianos então buscavam mostrar como antes da arrancada industrial, intelectuais de nosso país formularam pensamentos críticos bastante assertivos sobre a realidade brasileira, ao mesmo tempo em que assentiam com as mais variadas teorias vindas da metrópole, repletas de preconceitos. Importantes autores também se perdiam nessa contradição, já que pensavam de acordo com seu tempo, que era marcado pela dominação e alienação. Essa situação, inclusive, impediu que o próprio ISEB realizasse uma pesquisa mais aprofundada e sistemática sobre o patrimônio cultural brasileiro, considerado um depósito de trabalhos intelectuais subalternos.

Segundo Toledo, alguns trabalhos do ISEB eram guiados pelo "relativismo e 
mecanismos metodológicos". Pensava-se que somente a própria nação metropolitana é que teria o poder de ter sobre si mesma um conhecimento objetivo e este também só a ela pertenceria, esse conhecimento seria parte de seu estágio de desenvolvimento e que não teria nenhuma relação com as demais "formações sociais", neste caso, as subdesenvolvidas. A verdade então era vista como tendo uma relação direta com o desenvolvimento e, desse modo, o conhecimento científico teria uma ordenação geográfica e social. (1997, p.99)

Havia uma recusa de se aceitar a existência de luta de classes na formação subdesenvolvida que não permitia aos isebianos colocar a luta ideológica na pauta das discussões. Segundo Toledo:

\footnotetext{
Ideologias dominantes e ideologias dominadas, como expressões das classes dominantes e das classes dominadas, nunca são pensadas como constituindo o núcleo mesmo da esfera ideológica dentro das formações sociais capitalistas, sejam elas "atrasadas" ou desenvolvidas. (1997, p.100)
}

Portanto, naquele momento, a luta ideológica não era vista como combate entre as ideologias dominantes e as dominadas, mas apenas dentro da classe dirigente. Os isebianos não pensavam "quais seriam as funções e o estatuto da ideologia na sociedade desalienada, 'pois ninguém está acima de suas circunstâncias e de seu tempo'”. (TOLEDO, 1997, p.101)

As massas das nações atrasadas, que não participavam da cultura dominante e da vida política, não estão sujeitas à alienação como as classes dirigentes e, por isso, chegam pelas mãos do desenvolvimento econômico na consciência nacionalista. $A$ construção e a consolidação de uma ideologia dominante nacionalista seriam lideradas pelas massas proletárias e não, ao contrário do que se poderia pensar, pela burguesia.

É importante destacar que o ISEB elegeu o nacionalismo como a ideologia autêntica daquele momento histórico, partindo de suposições teóricas do que eles conheciam da estrutura das relações de classes que existiam na formação social brasileira depois de 1930, considerada pré-desenvolvimentista e na fase de transição. Os estudos partiriam de teorias de classes e inclusive das contradições sociais existentes para fundamentar e legitimar a ideologia nacional-desenvolvimentista, que pautou o pensamento do ISEB durante todo o governo de JK, embora não se tenha encontrado na produção do Instituto qualquer trabalho mais consistente, do ponto de vista teórico ou empírico, sobre o problema das classes sociais. 
Os isebianos viam na sociedade brasileira do pós-1930 a existência de dois grupos: os "dinâmicos e produtivos" e os "estáticos e parasitários", que acomodavam pedaços das três classes principais: burguesia, classe média e proletariado. Ajudar ou atrapalhar o processo de industrialização que chegava ao país foi o critério para que os isebianos dividissem essas classes sociais em dois setores: o tradicional, que agregaria a classe fundiária, a burguesia mercantil, a classe média não-produtiva e partes do proletariado, e o moderno, que agregaria a burguesia industrial, o proletariado urbano e rural e a classe média produtiva, e que aparece com a queda da estrutura colonial e a chegada da industrialização. (TOLEDO, 1997, p.133-134)

\begin{abstract}
As duas primeiras do setor moderno, no processo de consolidação do capitalismo na periferia, desempenharão, respectivamente, as funções de "controle dos bens de produção e prestação de mão de obra", enquanto as classes médias produtivas forneceriam os quadros técnicos especializados exigidos pelo desenvolvimento industrial. (TOLEDO, 1997, p.134)
\end{abstract}

A deposição do governo de Washington Luiz marca definitivamente o início de um período de grandes mudanças para o país, como a deposição da República Velha, o fim da hegemonia da política "café com leite" e a ascensão de outro grupo ao poder liderado por Getúlio Vargas, que iria então imprimir sua marca pessoal na forma de administrar o Estado brasileiro, impondo a modernização de suas estruturas como já foi mencionado anteriormente.

Os isebianos se esforçaram para entender como os diferentes estratos da formação social brasileira se comportaram ao se alinharem ao setor moderno que aparece com as mudanças econômicas no processo de transformação urbana iniciada a partir da década de 1930 e os efeitos da posição dos tradicionais, a antiga ordem vigente como os cafeicultores e usineiros do açúcar, que passaram a criar uma série de entraves após perderem o poder e o espaço político que tinham desde o Império. Houve um embate entre as classes do setor moderno em ascensão no que dizia respeito ao econômico, os outros grupos sociais, pois o "parasitismo social" herdado do tempo colonial impedia o protagonismo dos interesses progressistas ou industriais, fazendo com que interesses arcaicos permanecessem presentes na nossa sociedade e contaminassem as relações sociais. (TOLEDO, 1997, p.134) Jaguaribe entendia que havia parasitismo na classe média, isso em razão de os quadros do funcionalismo estarem aquém do necessário para oferecer um serviço adequado ao público, em setores da classe burguesa empresarial, beneficiados por medidas que protegiam e subvencionavam negócios pouco produtivos e também um parasitismo social, 
relacionado às classes trabalhadoras, que tinham hábitos e instituições de proteção ao trabalho, que vinham do período do subdesenvolvimento, quando a demanda era menor que a oferta de trabalho.

Já Werneck Sodré simplifica o esquema de classes sociais, tendo ele os seguintes estratos: classe proletária urbana (politizada e decorrente do processo de industrialização); classe média ou pequena burguesia (emerge do cenário político pós-1930); a burguesia, dividida em dois eixos, a burguesia nacional e a grande burguesia (interesses vinculados aos mercados externos), e a classe dos proprietários territoriais (latifundiários), que não aceitam nenhuma reforma que vá afetar seus direitos e, principalmente, seus privilégios. Ainda segundo Toledo:

Nos textos isebianos não se vai além de tais esquemas, não se
encontrando igualmente qualquer reflexão teórica acerca do tema
das classes sociais. Estas são invocadas pela análise apenas para
ressaltar a contradição dominante ou principal da sociedade brasileira
e justificar o projeto ideológico nacional-desenvolvimentista. (1997,
p.135) O que havia nos trabalhos do ISEB era um entendimento subtendido das classes sociais, de um modo geral sendo identificadas em função de critérios basicamente econômicos. Segundo Toledo, é C. Mendes quem dedica um espaço para discutir o tema dentro do Instituto, que considerava que no subdesenvolvimento não se poderia falar em classes sociais, mas sim em "classes em projeto". Mendes entendia que as classes sociais estariam relacionadas às situações econômicas que trariam mobilidade social por meio das ofertas do mercado de trabalho e que, na fase inicial do desenvolvimento, ainda não eram percebidas as contradições entre o capital e o trabalho, portanto não seria correto falar em classe social. Portanto,

Para C. Mendes, como em G. Ramos, as classes sociais são inerentes à implantação do capitalismo desenvolvido (tal como ocorre hoje nas situações metropolitanas) e têm como condição a existência da consciência de classe (enquanto reivindicações econômicas). (TOLEDO, 1997, p.136)

G. Ramos via que os principais conflitos existentes na sociedade brasileira eram os que expressavam na contradição "estagnação" e "desenvolvimento" representados por classes sociais e "nação" e "antinação", que significaria um processo de personalização da história de um lado e de alienação de outro. Poderiam ser facilmente identificadas as forças que eram favoráveis ao desenvolvimento nacional, o mesmo não acontecendo com os setores que constituíam o polo antinação, que 
criavam dificuldades para a implantação do projeto nacional-desenvolvimentista, que tinham o imperialismo seu mais importante agente. (TOLEDO, 1997, p.137)

Era consenso no ISEB que o polo "nação" seria representado pelos setores produtivos existentes nas três classes que constituem a formação social brasileira: burguesia, classe média e proletariado e o que existia de não producente e decadente nessas mesmas classes estariam no polo "antinação". Esse consenso decorre também da visão de que a contradição capital $x$ trabalho quando a sociedade brasileira atingisse o estágio desenvolvido, ou seja, atingisse o capitalismo avançado que eliminaria a própria contradição do sistema. Nas palavras de Toledo:

Enquanto tal não ocorrer, será alienada toda e qualquer posição
política que privilegie esta segunda contradição como a principal no
todo social. Implícita também está nestas considerações a afirmação
do desenvolvimento, em termos capitalistas, como a via possível e
verdadeiramente superadora da contradição nação x antinação. (1997,
p.138)

Como podemos perceber entre os isebianos, uma visão muito restrita e limitada na compreensão de que se refere apenas a atribuir toda a problemática ao Imperialismo como limitador da perspectiva do proposto projeto do nacional-desenvolvimentismo e como uma exigência externa à nação.

Autores como C. Mendes e G. Ramos viam que o uso de termos tais como centros dominantes ou metropolitanos indicavam simplesmente a atuação dos capitais estrangeiros na economia nacional, mas que não chegavam a assumir o significado de forças objetivas internacionalmente dirigidas a obstar o desenvolvimento da nação subdesenvolvida. A única opção no imperialismo era uma associação dos setores nacionais ligados ao exterior, ou seja, não se concebia a "associação entre o capital estrangeiro e o empresário industrial nacional". Werneck Sodré também tem uma posição frágil, quando coloca ao lado do Imperialismo a "grande burguesia" que tinha interesses nos mercados externos e a classe dos proprietários. (TOLEDO, 1997, p.139)

Mesmo Vieira Pinto, apesar de ter um trabalho um pouco diferente dos demais, apresentava um estudo sobre uma teoria de classes bastante limitada, como a de seus pares. Vieira Pinto apresenta sua "teoria da pluralidade de contradições", na qual o papel de contradição principal (pois entende que existam outras) é ocupado pela oposição entre países subdesenvolvidos e os desenvolvidos. Tempos depois, o autor vai rever a tese da unidade nacional (que abriga a problemática nação $x$ antinação), na qual o imperialismo era tido como um agente ou força externa, que o 
coloca no interior da própria nação. Vieira Pinto também recusa a ideia de que ao imperialismo estejam associados unicamente os "setores decadentes e improdutivos" das classes sociais e vai então incluir também a burguesia. (TOLEDO, 1997, p.141)

Continuando, Vieira Pinto, vai se aprofundar na discussão que buscava entender o lugar que as massas trabalhadoras (que o autor considerava como força revolucionária) ocupavam nas contradições sociais.

A nosso ver, um dos pressupostos básicos do "populismo teórico" da obra de Vieira Pinto encontra-se na idílica afirmação da "unidade natural" e indestrutível das classes trabalhadoras (rurais e industriais). Fica, assim, de imediato, garantida a sorte do projeto nacionalista, na medida em que a decisão da massa proletária é irrevogável na luta que empreende contra o imperialismo e seus agentes internos. (TOLEDO, 1997, p.142)

E ainda:

O mesmo, porém, não ocorre em relação às classes dirigentes. Como estas só serão "ganhas" pela consciência nacionalista, através de um intensa luta ideológica, às vezes se encontrarão divididas no interior do país subdesenvolvido. (TOLEDO, 1997, p.142-143)

Haveria, desta forma, uma estratégia a ser desenvolvida pelo proletariado para alcançar a superação do subdesenvolvimento, que se daria pela eliminação do domínio estrangeiro sobre a economia local, que supostamente eliminaria a contradição existente entre as classes.

Mesmo que o nacionalismo tenha sido uma ideologia hegemônica no ISEB no governo JK, isso não significa que havia um consenso ou uma única ideologia isebiana, mas sim vários entendimentos sobre ele. Mas a afirmação de $H$. Jaguaribe acerca do assunto conseguiu a aceitação, mesmo que em linhas gerais, dos demais membros.

Segundo Toledo, H. Jaguaribe afirmava que o nacionalismo constitui-se "no propósito de instaurar ou consolidar a aparelhagem institucional necessária para assegurar o desenvolvimento de uma comunidade". O nacionalismo seria tanto um fenômeno basicamente histórico-social, como uma ideologia "racionalizadora do comportamento político-social". (1997, p.148)

A ideia de que a ideologia nacionalista era um projeto global dominante entre os isebianos. Toledo afirma que a ideologia global ao se tornar hegemônica, isto é, quando os setores que a compõem, principalmente a burguesia industrial, passasse 
a ter controle e poder político, ela conquistaria os setores estagnados, trazendo-os para atuar em prol do desenvolvimento nacional. Assim, a ideologia nacional passará a ser um "denominador comum mínimo" para a luta do que existe de nacional em toda a sociedade brasileira. (1997, p.152-153)

Porém, os isebianos não viam que a burguesia, mesmo sendo uma classe dominante, não havia se tornado uma classe dirigente, pessoas que entendessem que o processo econômico é muito mais amplo do que os interesses de seus próprios negócios. O que acontecia então, na visão de G. Ramos, era que:

Em sua arrancada para o desenvolvimento, o país se vê às voltas com o sério problema de que as "forças políticas e o poder econômico estão nas mãos de pessoas jurídicas e físicas que, em larga escala, não têm consciência sistemática do projeto pressuposto por sua condição". (TOLEDO, 1997, p.153)

H. Jaguaribe chama a atenção para o fato de que se os empresários tivessem abraçado a causa do governo JK, explicitada em seu Plano de Metas, e também substituído a "política de clientela" pela "política ideológica", teríamos podido organizar um novo Estado, mais funcional, planejador e capaz de promover o desenvolvimento do país. O que se pode observar é que, embora a ideologia nacionalista fosse pouco a pouco conquistando mais adeptos na sociedade brasileira, o nacionalismo ainda seria uma ideologia parcial enquanto continuasse a existir a contradição entre nação x imperialismo. (TOLEDO, 1997, p.153-154)

O Instituto, criado para disseminar cultura e preparar uma elite capaz de ajudar no desenvolvimento do país, vai se posicionar sobre os resultados da política desenvolvimentista introduzida pelo governo JK. Isso não significa que dos trabalhos do ISEB constasse um estudo profundo e sistemático do período desenvolvimentista. Mesmo gozando de autonomia prevista em seu estatuto, os ensaios publicados por alguns autores do ISEB apresentavam algumas críticas e também elogios sobre as realizações do governo.

Com isso, se pretende dizer que, se no seu início interessava ao governo JK a utilização do ISEB "como instrumento ideológico" para a propaganda do desenvolvimentismo, aos poucos esse interesse será atenuado em razão de uma certa discrepância quanto à compreensão que se passa a ter do desenvolvimento nacional (suas contradições, limites, dificuldades, etc.) (TOLEDO, 1997, p.158)

Vieira Pinto, inclusive, chegou a criticar duramente o desenvolvimento nacional por conta do que ele chamava de entreguismo e da pouca consciência nacionalista do 
governo JK. Vieira Pinto, parece, não atentava para o fato de que no período de 1956 a 1960, sob o governo de JK, a internacionalização da economia foi a condição para a expansão industrial do Brasil.

\begin{abstract}
$\mathrm{Na}$ ausência de análises acerca do novo caráter da economia brasileira, a partir da expansão industrial da década de 50 [1950], e permanecendo-se ao nível dos "princípios nacionalistas", não puderam os isebianos perceber em toda a sua extensão que o desenvolvimentismo, na vigência do capitalismo, só podia se realizar por meio de um crescente fortalecimento das relações de dependência entre as metrópoles e as periferias, no qual a internacionalização da economia era uma das suas raras expressões. Dito em outros termos, o "entreguismo" da política econômica não era percebido como tendo um "caráter estrutural". (TOLEDO, 1997, p.161)
\end{abstract}

Os pressupostos da ideologia desenvolvimentista estavam focados na formação de um mercado consumidor que permitisse um crescimento interno e assim gerar uma ruptura com o mercado exterior, de modo a fazer o Brasil entrar em uma nova fase do capitalismo nacional autônomo, transferindo os principais processos decisórios para o próprio país. A oposição à ideologia do desenvolvimento que então se via tinha foco no combate ao imperialismo, que colocaria em risco a soberania nacional do país, por incentivar a internacionalização da produção. A solução natural que se colocava era se optar pelo nacionalismo, um outro sistema de defesa dos interesses do país, e capaz de realizar uma grande transformação na sociedade brasileira, bem como de implementar o desenvolvimento econômico (industrial), sem se deixar levar pelas formas de alienação (dependência) a que nossa sociedade esteve submetida ao longo dos séculos.

Na realidade o país passava a fazer parte da estrutura de desenvolvimento capitalista periférico, de forma que a estrutura de produção estaria sendo operada no limite do mercado interno, pois somente isto atenderia aos interesses momentâneos dos detentores do capital, estratégicos para a transferência do lucro para as matrizes.

Toledo destaca dois estudos críticos feitos por Osny Pereira Duarte, mas que trouxeram importantes considerações para o entendimento do período pósdesenvolvimentista, referentes a 1960 em diante, que incluem o próprio período de JK, como também o período dos governos de Jânio Quadros e João Goulart, quando o ISEB começa a rarear sua produção, até que vai ser finalmente extinto.

Osny Duarte faz, em 1963, um balanço do ISEB, até aquele momento, em que afirma ter o Instituto nascido da contradição entre o imperialismo e a burguesia nacional, no período da industrialização do Brasil. Segundo ele, a burguesia pretendia 
transitar em caminhos que não o do imperialismo e, tampouco, o da socialização do país.

Ainda segundo Osny Duarte, o ISEB já inicia suas atividades comprometido com a ideologia oficial do governo JK, uma imperfeição que vai se corrigir tempos depois, quando demonstra as promessas que não foram realizadas pelo desenvolvimentismo. Osny Duarte afirmava que o desenvolvimentismo, como ideologia burguesa da época e como o pensamento que criou o ISEB, foi completamente rejeitado pelo próprio Instituto quatro anos depois de sua instituição, concluindo que o desenvolvimento só faria com que as classes dominantes ficassem ainda mais ricas e as oprimidas ainda mais pobres. Na visão de Osny Duarte o trabalho do ISEB seria, daquele momento para frente, estudar profundamente o que seriam as "reformas de base" para apontar um caminho para que elas fossem implementadas. Toledo destaca que

Embora, como ressaltamos, possa-se questionar a representatividade e o valor do texto enquanto peça fundamental para o desvendamento do pensamento ideológico isebiano na sua fase pós-desenvolvimentista, deve-se, contudo, ponderar que o autor, além de professor da instituição, havia sido designado especialmente pela sua direção para pronunciar aquela aula inaugural. Depreendese, assim, que representa, pelo menos, certa parcela do pensamento isebiano da época. (TOLEDO, 1997, p.162)

O crescimento industrial do Brasil contrastava com a presença de grandes latifúndios improdutivos e até "formas feudais" de produção no setor agrícola, por isso que as manifestações a favor das "reformas de base", que tinham como uma de suas principais reivindicações a reforma agrária, cresciam no governo de Goulart e acabaram repercutindo no ISEB, sensibilizando boa parte de seus integrantes e, segundo Osny Duarte, a política de reformas de base seria "a única 'revolução' compatível com o momento histórico".

Impõem-se medidas que venham reparar as "injustiças" que o desenvolvimentismo teria cometido contra o "povo sacrificado". Tratase, pois, de fazer a revolução, mas esta - "antes que o povo a faça", na matreira boutade do político mineiro - deverá vir "de cima", do poder que tomou a iniciativa de realizá-la, em nome das massas, através das reformas de base. A Revolução, assim, tal como antes, consistirá basicamente em "alterações no processo objetivo" que não chegarão, contudo, à transformação do "regime vigente". Assim, o movimento pelas reformas de base - que se constitui numa das práticas políticas do período 61-63 [1961-1963] - parece ter também ecoado no ISEB. (TOLEDO, 1997, p.163) (grifos do autor) 
A defesa de reformas que pleiteavam mudanças nas estruturas da sociedade brasileira deixa o ISEB em uma difícil situação, pela diminuição do apoio governamental, prejudicando suas atividades. Um livro publicado já na fase final do ISEB, de Wanderley Guilherme, apontava a falta, no Instituto, de análises sobre as contradições sociais do Brasil.

Mesmo algumas críticas não diminuem a importância do ISEB para a compreensão da formação histórica da sociedade brasileira, ainda que o Instituto tenha cometido alguns erros, segundo W. Guilherme, nas suas análises dos "fenômenos" naturais do próprio capitalismo. Mesmo que o ISEB tenha procurado compreender a ideologia desenvolvimentista do governo JK, o Instituto sempre demonstrou independência em relação ao governo.

Toledo, entretanto, aponta dois erros cometidos pelos que ele chama de "ideólogos do desenvolvimento", que a seguir cito:

A sociedade brasileira não seria constituída pela justaposição de dois sistemas distintos, radicalmente separados e antagônicos ("antes resulta essencialmente do amálgama de todos os elementos em presença, embora heterogêneos e conflitantes"); o imperialismo não se constitui em polo externo; a contradição principal, pois, está incluída no interior da própria nação. (1997, p.165) (grifo do autor)

W. Guilherme entendia que a defesa do capitalismo nacional por meio da ideologia do desenvolvimento seria um contracenso, já que dentro do próprio sistema da formação social brasileira é que residem as contradições que deveriam ser decifradas. O autor indica que a contradição principal do sistema capitalista subdesenvolvido brasileiro seria a limitação do valor do trabalho nacional no mercado internacional.

A contradição principal do capitalismo brasileiro cifra-se, assim, na oposição entre a expansão da força do trabalho ("fenômeno nacional") e as condições de consumo dessa mesma força de trabalho ("limitada internacionalmente") (TOLEDO, 1997, p.166)

Poderíamos dizer que não foram alcançados os pressupostos e os princípios da ideologia nacional-desenvolvimentista, resumidos por C. Mendes. Seriam eles:

a - Ao superar o complexo colonial, o desenvolvimento integraria naturalmente os interesses das classes sociais; $b$ - o desenvolvimento industrial implicaria a superação da "dependência entre os regimes periféricos e as economias dominantes do mundo contemporâneo"; c - 
os efeitos do desenvolvimento alcançariam toda a coletividade, havendo uma "transformação geral das estruturas da vida social". (TOLEDO, 1997, p. 175)

O tempo mostrou, de acordo com $\mathrm{C}$. Mendes, que o desenvolvimento do país se deu a custa do "ônus do seu financiamento e a apropriação dos benefícios" que planejava obter; que o custo desse desenvolvimento se deu pelo sacrifício das classes menos favorecidas, que viam sua renda reduzida e o não-atendimento de suas necessidades mais básicas; que a expansão industrial reforçou a dependência metropolitana.

No seu último período, o "esquerdismo", alinhado à linha político-ideológica do PCB anterior a 1964, foi um pensamento dominante no ISEB. Importante lembrar que o período de 1960 a 1964 é marcado por uma intensa turbulência no plano político: renúncia de Jânio Quadros; reação militar contra a posse de seu vice-presidente João Goulart que se encontrava na China; a solução negociada do Parlamentarismo; e a volta do Presidencialismo. É bom destacar que o presidente João Goulart era tido como uma figura negativa por diversos setores da sociedade mais conservadores, devido ao seu passado de ligação com o sindicalismo trabalhista, oriundo da estrutura varguista.

Assim, em razão do aumento da instabilidade e fragilidade do governo, o temor da anarquia e que as forças de esquerda tentassem um golpe que conduzisse o país ao comunismo, já que a lembrança da revolução cubana ainda estava presente, eram cada vez mais comuns ações por parte de setores conservadores, que se articulavam e conspiravam contra o governo Goulart, com a ajuda do Instituto de Pesquisas e Estudos Sociais (Ipes) ${ }^{20}$, pois para estes grupos era evidente a falta de habilidade por parte de Goulart na condução da situação política do país.

\footnotetext{
20 O Ipes foi fundado em 1961 e constituído por membros das elites empresariais favoráveis à abertura do país ao capital estrangeiro e que faziam oposição ao governo Goulart. Na verdade o nome do Instituto (Pesquisa e Estudos Sociais) era uma forma de disfarçar o real e meticuloso projeto que ali era gestado para desestabilizar o governo e assim abrir caminho para o projeto econômico-político das elites. Entre 1962 e 1964, o Grupo de Opinião Pública do Ipes produziu 14 filmes (de 10 minutos no máximo), criados pelo fotógrafo e cineasta Jean Manzon, que era também colaborador do Departamento de Imprensa e Propaganda (DIP) durante a ditadura Vargas. O Ipes também foi o responsável pela criação de um banco de informações com 400 mil nomes, depois utilizado pelo general Goubery do Couto e Silva para dar início ao Serviço Nacional de Informações (SNI), órgão que começou suas atividades depois do golpe civil-militar em 1964. (PRESOT, 2010, p.78)
} 


\section{ARTE, POLÍtICA E CULTURA NOS ANOS 1950 A 1964: A BUSCA PELA IDENTIDADE BRASILEIRA}

Os anos 1950 começavam e novamente Getúlio Vargas voltava ao poder agora como presidente eleito democraticamente. Nesse momento, iniciava-se outra etapa de desenvolvimento do Brasil e também uma profunda revolução no campo das artes na cidade de São Paulo, pois o acesso à cultura começava a se ampliar.

O rádio, que era a principal fonte de informação para essa população e responsável também por oferecer diversão e cultura, não estava presente apenas nos lares das camadas mais pobres da sociedade brasileira, mas também em quase todas as casas brasileiras, isso até o final dos anos 1950.

$\mathrm{Na}$ verdade o rádio já tinha, desde os anos 1930, grande aceitação, mas foi depois do final da II Guerra Mundial que ele sofreu um processo de massificação, tornandose um fenômeno da cultura popular urbana, com uma programação calcada em novelas (radionovelas) e música, um formato difundido pela Rádio Nacional a partir de 1945.

O gosto musical mais simples, popular, se sobrepõe à vontade daqueles que imaginavam um rádio mais educativo, que levasse aos ouvintes uma cultura "superior", europeizada e da cultura nacional folclorizada. (NAPOLITANO, 2008, p.14)

Nessa mesma época, o cinema nacional também goza de grande preferência e consegue conquistar uma grande audiência com as Chanchadas (produções populares, de baixo custo), que contavam histórias simples e tinham viés carnavalesco.

\footnotetext{
Portanto, o carnaval, o rádio e o cinema, a partir da segunda metade dos anos 1940, eram os meios culturais pelos quais se consolidava uma nova audiência popular, ao mesmo tempo em que, em torno do rádio e do cinema, surgiam as primeiras formas de indústria cultural no Brasil, representando conteúdos culturais vivenciados pelas classes populares, em meio a um processo de urbanização crescente. (NAPOLITANO, 2008, p.14-15)
}

Segundo Napolitano, é nos anos 1950 que foi construída, nos meios mais populares, como no rádio, no cinema e na música, a "face coletiva do povo brasileiro", a partir de valores e práticas sociais e também de representações simbólicas, na maioria 
das vezes, ideológicas.

As características que sintetizavam essa "face cultural" do brasileiro podiam ser facilmente identificáveis na produção cultural do período, tais como a sua ingenuidade maliciosa, seu humor nato, a sua solidariedade com os menos favorecidos, a sua esperteza, ou o conformismo crítico frente às questões sociais, entre outras. Porém, esse traço "popular" que se fazia presente na política, como também na cultura, não refletia a realidade da vida social e política do Brasil, ou seja, era mais uma forma de a sociedade se representar, ou uma forma de como o Brasil "...reinventou as imagens sobre o seu povo". (NAPOLITANO, 2008, p.16-17)

O imaginário popular do povo brasileiro cordial foi utilizado pelas elites brasileiras como fator de manipulação ideológica, criando um padrão de brasileiro solícito, muito conveniente aos seus interesses. Porém, havia um conflito nessa situação, já que o povo e sua cultura eram motivos de vergonha para as elites, que se incomodavam com os conteúdos veiculados pelo rádio e pelo cinema, mostrando pessoas pobres lutando para sobreviver ou que não se enquadravam na moral da burguesia. Na tentativa de mudar esse quadro começa a ser elaborado um novo projeto de cultura para o Brasil, capaz de mostrar o lado menos popular do brasileiro e sua capacidade de se inserir na cultura europeia, considerada superior à nossa. Enquanto no Rio de Janeiro se produzia os grandes sucessos nacionais da música popular, São Paulo tinha uma produção que buscava se aproximar da do mundo desenvolvido, especialmente no teatro, no cinema e nas artes plásticas. Talvez por isso que São Paulo tenha recebido, em 1950, o que viria a ser o mais importante meio de comunicação de massa, a televisão, por iniciativa de Assis Chateaubriand.

A burguesia paulista causa grande inquietação quando decide estender sua hegemonia econômica à área cultural, concorrendo com a hegemonia cultural e política do Rio de Janeiro, que já fazia uma revolução no teatro pelas mãos de Zbigniew Ziembinski (diretor e ator polonês), Thomaz Santa Rosa (cenógrafo) e Nelson Rodrigues (dramaturgo), com sua companhia Os Comediantes. O projeto dos paulistas buscava dar uma nova identidade ao brasileiro, alinhada à modernidade e a conteúdos mais sofisticados.

Entre os anos de 1948 a 1959 são criados na cidade de São Paulo: o Museu de Arte Moderna (MAM), o Museu de Arte de São Paulo (MASP), a Bienal de Artes Plásticas, a Cinemateca Brasileira, o Teatro Brasileiro de Comédia (TBC) e a Escola de Arte Dramática (EAD), criada por Alfredo Mesquita, voltada a desenvolver a formação profissional de atores. Criado pelo industrial Franco Zampari, o TBC apresentou 
clássicos modernos, nacionais e estrangeiros, procurando "instaurar o bom gosto" teatral no público brasileiro, acostumado com as comédias mais populares apresentadas por Procópio Ferreira, entre outros artistas. (NAPOLITANO, 2008, p.19)

\subsection{O CINEMA NACIONAL}

\subsubsection{As Novas Companhias Cinematográficas}

O cinema também faz parte desse projeto. A Companhia Cinematográfica Vera Cruz (Vera Cruz) chega em 1949, com a pretensão de disputar com a produção americana, produzindo e realizando filmes com conteúdo e qualidade semelhantes aos filmes de Hollywood, se contrapondo à cinematografia carioca, mais focada nas chanchadas e comédias de carnaval, mas que devido a sua produção contínua, nos anos 1940, colaborou para o aparecimento da própria Vera Cruz.

A Vera Cruz era gerida por Franco Zampari e Francisco Matarazzo Sobrinho, o Ciccillo, vindos de famílias tradicionais da sociedade paulistana, que também estavam vinculadas à criação do MAM e do TBC.

Num circuito cultural diverso, o mundo das artes plásticas, mesmo circunscrito a um pequeno círculo social, foi fundamental para consolidar um outro fenômeno da cultura brasileira moderna, massificada nos anos 1960: a tendência formalista da vanguarda, em muitos casos próxima à abstração pura, que será vista como sinônimo de sofisticação e modernidade por amplos segmentos da elite, cujo impacto inicial se viu nas áreas de arquitetura, escultura e pintura. (NAPOLITANO, 2008, p.21)

É importante salientar que a criação da Vera Cruz tem uma profunda vinculação com o TBC, que foi um importante protagonista no movimento de renovação do teatro brasileiro. Teatro e cinema sempre tiveram, em São Paulo, uma grande vinculação; a arrancada do cinema paulista tem início nos núcleos amadores teatrais e também seu período de crise, pode ser visto no teatro. (GALVÃO, 1981, p.54)

A Vera Cruz surge então a partir da visão da burguesia paulista e da crítica local, interessada em um cinema "de qualidade técnica e artística superior" e especialmente em enredos mais elaborados, a exemplo da produção americana e 
europeia.

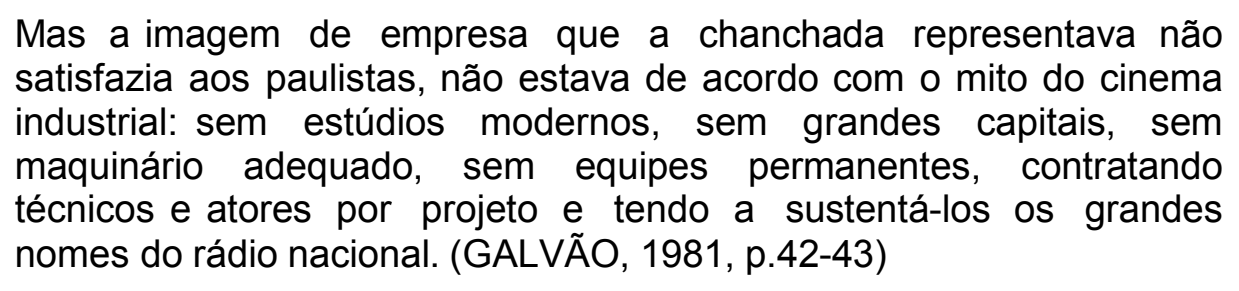

No ano seguinte, em 1950, é fundada por Mário Audrá Jr., filho de uma rica família paulistana e entusiasta do cinema, a Cia. Cinematográfica Maristela (Maristela), que via neste projeto uma forma de diversificação dos investimentos familiares, com um valor viável. Para dar corpo à empresa, a família vai buscar no TBC nomes respeitáveis das artes, como Ruggero Jacobbi e Mario Civelli e constrói um grande estúdio no bairro do Jaçanã, na zona norte de São Paulo.

\subsubsection{O Estado e a Regulamentação do Setor}

Entretanto, mesmo nesse momento promissor da atividade cinematográfica, o Estado continuava apenas a fazer concessões ao setor na forma da lei, pois acreditava que as dificuldades da produção e os diversos problemas do cinema brasileiro seriam superados sem sua interferência.

Houve uma alteração no critério de definição dos dias obrigatórios para exibição de filmes nacionais. Até 1950 as salas de cinema eram obrigadas a exibir um número fixo, que era de seis por ano. No final de 1951, a obrigatoriedade era baseada pela proporcionalidade, a conhecida "lei 8X1", ou seja, para cada oito filmes estrangeiros, um nacional deveria ser exibido.

Segundo Geraldo Santos Pereira, nesse novo critério persistiu no mesmo erro de formulação do cálculo da reserva de mercado, ou seja, "subordinando a indústria nacional a do exterior, e não o contrário, como a lógica e o patriotismo exigiriam". Ainda, segundo o autor, diversos países já adotavam, naquela época, uma estratégia de "contingenciação baseada em número de dias anuais reservados, em cada cinema, para a produção nacional, com a determinação de cotas anuais autorizadas para a importação de películas estrangeiras". (1973, p.92).

Flávio Tambellini, à época presidente da frente da Comissão Estadual de São Paulo, argumentava: 
Ligar a quantidade de filmes nacionais à de filmes estrangeiros chega a ser absurdo, se considerarmos que, por esse critério, a uma importação de 800 fitas estrangeiras deveria corresponder uma produção de 100 fitas brasileiras, enquanto para uma importação limitada, por exemplo, a 80 fitas estrangeiras (que deixaria uma enorme margem para a produção local) a exibição compulsória se limitaria a 10 fitas nacionais. (PEREIRA, 1973, p. 92)

Era um tema recorrente nos anos 1950 a busca por soluções para os problemas estruturais que de longa data se apresentavam para o cinema brasileiro: financiamento, distribuição e exibição.

A ocorrência de congressos de cinema em três momentos distintos, o I Congresso Paulista de Cinema Brasileiro e o I Congresso Nacional do Cinema Brasileiro (ambos em 1952) e, também, o II Congresso Nacional do Cinema Brasileiro (1953), espelhava bem a preocupação que os produtores e cineastas brasileiros tinham com a presença e atuação cada vez maior do cinema americano no nosso país, tanto que chegaram a promover uma série de ações e a propor um conjunto de medidas ao Estado, que fizessem frente ao cinema estrangeiro e fomentassem os filmes nacionais.

Essa movimentação foi estimulada por alguns sinais que o presidente Getúlio Vargas transmitia à classe, como o de convidar o respeitado cineasta Alberto Cavalcanti, então produtor geral da Vera Cruz, para desenvolver um estudo sobre a situação do cinema brasileiro. O resultado desse estudo foi a proposição da criação de um instituto de fomento e fiscalização para o setor cinematográfico, que viria a ser concretizada, em 1966, com a criação do Instituto Nacional de Cinema (INC).

Este estudo, na época transformado em projeto de lei, foi apresentado ao Senado, porém, acabou engavetado e esquecido nas Comissões de Comunicação e Justiça, por força da pressão feita pelos deputados e senadores para que o Instituto não ganhasse forma, que representavam, ainda que de maneira discreta, certos grupos, como o de distribuidores estrangeiros norte-americanos e de exibidores nacionais.

A criação do INC desencadeou uma disputa entre os produtores, de um lado, e os importadores e distribuidores, de outro, pois aos primeiros interessava, entre outras coisas, fazer cumprir a fiscalização da obrigatoriedade do filme nacional frente ao estrangeiro, ao mesmo tempo em que os demais questionavam a competência do INC para fiscalizar e cobrar taxas e impostos relativos às atividades cinematográficas.

Por volta de 1953 era claro o esgotamento financeiro das três empresas produtoras 
paulistas, Vera Cruz, Multifilmes ${ }^{21}$ e Maristela, todas com alto endividamento, devido aos resultados obtidos com os filmes produzidos que não deram o retorno de bilheteria desejado, além das constantes dificuldades de distribuição dos mesmos. Veremos então que essa segunda tentativa de industrialização do cinema nacional, com a Vera Cruz, redundou em fracasso por propor uma estrutura de produção própria, mas sem conhecimento suficiente em termos de custo e investimento e das Reais condições do potencial do mercado para o filme brasileiro. A Vera Cruz possuía uma extensa e cara folha de pagamento, que incluía artistas e técnicos contratados de maneira fixa e produzia, como as demais empresas produtoras, nunca se baseando no rendimento do próprio mercado.

Ainda podemos considerar que o fracasso de Zampari frente à Vera Cruz se deu em razão de sua decisão de constituir uma empresa no modelo de um grande estúdio hollywoodiano, mas sem realizar uma avaliação sobre qual era a realidade do filme nacional e sem que tivesse o controle integral de todo o processo da atividade cinematográfica, que ia muito além da produção, passando também pela distribuição e exibição, estas duas últimas atividades direcionadas, na sua quase totalidade, para os filmes norte-americanos.

Assim como aconteceu com a Multifilmes em 1954, a Maristela já começava a declinar sua produção em 1952 e, a exemplo da Vera Cruz, os problemas se repetiam numa conjunção de diversos fatores: a desigualdade econômica para competir com as grandes indústrias cinematográficas do mundo que tinham controle sobre a distribuição, preço do ingresso sem alteração, congelado pelo governo desde 1939, o que comprometia a arrecadação, face à existência de muitos filmes estrangeiros que já vinham pagos de seus mercados de origem.

Enfim, a Maristela, totalmente endividada, foi vendida para a Kino Filmes, liderada pelo cineasta Alberto Cavalcanti, que já havia deixado a Vera Cruz. Segundo Simis, mesmo "...produzindo filmes com baixos orçamentos, não se tornaram uma alternativa à produção considerada cara e complexa da Vera Cruz". (1996, p.175176) $O$ fato é que, ao final de quatro anos, Vera Cruz, Maristela e Multifilmes haviam falido e os problemas do cinema brasileiro permaneciam.

Importante destacar que na esteira das falências das empresas acima citadas e como consequência dos debates acontecidos no II Congresso Nacional de Cinema, em 1955, foi criada na gestão do prefeito da cidade de São Paulo, Juvenal Lino de

21 Criada por Mario Civelli em 1952, a Multifilmes S/A foi a responsável por produzir nosso primeiro filme colorido,Destino em Apuros (1953) e nosso primeiro filme tendo o futebol como tema central, O Craque (1953). 
Mattos, a Comissão Municipal de Cinema (CMC), que apresentou o relatório "Situação Econômica e Financeira do Cinema Nacional", desenvolvido por Jacques Deheinzelin, indicando que o Brasil, apesar de ser o líder do mercado sul-americano e o décimo no mundo em termos de espectadores, apresentava uma situação contraditória, pois havia produzido 34 filmes em 1953, enquanto que o México, com apenas 120 milhões de ingressos, havia produzido 122 filmes e a Argentina, 55 filmes, com 17 milhões de espectadores. $O$ estudo mostrava também que a despeito dos bons resultados obtidos pela Vera Cruz com seus treze filmes em comparação às demais empresas, ao final de quatro anos de exibição só conseguiu cobrir $70 \%$ dos seus custos. O relatório concluía que o principal motivo da crise cinematográfica no país se devia ao preço dos ingressos, o mais barato praticado no mundo. (SIMIS, 1996, p.180-185)

Esse cenário faz com que o Estado procure desenvolver políticas mais efetivas de apoio ao cinema nacional, como a Lei n. 4854, de 30/12/1955, instituída pela Prefeitura da cidade de São Paulo, a Lei do Adicional de Renda, que premiava os filmes que atingissem determinado patamar de renda, além de oferecer prêmios em dinheiro a técnicos e artistas escolhidos por um júri municipal de cinema.

A eleição de JK (1956-1961) acontece em meio a um clima político conturbado, com boatos de que o mesmo não tomaria posse. Vencida a crise, JK coloca em prática seu projeto desenvolvimentista, marcado pelo lema "Cinquenta anos em cinco", voltado a transformar o Brasil em um modelo de industrialização com a instalação das indústrias de base, capaz de atrair capital externo.

Juscelino enfrenta um dilema, pois tem que se equilibrar politicamente atraindo, de um lado, capitais internacionais e, de outro, buscando desenvolver o país que estava bastante limitado tecnologicamente. Fazer concessões pontuais com a incipiente indústria nacional existente antes desse processo de industrialização era uma das suas preocupações, bem como evitar situações de atrito entre setores concorrentes, dentre eles, o cinematográfico.

JK, com sua habilidade política, estava fazendo uma transformação do Brasil, tanto no aspecto social, como no econômico, e como político sagaz, sabia que tinha fazer algumas concessões para os produtores nacionais, mas sem confrontar, de maneira agressiva, os interesses de Hollywood, já que diversas indústrias norte-americanas haviam se instalado no país, como a General Motors e a Ford, ambas do setor automobilístico. Ele sabia que atritos comerciais e diplomáticos gerariam grandes desgastes, capazes de comprometer a imagem no Brasil no exterior. 
Nesse período também se delineiam medidas consideradas como o embrião de propostas que darão um novo rumo às atividades cinematográficas no Brasil. Diferente dos anos anteriores, que não apresentaram propostas mais abrangentes para o cinema nacional, a partir da segunda metade da década de 1950 acontece um movimento que passa a discutir ideias e propostas que irão influenciar o modo de relação entre o cinema nacional e o Estado brasileiro, que levará em conta a necessidade de se incluir o setor cinematográfico nos planos econômicos e sociais do país.

\begin{abstract}
Apesar de reduzida e relativa significação do cinema brasileiro, em termos econômicos, eram frequentes os paralelos com a questão do petróleo, almejando assim para o campo um estatuto que o tornasse parte integrante dos problemas nacionais em termos industriais. Interpenetravam-se,desta forma, as questões de política cinematográfica com a situação mais abrangente do país, e particularmente na visão de um cineasta posteriormente fundamental, Nelson Pereira, surgia um esboço de concepção de cultura brasileira, a qual se centrava na procura de "histórias de conteúdo nacional", de assuntos ligados à "nossa terra". (RAMOS, 1983, p.17)
\end{abstract}

A partir desse movimento, surge em São Paulo um núcleo que irá desenvolver análises sobre a situação cinematográfica e que dará início para uma aproximação entre cinema e Estado. $O$ trabalho do grupo dava mais embasamento para as discussões sobre a área cinematográfica, uma iniciativa importante na medida em que a economia do Brasil e o próprio estado brasileiro ganhavam complexidade.

Em 1955, é criada a CMC, em São Paulo, que traça um perfil do setor e aponta para o seu potencial no mercado interno. Um relatório produzido pelo cinegrafista Jacques Deheinzelin indica que "em 1953 foram vendidos 250 milhões de ingressos para uma população de 52 milhões de pessoas e uma produção de 34 filmes brasileiros" e que projetando esse valor, Deheinzelin projetava "430 milhões de espectadores para o ano de 1960" (RAMOS, 1983, p.18).

Mesmo carregado de otimismo, o relatório foi um importante documento para mostrar a vocação comercial do cinema brasileiro e também para embasar os pedidos de aumento do preço dos ingressos, da limitação da importação e de ajuda governamental para a área. A análise feita do cinema brasileiro e paulista conclui que "cinema é problema de governo", mas a prática demonstra que isso só se concretizaria se a sociedade e seu governo entendessem sua importância.

Os estudos desenvolvidos levaram propostas que conseguiram mudar o sistema da "Lei de Remessa de Rendas" dos filmes estrangeiros, extinguindo a subvenção 
câmbio para até 70\% das remessas. Em 1958, termina essa subvenção e é adotado o sistema que previa prêmios percentuais sobre a renda no município de São Paulo e financiamento feito através do Banco do Estado.

É bom lembrar que eram tempos de uma visão desenvolvimentista, portanto, o cinema deveria ser produto da iniciativa privada e ao Estado caberia criar condições para seu crescimento. Porém, quando a diretriz do governo JK de vincular seu desenvolvimento ao capital internacional chega ao cinema nacional, os sonhos de desenvolvimento da área vêm por terra, pois ao capital internacional não interessava investir na produção nacional, pois já dominava o mercado.

\subsubsection{O Grupo de Estudos da Indústria Cinematográfica}

A Comissão Federal de Cinema, criada em 1956, torna-se, em 1958, o Grupo de Estudos da Indústria Cinematográfica (GEIC), subordinado ao Ministério da Educação, aparece no momento de grande internacionalização e dependência da economia brasileira, e é mais um órgão, entre outros incumbidos de levar adiante o Plano de Metas, com a diferença que os demais estavam comprometidos com a indústria e a acumulação de capital, e o cinema, mesmo sendo concebido como uma indústria, não estava nas prioridades governamentais. Mesmo assim, o GEIC começa a incomodar os interesses do cinema estrangeiro, já que os estudos desenvolvidos, mesmo que não tivessem uma atenção especial por parte do governo, poderiam inspirar a instituição de medidas que limitassem a importação de filmes norteamericanos.

Procurando proteger numa certa medida a indústria nacional, no caso do cinema, o governo passa a taxar os filmes impressos com alíquotas de $2 \%$ a $25 \%$ e mudar o regime cambial através da Lei n. 3.244 de 1957, que estabelecia a cobrança de imposto de importação daquela mercadoria estrangeira que entrasse em território nacional e que também determinava que a remessa de lucros fosse enviada, obrigatoriamente, com base no cambio oficial. É importante ressaltar que esta lei sofreu muita pressão contrária à sua promulgação, vinda dos representantes das empresas norte-americanas, pois a eles só interessava o câmbio fixo, até conseguirem que fosse feita uma emenda alterando esse aspecto.

O cinema brasileiro recebeu pouca ou quase nenhuma ajuda do Estado, o apoio 
ficou apenas na promessa e no discurso que inseria o cinema numa perspectiva desenvolvimentista da indústria nacional, mesmo porque o GEIC estava ligado ao Ministério da Educação e Cultura (MEC), vinculado à área educacional, mais interessante ao projeto desenvolvimentista do governo. O MEC não possuía nenhuma política para o cinema, mesmo porque o próprio Estado não queria se ocupar de uma atividade que poderia causar uma situação de confronto com os interesses estrangeiros. $O$ vínculo existente do cinema com o aspecto cultural se dava pelo Instituto Nacional do Cinema Educativo (INCE), voltado ao campo do documentário educativo.

O GEIC deixou muitas das reivindicações do setor sem solução, algumas que vinham desde os anos 1950, e poucas conquistas, entre elas a exigência da cobertura cambial para a importação de filmes impressos que, somada à lei de remessa, diminuía as benesses para o cinema americano e a mudança nas regras da proporcionalidade "que garantia mercado para a produção brasileira na relação de oito filmes estrangeiros para um nacional", que passa a definir uma "cota fixa de 42 dias anuais reservados obrigatoriamente para o cinema brasileiro". (RAMOS, 1983, p.26)

Jânio Quadros assume e com ele o grupo paulista vê novas perspectivas de trabalho. A CMC convoca então a Primeira Convenção Nacional da Crítica Cinematográfica (I Convenção), que novamente levanta a questão da necessidade de proteção estatal para o setor cinematográfico brasileiro.

Nesta I Convenção se configura um avanço, com a explicitação mais clara da tendência industrialista-universalista no sentido de preservar os interesses estrangeiros, e inclusive caminha-se para propostas mais concretas de associação com o capital estrangeiro. Aprofundavase assim a divergência entre uma proposta de industrialização que reconhecia e aceitava a penetração do capital internacional no campo cinematográfico e a postura nacionalista que se colocava a favor de medidas que legislassem de forma favorável a uma industrialização cinematográfica, mas que marcava uma posição contrária aos "trustes e monopólios" que já dominavam o mercado... (RAMOS, 1983, p.28)

\subsubsection{O Grupo Executivo da Indústria Cinematográfica}

Em 1961 Jânio Quadros institui o Grupo Executivo da Indústria Cinematográfica (Geicine), mais uma tentativa de levar o cinema para mais próximo do aparelho 
estatal. O Geicine daria continuidade à linha industrialista e na visão desenvolvimentista do governo Kubitschek pretendia superar as limitações de ação do GEIC e da Comissão federal, que atuaram mais no aspecto consultivo.

O Geicine pretendia vincular o cinema a diversas áreas do governo, tanto a educacional, como as ligadas ao crédito e ao comércio exterior, buscando colocar o setor cinematográfico na pauta das questões econômicas do Estado, acabando por ficar vinculado ao Ministério da Indústria e Comércio (MIC). Suas primeiras conquistas, como a elevação da obrigatoriedade de exibição do filme nacional de 42 dias para 56 dias e de criar uma definição para "filme brasileiro", ele obtém o apoio de diversos grupos que lutavam em prol do cinema nacional, mas que, no entanto, não concordavam com suas propostas industrialistas.

A maior crítica ao trabalho do Geicine vinha da gestão que ele fazia tentando conseguir uma aproximação entre o setor exibidor e distribuidor, dominado pelo capital estrangeiro, pois na visão de seu presidente, Flávio Tambellini, nenhum cinema poderia sobreviver se não houvesse esse trabalho conjunto entre aqueles que produzem e aqueles responsáveis pela exibição e distribuição. Dentre as ações voltadas a atingir esse objetivo, uma delas, a "Lei de Remessa de Lucros" de 1962, um Decreto-lei que definia que uma porcentagem de $40 \%$ do "desconto de imposto de renda sobre remessa para o exterior dos rendimentos de filmes estrangeiros poderia ser aplicada na produção de filmes nacionais", porém, por não ser obrigatória, as empresas distribuidoras não direcionaram totalmente o desconto para a produção nacional, preferindo "recolher a totalidade dos descontos". (RAMOS, 1983, p.30) O trabalho do Geicine, de demonstrar através de amplos estudos como o mecanismo cambial favorecia a importação do produto estrangeiro, levou o governo a apresentar propostas voltadas a minimizar o problema, tais como taxar filmes impressos em alíquotas maiores, que resultou na mudança do regime de concessão de licenças de importação de filmes, aumentar a porcentagem incidente sobre depósito obrigatório, incentivar a elaboração de normas para financiamento de filmes e isentar de cobrança de impostos na compra de materiais importados utilizados por estúdios e laboratórios.

O Geicine ainda fixa, por meio do Decreto-lei n. 47.466, de 22/12/1959, em 42 dias por ano o número obrigatório de dias para exibição do filme nacional nas salas de cinema, por quadrimestre, quatorze dias, dois sábados e dois domingos, obrigatoriedade antes definida pela Lei 8x1.

É também mérito do Geicine o desenvolvimento de uma política, que depois passou 
a ser uma das preocupações do Estado brasileiro, que se refere à cota de tela, que introduziu alterações quanto à obrigatoriedade de exibição do filme nacional. Ao longo do tempo, o número obrigatório de dias para exibição do filme nacional foi sendo ampliado, chegando em 1963 a 56 dias/ano de exibição. Esse número foi alterado em 1967, com a criação do INC, pelo Decreto-lei n. 43/67, que define que o número de dias por ano passa a ser fixado pelo Conselho Deliberativo do órgão, que deve verificar a produção nacional e a possibilidade de programação do mercado exibidor.

\subsubsection{A Comissão de Auxílio à Indústria Cinematográfica}

No período anterior ao Golpe de 1964, o cinema nacional já começava a ser visto como um produto do governo e não apenas como um problema de governo. O Geicine, por sua vez não consegue superar os problemas que a falta de estrutura do setor cinematográfico trazia e só avança no sentido de conseguir uma legislação mínima para a área, mas foi a inspiração para a criação da Comissão de Auxílio à Indústria Cinematográfica (CAIC), um novo órgão do estado da Guanabara (hoje Rio de Janeiro), que aparece em 1963, no governo de Carlos Lacerda, e que retoma algumas propostas já colocadas em prática em São Paulo.

A CAIC vai injetar recursos no setor cinematográfico através do oferecimento de prêmios e financiamento, mas não apenas, também ensaiava uma tentativa de controle ideológico na produção, até então não visto em outros órgãos e comissões.

\footnotetext{
Deixava-se claro que os filmes deveriam se colocar dentro de alguns limites, adotando-se balizas ideológicas bem claras, que dariam direito a rejeitar filmes que incluíssem "propaganda de guerra, de processos violentos para subverter a ordem política e social, de preconceitos de raça ou de classe", ou ainda que tratassem de "propaganda de partido político ou associação cujo programa contrarie o regime democrático baseado na pluralidade dos partidos e na garantia dos direitos fundamentais do homem". (RAMOS, 1983, p.32)
}

Esse controle da produção procura manter o cinema longe das lutas ideológicas que o país via crescer, mas os critérios talvez não tenham sido muito rígidos, pois foram aprovados filmes produzidos pela União Nacional dos Estudantes (UNE), o Cinco Vezes Favela de 1962. 
O que podemos depreender é que nenhuma das iniciativas (GEIC, Geicine e CAIC) não conseguiu obter 0 apoio necessário do Estado para organizar 0 setor cinematográfico. As conquistas foram sempre difíceis e demoradas e os investimentos dependiam da boa vontade dos governos estaduais, apesar de o Estado sempre parecer comprometido com o desenvolvimento do cinema nacional e de se colocar a responsabilidade no cinema estrangeiro pela debilidade da produção nacional.

\subsubsection{O Instituto Nacional de Cinema (INC)}

O Instituto Nacional de Cinema (INC), uma autarquia federal diretamente vinculada ao MEC, criada em 1966, foi resultado de projeto elaborado pelo Geicine que interrompia as lutas políticas por uma política cinematográfica, colocando-as no âmbito do governo federal.

Desde sua concepção, isso na fase do projeto, já se tinha claro quais seriam as atribuições desse novo órgão e seu campo de atuação. Assim, o INC "nasce" com a incumbência de ser um órgão centralizador do desenvolvimento cinematográfico, de elaborar normas e disponibilizar recursos e de adotar uma "política liberal" para a importação de filmes, justificado como uma forma de o público "amar e conhecer o cinema em toda sua universalidade". Fato é que se procurava consolidar a ideia de que a economia do cinema, para ser eficaz, deveria ser multinacional. (RAMOS, 1983, p.51)

Responsáveis pelo INC buscavam esclarecer que o órgão não teria uma ação intervencionista, não operaria em nenhum espectro político, ou seja, teria uma ação operacional e técnica, voltada para o planejamento e a regulamentação.

$\mathrm{O}$ INC, por ter sido criado em plena vigência do Al-2 e ser dirigido por pessoas que não concordavam com as propostas do Cinema Novo (discutido em item específico neste trabalho), foi alvo de críticas. Nelson Pereira dos Santos era um que não fazia parte do grupo que apoiava incondicionalmente o INC, criticando o projeto e chamando-o de "autarquia fascistoide", que tornaria o cinema menos livre e leve, menos fluente e realista, ao ser cooptado pela subvenção oferecida por burocratas. Logicamente que as críticas de Nelson Pereira não eram isoladas. Glauber Rocha e Luiz Carlos Barreto também fizeram coro aos protestos, alertando sobre a não 
participação de cineastas na elaboração do projeto e os perigos da interferência estatal e da entrada do capital estrangeiro na produção nacional. (RAMOS, 1983, p.52)

A polêmica em torno da criação do INC não vinha apenas dos cineastas, mas também dos exibidores que temiam que a ingerência do Estado na área cinematográfica fosse uma ameaça à iniciativa privada. Assim, críticas e apoios serviram para desestabilizar grupos e misturar posicionamentos políticos, aumentando a luta cultural.

O INC, como não poderia deixar de ser, estava alinhado aos princípios mais gerais do governo ditatorial que havia dois anos tomado o poder. Flavio Tambellini à frente do órgão, ligado ao ministro Roberto Campos, cumpria o papel esperado, ou seja, de seguir as regras do regime. O Instituto dava continuidade à política desenvolvimentista pensada para o setor cinematográfico, que via o cinema nacional como:

[...] um cinema de dimensões industriais, associação em coproduções com empresas estrangeiras, e medidas modestamente disciplinadoras da penetração do filme estrangeiro (instituía-se uma contribuição para o desenvolvimento da indústria cinematográfica, calculada sobre a metragem dos filmes impressos que entrassem no país). (RAMOS, 1983, p.53)

O que se pode perceber é que o projeto do INC não confronta e não restringe a presença do cinema estrangeiro no país, mas prioriza a questão cultural brasileira, que nos anos anteriores recebera uma tímida atenção dos governos. Portanto, diferente do que havia sido visto até então, o governo Castelo Branco vai mudar a relação entre Estado e cultura, juntando o domínio obtido pela força, com a busca pela hegemonia. No mesmo novembro de 1966 é criado o Conselho Federal de Cultura (CFC). A área cinematográfica, como não existia ainda um claro direcionamento cultural para ela, continuava a se sujeitar às pressões do mercado, sob o controle e comando do governo.

Ramos considera que o que ele chama de a "esquerda cinematográfica", mesmo não concordando com o grupo que dirigia a estatal, viam o Estado como um dos responsáveis pelo desenvolvimento do cinema nacional (o próprio movimento do Cinema Novo havia recebido recursos da CAIC) e por sua afirmação cultural nacional. O mesmo Estado que rechaçava qualquer forma de nacionalismo que estivesse ligada ao governo anterior e não via com bons olhos produções que se aprofundassem na discussão dos problemas brasileiros. 
Apesar de ser um governo golpista e com forte inclinação intervencionista na área cultural, os cineastas ainda tinham esperança de que esse governo fosse neutro, isto é, técnico. Os nacionalistas idealizavam um cinema independente, construído pelo Estado e pela burguesia nacional, sonho que acabou com o Golpe de 1964, ao se constatar que o Estado não encamparia um projeto nacionalista para o cinema. Daí se pensar que então o Estado se colocaria no papel de neutralidade no âmbito da cultura, adotando medidas mais desenvolvimentistas para o cinema nacional.

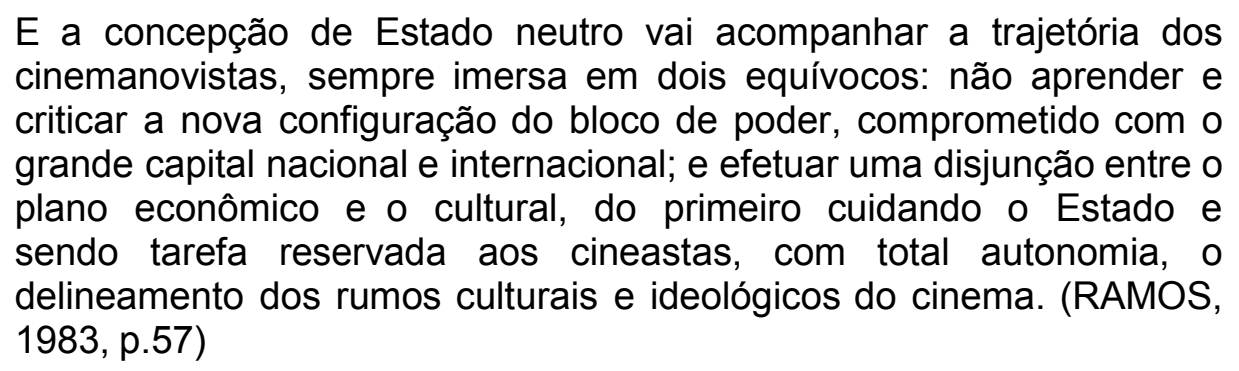

O Cinema Novo almejava alcançar uma produção independente, que segundo Glauber Rocha, com características industriais de baixo custo, com uma proposta mais cultural do que comercial (o chamado "cinema de autor"), que fosse capaz de enfrentar a poder estrangeiro no cinema nacional. Glauber entendia que sendo o cinema parte de uma indústria cultural, ele deveria ser protegido pela estrutura estatal e receber dela o justo incentivo e a liberdade necessária para sua existência.

\subsection{O PCB E A MILITÂNCIA ARTÍSTICA E INTELECTUAL}

Com a chegada do Estado Novo acontece uma transformação nas relações de poder entre os estados e o governo central. $O$ fraco federalismo da Primeira República fica para trás e a União então se prepara para elaborar, articular e dirigir o país, com um federalismo mais vinculado à economia e às finanças dos Estados, buscando fortalecer a imagem do mercado nacional. (CARONE, 1977, p.161)

A partir de 1937 a burguesia paulista perde sua autonomia política e aos poucos seu protagonismo nas questões relacionadas ao desenvolvimento econômico do país, o que dá lugar ao fortalecimento do Estado para atuar nas questões econômicas e se tornar liderança no movimento em prol do desenvolvimento do Brasil. 


\begin{abstract}
Paralelamente, a industrialização no setor privado toma uma direção inteiramente nova, com a afluência maciça de capitais estrangeiros. Os industriais paulistas esbravejam um pouco, mas se adaptam a tais modificações. A burguesia se acomoda, satisfeita consigo própria, amorfa, próspera e passiva. (GALVÃO, 1981, p.19)
\end{abstract}

Com Vargas aparecem as primeiras indústrias de base e também uma nova legislação social, reforma eleitoral, criação da Vale do Rio Doce, Siderúrgica de Volta Redonda, Ministério do Trabalho e da Educação e o Departamento de Administração do Serviço Público (DASP), responsável por importantes mudanças na administração pública.

O mundo também passa por transformações. O fim da I Guerra Mundial trouxe a ampliação e a modernização dos meios de comunicação (rádio, cinema, imprensa), que se configuraram como poderosos instrumentos de mobilização social. É um período de mudança e modernização nas estruturas de governos.

Finalmente, esse novo mundo então nascente - marcado pelo
processo urbano, industrial e tecnológico - era, por isso mesmo, o
mundo de uma sociedade de massas, vale dizer, habitado por uma
população que crescia e se concentrava, fugindo ao controle dos
governos, sendo esse fato um fenômeno tão moderno e inevitável
quanto ameaçador sem seus desdobramentos políticos. (GOMES,
2003, p.113)

Depois de 1935 começam as perseguições ao PCB, que praticamente deixa de existir. Prisões de militantes e membros do partido acontecem entre os anos de 1940 e 1942, incluindo Luiz Carlos Prestes, secretário geral do partido. Sobrevivendo à repressão, grupos estaduais, que não tinham comunicação entre si, e outros militantes, que residiam fora do país, colocam fim ao seu exílio e que quando acontece em 1941 a invasão da Rússia, se engajam nas manifestações de apoio à entrada do Brasil na guerra, ao lado dos aliados.

De 1942 em diante o PCB amplia seu campo de ação, comandando ou participando do movimento estudantil, lutando a favor da entrada do Brasil na guerra, contra o fascismo externo e a violência nazista. O próprio crescimento do PCB mostrava a importância do movimento comunista e seu protagonismo contra a política ditatorial do Estado Novo.

Em 1945, o Brasil retoma sua vida democrática. O PCB volta a agir com liberdade,vai aos poucos se estruturando, definindo seu Programa, e nomeia uma Comissão Central. A queda de Getúlio Vargas faz com que o PCB reafirme sua ideia de união nacional, uma luta da sociedade brasileira em defesa da ampliação da democracia 
e em prol do progresso da nação.

O PCB continuava a considerar - na tradição analítica que vinha do Congresso da Internacional Comunista de 1928 e sempre se mantivera no partido - que a sociedade brasileira tinha fortes resquícios feudais no campo e que, portanto, a revolução estaria na etapa democráticoburguesa. Ela não seria ainda socialista, mas sim anti-imperialista e antifeudal, nacional e democrática. (RIDENTI, 2010, p.60)

Depois do final do Estado Novo, os comunistas conseguem eleger uma bancada significativa para a Assembleia Constituinte de 1946. Essa conquista desencadeia uma reação contra o partido, com o objetivo de desarticular seus centros de ação. $O$ governo Dutra, que se dizia liberal, já indicava a necessidade de se tomar atitudes contra o comunismo. Em 1947 o Ministro do Trabalho impede que um movimento de trabalhadores seja registrado como sociedade civil e passa a excluir comunistas de sindicatos. No mesmo ano, às vésperas das eleições, o comício do PCB é violentamente dissolvido, seu estatuto é considerado ilegal pela polícia, que alegava existir divergências entre o texto que fora registrado e o apresentado à Justiça Eleitoral. É o início da cassação do PCB.

Em maio de 1947, início da Guerra Fria, o PCB é oficialmente fechado, parlamentares comunistas são cassados e o governo Dutra passa a ser considerado pelo PCB como traidor nacional e servil ao governo norte-americano, portanto, devendo ser derrubado pelo partido.

De 1948 a 1958 o PCB adota uma estratégia de recuo, buscando novas articulações e novas formas de propaganda, mas continua agindo, mesmo que de maneira ilegal e clandestina e com a ameaça de prisão de seus militantes. Em 1956, um documento assinado por Prestes indica os rumos a serem tomados pelo partido, orientação que vai vigorar até 1964.

No V Congresso, realizado em 1960, reafirma a linha que o PCB vinha seguindo:

[...] a etapa atual da revolução em nosso país [é] anti-imperialista e antifeudal, nacional e democrática. Se isto significa que a luta pelo socialismo ainda não pode ser direta e imediata no Brasil, igualmente indica que as atuais tarefas nacionais e democráticas não nos afetarão, mas, ao contrário, nos aproximarão das tarefas socialistas. (CARONE, 1985, p.365-366)

Em 1961, a vontade de colocar o partido na legalidade junto ao Tribunal Superior Eleitoral, dá início a uma campanha para conseguir 50.000 assinaturas e por decisão do V Congresso é feita a mudança no estatuto e no Programa e do nome do partido, que passa a se chamar Partido Comunista Brasileiro. A luta do PCB pela sua 
legalização continua nos anos anteriores ao Golpe de 1964.

A legalidade dá forças ao PCB e sua extraordinária expansão é tão inesperada que a estrutura organizatória vai se fazendo como decorrência do processo de crescimento. Assim, programa e formas organizatórias se vão desenvolvendo, sofrendo nuances diferenciatórias que se concretizam em formas definitivas. (CARONE, 1977, p.246)

O partido, apesar das dificuldades enfrentadas, das perseguições, ainda detém uma posição importante no cenário artístico e no meio intelectual. Para artistas e intelectuais da década de 1950, o PCB era uma possibilidade para se discutir a situação de subdesenvolvimento que vivia o país, com a maior parte da população vivendo em condições precárias, miseráveis, sobretudo aquelas pessoas da zona rural.

Entre 1947 e 1955, o PCB passa a seguir uma "doutrina estética e uma política cultural", conhecida por realismo socialista, nascida na União Soviética no final dos anos 1930 e que foi a base da produção cultural do PCB até 1953. Seriam as diretrizes principais da doutrina:

A arte deveria ser feita a partir de uma linguagem simples e direta, quase naturalista; o conteúdo deveria ser portador de alguma mensagem exortativa e modelar para as lutas populares; os heróis e protagonistas "do bem" deveriam ser figuras simples, positivas e otimistas, dispostas à luta e ao sacrifício em nome do coletivo; os valores nacionais e populares, folclóricos, deveriam ser fundidos com ideais humanistas e cosmopolitas, herdados da arte ocidental dos séculos XVIII e XIX. (NAPOLITANO, 2008, p.24)

O realismo socialista foi um método importante da literatura soviética, acontece no momento em que há um controle do Partido Comunista das organizações culturais e preconizava que não era suficiente descrever a realidade dos trabalhadores, mas sim formular "a construção de uma narrativa épica, didática, positiva", que ajudasse - Partido a "educar e moldar as almas dos trabalhadores soviéticos na forja do dogmatismo stalinista".

Segundo o método, os preceitos para a criação da ficção literária, bem como para outras áreas de expressão eram, em linhas gerais: que um escritor deveria considerar a grande diversidade no mundo e procurar reproduzir uma informação desse mundo, numa linguagem que copiasse o real, mas sem nunca criá-lo. Sua mensagem deveria ser plenamente compreendida, de modo que o leitor pudesse acreditar nas informações sobre o mundo que o escritor pretendia representar. 
(NAPOLITANO, 2010a)

Napolitano esclarece que a definição do caráter do "herói" na literatura soviética também foi uma questão central e polêmica para o fortalecimento do realismo socialista até meados de 1956. No realismo socialista, o herói positivo passou a ser uma representação da história, uma metáfora, que transmitia uma ação positiva da "consciência progressiva" do mundo e também valores éticos já existentes e valores políticos em construção.

A categoria de "herói positivo", uma vez estabelecido como cânone
narrativo, influenciou as artes engajadas em outros países e
frequentemente causa confusão na aplicação do conceito de "realismo
socialista" na análise de obras de arte politizadas. No "realismo
socialista" a herança romântica é recuperada em sua dimensão
militante e pedagógica, reforçado pelo culto ao "herói popular
proletário". (NAPOLITANO, 2010a, p.23)

O PCB reuniu muitos artistas em torno de suas propostas. A adesão ao partido tanto trazia risco como também proteção e exigia muita disciplina e obediência dos seus seguidores. Os riscos eram vinculados às perseguições, às prisões e ao preconceito contra os comunistas, e a proteção estava vinculada à solidariedade recebida dos integrantes do partido espalhados pelo Brasil e pelo mundo todo, que suscitava um sentimento de pertencimento, de fazer parte de uma comunidade. Segundo Ridenti, "...a militância no PCB podia Ihes trazer, paradoxalmente, perseguição política, mas também legitimidade e prestígio, até mesmo no exterior". (2010, p.64, 67)

Segundo Marco Napolitano, a produção dos artistas filiados ao PCB pode ser considerada como uma "arte militante", pois seguia as diretrizes do Partido, ou seja, era uma arte que tinha início na política para então atuar no que o autor chama da tríade "agitação-propaganda-protesto", era uma arte "dirigida pelos partidos e grupos politicamente organizados", diferente da arte engajada, uma arte que parte do artista envolvido em uma grande causa coletiva, guiado por um "imperativo moral e ético", ou uma atitude "voluntária e refletida" sobre o mundo, que acaba desembocando na política, mas não partindo dela. $(2011$, p.5)

A grande tarefa cultural do socialismo era menos a de inventar uma "nova cultura" proletária ou moderna, e mais a de socializar a cultura burguesa, privilégio de poucos nas sociedades capitalistas. Portanto, cabia ao artista militante ajudar a conscientizar e a mobilizar o proletariado e sua vanguarda, através de um conteúdo facilmente assimilável dentro das regras do realismo. (NAPOLITANO, 2010a, p.7) 
Literatura e dramaturgia receberam uma forte influência do PCB, assim como outras áreas da cultura. $\mathrm{Na}$ literatura, grandes autores estavam ligados diretamente ao partido, como Graciliano Ramos, Jorge Amado, Dias Gomes, entre outros. É importante destacar que personagens ficcionais criados por estes autores também contribuíram para a formação da cultura brasileira moderna. Nas histórias publicadas viam-se heróis populares em um embate contínuo contra o autoritarismo, os conservadores e capitalistas exploradores, encarnados nas personagens dos coronéis, dos padres, entre outros.

Jorge Amado foi um dos beneficiados com sua adesão ao PCB, pois teve suas obras publicadas em outros países e a partir dos contatos internacionais do partido também ampliou sua relação com artistas estrangeiros. Da mesma forma, Jorge Amado também ajudava o partido com sua fama de escritor, tanto que acabou sendo eleito como deputado, pelo PCB, na Constituinte de 1946. No apogeu do realismo socialista, Jorge Amado dirigiu a coleção Romances do Povo, publicada pela editora do PCB e com autores estrangeiros, especialmente os soviéticos ou de países socialistas. (RIDENTI, 2010, p.67)

$\mathrm{O}$ rádio também foi foco das atividades comunistas. Uma base conhecida era na Tupi de São Paulo, com Lima Duarte e Dias Gomes como militantes. Na música, o PCB estava alinhado às propostas mais nacionalistas, ou seja, que valorizassem uma sonoridade genuinamente brasileira, de origem popular, como podia ser visto nas obras de Villa-Lobos. Estava presente também no samba e em outros tipos de música popular, como nos trabalhos de Mário Lago e Nora Ney que, embora não incluísse em seu repertório músicas engajadas, militava pelo partido.

Assim como nas demais áreas artísticas, a área musical também sofria com a perseguição, mas também prestígio e legitimidade e bons contatos no exterior.

Alguns músicos, principalmente aqueles que atuavam no rádio, viam na sua militância uma possibilidade de ampliação das oportunidades de trabalho, num momento em que o mercado cultural brasileiro passava por uma "internacionalização". Esse incremento na atividade, além dos ganhos monetários, possibilitou que esses artistas, acompanhados por outros que não eram ligados ao partido, fizessem uma longa excursão de trabalho por países socialistas. (RIDENTI, 2010, p.65)

Arquitetura e artes plásticas também tiveram um vínculo ao PCB. Nas artes plásticas, os clubes da gravura foram incentivados pelo partido, alcançando destaque em outras cidades, que não Rio e São Paulo e pintores como Di Cavalcanti e Portinari 
também militaram pelo partido. Na arquitetura, Oscar Niemeyer e Vilanova Artigas eram homens do partido.

Além da literatura e da dramaturgia, ou mesmo em consequência delas, O PCB também teve um papel importante no teatro e no cinema brasileiro. Cineastas e dramaturgos, não comprometidos com o lado comercial e alinhados com a visão da esquerda, trouxeram um novo modo de ver o povo brasileiro, agora na figura do operário, muito diferente da imagem do brasileiro do campo e da cidade que até então imperava.

Já no final da década de 1950, o alinhamento do teatro ficava evidente no artigo de Gianfrancesco Guarnieri, publicado na revista Brasiliense, intitulado "O teatro como expressão da realidade nacional". Guarnieri, que na época apresentava a peça Eles não usam Black-tie, que retratava os problemas das greves de trabalhadores e que foi um grande sucesso no Teatro de Arena (Arena) ${ }^{22}$, defendia o fortalecimento da dramaturgia nacional e a lei dos "dois por um", que previa a apresentação de um texto nacional para cada dois textos internacionais apresentados.

O texto é típico da produção comunista da época, não apenas por defender a cultura nacional, mas também pela exigência de engajamento político, cobrando dos autores mensagens politizadas e conscientizadoras, com um toque que pode ser interpretado como autoritário... (RIDENTI, 2010, p.73)

Arena foi o polo difusor de peças de autores brasileiros que abordavam problemas do cotidiano brasileiro. Atores, ex-integrantes do Teatro Paulista do Estudante, como Guarnieri, Oduvaldo Viana Filho, militantes e filhos de comunistas, faziam parte do grupo teatral. Segundo Ridenti, o teatro do final dos anos 1950 buscava a brasilidade e o fortalecimento da ligação entre arte e política, e ser um teatro participante e genuinamente brasileiro. (2010, p.74)

No início de 1960, o Arena vai de São Paulo para o Rio de Janeiro, a fim de cumprir ali uma temporada de um ano e meio, que resultou em grande sucesso e deu origem ao Centro Popular de Cultura (CPC), fruto do trabalho conjunto entre Arena, de São Paulo e estudantes cariocas. É importante que se diga que o Teatro de Arena foi o principal expoente da arte engajada no Brasil dos anos 1960.

Durante o período em que se apresentou no Rio de Janeiro, alguns participantes do Teatro de Arena aderiram ao SNT, um órgão governamental que buscava a

\footnotetext{
22 Fundado em 1950, em São Paulo, o teatro se destaca pelo seu movimento de divulgação de textos nacionais, inclusive aqueles produzidos por seus integrantes. Em 1953 o teatro cria sua companhia, que vai agregar importantes artistas comprometidos com o teatro político e social e dispostos a levar à discussão a realidade nacional.
} 
popularização do teatro. Esse grupo teatral, além de levar adiante a ideia de popularizar o teatro, vinculava-a à proposta de "alfabetização conscientizadora de adultos", do método desenvolvido por Paulo Freire ${ }^{23}$.

Esse método Paulo Freire começaria a ser aplicado após em 1964 em todo Brasil, a partir do Plano Nacional de Alfabetização do Ministério da Educação, que teve Betinho como um de seus formuladores. Betinho era o principal dirigente da Ação Popular (AP) e foi assessor do ministro Paulo de Tarso Santos, que já tinha até o dinheiro para financiar a campanha, cancelada pelo Golpe de 1964.

Ao término da bem sucedida temporada do Arena, e para manter unido o grupo que participou dos trabalhos, decidiu-se oferecer um curso de História da Filosofia e como a plateia dos espetáculos era basicamente composta por estudantes, a UNE cede um espaço para que o curso fosse realizado. Apesar de utilizar o espaço da UNE, o CPC mantinha sua autonomia de ação e os trabalhos eram mantidos com a venda dos ingressos.

Com o sucesso do CPC, organiza-se a UNE Volante, que abarcava integrantes da própria UNE e também do CPC, responsável por levar aos mais importantes centros universitários do Brasil suas propostas de participação política estudantil. É fato que o trabalho da UNE Volante só foi exitoso por conta das apresentações teatrais do CPC, acompanhadas de inflamados discursos de seus integrantes.

Esse movimento artístico comprometido com as causas sociais do Brasil e ligado à cultura comunista presente no teatro, no cinema e na literatura desse período trouxe uma renovação das estratégias políticas do PCB. Em 1958 o PCB chamava para si a responsabilidade de instaurar uma "democracia burguesa forte" e de fomentar o progresso industrial brasileiro, baseado no capital nacional. (NAPOLITANO, 2008, p.29)

Como o Arena, também o CPC e o Teatro Opinião (Opinião) estavam em sintonia com o momento político de então, diferente do TBC, uma referência do teatro nos anos 1950, tido como afastado das questões nacionais e do próprio povo, por focar sua produção na dramaturgia estrangeira.

Os artistas, dramaturgos e os intelectuais vinculados ao PCB estavam unidos em torno de uma mesma proposta, a de popularizar e valorizar a arte e a cultura brasileira, retratando o cotidiano do povo e assim se aproximando do que eram suas necessidades, empenhando-se com a educação da população e com o fim do

\footnotetext{
23 Educador pernambucano (1921-1997), criador do método de alfabetização de adultos, que vinculava a alfabetização ao cotidiano do trabalhador. Para Paulo Freire, o adulto deveria conhecer sua realidade para poder inserir-se de forma crítica e atuante na vida social e política.
} 
subdesenvolvimento, ou seja, como diz Ridenti (2010), artistas e intelectuais comunistas foram agentes fundamentais do que se pode denominar de brasilidade revolucionária, e mais:

Talvez o PCB - como esboço de "construção de uma (contra) elite de
corte nacional - tenha constituído, nos anos 1950 e início da década
de 1960 , a ala esquerda de um movimento mais abrangente que
apostava nodesenvolvimento nacional com base na intervenção do
Estado, modernizando a sociedade brasileira e tirando-a do "atraso",
rompendo com o poder dos latifundiários e ampliando
significativamente os direitos sociais. (RIDENTI, 2010, p.75)

O PCB também desenvolveu um trabalho importante na área educativa para a formação de novos quadros, isso no início dos anos 1950, tendo em vista a perda de sua força política. As aulas, que duravam de dois dias e um mês, eram dadas nas escolas clandestinas espalhadas por várias capitais brasileiras, que dependiam de uma estrutura para hospedar, alimentar esconder dezenas de militantes, que não conheciam suas localizações. Os professores eram dirigentes do partido, com boa base intelectual e política, e eram remunerados para exercer a atividade. A rotina de estudo era puxada, exigia dos alunos muita dedicação. Compunha o conteúdo das aulas orientação política, ética e comunista, e sobre a construção do socialismo. Jacob Gorender foi um dos principais professores.

Havia também um sistema de formação intensiva, ou seja, cursos clandestinos, que tinham a duração de dois a quatro dias, oferecidos principalmente para operários de todo o Brasil e cursos dirigidos aos dirigentes, realizados no Rio de Janeiro, mas que também contavam com a presença de alunos de outros países da América Latina. Alguns alunos foram enviados à URSS para cursar a Escola de Quadros, como o próprio Gorender. O que se via era uma organizada estrutura capaz de oferecer cursos de formação em todas as regiões do país e até em Moscou.

Os cursos do PCB deixaram frutos, como a mudança democratizante do partido no final da década de 1950 e o renascimento político e cultural do país, pois muitos jovens intelectuais da ainda principiante Universidade de São Paulo (USP), nos anos 1950, se aproximaram dos militantes do PCB. O fato de o partido manter viva uma gama de publicações que chegavam a todo o Brasil, fez dele também uma escola de jornalismo. O difícil acesso à universidade e as poucas oportunidades de troca de informação, faziam com que houvesse muita procura para publicação de artigos nos periódicos do PCB. "Apesar das perseguições, do pesado estigma de ser comunista e da disciplina dura do PCB, abria-se um caminho para aprimorar a formação, 
difundir ideias e obras e obter certa legitimidade intelectual." (RIDENTI, 2010, p.79)

E até a metade dos anos 1950, o PCB foi um importante canal de expressão para artistas e intelectuais que atuavam no partido, revelando e dando visibilidade às suas obras. Mais à frente, com o crescimento das universidades e o aparecimento de instituições acadêmicas financiadas pelo governo, como o ISEB, faz o PCB perder espaço e reduzir sua importância, o que o levou a aproximar-se tanto do ISEB, como das universidades.

Embora o Partido Comunista tenha feito a leitura do manifesto, não significava que todos os membros do CPC fossem comunistas, mas de alguma forma eram simpáticos à cultura nacionalista de esquerda.

O ponto comum entre eles era a defesa do nacional-popular, expressão que designava, ao mesmo tempo, uma cultura política e uma política cultural das esquerdas, cujo sentido poderia ser traduzido na busca da expressão simbólica da nacionalidade, que não deveria ser reduzida ao regional folclorizado (que representava uma parte da nação), nem com os padrões universais da cultura humanista como na cultura das elites burguesas, por exemplo. (NAPOLITANO, 2008, p.37)

No cinema o PCB também teve adeptos. No início dos anos 1950, em São Paulo, o pessoal mais jovem do cinema tinha uma certa ligação com o partido, sendo filiado ou não, como Alex Viany, cineasta e crítico de cinema. Viany, que combatia em seus textos o cinema de estúdio brasileiro, defendia um cinema não-empresarial que mostrasse a vida do povo brasileiro e alertava para o quanto a cultura americana estava presente na vida dos brasileiros.

\begin{abstract}
Em torno das ideias dos críticos de cinema do PCB surgiu um conceito de cinema brasileiro: o capital, o estúdio e o laboratório deveriam ser $100 \%$ nacionais; dois terços da equipe técnica e todos os intérpretes principais deveriam ser brasileiros. Além desses aspectos de produção, o filme brasileiro deveria desenvolver um tema nacional, buscando o homem brasileiro como homem do povo. (NAPOLITANO, 2008, p.26)
\end{abstract}

Segundo Ridenti, a carreira do cineasta Nelson Pereira dos Santos, no período de 1940 e 1950, é um exemplo para ilustrar a relação que havia entre o PCB e a área político-cultural da época. "Ele fora formado pelo partido - desde a célula estudantil no colégio Roosevelt de São Paulo, depois na Faculdade de Direito da USP - para ser um no quadro, com carreira ligada às determinações e disciplinas partidárias..." (2010, p.70).

Nelson Pereira dos Santos filma seu longa metragem Rio 40 graus (1955), 
contrariando a vontade do PCB, o que lhe custou sua transferência do comitê cultural do PCB, para uma célula do partido no bairro de Santa Teresa (RJ). Esse fato não indica que o PCB não percebesse a importância do cinema, mas demonstrava sua reprovação quanto ao fato de o cineasta ter filmado contrariando as determinações do partido. O curioso nesta história é que mesmo que a filmagem tenha sido desautorizada pelo $\mathrm{PCB}$, atores e técnicos comunistas participaram do filme e ainda aproveitaram para fazer divulgar as ideias do partido na favela, onde o filme estava sendo rodado.

O filme, que chegou a ser censurado e impedido de ser exibido por muito tempo (por ordem do chefe de polícia que considerou que mostrava um lado feio do Rio de Janeiro, podendo incitar protestos), retratava a vida do brasileiro, suas esperanças, alegrias e seus dramas e mostrava pela primeira vez, de maneira explícita, a realidade do povo brasileiro. O filme deu a Nelson Pereira o prêmio de Jovem Realizador em um festival Tcheco, em 1956, e foi utilizado na campanha a presidente de JK.

Esse episódio talvez coincida com relatos sobre casos de censura e crítica praticadas pelo partido, principalmente quanto ao afastamento do realismo socialista. Não que existisse uma censura organizada, ou seja, uma prática institucionalizada de controle. O que ocorria, segundo Ridenti, é que o partido cobrava mais "coerência e obediência dos intelectuais dependentes do PCB, notadamente os que empregava". Ainda segundo o autor, artistas mais independentes profissionalmente tiveram menos do que reclamar "do que os "revolucionários profissionais" empregados na imprensa ou na burocracia partidária". (2010, p.81)

Ridenti observa que os comunistas realizaram um importante trabalho de base nos cineclubes através do cinema, levando ao público filmes que não chegavam ao circuito comercial e também outros clássicos. Era a concepção de arte como expressão, como possibilidade de provocar emoção sem ser piegas e alienada, que também fez adeptos no teatro. No final dos anos 1950, artistas e intelectuais ganham mais liberdade para atuarem nas suas áreas, desde que respeitassem a orientação geral do PCB, fazendo assim prosperar a produção artística e intelectual dos comunistas, até que acontece o Golpe de 1964. 


\subsection{O CINEMA NOVO}

No início dos anos 1960 era clara a ausência de um projeto estatal para a cultura nacional. O cinema também não era pensado numa perspectiva político-estatal, e apesar de relegado a segundo plano e considerado uma atividade marginal, ganha repercussão com a chegada do Cinema Novo, que trazia novas propostas e, mesmo que na sua primeira fase apresentasse uma produção tímida que não Ihe dava uma "penetração ideológica", pregava a desalienação do público e a libertação nacional. (RAMOS, 1983, p.42)

A corrente nacionalista acreditava na possibilidade de o país conseguir uma independência econômica que freasse a sua crescente internacionalização, e essa discussão acaba sendo tema em diversos segmentos culturais, incluindo o cinema.

É um momento importante de erupção de visões da cultura brasileira que procuram uma aproximação politizada com a cultura popular - mesmo que de forma equivocada e oscilando do paternalismo ao tradicionalismo -, forçam a relação entre intelectuais e classes populares, caracterizando um momento fundamental de colocação da questão nacional.

O Cinema Novo nasce no final dos anos 1950 e início dos anos 1960, a partir dos filmes de curtas metragens realizados nesse período, no Rio de Janeiro como $O$ Maquinista (1958) de Marcos de Farias e Arraial do Cabo (1960) de Paulo Cesar Sarraceni; na Bahia como Um dia na rampa, documentário de Luís Paulino dos Santos e Pátio, filme experimental de Glauber Rocha; na Paraíba como Aruanda, documentário de Linduarte Noronha.

O Cinema Novo era um cinema de produção de baixo custo, independente, que mostrava os problemas do brasileiro ou segundo Napolitano, um cinema inspirado no "neo-realismo italiano e na nouvelle vague francesa, que defendia um cinema de autor, despojado, fora dos grandes estúdios e com imagens e personagens mais naturais possíveis". (2008, p.45)

A publicação de artigos de Glauber Rocha, Gustavo Dahl e Jean-Claude Bernadet em jornais de grande circulação da Bahia, São Paulo e Rio de Janeiro deram início ao processo de estruturação do movimento que durou até 1967, que então ganha repercussão. (RIDENTI, 2000, p.90) Depois, o Cinema Novo amplia sua produção para filmes de longa metragem, que faz o movimento ganhar notoriedade internacional. 
Cineastas como Glauber Rocha, Ruy Guerra e o experiente Nelson Pereira dos Santos $^{24}$ lançam uma proposta de um cinema brasileiro que mostrasse o Brasil fugindo do modelo hollywoodiano da Vera Cruz e das chanchadas da Atlântida, que os jovens cineastas comunistas chamavam de uma representação caricata do povo brasileiro.

[...] o conceito de alienação se entrecruzava com o nacionalismo, costurando o tecido que sustentava, e de alguma forma unificava, a diversidade da produção cultural da época. (RAMOS, 1983, p.75).

O Brasil vai produzir então, no período que vai de 1960 a 1964, filmes importantes. Dentre eles, podemos citar: Barravento (1960) de Glauber Rocha, que abordava a questão dos pescadores nordestinos, Vidas Secas (1963), de Nelson Pereira dos Santos, baseado no livro homônimo de Graciliano Ramos; Cinco vezes favela (1962) e Gimba (1963) de Flavio Rangel; Os fuzis (1964) de Ruy Guerra; Esse mundo é meu (1964) de Sergio Ricardo; e, Deus e o diabo na terra do sol (1964), de Glauber Rocha.

O Cinema Novo propunha a simplicidade formal da "ideia na cabeça e uma câmera na mão", como a Bossa Nova, com "um banquinho e um violão", mas diferentemente desta que cantava um Brasil moderno e urbano, os maiores sucessos do Cinema Novo abordavam o lado "rural, violento, arcaico e opressor" do país. (NAPOLITANO, 2008, p.31-32)

Num país cada vez mais dividido politicamente e que procurava saídas para os seus impasses sociais, culturais e econômicos, a arte e a cultura eram espécies de "laboratório de ideias", campo de elaboração de projetos ideológicos para o Brasil. (NAPOLITANO, 2008, p.33)

A intenção dos cineastas era mesmo tirar o público brasileiro e estrangeiro da situação de conforto, mostrando a realidade brasileira e as relações sociais conflituosas, de maneira real, longe do luxo e da beleza dos filmes de Hollywood. O movimento do Cinema Novo tinha como tema a "estética da fome", explicitada em manifesto escrito por Glauber Rocha em 1965, que fazia uma análise do cinema nacional e latinoamericano. Glauber dizia:

\footnotetext{
${ }^{24}$ Marcos Napolitano entende que os primeiros filmes do cineasta Rio, 40 graus de 1954 e Rio, Zona Norte de 1957) não estavam alinhados ao movimento do Cinema Novo, nem na questão estética e nem de público, pois os filmes trabalhavam com elementos musicais e dramáticos, representados em um meio social popular, com linguagem fílmica realista e com uma narrativa palatável a um público mais amplo. (2001, p.112)
} 
Nem o latino comunica sua verdadeira miséria ao homem civilizado nem o homem civilizado compreende verdadeiramente a miséria do latino. [Por isso somos] contra os exotismos formais que vulgarizam os problemas sociais. (NAPOLITANO, 2008, p.45-56)

E mais,

(...) o Cinema Novo, no campo internacional, nada pediu, impôs-se pela violência de suas imagens (...), pois através da violência 0 colonizador pode compreender, pelo horror, a força da cultura que ele explora. (NAPOLITANO, 2008, p.46)

O filme Cinco vezes favela foi um filme representativo do cinema que colocava seu foco e sua meta na questão da conscientização contra a alienação. O filme, já na sua produção, fugiu do sistema comercial, e sendo subsidiado pelo CPC e pela UNE teve maior liberdade para se adequar aos pressupostos políticos e artísticos do CPC. No filme, composto por cinco curtas, até a música tinha um viés ideológico, e colaborava para associar a cultura popular ao nacionalismo.

A forma de abordar o "popular", através dos pares alienação/conscientização ou cultura popular alienada/cultura popular revolucionária, conduzia as obras a um desdobramento interior de dicotomias simplistas, perdendo-se a complexidade das relações de força que penetram tanto o domínio da cultura popular como o da cultura hegemônica. (RAMOS, 1983, p.45)

O Cinema Novo não conquistava grandes públicos, mas sim as mentes de muitos intelectuais e artistas de esquerda de diversas áreas que, inspirados pelo movimento, chegaram a realizar filmes ou desejaram tornar-se cineastas. O cinema era então tido, segundo Glauber, como "a consciência nacional”, "o espelho intelectual, cultural, filosófico da nação". (RIDENTI, 2000, p.91)

[...] uma obsessão marca os cineastas que se formaram no bojo do movimento Cinema Novo, e se empenharam na luta por uma indústria cinematográfica: a perseguição constante de um enigmático "homem brasileiro", a ânsia em apreender a "realidade brasileira". Trata-se enfim da intrincada questão da identidade nacional que atormenta os produtores culturais, a forma política específica que assumem as preocupações com um possível "nacionalismo cultural" no campo do cinema brasileiro. (RAMOS, 1983, p.13)

Essa limitação de público se dava, justamente, por causa do conflito entre uma linguagem moderna para representar o antigo, da sua narrativa diferenciada, da característica alegórica dos personagens e, principalmente da aposta do movimento em fazer um filme que rompesse com o modelo do cinema industrial. Segundo 
Marcos Napolitano, o dilema da cultura brasileira, do final dos anos 1950 até início dos anos 1960, era conciliar a modernidade com o popular. (2008, p.35)

O Golpe de 1964 faz com que os artistas tenham que repensar seus modos de fazer arte, mas sem que fossem abandonadas as propostas de esquerda para o setor. $\mathrm{O}$ governo, por seu lado, procurava isolar o movimento cultural das camadas mais populares. A situação chega a um impasse quando, em 1968, há o recrudescimento da atuação do regime militar no país.

Ainda em 1965, Glauber escreve seu manifesto sobre a "estética da fome", que guia a primeira fase do movimento cinemanovista, no qual o cineasta apontava a situação do cinema nacional e latinoamericano. Glauber via uma relação direta entre a crise do cinema e a fome que assolava o país e, sendo assim, o filme não deveria ser arte, mas antes um manifesto.

Os cineastas ligados ao Cinema Novo também buscaram adaptar sua produção aos novos tempos do regime. Glauber Rocha ganha, em 1969, o prêmio de melhor diretor, em Cannes, com o filme O Dragão da maldade contra o santo guerreiro; Nelson Pereira dos Santos faz o importante Como era gostoso meu francês (1971), uma crítica ao estrangeirismo e alusões sutis à tortura, censura e à guerrilha; e, Joaquim Pedro de Andrade, com seu Macunaíma (1969), faz uma releitura do antiherói de Mário de Andrade.

Glauber foi o artista do Cinema Novo que mais se aproximou ideologicamente da luta armada, muito provavelmente em razão de sua convivência com guerrilheiros brasileiros quando de sua estadia em Cuba, e era tido por alguns como ligado à ALN. Mas Glauber fez em diversas ocasiões duras críticas à esquerda armada, por entender que a guerrilha não era capaz de chegar às camadas mais remotas e profundas do povo brasileiro, por ser o Brasil um país formado por um conjunto de etnias, culturas e realidades econômicas desordenado e dividido ${ }^{25}$.

Assim era Glauber, questionável e paradoxal e, segundo Marcelo Ridenti, um representante do nacionalismo terceiro-mundista, romântico e moderno, da esquerda dos anos 1960, e que tinha uma proposta de construir um novo povo brasileiro e nação brasileira, que apresentava de maneira criativa e sempre antiliberais. Para Glauber:

[...] não somente a esquerda, mas os partidos liberais não são mais que uma excrecência europeia num mundo desconhecido, cujas leis

25 Trecho de entrevista publicada em 1969, no Front Brésilien d'Informations, uma revista dos exilados brasileiros. (RIDENTI, 2000, p.173) 
eles não conhecem. [...] Meu país é um continente desconhecido. [...] grande drama do Brasil é que ele não se conhece a si mesmo... (Front Brésilien d'Informations, s.n.t., p.9-11 in RIDENTI, 2000, p.173)

Outro cineasta que também vai contribuir na reflexão sobre o Cinema Novo foi Cacá Diegues que temia que uma possível crise econômica, depois do Golpe de 1964, poderia interferir nos rumos do cinema brasileiro. Faz assim uma análise realista do movimento e apresenta uma proposta, que fazia uma nova leitura e dava a ele um novo rumo. Saíam a pobreza e a violência como elementos que despertavam a conscientização e a libertação, ficando em seus lugares um maior foco na cultura brasileira, para então proceder a uma "investigação antropológica do homem brasileiro". Mais tarde, em 1970, essa discussão voltará à cena e com força total, mas agora conduzida pelo Estado por meio de sua política cultural. (RAMOS, 1983, p.78)

Nesse momento de questionamento do Cinema Novo, chega às telas o filme Macunaíma (1969), de Joaquim Pedro de Andrade, que resume essa discussão e torna-se um marco do processo de reflexão e problematização do cinema nacional. O filme retoma o trabalho de Mário de Andrade, escritor que se debruçou na pesquisa da nacionalidade brasileira, se é que houvesse uma, além de estudar o lado bom caráter do homem brasileiro, em resumo, Mário de Andrade procurava criar uma "cultura brasileira".

O cineasta muda o final dado por Mário de Andrade a Macunaíma, fazendo com que ele morra ao final devorado pela lara, ao som de Villa-Lobos, pois um herói "fraco, carente de perspectiva globalizante, individualista", não tinha lugar nos "tempos modernos", que "não admitem um herói fracassado, tímido, fossento e triste". (RAMOS, 1983, p.82)

No período que vai do final dos anos 1960 até a metade dos anos 1970, o cinema brasileiro sofria com o domínio do cinema hollywoodiano e com a opção intelectualizada do Cinema Novo, de forma que passa a depender cada vez mais de dinheiro público para realizar filmes com uma proposta menos popular. É importante destacar que nesse período as discussões presentes no cinema nacional que gravitavam em torno de aspectos políticos, culturais, em função do cenário político e do rápido processo de modernização que causava uma grande pressão na vida do país.

O INC praticamente obriga que os cineastas trabalhem em conjunto com empresas estrangeiras, por força dos mecanismos de produção criados pelo órgão, que de 
certa forma tem um resultado positivo, aumentando a produção cinematográfica nacional. Glauber se colocava contrário dessa política implantada pelo INC e, depois de realizar Terra em Transe, vai buscar recursos financeiros no exterior, a fim de dar continuidade a seu projeto anticolonialista e talvez dar início a um cinema do terceiro mundo. O lançamento do seu filme $O$ dragão da maldade contra o santo guerreiro, em 1969, produzido com dinheiro das TVs alemã e francesa, trazia a esperança de conseguir sucesso de público. Depois dele vieram mais dois filmes, que inovavam no aspecto político e estético, O leão de sete cabeças, filmado em 1969 na África, e Cabeças cortadas, filmado na Espanha, em 1970.

Não havia a intenção, da parte do INC, de se contrapor aos interesses dos estrangeiros, ao contrário, o órgão estava preso a compromissos que não lhe deixavam opção senão a de se aliar a eles. Assim, só restava ao Cinema Novo se utilizar do que o INC poderia Ihe dar.

A partir de 1967, em São Paulo, na Boca do Lixo, era produzido um cinema que não estava vinculado à movimentação política e que não buscava apoio do Estado, com pretensão apenas comercial, que ficou conhecido como "Cinema Marginal" ou "cinema do lixo". O mesmo movimento chegou ao Rio de Janeiro, com Júlio Bressane e Neville D'Almeida.

\footnotetext{
Originou-se uma produção que desprezava a industrialização e dialogava culturalmente com o Cinema Novo, pregando um cinema que assumisse o seu "subdesenvolvimento", a sua pobreza, o seu "lixo". Não havia entre os "marginais" a preocupação com um desenvolvimento independente do cinema brasileiro, inexistia um projeto industrial articulado. (RAMOS, 1983, p.67)
}

Segundo Inimá Simões

O ciclo erótico não surge por geração espontânea. Ao contrário, acompanha uma onda cinematográfica internacional e se beneficia do fechamento do regime político que desestimula o tratamento de temas "sérios". (1999, p.165)

Simões avalia a importância do próprio INC nesse processo, criado "para introduzir no mercado cinematográfico brasileiro relações capitalistas modernas", colabora para que haja uma mudança, saindo a proposta cinemanovista, definida na frase "uma ideia na cabeça, uma câmera na mão", para entrar outra, "cinema é indústria" ou "filme é cultura", que parecia mais simpática. Desta forma, a produção erótica tem garantida sua presença no circuito cinematográfico brasileiro, e que coloca em destaque o produtor dos filmes, e não mais o diretor-autor, como acontecia nos anos 
1960. (SIMÕES, 1999, p.165)

Um filme que marca o início do cinema marginal foi o A margem (1967), de Ozualdo Candeias, que abordava a marginalidade de uma grande cidade. Outro filme, que conseguiu grande prestígio do movimento marginal foi o Bandido da luz vermelha (1968), dirigido por Rogério Sganzerla. É bom que se diga que as produções do cinema marginal contavam com a grande criatividade dos seus produtores, que tinham que superar a pobreza retratada nos filmes e a encontrada na produção.

Os anos 1969 e 1970 foram anos de grande produção para o cinema paulista, que tinha investidores de todas as origens, o que também dava a tônica de seus filmes. Havia a preocupação com a colocação e a quantidade de semanas que esses filmes ficavam em cartaz no mesmo cinema, que definia o preço dos filmes, mas nenhuma preocupação de conscientização do espectador ou de ser visto como um produto cultural. Na verdade

[...] os filmes se pretendiam sujos, feios, se valendo do erotismo possível e de títulos chamativos. A própria forma de produção, ao invés de circundar a burguesia nacional como o Cinema Novo, tinha suas origens em pequenos capitalistas, numa espécie de "marginalidade econômica", e assim a sustentação da proposta cultural permitia - aliás, nem deveria se interessar por este aspecto os exercícios estéticos dos cineastas. (RAMOS, 1983, p.69)

Sobre a produção do ciclo erótico, Inimá Simões ressalta:

O que define, a rigor, uma pornochanchada, não é tanto a presença de uma temática erótica, inspiradora de milhares de obras de arte ao longo da história, desde escultores gregos, passando por Ovídio e chegando à época moderna, mas sim a maneira como essa temática é tratada, ou, em outras palavras, o baixo nível cultural e técnico de certas produções. Indo além, se algo deveria ser combatido, eram os filmes de ocasião, oportunistas, feitos para atender à voracidade comercial, que no fim cometem transgressões milimetricamente calculadas. (1999, p.204-205)

\subsection{CULTURA E POLÍTICA NO PERÍODO PRÉ-1964}

Com o fim da II Guerra, o Brasil passa por um processo de industrialização e de modernização industrial. $\mathrm{O}$ aumento da classe operária paulista é significativo, por conta da chegada de imigrantes que fugiam da crise europeia no pós-guerra. E é essa nova classe média que contribui para a movimentação da cultura em São 
Paulo, tanto como produtora, como consumidora dessa produção cultural.

O aumento da produção tem consequências mais do que quantitativas, significa a metropolização de São Paulo - mudança de qualidade. $O$ mercado mínimo para o consumo de cultura passa a ser um mercado satisfatório. [...] E a burguesia paulista assume concreta e ideologicamente a função de propulsora das artes e da cultura. (GALVÃO, 1981, p.17)

Pode-se perceber na década de 1960 um crescimento da atividade cultural e política que estava relacionado a fatores materiais, como a ampliação da classe média, maior acesso ao ensino superior, a questão da crescente urbanização do país, aumento do número de jovens na composição da população e a assimilação por esses da cultura das metrópoles, o avanço tecnológico e o consumo de eletrodomésticos, principalmente a televisão.

Foram anos em que o Brasil vive um período de agitação, tanto na área política, como na área cultural, que buscava mudanças e a realização de um ideal de revolução, capazes de trazer novos ares à política, à cultura, aos costumes. Em paralelo, o mundo vivia sob o manto da Guerra Fria, do perigo comunista.

De 1961 a 1964, no governo Goulart cresceram, na sociedade brasileira, ações populares relacionadas à defesa de projetos políticos. O Brasil presencia operários, estudantes, pessoas do campo e outras categorias organizadas saírem às ruas em manifestações e em movimentos grevistas.

Mas o fantasma da ameaça comunista chega ao Brasil e com ele um profundo sentimento anticomunista. Começa a se delinear uma disputa entre grupos de orientação ideológica oposta e o crescimento dos movimentos sociais, em um embate no qual de um lado ficavam os que se identificavam com o conservadorismo político e que "trabalhavam" na desestruturação do governo João Goulart e do outro lado a esquerda, comprometida com propostas reformistas e que já começavam a radicalizar suas propostas.

[...] imagens valorizadas do ideário "ocidental e cristão" foram se reconstituindo e se difundindo, especialmente por meio de certos grupos ou instituições que se mostravam, em diferentes graus e segundo interesses diversos, cada vez mais preocupados com 0 "perigo comunista", que se lhes afigurava mais próximo desde a Revolução Cubana, em 1959, e a opção por um governo socialista naquele país, em 1961. (PRESOT, 2010, p.73)

Muitos desses movimentos sociais entenderam que o caminho da mudança começaria pelas Reformas de Base (Reformas), ou seja, em projetos destinados a 
promover avanços, não só na vida urbana, mas também na vida rural, e que também impulsionassem mudanças na educação, assegurassem o direito a voto para analfabetos, o controle do capital estrangeiro e a nacionalização de setores da economia. As Reformas pretendiam atacar os problemas estruturais do país e governar com base em um planejamento econômico, mas a complexidade para sua execução dificulta muito a ação governamental.

Em torno dessa proposta estavam também os partidos de esquerda e outras instituições sindicais, como o Comando Geral dos Trabalhadores (CGT), bem como as organizações estudantis e representantes de trabalhadores rurais. Esse movimento pró-reformas ganha mais força no período final do mandato João Goulart, estimulando as pressões sobre um governo fragilizado pelas crises políticas, institucionais e econômicas, herdadas das gestões anteriores.

A classe média que se sentia ameaçada pela crescente perda de seu poder de compra e assustada com a opção mais pela esquerda do presidente João Goulart, compunha esse cenário de instabilidade e de insegurança ao tentar se proteger do perigo comunista que assolaria o país, como os conservadores e os empresários tratavam de alertar. Por estarem descontentes, ansiavam por medidas que contivessem as forças populares e que promovessem o equilíbrio da economia.

Os opositores do governo Jango usaram referências simbólicas para caracterizar o "inimigo comunista", como a alusão aos símbolos católicos, relacionando o comunismo à sombra, às trevas, ao medo e ao terror, dizendo-o capaz de destruir os três pilares da sociedade livre: Deus, Pátria e Família. (PRESOT, 2010, p.75)

João Goulart ficaria enfim isolado, cercado de um lado por uma direita que via como ameaça a tendência "esquerdista" do presidente e de outro lado por uma esquerda que começava a duvidar do seu governo por perceber que suas propostas ficavam mais no nível das promessas. Em uma tentativa de reconquistar as massas, Jango promove o Comício pelas Reformas (também conhecido como o Comício da Central), que buscava disseminar a intenção do governo em implementar as reformas de base e garantir as liberdades democráticas e sindicais. O comício que aconteceu no dia 13 de março de 1964 reuniu cerca de 150 mil pessoas.

Se Goulart promovia seu compromisso com as reformas, famílias da zona sul carioca acendiam velas e mulheres paulistanas rezavam o terço para afastar o perigo comunista do país. O presidente reage a tais manifestos criticando a exploração dos sentimentos cristãos do povo e declarando: “...não podem ser levantados os rosários 
da fé contra o povo, que tem fé numa justiça social mais humana e na dignidade de suas esperanças." (PRESOT, 2010, p.76)

Essa declaração tem como resposta a "Marcha da Família com Deus pela Liberdade", um movimento de desagravo, realizado no Rio de Janeiro, ao rosário ofendido por João Goulart. A mesma declaração também foi distorcida pela associação Campanha da Mulher pela Democracia (Camde), do Rio de Janeiro, fundada em 1962, que afirmou que o presidente teria dito que "os terços e a macumba da zona sul não teriam poder sobre ele". (PRESOT, 2010, p.76). A manifestação foi patrocinada pelo Ipes e teve a participação também de militares de alta patente e representantes do clero tradicional.

Incentivadas pelo sucesso da Marcha da Família com Deus pela Liberdade, outras marchas se espalham pelo país, sendo que a maior parte delas aconteceu depois de 31 de março, dia em que a "Marcha" foi realizada. As marchas invocavam a população a abraçar valores como amor à pátria, respeito à democracia, à família e às liberdades políticas. Um material de propaganda distribuído pelas instituições que promovia o evento chamava a atenção para o viés cívico e religioso das marchas, voltadas a "...reafirmar os sentimentos do povo brasileiro, sua fidelidade aos ideais democráticos e seu propósito de prestigiar o regime, a Constituição e o Congresso, manifestando total repúdio ao comunismo ateu e antinacional". (PRESOT, 2010, p.79)

O governo de João Goulart faz crescer o movimento anticomunista e ampliar o apoio ao golpe civil-militar que se daria naquela data, em razão de sua deposição. As Marchas da Família com Deus pela Liberdade foram um indicativo de como o teor dos discursos anticomunistas, de amor à pátria, à família foram ao encontro das expectativas e dos medos da sociedade brasileira.

Houve, na década de 1960, um crescimento da atividade cultural e política que estava relacionado a fatores materiais, como a ampliação da classe média, maior acesso ao ensino superior, a questão da crescente urbanização do país, com o aumento do número de jovens na composição da população e a assimilação por esses jovens da cultura das metrópoles, o avanço tecnológico e o consumo de eletrodomésticos, principalmente a televisão.

A televisão mantém-se como novidade por ser inacessível às pessoas de mais baixa renda, ou seja, ela ainda era um produto que só uma pequena parcela da população das grandes cidades brasileiras tinha acesso. A música transitava entre a Bossa Nova, estilo criado por João Gilberto, e sambas modernos e mais tradicionais. Os 
críticos ao movimento da Bossa Nova, os nacionalistas, consideravam que esse novo ritmo era uma cópia do jazz e que isso justificaria o sucesso no exterior.

\begin{abstract}
Lembremos que esse debate, nacionalismo versus entreguismo, não era uma simples questão de gosto. Num país cada vez mais dividido politicamente e que procurava saídas para os seus impasses sociais, culturais e econômicos, a arte e a cultura eram espécies de "laboratório de ideias", campo de elaboração de projetos ideológicos para o Brasil. (NAPOLITANO, 2008, p.33)
\end{abstract}

A esquerda nacionalista criticava a alienação das letras das músicas da Bossa Nova, já que o Brasil apresentava índices de desemprego e de pobreza muito altos. Era como se as músicas da Bossa Nova "fechassem" os olhos para a realidade do país, um entendimento que incomodava os líderes da UNE, comprometidos com a arte engajada, ou seja, aquela capaz de denunciar as mazelas políticas e sociais do Brasil.

Na visão de alguns, a Bossa Nova deveria ser politizada e seu sucesso capitalizado pela arte engajada, o que vai acontecer por volta de 1960 e 1961. Afastando-se do estilo característico de João Gilberto, mas mantendo a qualidade musical, a Bossa Nova passa a incluir em suas letras, personagens reais, favelados que têm seus barracos destruídos pela chuva e até mesmo o amor, recebe um tratamento que rompe com o romantismo, para ser ligado também à dor. Carlos Lyra, um dos que participaram do movimento fundador da Bossa Nova, vai participar então da fundação do CPC da UNE, em 1962.

O CPC apresenta, por meio de manifesto, seu projeto político-cultural alinhado às ideias do PCB. Mesmo não havendo uma adesão dos integrantes do CPC ao PCB, ou seja, mesmo que nem todos os integrantes do CPC fossem comunistas filiados, havia uma identificação destes com a cultura nacionalista de esquerda que o PCB defendia. A defesa do nacional-popular que indicava simultaneamente uma "cultura política e uma política cultural das esquerdas", entendida como a "busca da expressão simbólica da racionalidade, mas que não deveria ser reduzida ao regional folclorizado", que representava apenas parte da nação e nem deveria ser reduzida aos "padrões universais da cultura humanista", como a cultura das elites burguesas. (NAPOLITANO, 2008, p.37)

Segundo Marilena Chauí, a busca pela identidade nacional aflige as classes dominantes e os intelectuais brasileiros desde meados do século XIX. Ainda pequenos aprendemos a relacionar os símbolos da bandeira nacional às nossas riquezas, à ordem e progresso. O verde e amarelo são cores nacionais. Aprendemos 
que somos um povo ordeiro, cordial e formados pela união de três raças. Essa é a mitologia construída pela classe dominante brasileira para "servir-lhe de suporte e de autoimagem celebrativa, enfatizando o lado "bom selvagem tropical" que constituiria o caráter nacional brasileiro na perspectiva das oligarquias agrárias, embevecidas com o mito brasileiro cordial, ordeiro e pacífico". Essa imagem vai incorporar-se ao projeto Desenvolvimentista a partir dos anos 1950, mantendo o passado paternalista e bondoso e prometendo um futuro próspero, sem igual. (1999, p.94-97)

Escrito por Carlos Estavam Martins, o Manifesto do CPC procurava orientar os jovens artistas engajados a ser "povo", mesmo que oriundos de famílias ricas, associando talento e técnica com os conteúdos da cultura popular, construindo assim uma cultura nacional verdadeira, conscientizadora e capaz de combater a exploração nacional e estrangeira. Enquanto o governo Goulart responsabilizava-se pelas reformas de base, o CPC ficava encarregado de ampliar a consciência nacional, fator tido como fundamental para a libertação do país.

Mas antes de atingir o povo, o artista deveria se converter aos novos valores e procedimentos, nem que, para isso, sacrificasse o seu deleite estético e a sua vontade de expressão pessoal, em nome de uma pedagogia política que atingisse as massas, estudantis e trabalhadoras. (NAPOLITANO, 2008, p.38)

O Manifesto do CPC colocava a arte de "elite" acima da arte popular, pelo fato de a primeira ser capaz de transmitir um conteúdo ideológico, alinhado às preocupações nacionalistas. Ainda conforme o Manifesto, os procedimentos formais que deveriam ser o ponto máximo das obras existiriam em dois planos: criação e recepção.

Colocando-se no antigo lugar dos llustrados, a nova vanguarda
"popular" define a cultura por três divisões: a cultura alienada (a da
classe dominante); a cultura do povo (tosca, desajeitada, atrasada,
trivial, ingênua, lúdica, ornamental, sem dignidade artística nem
intelectual, conformista); e a cultura popular-revolucionária
(produzida pela vanguarda que vê o povo como herói, combatente do
exército revolucionário de libertação nacional e popular). A cultura
popular é aquela produzida por artistas e intelectuais que "optaram
por ser povo" e se dedicam à "conscientização do povo". Existem,
portanto, dois povos ou duas culturas populares: o povo atrasado,
inconsciente, e sua cultura trivial e inculta: e o "bom povo", consciente,
culto, avançado, e a cultura vanguardista que o fará realizar as "leis
objetivas da história". (CHAUÍ, 1999, p.109) A recomendação era a de que o "artista-intelectual engajado" buscasse sua inspiração nas "regras e modelos dos símbolos e critérios de apreciação" das classes populares, que inconscientemente eram vetores da expressão nacional. $O$ 
objetivo, de fundo dessa recomendação, seria facilitar a comunicação com as massas, mesmo sob o risco de perda de qualidade da obra produzida. Para isso, os artistasintelectuais deveriam adaptar-se aos defeitos da fala do povo, submetendo-se aos imperativos ideológicos populares, entendendo a linguagem como um meio e não como um fim. (NAPOLITANO, 2008, p.39)

Para o Manifesto o artista ser povo era uma obrigação, porém, alguns artistas que se autointitulavam burgueses, reprovavam essa proposta por considerá-la populista. Carlos Lyra foi um artista que reconhecia ter uma obra política, porém não via a possibilidade de tornar sua produção popular.

A despeito da polêmica, fato é que conhecidos músicos ressaltavam que a música popular seria um importante canal para formar a consciência dos brasileiros sobre o seu país e elevar o gosto popular musical. Para eles, a ideologia nacionalista "era um projeto de um setor da elite que, a médio prazo, poderia beneficiar a sociedade como um todo...". Esse pensamento permanece até 1964, quando o cenário político muda profundamente com o golpe, fazendo com que alguns artistas de esquerda se aproximem mais do modelo popular da cultura brasileira, em reação ao fracasso da proposta do PCB. (NAPOLITANO, 2008, p.41)

Segundo Ridenti, os anos 1960 foram um período de esperança de libertação do terceiro mundo, incluindo o Brasil, que se urbanizava e se modernizava. A esquerda colocava na ação a saída para a mudança da História e para a construção de um "homem novo", que tinha suas raízes no passado, no homem do povo ligado às tradições rurais, um homem ainda não submetido às diretrizes da modernidade urbana capitalista, portanto, uma alternativa à modernização mais humana, menos consumista e menos seduzida pelo fetichismo da mercadoria e do dinheiro. A questão da identidade do povo brasileiro estava novamente em pauta, assim como o resgate das suas raízes e o rompimento com o subdesenvolvimento. Ainda segundo o autor:

Lançavam-se novos olhares para as representações da mistura do branco, do negro e do índio na constituição da brasilidade, não mais no sentido de justificar a ordem social existente, mas de questioná-la. $\hat{E}$ a isso, em linhas gerais, que se pode chamar de romantismo revolucionário brasileiro do período, sem nenhuma conotação pejorativa. (2003, p.198)

O que se buscava na verdade era uma cultura popular genuína, capaz de construir uma nova nação, moderna, ciente dos seus problemas. Mas por questões culturais presentes na sociedade brasileira, o popular é visto de duas maneiras: ora 
relacionado à ignorância, ao atraso, ora como um saber genuíno e de emancipação. Conforme Chauí: "...capaz de conformismo ao resistir, capaz de resistência ao se desenvolvem sob a dominação." (1999, p.124)

\subsection{CULTURA: OS ANOS 1964-1968}

O Golpe de 1964 e a saída sem resistência de João Goulart do governo deixam esquerda e nacionalistas perplexos. Um período de incertezas políticas se inicia e com ele intensos debates nos meios artísticos e intelectuais que procuravam encontrar uma explicação para a derrota.

No início de 1964, o regime militar, que chegava com o golpe, se detém nas cassações de parlamentares e sindicalistas e na dissolução de organizações populares. Artistas ficam sob vigilância, mas ainda com liberdade para criar. $O$ pensamento dos militares era de que se os artistas ficassem restritos ao mercado da classe média, não trariam risco aos seus objetivos.

Essa nova situação leva a esquerda a colocar a formação de uma consciência social de combate ao regime como sua prioridade. A cultura, que ainda tinha um certo espaço de ação, passa a ser estratégica para que a esquerda continuasse a se manifestar. Foi uma época em que a indústria cultural no Brasil passou a ser rediscutida e pôde acomodar obras de alguns artistas engajados.

Segundo Napolitano (2008, p.49), esse fato não significou que esses artistas tenham sido cooptados pela indústria cultural, por verem suas obras sendo consumidas como qualquer mercadoria, pois a discussão sobre a profissionalização do artista e da sua inserção no mercado já vinha desde os anos 1960.

No meio artístico vê-se duas formas de reação ao golpe: o triunfalismo e a perplexidade. Podemos ver o triunfalismo no teatro, com a peça Opinião, que estreia em dezembro de 1964, e que trazia em seu texto uma proposta apostando na possibilidade de uma união de classes contra o regime. Por outro lado, a perplexidade pode ser notada no filme O desafio (1965), de Paulo Cesar Sarraceni, que mostrava a vida de um jornalista de esquerda, deprimido e desiludido política e emocionalmente depois do golpe. (NAPOLITANO, 2008, p.49-50)

A peça Opinião, escrita por Oduvaldo Vianna Filho, Paulo Pontes e Armando Costa, com a música Carcará que se torna sucesso, interpretada por Maria Bethânia, foi a 
mais importante e incisiva resposta do meio cultural ao regime que se instalara no país. O próprio programa da peça, um manifesto escrito pelos autores, esclarecia que a música popular é mais expressiva quando ela transmite uma opinião e está ao lado do povo. De acordo com o manifesto:

A música popular é tanto mais expressiva quando tem uma opinião, quando se alia ao povo na captação de novos sentimentos e valores necessários para a evolução social. [...] manter vivas as tradições de unidade e integração nacionais. (NAPOLITANO, 2008, p.50)

Os protagonistas da peça, uma jovem de classe média, um sambista e camponês do nordeste representavam a união social, base da frente única nacionalista, derrotada pelo golpe. O Opinião, de certa forma, dava continuidade às propostas contidas no Manifesto do CPC, procurava estabelecer um canal popular de comunicação, negava o teatro autoral e a música de elite e se utilizava de pesquisa do folclore brasileiro para compor as músicas e poesias do espetáculo.

É importante frisar que além da peça Opinião, outras peças teatrais que juntavam música, poesia e crítica social foram apresentadas entre 1964 e 1966, como Arena conta Zumbi; Morte e vida Severina; e Liberdade, liberdade, entre outras. Esses espetáculos coincidiam com um período em que os princípios da cultura nacionalpopular estavam sendo repensados, já que depois do golpe o popular era uma tendência que dava sentido ao nacional, ao contrário do que acontecia antes do golpe, em que o nacional representava o popular.

A busca por uma identidade popular pura era um novo norte para os intelectuais nacionalistas, mas que ainda assim não conseguia superar os problemas decorrentes da união entre povo e intelectuais, já que estes, ao falar pelo povo, formulavam um discurso com base em representações simbólicas que não consideravam o mundo real do povo e suas contradições.

A forma assumida pela arte engajada para resolver o impasse entre "ser popular" (buscar inspiração na cultura do povo idealizada) ou "popularizar-se" (no sentido de ampliar sua audiência e comunicar a sua mensagem), acabou conduzindo a novos impasses na medida em que, entre o artista e o povo, se impunha cada vez mais a mídia e a indústria cultural (sobretudo na música popular). (NAPOLITANO, 2008, p.52)

Marilena Chauí considera que sempre houve uma preocupação de artistas e intelectuais em definir o popular, o "verdadeiro nacional", visto sob a ótica antiimperialista, ou, em última instância, o que se buscava era se construir uma 
"vanguarda aguerrida do povo". Peças teatrais, filmes, livros, manifestos diziam para o povo como ele deveria ser, fazer e pensar "para que se cumpram as "leis objetivas da história", trazidas para a consciência popular através da "vanguarda revolucionária"; o popular se torna sinônimo de ação política". (1999, p.108)

O "popular" se torna não só objeto de construção e de exibição, mas ainda se converte em palavra de ordem da ação política, na medida em que se trata de tomar o poder do Estado para criar um "verdadeiro Estado nacional" porque "Estado popular". (CHAUÍ, 1999, p.108)

Opinião, Arena conta Zumbi e $O$ desafio foram uma espécie de catarse para o sentimento de frustração política pós-golpe e ajudaram a reunir jovens de classe média e a construir um sentimento de resistência. O filme $O$ Desafio vai dar início a um período de 'revisão ideológica e estética que o Cinema Novo radicalizou em relação aos valores do nacional-popular, tratado no filme como um conjunto de crenças "perdidas e sem retorno"'. (NAPOLITANO, 2008, p.53)

Mas foi o cinema o principal responsável por fazer uma profunda reflexão sobre a derrota da esquerda em 1964 e por buscar se livrar dos sonhos políticos e ideológicos que estavam por detrás da cultura nacional-popular e sua utopia da aliança de classes. Terra em transe (1967), de Glauber Rocha, resume o fim desse sonho. Segundo Chauí:

\begin{abstract}
É essa indeterminação fundamental do Nacional que é recusada pela ideologia nacionalista. Assim como a teologia e a metafísica sempre se empenharam em oferecer provas da existência de Deus e do Mundo, sejam provas a priori (da essência de Deus ou do Mundo se deduz a necessidade de suas existências) sejam provas a posteriori (da finitude do Mundo e das criaturas se deduz a existência do Infinito criador; da existência do Infinito criador, se deduz a existência do Mundo finito), assim também, substituto moderno da teologia e da metafísica, o nacionalismo não faz senão produzir provas a priori e a posteriori da existência da Nação, como um ser determinado, uma essência, uma substância e uma ideia. Procura-se eliminar o que mais interessa no Nacional, isto é, a indeterminação, sua existência contraditória em busca da unidade que anule as divisões sociais e que não pode cumprir-se. (1999, p.114-115)
\end{abstract}

Diferente da Música Popular Brasileira (MPB), o cinema engajado que apresentava muita dificuldade para se tornar popular, em atingir o grande público, também não tinha compromisso com resultados comerciais.

Depois de 1964, houve uma mudança substancial na área cultural, com a intensificação da entrada do capital estrangeiro no Brasil, que diminui as importações e amplia a produção de grande parte dos bens de consumo no próprio 
país, incluindo a indústria cultural. Segundo Oliven, a chegada da Rede Globo, mesmo que seu início tenha tido o suporte de investimento estrangeiro, vai diminuir a importação de material produzido no exterior devido à colocação no mercado de seus programas que abordam situações típicas brasileiros, que chegam até a ser exportados. O mais importante a notar é que, mesmo sendo produzidos no Brasil e tratando de questões nacionais, os produtos apresentados nos meios de comunicação de massa, em especial a televisão, sofrem uma releitura, concedendoIhes uma formulação ideológica que tenha trânsito fácil. (1984, p.48-49)

Com a ampliação do mercado cultural, a MPB ganha espaço na televisão, e programas e novos intérpretes se destacam no meio artístico nacional. Elis Regina foi um desses casos. A chegada do videoteipe proporciona que a televisão tenha mais recursos de produção e transmissão, aprimorando sua qualidade técnica e produz um incremento de verbas de publicidade. Novelas e programas de variedades são a coqueluche do momento. Os musicais, porém, foram os grandes responsáveis por trazer um novo público e aumentar a popularidade da TV, que até o começo de 1960 ainda eram acompanhados pelo rádio.

Programas semanais de música popular brasileira, como o Fino da Bossa e a Jovem Guarda eram vistos por diferentes públicos, do mais intelectualizado no caso do primeiro, aos "alienados" que seguiam a Jovem Guarda. Mas Napolitano (2008) chama a atenção para o protagonismo que os Festivais da Canção tiveram na televisão brasileira, entre 1966 e 1968, com destaque para o Festival da TV Record que, em 1966, mobilizou São Paulo em torno da finalíssima, que tinha Geraldo Vandré e Chico Buarque como concorrentes e que acabaram empatados em primeiro lugar.

\footnotetext{
Esse segmento vislumbrava, no movimento musical gerado pelos festivais, um tipo de resistência cultural ao regime militar, sobretudo porque valorizava os elementos culturais nacionais e populares. Assim, consagrou-se o termo Música Popular Brasileira (MPB), sigla que se tornou sinônimo de música comprometida com a realidade brasileira, crítica ao regime militar e de alta qualidade estética. (NAPOLITANO, 2008, p.57)
}

Segundo Ridenti, a brasilidade revolucionária poderia ser vista nas obras de Edu Lobo, Geraldo Vandré, e nos seguidores da dramaturgia do Arena, como a peça Arena conta Zumbi e o romance Quarup, de Antonio Callado, de 1967, que enaltecia a cultura indígena e que levava o leitor a pensar o Brasil. Obras como Iracema de José de Alencar e Macunaíma de Mário de Andrade e o clássico Os Sertões de 
Euclides da Cunha, são bons exemplos da brasilidade revolucionária, pois buscam no passado uma cultura popular genuína para "construir uma nova nação, moderna e desalienada". (2010, p.90)

Podia-se ver uma identificação dos artistas engajados com os excluídos, os sem terra que viviam no campo e também nas cidades, representantes do povo brasileiro, que precisavam ser preparados para abraçar a luta política. A arte traria a libertação da alienação, o rompimento com a ordem social vigente, com o capitalismo, traria a possibilidade de se construir um país novo, do futuro, mesmo que construído a partir das tradições do passado. Obras calcadas na brasilidade revolucionária indicam a solidariedade que os artistas tinham com relação ao sofrimento do povo e às condições precárias em que viviam nas grandes cidades. Esse sentimento embutia "...uma idealização do homem do povo, especialmente do campo, pelas classes médias urbanas. Mas ele se ancorava numa base real: a insurgência dos movimentos dos trabalhadores rurais do período". (RIDENTI, 2010, p.91)

\subsection{CULTURA: Al-5, REPRESSÃO E DISTENSÃO}

Como já dito anteriormente, o cinema vai rapidamente se reposicionar frente ao Golpe de 1964 e o novo cenário político brasileiro. Motivos não faltavam: a repressão que se iniciava e a forma como foi criado o INC. Em 1965, em um festival em Genebra, os cinemanovistas fazem um balanço, buscando novos caminhos para o cinema brasileiro e Glauber apresenta sua tese da "Estética da Fome", na qual o cinema se apresenta como pobre, reflexo da miséria existente no país, com uma preocupação revolucionária, conscientizadora, capaz de romper com o "colonialismo" que existente no Brasil. (RAMOS, 1983, p.75-76)

Relevando as incoerências com antigas declarações do mesmo Glauber, a proposta transita entre o nacionalismo e a alienação, sendo que o nacionalismo vinha acompanhado da preocupação de ser uma dominação colonial, ideia fundamentada na tese de Paulo Emílio, dos anos 1960, de que a América Latina continuava a ser colônia e o colonialismo somente era diferente do colonialismo passado porque 0 colonizador havia se aprimorado. (RAMOS, 1983, p.76)

Outro cineasta que também vai analisar o cinema no pós-golpe foi Cacá Diegues. Ele temia que uma crise econômica chegasse ao cinema, que já possuía uma frágil 
estrutura e apresenta uma nova visão do Cinema Novo. Para Cacá, o aspecto miserável, a violência, a conscientização e libertação nacional deveriam ser substituídas e no seu lugar o cinema deveria entregar-se a conhecer a cultura brasileira e, em consequência, conhecer o homem brasileiro, diferente do Cinema Novo, agora acompanhando suas transformações.

Num primeiro momento, trata-se de "tomar o homem como tema, hominizá-lo através dos seus conflitos", dentro de uma perspectiva política ampla de articular um projeto político nacional; e, portanto, os cineastas encontravam-se cheios de certezas diante da realidade do país, procurando integrar o diverso "homem-brasileiro" nesta visão analítica global. (RAMOS, 1983, p.78) 


\section{O REGIME MILITAR NO BRASIL}

Estamos no ano de 1960 e o general Odylio Denys assume o comando do Ministério da Guerra, em substituição ao Ministro Henrique Teixeira Lott, que deixava o posto para concorrer à presidência. Foi quando Ernesto Geisel se torna chefe do gabinete militar e, em 1961, ainda no gabinete, presencia toda a crise desencadeada pela renúncia, oito meses após ter sido empossado como presidente da República, de Jânio da Silva Quadros e a posse negociada de João Goulart.

O clima no país ficava cada vez mais tenso em decorrência da instabilidade política motivada pela renúncia do presidente Jânio Quadros e pela deposição, em março de 1964 do presidente João Goulart, acusado de incapacidade política para governar o Brasil e ser simpático e sofrer influência de sindicalistas e políticos com pensamento de esquerda. Nesse contexto, apoiados pelas elites empresariais, os militares dão 0 Golpe Militar, o início de 21 anos de poder militar no Brasil.

Geisel emerge então como um dos conspiradores de 1964. Faz parte do grupo ligado ao primeiro presidente do ciclo militar, Humberto de Alencar Castelo Branco, um governo que tinha a pretensão de ser temporário, destinado a regularizar a situação do país, de forma a promover uma reorganização das diferentes esferas da sociedade, nos âmbitos político, econômico e social.

Com a instituição do Ato Institucional n.5 (Al-5) ${ }^{26}$, em 13 de dezembro de 1968, fica claramente definido o modelo jurídico ditatorial do regime, deixando para trás uma legalidade constitucional, mesmo que frágil e restrita. Costa e Silva considerava o Al-5 democrático na sua concepção, por traduzir a vontade do povo brasileiro e manter a ordem no país e a ditadura um caminho para engrandecer o homem, sendo a educação o princípio de tudo. Buscava-se disseminar a passividade que conduziria à aceitação do regime.

Assim, o Ato Institucional n. 5 foi o amadurecimento de um processo
que se iniciara muito antes, e não uma decorrência dos episódios de
1968, diferentemente da tese que sustenta a metáfora do "golpe
dentro do golpe", segundo a qual o Al-5 iniciou uma fase

26 O Ato Institucional $n^{\circ} 5$, de 1968, foi o quinto decreto editado pelo regime militar, desde o Golpe de 1964 . Considerado um forte ataque à democracia, o decreto deu poderes extraordinários ao regime e absolutos ao presidente da República, além de suspender garantias constitucionais. Foi uma resposta ao discurso do deputado Márcio Moreira Alves, que acusava o Exército de abrigar torturadores e conclamava a sociedade brasileira a boicotar as festividades de comemoração do "7 de setembro". 
completamente distinta da anterior. Trata-se de reafirmar a importância, como projeto, do que se pode chamar de "utopia autoritária", isto é, a crença de que seria possível eliminar quaisquer formas de dissenso (comunismo, "subversão", "corrupção") tendo em vista a inserção do Brasil no campo da "democracia ocidental e cristã". (FICO, 2004, p.34)

É também com o AI-5 que o autoritarismo recrudesce. Segundo Oliveira:

[...] o regime militar havia desenvolvido uma estabilização conservadora e coercitiva em resposta a uma crise da dominação burguesa. O regime utilizava para sua preservação e par implementar mudanças a capacidade política e intelectual de organização da dominação. (1994, p.28)

Na medida em que o autoritarismo cresce, ações de resistência eram identificadas no próprio "aparelho militar", e mesmo que difusas e pouco divulgadas, resultaram em ações concretas, causando dificuldades num primeiro momento para queo regime potencializasse sua capacidade repressiva e seu arbítrio. Existiam alguns militares, sobretudo os jovens oficiais, que se seguiam cuidando de suas carreiras e se omitiam frente ao que acontecia e também outros, que preferiam por um fim às suas carreiras, passando para a reserva, a terem que encobrir os atos de tortura. Porém, "foram poucos os casos de denúncia ou oposição explícita, o que revela a existência de uma grande quantidade de militares coniventes" com a tortura. (FICO, 2004, p.34)

O maior desafio para as organizações de poder, inclusive as autoritárias ou autocráticas, está na sua busca por legitimização. A adesão e o reconhecimento não são condições para sua existência, mas definem sua relação de poder, ou seja, para uma legitimidade democrática, um poder democrático, uma legitimidade autocrática, o poder a acompanha. (REZENDE, 2001, p.29)

A ditadura buscava legitimar suas ações e ganhar a aceitação da sociedade brasileira com o argumento que o regime era um governo do povo e que a democracia, a despeito das condições políticas do momento, estava vinculada à união de "liberdade e autoridade, ordem e disciplina, combate ao comunismo, defesa da família, da propriedade e da empresa privada", ou seja, valores que justificavam a presença militar no estado brasileiro. A ditadura vai então criar um novo sentido para democracia, no qual liberdade, vinculada à ordem e disciplina e à oposição ao comunismo. (REZENDE, 2001, p.71)

A liberdade que o regime propagava não contemplava dos direitos e da igualdade jurídica, abrindo caminho para a instituição de novos atos institucionais e 
constitucionais, que também eram justificados como sendo uma proteção aos valores que o regime representava.

O regime militar brasileiro utilizou-se de ações autoritárias para conseguir reconhecimento junto aos mais diferentes seguimentos sociais, e mesmo a publicação de atos institucionais e constitucionais não eram vistos, pelo governo, como problemas para a obtenção da aceitação e adesão. "O regime militar havia desenvolvido uma estabilização conservadora e coercitiva em resposta a uma crise da dominação burguesa." (OLIVEIRA, 1994, p.28)

Podemos dizer que o Golpe Militar de 1964 introduziu a lógica do autoritarismo e implementou o fechamento gradativo do regime político. As unidades militares criadas para atender o próprio Regime eram precárias e provisórias, por serem na verdade apenas a substituição dos grupos dirigentes já existentes e a realocação dos vinculados aos grupos dos perdedores a posições inferiores, já que estes não foram totalmente excluídos das instâncias de poder e de decisão.

Segundo Oliveira, as contradições observadas entre o aparelho militar e o regime autoritário, que foram motivação para o projeto de distensão política, já aparecem logo com a vitória do Golpe Militar, em 1964.

A chegada do general Castelo Branco, de posição mais moderada ${ }^{27}$, à presidência da República e, a permanência do general Costa e Silva no Ministério do Exército, uma figura que representava a linha dura, ou seja, responsável pelos inquéritos policiais-militares que eram, na verdade, ritos sumários para justificar cassações e suspensão de direitos civis e políticos, criava um clima de permanente tensão.

Os embates acirrados e por vezes violentos entre diversos setores militares encastelados nos aparelhos do Estado, orientados pela disputa pela presidência, impulsionaram a militarização do Estado e a implantação de um controle repressivo e abrangente sobre a sociedade civil. Setores militares ocuparam a área econômica estatal, seja em razão do seu preparo específico em alguns casos, seja em especial pelo tráfico de influência, pela acomodação funcional (compensações de natureza política) de oficiais que tiveram suas carreiras prejudicadas, pelo acesso privilegiado aos meios de poder ou, ainda, pura e simplesmente pelas oportunidades de corrupção. (OLIVEIRA, 1994, p.32-33)

\footnotetext{
Segundo Carlos Fico, esse lado moderado de Castelo seria um ato de indulgência de seus biógrafos. Estudos mostram que o primeiro general presidente do Brasil proibia atividades políticas dos estudantes, decretou o Al-2, consentiu que militares radicais conquistassem poder político, colaborou na redação e assinou a Lei de Segurança Nacional que institui a noção de "guerra interna", fechou o Congresso Nacional e decretou uma restritiva Lei de Imprensa, além de ser conivente com a tortura, já existente nos momentos iniciais do golpe. "Castelo foi complacente com as arbitrariedades da linha dura, não teve forças para enfrentá-la e permitiu, assim, que o grupo de pressão fosse conquistando, paulatinamente, mais espaço e poder. Essa evolução é essencial para bem caracterizar diversos outros episódios do período, pois informa que o projeto repressivo baseado numa "operação limpeza" violenta e longeva estava presente desde os primeiros momentos do golpe." (2004, p.32-33)
} 
A presidência passa a ser o maior posto da carreira militar, visto que para ocupar a cadeira da presidência, era condição ser um general-de-Exército e aí reside a contradição, na medida em que a Presidência passa a ser a base do autoritarismo político. O regime militar trouxe uma condição inédita para se ocupar a presidência da República, que se torna uma função na qual se fazia necessário possuir a mais qualificação militar da ativa (general-de-Exército quatro estrelas) para ocupá-la. Geisel, mesmo estando na reserva, apresentava essa qualificação e algumas regras foram atropeladas para que João Batista Figueiredo alcançasse tal patente.

A ocupação da cadeira da Presidência da República pressupõe uma luta pelo poder, luta que pode colocar em risco a coesão institucional. Nos processos de sucessão durante o governo militar, esses conflitos produziram "acordos" entre os que pleiteavam o cargo, voltados à divisão de postos de responsabilidade na própria estrutura militar e em órgãos da administração, como autarquias, ministérios, etc.

Isso promovia grandes embates entre grupos de militares que viviam no aparelho estatal, que terminam por incitar a militarização do Estado e intensificar e ampliar a repressão. Via-se também militares ocupando cargos na estrutura estatal, ou para compensar algum prejuízo tido em suas carreiras, ou possibilidade de corrupção.

Os militares também estavam nas posições políticas, principalmente aquelas ligadas à informação e à segurança, como a força policial dos estados, que passaram a ficar subordinadas ao Exército e ter seu comando subordinado a um oficial de patente superior.

\footnotetext{
Tal expansão da presença militar corresponde a um mais alto patamar de mobilização política dos quartéis e ainda ao comprometimento da funcionalidade (e também da previsibilidade, características das instituições burocráticas) da cadeia de comando, proporcionando o surgimento de uma nova e muito importante contradição na instituição militar. (OLIVEIRA, 1994, p.34)
}

O crescimento do poder militar tem reflexos na estrutura de comando da própria instituição, que via diminuir sua mais forte característica, que era a previsibilidade da cadeira de comando. O que se viu então foi um crescimento, com grande autonomia, do aparelho repressivo frente aos centros de decisão militar, e que, beneficiado pelos comandos paralelos e pela disfuncionalidade da cadeia de comando, pode interferir nos rumos institucionais do Estado, resistir à política de distensão e, o pior, se juntar à criminalidade (tráfico de drogas, prostituição e o esquadrão da morte). 
complexa no país - que mesclava polícia civil, polícia militar, militares das três forças e até mesmo bombeiros e polícia feminina - e foi responsável pelos principais episódios de tortura e extermínio. Representou a vitória completa da antiga "força autônoma". As turmas de busca e interrogatório faziam o trabalho sujo que a "utopia autoritária" pressupunha. Assim, em função de suas necessidades intrínsecas, essa polícia política atuava com grande liberdade de ação, até mesmo porque não poderia ser de outra forma, sob pena de perder oportunidades, quebrar o sigilo de operações secretas etc. Mas não se deve confundir a independência operacional com que trabalhava a polícia política com uma suposta autonomia em relação aos oficiais-generais. A tortura e o extermínio eram aceitos pelos comandantes e governos militares, como hoje já se comprovou. (FICO, 2004, p.35)

Um exemplo disso seriam as ações do Delegado Sérgio Paranhos Fleury, conhecido por sua crueldade, que mantinha um sítio, o sítio Fleury, para onde o delegado levava os presos para torturá-los e matá-los, sem que essas prisões tivessem sido notificadas.

\begin{abstract}
Autonomizado com relação ao comando político do Estado, o aparelho repressivo articulou-se com frequência com comandantes militares pela conquista de espaços decisórios, seja no interior do aparelho militar, seja no regime político. Instrumento e ao mesmo tempo resultado da política repressiva do regime militar, o aparelho de repressão tornou-se durante algum tempo uma fonte de poder no aparelho militar e no Estado. E não Ihe faltou o apoio importante de setores empresariais sob a forma de recursos materiais e financeiros, apoio político, prestígio e, ao menos num caso, participação direta na tortura. (OLIVEIRA, 1994, p.34-35)
\end{abstract}

Podemos constatar a contradição interna do regime quando, em abril de 1964, começam as punições, cassações, direcionadas aos militares nacionalistas, dando assim uma falsa sensação de consenso.

Novos conflitos iam surgindo, levando a instituição militar rapidamente para uma crise de legitimidade com relação à sua presença no centro de poder do Estado. Segundo Oliveira (1994) é essa situação que expõe a contradição entre formalizar a existência do aparelho militar, assumindo ações políticas previsíveis e direitos definidos e manter por mais tempo as ações punitivas e, assim, aumentar o controle político da sociedade através da presença militar.

Maria José Rezende considera que o grupo de poder ${ }^{28}$ que existia no Brasil no período de 1964-1984 era composto pelos militares que ocupavam posições de mando em diversos órgãos públicos, que procuravam fortalecer o regime a partir da

\footnotetext{
28 A autora entende que grupo de poder é "uma categoria analítica que expressa um conjunto de relações que iam se constituindo de acordo com as possibilidades e dificuldades de ação política tanto dos seus componentes quanto dos demais setores sociais". (2001, p.10)
} 
criação de certos valores sociais e pela tecnoburocracia civil, da qual faziam parte representantes do capital e do grande capital que podiam estar ou não no interior do governo e também representantes dos partidos políticos, que estreitavam ligações com aqueles por meio de suas atuações no Congresso e nas suas bases eleitorais. (2001, p.8)

É importante salientar que o Exército exerceu também um papel de organizador nas estruturas do Estado e promoveu a ocupação política do aparelho militar vinculada a interesses sociais, que muitas vezes se misturavam com os interesses da corporação. É importante, portanto, reconhecer a forte ligação entre política e o aparelho militar, conforme explica Alain Rouquié:

\begin{abstract}
A expressão 'partido militar', que adotamos e pode parecer inutilmente provocadora, não implica de modo algum o desejo de obliterar a especialidade das instituições armadas, tornando conhecido o desconhecido e confundindo o funcionamento político do braço militar do Estado com o modelo partidário. Essa metáfora não tem outro objetivo, em um primeiro momento, senão o de assinalar firmemente a perspectiva escolhida: as Forças Armadas podem ser forças políticas que desempenham, por outros meios, as mesmas funções elementares que os partidos, e sobretudo que conhecem em seu seio - tanto quanto os partidos, mas segundo outra lógica - processos de deliberação, de tomadas de decisão e até mesmo de união e articulações sociais. Essa ideia de partido militar possui igualmente a vantagem de pôr em discussão o lugar-comum (propiciado pelos próprios militares) das Forças Armadas como um ator unido, senão monolítico - noção inspirada pela esquematização simplista dos traços organizacionais que caracterizam as instituições militares (disciplina,hierarquia, verticalidade). De maneira bastante flexível, o conceito de partido militar enfatiza as situações em que exército e política se relacionam e as instâncias institucionais de inserção da política no aparelho militar (e vice-versa). Concretamente: os partidos militares podem ser verdadeiros partidos fundados por militares para agirem na sociedade civil ou a cristalização de tendências que lutam pelo poder no âmbito da instituição militar e em estruturas políticas próprias do exército, e inclusive na organização militar como um todo, quando certos chefes se esforçam por transformá-la em organização política unificada. (s/ano, p.12-13) (Grifos nossos)
\end{abstract}

A coesão institucional, acerca de uma decisão, como por exemplo, a instituição do Al-5 ou mesmo a escolha de um novo presidente, evitava que os militares do nível intermediário adotassem ações radicais, resultando em acomodação e punição.

Todavia, esta coesão institucional assim obtida em vista de tais finalidades mostra-se passível de alteração radical a curto prazo. Seja porque ela é frágil do ponto de vista político, seja porque mecanismos de natureza militar (como os ligados à renovação dos quadros superiores e à permanência de generais no serviço ativo) determinam que novos chefes militares passem a responder pela 
continuidade do processo político-institucional. (OLIVEIRA, 1994, p.45)

Uma característica do sistema é que ele não é facilmente identificado, não tem uma estrutura que se possa determinar. Essa maleabilidade institucional do sistema deu aos castelistas possibilidade de levar à frente o projeto de distensão, a despeito da resistência do "núcleo duro" do regime e daqueles envolvidos com a repressão.

A concentração de poder político nas Forças Armadas, observada nos governos de Castelo Branco e Costa e Silva, trouxe os elementos para a criação de um projeto de distensão política. Segundo Oliveira (1994, p.63) esses elementos são: 1 - O autoritarismo foi portador da imprevisibilidade de ação do aparelho militar, ou seja, o início de uma crise em uma instituição baseada na hierarquia, mas que, por outro lado, possibilitou ações de resistência e de iniciativas de distensão. 2 - Também se encontram nesses elementos as motivações de ordem democrática que calcularam os "custos políticos" da continuidade do autoritarismo. 3 - Outros fatores importantes merecem destaque, como a ação dos castelistas, racional e arriscada, para implantar a distensão, mesmo que o grupo tenha sido desprezado nos governos Médici e Costa e Silva e a grande capacidade de previsão das Forças Armadas que a fizeram retirar-se do poder, porém, mantendo sua capacidade de pressão, de objetivos e de definição de ação política.

Os castelistas centralizaram em Geisel e no seu chefe da Casa Civil, general Golbery do Couto e Silva, a condução da estratégia de distensão, nos seus diversos aspectos: sobre o ritmo que seria imprimido no processo (lento, gradual e seguro), sobre seus objetivos, sobre como abandonar o autoritarismo, sobre como superar as leis autoritárias, entre outros.

Segundo Oliveira, do ponto de vista de Golbery, a política de distensão se baseava em alguns argumentos: que a "Revolução de 64" não tinha o objetivo de introduzir o autoritarismo no país, que só se instalou devido a pressões externas e, portanto, a necessidade de manter a ordem pública. Segundo o general: A Revolução de 31 de março, sem quaisquer propósitos definidos de
centralização ou de autoritarismo -ela que, afinal, nem pensava em
durar mais que um simples instante de redenção-, seria
gradativamente empurrada a esposá-los, afirmar e reafirmá-los: a
princípio, como simples expedientes temporariamente indispensáveis à
própria manutenção da ordem pública recém-instaurada, ao
saneamento da economia altamente inflacionada e combalida e,
pouco depois, às investidas irracionais de um terrorismo urbano-rural
sem compromissos quaisquer coma realidade nacional; lentamente,
reinterpretados esses meros expedientes como elementos essenciais à
reconstrução nacional e à criação, afinal, da grande potência 
emergente de nossos sonhos. (SILVA, 1981a, p.12)

Ainda em Oliveira (1994, p.59), Geisel entendia, também, que o Estado deveria iniciar um período de "descentralização e de descompressão do poder", através da seguinte estratégia:

...evitem deslocações no sistema e o perigo de rupturas, cuidando
em que o processo, seja de centralização ou descentralização, não
se retarde em excesso num dos campos qualquer em relação aos
demais. Por outro lado, apliquem estímulos bastante fortes no campo
que seja mais propício, segundo a velha tática do aproveitamento
das linhas de menor resistência, para provocar ou facilitar a
progressão, também, em outros campos mais retardados ou
resistentes. Quando não, ao contrário, instituir bloqueios ou
balizamentos bem visíveis naquele campo mais permeável, para
conter aí forças impulsionadoras de maior pressão que possam
resultar desagregadoras ao progresso de conjunto. (SILVA, 1981a,
p.17)

E foi por meio de seus discursos que Geisel apontava a direção e os objetivos buscados pela distensão. Essas mensagens indicavam que o governo não tinha como intenção mudar o "quadro jurídico" antes que fosse possível se estabelecer um novo "ordenamento legal". O governo militar também pretendia antes penetrar na ala oposicionista que havia dentro do partido MDB (Movimento Democrático Brasileiro) de modo a ampliar suas alianças políticas e seu campo de manobra para alcançar com tranquilidade e segurança os objetivos políticos pretendidos.

Sobre o projeto de distensão, Oliveira coloca como hipótese que o grupo ligado a Castelo Branco, os castelistas, mesmo ocupando cargos no governo Médici, criaram ações políticas com o intuito de tomar o poder.

Havia também a intenção, já no governo Geisel, de interferir no sistema, para que pudesse ser implementada uma política de distensão, que era uma estratégia para manter as Forças Armadas como um partido militar e assim proceder ao controle social e prevenir uma crise de legitimidade que teria como consequência uma grave crise social.

O processo de distensão teve início na resistência encontrada nas próprias estruturas do regime, contra o autoritarismo do regime militar. Os militares exerciam o "...papel de intelectuais da dominação que os oficiais militares exercem na condição de funcionários das superestruturas com o propósito de reduzir a zero os fatores imponderáveis". 
funcionam como trincheiras de luta política e ideológica e isto aplicase particularmente ao papel dos militares brasileiros: trincheira defensiva do capitalismo contra as possibilidades (remotíssimas, em que pesem os avisos em contrário) do socialismo; mentalidade organicista conservadora que propugna a ordem como fator de organização e de mudança da sociedade e que encara o conflito social como artificial e, por princípio, manipulado pelos inimigos do capitalismo. Mas capaz, este aparelho militar, de conter contradições com o próprio autoritarismo e de propiciar a emergência de uma ação política racional com o objetivo de reorganizar a vida institucional do país. (OLIVEIRA, 1994, p.30-31)

A política de distensão foi concebida por militares que agiram independentes dos movimentos sociais que se opunham à ditadura militar, enquanto que os movimentos representativos da burguesia eram totalmente favoráveis à continuidade do regime e os movimentos sindicais eram controlados pelo sistema repressivo. Havia uma "oposição" consentida, o MDB, um partido de oposição que compunha o sistema bipartidário, criado pelo Al-2, de 1965, que extinguiu os demais partidos políticos. O MDB, embora tenha ampliado seu espaço político com o aumento em número de prefeituras e de bancadas legislativas, influenciava muito pouco os rumos políticos do país.

Vale destacar que o processo de distensão também começa bem antes da crise econômica que se inicia nos anos 1973-1974, resultado do aumento do preço do petróleo e dos resultados negativos do "milagre econômico", ou seja, o aumento da pobreza e da concentração da riqueza.

\subsection{O SISTEMA POLÍTICO}

A ditadura operou firmemente para desarticular os espaços da política e também para construir uma ideia de democracia que promovia a desvalorização das instituições políticas. Ao mesmo tempo, os militares afirmavam que a sociedade deveria se fazer ouvir por meio de suas instituições, mas desde que fossem aquelas indicadas pelo regime. Até meados dos anos 1970, os setores organizados da sociedade civil eram acusados de cometer ações violentas e arbitrárias e de estarem distanciados das normais legais, ao contrário do regime.

Uma diferença marcante entre o regime autoritário brasileiro e outros similares da América Latina foi o fato de o regime brasileiro manter em funcionamento o Congresso Nacional (exceto no período de dezembro de 1968 a outubro de 1969), 
que trouxe benefícios não apenas para o próprio regime militar, como também para a sociedade civil.

Fato é que os militares, por conta da fraca unidade interna, não foram capazes de extinguir o Legislativo, mas cassou mandatos e direitos políticos, mudou inúmeras vezes a legislação eleitoral, criou mecanismos de repressão, de modo que tanto os partidos, como políticos e o próprio Congresso se tornaram figuras decorativas no cenário político brasileiro. A convocação do Congresso servia para validar os nomes escolhidos para representantes do aparelho militar, tanto na chefia do Estado, como para o governo.

Em fins de 1965 o governo militar entendia que podia interferir nas regras democráticas, como a redução do número de partidos, mas não podia evitar a rejeição dos eleitores aos candidatos ligados à ditadura militar. A promulgação do Ato Institucional n. 2 (Franco Montoro dizia ser o divisor de águas da política brasileira) aprofunda as intervenções e promove diversas alterações na própria legislação eleitoral, buscando obter maioria parlamentar para a Arena, ou seja, manter dentro do Congresso uma oposição controlada e o poder de controle dos militares sobre as principais instâncias de poder. (CARVALHO, 2010, p.223)

O regime mantinha em funcionamento algumas atividades partidárias e a eleição direta para vereador, deputado federal e estadual e senado. Prefeitos não eram escolhidos nas capitais dos estados e municípios, considerados como de segurança nacional, assim como nas estâncias hidrominerais. A ditadura reduziu os partidos políticos a dois, Arena e MDB, que agrupavam pessoas de todas as ideologias e vindas de diferentes bases políticas. Mesmo nesse cenário, cresce o número de eleitores, em razão da chegada dos direitos políticos aos jovens dos grandes centros urbanos.

Entre 1966 e 1978, o eleitorado brasileiro cresceu 51\%. No início da década de 1960, 43\% da população adulta eram inscritos como eleitores; 20 anos depois, esse número atingiu cerca de $83 \%$ dos brasileiros adultos. Segundo Maria D'Alva Kinzo, isso significou que um terço dos leitores no início dos anos 1980 só conhecia os partidos criados durante a ditadura - MDB e Arena. (CARVALHO, 2010, p.224)

Esses números não significam a volta da democracia no Brasil. Na verdade é bom que se diga que muitos brasileiros tiveram sua primeira experiência eleitoral sob o manto do bipartidarismo criado pelo regime militar e essa aparente participação democrática ajudava a construir a legitimidade do regime.

É sabido os efeitos da ditadura na participação política do país, ou seja, o 
afastamento do cidadão da prática política e as consequências dos danos causados pela baixa educação e formação de uma geração inteira de brasileiros. $O$ aumento do número de eleitores indica também que houve sim, mesmo que precariamente, algum tipo de socialização política, mesmo que controlada, ou seja, não sendo conduzida por partidos democraticamente constituídos. O sistema eleitoral do regime dava aos eleitores a sensação de participação política, embora houvesse uma participação ínfima desses eleitores nas questões políticas.

Entretanto, havia um movimento constante e expressivo envolvendo políticos, governistas ou não, focado em confrontar e ampliar os limites definidos pelo governo autoritário e voltados a validar seus mandatos populares. Esses movimentos buscavam também iniciar ou ampliar diálogo e vínculo com grupos organizados ou não, de forma a retomar seus lugares de representantes da sociedade. É importante notar que, mesmo considerando a importância desses movimentos, eles não se dirigiam ao combate à ditadura ou ao regime militar vigente, porém, podem bem ilustrar como os atores políticos agiam, mesmo sob a ditadura.

Para situar melhor a divergência nas interpretações sobre a
importância e o escopo das atividades político-partidárias, é preciso
assinalar que a perspectiva adotada por Grinberg e Motta enfoca não
só as questões institucionais, que estabeleceram uma ordem
autoritária, mas principalmente as ações e práticas empreendidas
pelos indivíduos como políticos e homens de partido, em suas
tentativas de garantir e alargar seu espaço dentro dos limites definidos
pelo regime - seja para afirmar a legitimidade de sua ocupação ou
assegurar a manutenção de suas carreiras. (CARVALHO, 2010, p.227)

Mais à frente, a escolha para presidente, governador e prefeitos das capitais e municípios, de áreas consideradas de "segurança nacional", foi sendo apropriada pouco a pouco pelo regime, ou seja, aos poucos os cidadãos iam perdendo o direito de escolha de seus candidatos, isto é, presidente e governador passaram a ser escolhidos por eleição indireta via colégio eleitoral e os demais por indicação do poder central.

Apesar de haver nesse processo um claro favorecimento aos partidos da situação, acontecia periodicamente uma renovação na Câmara Federal, no Senado e nas Assembleias Legislativas e Câmaras Municipais, já que o regime não podia prescindir do apoio parlamentar, obtido principalmente nos estados menos desenvolvidos e mais dependentes do governo federal, o norte e o nordeste.

Houve uma distorção no sistema de representação dos Estados quando a Câmara dos Deputados estabelece para as bancadas estaduais um número mínimo de seis 
deputados e máximo de sessenta, enfraquecendo a importância dos estados mais populosos. Além disso, também aparece a figura do "senador biônico", aquele indicado pelo partido com maioria de representação na Assembleia Legislativa. O senador biônico foi uma criação do presidente Geisel, na sua reforma eleitoral de abril de 1977, cujo objetivo era reduzir mais ainda a representação política das regiões sul e sudeste brasileira.

Essa época foi marcada pelo empobrecimento da vida partidária. Os dois partidos que ficaram ativos durante o regime, ARENA e MDB, não proporcionavam autonomia no funcionamento do Congresso. Mesmo a Aliança Renovadora Nacional (ARENA), o partido do governo, não conseguia exercer o papel para o qual foi criado. Por isso via-se uma permanente agitação no meio político, no sentido de manter uma relação com o regime autoritário, algumas vezes pelo confronto, outras, pela negociação, pelo diálogo.

Vemos, então, que o cenário político eleitoral, marcado por limites, incertezas e repressão, mudou a forma de ação e de pensar dos atores nele envolvidos, sem que tenha se tornado um obstáculo intransponível.

A presença dos militares no poder de Estado exigiu demais do partido do governo e, por outro lado, limitou a ação do partido "oposicionista". O regime consegue, inclusive, calar a oposição existente na própria ARENA, ao criar o voto de liderança, que submetia parlamentares às decisões da maioria e a fidelidade partidária, um instrumento democrático importante para que parlamentares não se tornem "donos" dos mandatos.

Assim, a ARENA torna-se obediente e dependente do regime. Essa situação permanece até 1974 quando o MDB, tendo como candidato Ulisses Guimarães e Barbosa Lima Sobrinho como seu vice, entra no jogo eleitoral apresentando-se contra o general Ernesto Geisel. Ulisses, convicto de que não venceria as eleições, promove uma campanha nacional contra o regime militar. As eleições de 1974 foram as primeiras eleições a demonstrar claramente a profunda rejeição ao regime militar.

Inverteu-se assim o caráter plebiscitário. Antes, afirmação do regime militar; agora, repúdio a esse mesmo regime que, por esta razão, rejeitou por sua vez o plebiscito e impôs novas restrições à expressão política nas eleições. Uma nova lei relativa ao acesso dos partidos à TV (a Lei Falcão) restringiu ao extremo a participação da televisão nas campanhas eleitorais. Não mais o debate político, mas as fotos dos candidatos acompanhadas de dados pessoais. (OLIVEIRA, 1994, p.56)

O aumento na movimentação política, no confronto entre oposição e governo e na 
atividade partidária, leva Geisel a fazer então um pronunciamento na TV retirando a esperança que o MDB tinha de crescer e assim chegar ao poder. Apesar do clima de "ordem e tranquilidade", as medidas de controle aplicadas pelos órgãos de segurança continuavam sendo postas em prática, com os serviços de informação acompanhando a atuação de grupos comunistas na mídia, nos sindicatos, nos partidos políticos, etc.

\footnotetext{
Este pronunciamento foi utilizado para esclarecer o significado do processo de distensão: A'distensão' é aí apresentada com a conotação exclusivamente política, visando, pelo que se diz, ao indispensável restabelecimento do chamado 'Estado de Direito' mediante a pura e simples revogação do Al-5 e, complementarmente, a revogação do DL-477, a revisão da Lei de Segurança Nacional, a concessão da anistia ampla. (OLIVEIRA, 1994, p.62)
}

Geisel então consegue aumentar a previsibilidade da ação militar e ainda transmitir a João Batista Figueiredo a condução da continuidade do processo de distensão que significou a readequação do aparelho militar para novas funções, sem o peso do sistema.

\subsection{A DOUTRINA DA ESCOLA SUPERIOR DE GUERRA}

O binômio segurança-desenvolvimento é estratégico para os militares, que entendem que o desenvolvimento não se limitava apenas ao plano econômico. Assim era importante ter a preocupação com a qualidade dos agentes que iriam atuar no processo político e econômico, assim como era importante a preservação do patrimônio cultural, que representava a personalidade e a nacionalidade de um povo.

Interessava desenvolver na população aspirações e objetivos que a levassem a um "aperfeiçoamento espiritual e material", através de um trabalho educativo orientado. No fundo, o que se pretendia era trazer a elite com uma visão mais otimista sobre o país, para mais perto do regime.

No contexto da Guerra Fria, os Estados Unidos e a antiga União Soviética, com sua zona de influência, protagonizaram o enfrentamento do bloco comunista versus bloco capitalista, que se desenvolvia de diferentes maneiras: propaganda no campo ideológico, apoio a partidos políticos, envio de dinheiro e armamento a grupos 
militares, ações que reforçavam o antagonismo esquerda-direita.

Para o grupo da Escola Superior de Guerra (ESG), a análise do país deveria partir da realidade brasileira e não de conceitos importados, de modo a refletir propósitos bem fundamentados que pudessem ser aplicados na construção da Doutrina de Segurança Nacional (Doutrina). É o que podemos ver neste trecho do livro Planejamento Estratégico, escrito pelo General Golbery do Couto e Silva, considerado o principal teórico do regime, que indicava a grande preocupação com a segurança nacional:

É que a extensão do fenômeno antes bem delimitado da guerra, a realidade insofismável da "guerra fria" e toda a crueza despótica da política de poder - características lamentáveis, mas não menos reais, da atual dinâmica das relações internacionais - estão a impor o reconhecimento de um estado de emergência de alarmante gravidade a tocar, a rebater nos mais distantes confins do planeta. (SILVA, 1981b, p.23-24)

Vale lembrar que a Doutrina era um instrumental, um norte, para a elaboração e planejamento das ações do Estado. Ela tinha um discurso baseado no conhecimento, voltado para altos padrões morais, cujo intento era demonstrar que seus fundamentos eram alicerçados em proposições verdadeiras, na legitimidade de convicções éticas, conferindo assim maior confiabilidade ao seu método. Não é sem motivo que a Doutrina abarcasse concepções como o caráter nacional, ressaltando. características positivas do brasileiro, como sendo adaptável e pacífico, para se contrapor à imagem de povo individualista, de forma que suas qualidades superariam seus defeitos.

A essência do pensamento da Doutrina da ESG foi resultado da análise da realidade brasileira, que visava fornecer os conceitos e instrumental metodológico para a elaboração do planejamento das ações do Estado, mas também para formar um conjunto de ideias e valores que deveriam conformar uma visão de mundo e determinar certas formas de comportamento à população.

Através da proposição de convicções éticas, a doutrina procurava o convencimento, recorrendo à sustentação na teoria política e na filosofia, de modo a criar um aparato com suposta estrutura científica que, no nível discursivo, não tivesse um caráter dogmático e ideológico, mas fosse capaz de nortear toda forma de construção política e cultural, como modo de valorização e sustentação do regime.

Podemos destacar aqui que algumas das concepções da Doutrina da ESG buscavam identificar inicialmente o caráter nacional no homem, segundo sua própria visão: 
individualismo, adaptabilidade, improvisação, vocação científica, cordialidade e emotividade.

A intenção dos militares de promover depois de 1964 um amplo saneamento moral, político-social e econômico no Brasil, leva o presidente Castelo Branco a criar, em 1966, o CFC, justamente para formular novas concepções, separando educação e cultura, partindo das diretrizes da ESG. Ainda que esta intenção não fosse declarada publicamente, ela nortearia as discussões das propostas para construção de uma matriz ideológica para a cultura.

A criação de novas diretrizes para a política cultural trazia à discussão aspectoschave para o regime, como a questão da nacionalidade e de uma nova formulação da identidade cultural, resgatando e revalorizando toda a nossa história, fatos e mitos históricos e a memória imaterial representada pelos símbolos, muito semelhante ao projeto de Vargas no Estado Novo.

Deste modo, a cultura passa a refletir a doutrina da ESG, ou seja, reflete o essencial do pensamento militar, agora efetivamente presente em todas as estruturas de poder e em todos os níveis da sociedade.

\subsection{O GOVERNO MÉDICI E O PROGRAMA DE AÇÃO CULTURAL (PAC)}

O governo do presidente Emílio Garrastazu Médici (1969-1974) foi marcado efetivamente pelo foco que deu ao crescimento econômico e ao combate à luta armada de esquerda. É, pois, sob o "signo do Al-5 e de uma nova Constituição que se processa a tensa articulação entre as consequências da modernização, como o crescimento da indústria cultural e uma rígida repressão e censura". (RAMOS, 1983, p.89)

Por meio da atuação do seu Ministro da Educação e Cultura Jarbas Passarinho, o governo Médici passa atuar de forma inovadora no campo cultural e a dar maior importância ao cinema. Passarinho se apropria do discurso nacionalista, preconizando que a cultura não deveria ser um instrumento de alienação e deveria estar associada à realidade brasileira e servir para a afirmação do próprio país, ao mesmo tempo em que o Estado mantinha sua política de internacionalização da economia. (RAMOS, 1983, p.92)

O lançamento do PAC e a ampliação das atividades do INL foram os principais 
frutos da gestão de Jarbas Passarinho. Segundo Sérgio Miceli:

O PAC, por sua vez, era não apenas uma abertura de crédito, financeiro e político, a algumas áreas da produção cultural até então praticamente desassistidas pelos demais órgãos oficiais, mas também uma tentativa oficial de "degelo" em relação aos meios artísticos e intelectuais. Fora implantado com vistas a minorar a carência de recursos e de pessoal na área cultural do MEC. Embora não tivesse a função explícita de formular uma política oficial de cultura ou encargos de coordenação a exemplo daqueles conferidos ao Departamento de Assuntos Culturais, O PAC acabou firmando um estilo novo e uma doutrina própria de prática cultural. (1984, p.55-56)

O PAC era um programa versátil, pois dispunha de enorme soma de recursos e podia contratar pessoas de fora da estrutura do MEC, e tendia a diversas áreas de produção, tanto do teatro, como da dança, da literatura, artes plásticas e do patrimônio. O programa deveria cumprir três objetivos principais: "A preservação do patrimônio histórico e artístico; o incentivo à criatividade e à difusão das atividades artístico-culturais; e a capacitação de recursos humanos." (MICELI, 1984, p.56)

A partir da década de 1970 é o Estado que comanda a questão nacional, elidindo obviamente a relação classe-nação, arvorando-se a guardião de uma comunidade indivisa, seus interesses tomados como os interesses de todos. O "nacional" e a "realidade nacional" são vistos como dois todos harmoniosos, que não apresentam nem conflitos internos e nem se contrapõem, em seus fundamentos, à dominação externa. (RAMOS, 1983, p.93)

O programa, lançado em agosto de 1973, passou a funcionar de acordo com o calendário dos espetáculos que seriam apresentados em todo Brasil, como forma de incentivar o intercâmbio regional e foi, aos poucos, se tornando um campo de experiência para a construção institucional do regime e um espaço para o debate dos rumos que deveriam tomar a política cultural oficial.

Cabe ressaltar que a flexibilidade financeira e operacional do PAC permite que ele atue no lugar de órgãos especializados do MEC (o INL, o INC, o SNT), mais rígidos e que dispunham de menos recursos, como um apoio institucional a setores alijados da proteção oficial.

A acolhida dada ao grupo de produtores atuantes em áreas de atividade cultural, que até então não dispunham de espaço institucional adequado, como no caso das artes plásticas e da música erudita, redundou num esforço à legitimidade do PAC e às pretensões de continuidade que começaram a esboçar seus dirigentes. (MICELI, 1984, p.68) 
Pessoas que trabalhavam no PAC e no DAC, bem como artistas e intelectuais interessados em preservar a competência da estrutura organizacional do programa, cogitaram em criar uma outra instituição, nos moldes daquela responsável pelo PAC, mas que englobasse o SNT e o INC e incorporasse a música e as artes plásticas, setores que até então não eram contemplados pelo mesmo.

Porém, havia uma corrente que não concordava com essa proposta, entendendo que o PAC perderia sua flexibilidade administrativa, inclusive ela traria uma diminuição do volume de recursos passados ao programa, através do Fundo Nacional de Desenvolvimento da Educação (FNDE) ${ }^{29}$.

Havia a preocupação, por parte dos grupos interessados na não extinção do PAC, em superar dois impasses: a necessidade de se definir a estrutura organizacional que pudesse receber e administrar, de forma permanente, a relevante dotação orçamentária do PAC e a grande quantidade de atribuições e de áreas culturais que a nova entidade deveria atender. Assim, mesmo havendo entendimento de que devesse ser priorizado o atendimento aos setores até então não contemplados pela estrutura do MEC, temia-se pela continuidade das instituições mais antigas. O PAC foi, assim, um instrumento de desenvolvimento da área cultural oficial.

Tanto o pessoal ligado ao DAC como ao PAC perceberam a tendência de as instituições financiadoras da atividade cultural de ou pulverizar os recursos ou, ao contrário, liberar esses recursos para "grupos específicos" ou para empresas privadas. Assim, com o objetivo de instituir critérios para a liberação desses recursos, foi instituído um plano de ação cultural.

O sucesso dos espetáculos financiados pelo PAC criou um certo desconforto no SNT e IPHAN e na própria direção do MEC na área cultural (DAC), que não recebia o mesmo volume de recursos repassados ao PAC, que se converteu em uma via para viabilizar novos espetáculos e frentes de trabalho no mercado cultural.

A principal programação promovida pelo PAC passa a ser a criação de eventos, organizados por pessoas experientes ou não. "O evento era algo que se produzia no instante do espetáculo, sem a pretensão da obra acabada e única”. Segundo Miceli,

[...] fora preciso acentuar uma postura marcadamente 'executiva', de modo a brecar eventuais resistências por parte da equipe à frente da vertente 'patrimonial' do MEC, então a braços com o desafio de carrear e gerenciar recursos na proporção requerida pelos projetos de restauração de monumentos e obras de arte. $(1984$, p.69)

\footnotetext{
${ }^{29}$ O Fundo Nacional de Desenvolvimento da Educação (FNDE) é autarquia federal criada pela Lei n. 5.537, de 21 de novembro de 1968, e alterada pelo Decreto-lei n. 872, de 15 de setembro de 1969 e responsável pela execução de políticas educacionais do Ministério da Educação (MEC).
} 
Aos poucos a situação de desconforto e a iminência de um possível confronto faz com que o PAC vá sendo reduzido, na medida em que seus núcleos e iniciativas vinculadas ao programa foram sendo extintas. Apenas para ilustrar, eram 130 funcionários envolvidos diretamente com o programa e mais 60 vindos de outros órgãos ligados à área cultural do MEC. Houve, na verdade, um recuo dos responsáveis do PAC para ampliar o conflito e as extinções dos núcleos e de suas iniciativas, para que estas não fossem entendidas como uma interferência no âmbito de ação dos outros órgãos. Sendo assim, uma parcela significativa destes recursos começou a ser repassada a esses órgãos e o PAC a cuidar apenas daqueles setores não cobertos da produção cultural.

Chegava-se então a um momento de decisão: ou o PAC incorporava o DAC, dandoIhe uma configuração financeira e empresarial, ou o PAC se transformaria em nova entidade cultural vinculada ao MEC.

O PAC foi, na verdade, um plano emergencial, sob orientação do Departamento de Assuntos Culturais (DAC), que por questões administrativas e financeiras não tinha possibilidade legal de manejar verbas nem contratar novos quadros para autarquias ou mesmo para o ministério. Como consequência dessas limitações, o DAC perde espaço e poder, ficando muito desgastado.

\subsection{O GOVERNO GEISEL E O PLANO NACIONAL DE CULTURA (PNC)}

No Brasil, os problemas econômicos se agravam. A grande necessidade de importação de petróleo e o aumento dos gastos com essa importação passam a comprometer nossas divisas, fazendo com que Geisel, ao assumir o governo, adote uma atitude drástica, apresentando o II Plano Nacional de Desenvolvimento (II PND), um programa de investimento que optava por aumentar os investimentos ao invés de refrear a economia, sob o risco de o país entrar em um processo recessivo. Além disso, o presidente sinaliza no horizonte com um processo de distensão, que tem por base a formulação do professor Samuel Huntington", que afirmava que "o relaxamento dos controles em qualquer sistema político autoritário pode muitas vezes ter efeito explosivo em que o processo sai do comando daqueles que o

30 Samuel Phillips Huntington, falecido em 2008, foi um controvertido economista, influente nos meios de Harvard, contida em seu trabalho intitulado Métodos de Descompressão Política. 
iniciaram". (SILVA, 2001, p.80).

A democracia, para eles [empresários], continuava atrelada à necessidade de recuperação econômica e de preservação de valores garantidores deste processo. O II Plano Nacional de Desenvolvimento era mostrado pelo governo como o estabelecimento de mudanças graduais na economia. O sucesso do referido Plano, segundo ele [Geisel], poderia compatibilizar o regime com as aspirações denominadas democráticas que emergiam no interior do próprio grupo de poder. (REZENDE, 2001, p.167)

Foi com base nas orientações da Doutrina da ESG que o governo Geisel elaborou um Planejamento Estratégico (PE) para todas as áreas do Brasil, que incluía a cultura, evidentemente, e que embasou a elaboração da Política Nacional de Cultura (PNC), trazendo a ideia da preservação da identidade nacional e da renovação cultural.

A gestão Ney Braga $^{31}$ à frente do MEC finalizou e implantou o inédito e abrangente plano oficial capaz de nortear as ações do governo Geisel na área da cultura, a Política Nacional de Cultura (Política), uma continuidade do trabalho iniciado no PAC.

A importância político institucional desse "ideário de uma conduta" consistiu sobretudo no fato de haver logrado inserir o domínio da cultura entre as metas da política de desenvolvimento social do governo Geisel. Foi a única vez na história republicana que o governo formalizou um conjunto de diretrizes para orientar suas atividades na área cultural, prevendo ainda modalidades de colaboração entre órgãos federais e de outros ministérios. [...] A ideia de uma política nacional de cultura remonta aos tempos pioneiros do antigo Ministério da Educação e Saúde Pública, tendo sido retomada no âmbito do Conselho Federal de Cultura (CFC) no governo de Castello Branco. (MICELI, 1984, p.57)

No decorrer dos anos 1970, ainda puderam ser vistas outras ações importantes do governo federal, que foram a implantação do Programa de Reconstrução de Cidades Históricas (PCH), do Centro Nacional de Referência Cultural e criação da Secretaria do Patrimônio Histórico e Artístico Nacional (Decreto-lei n. 84.198/1979) e da Fundação Nacional Pró-Memória (Decreto-lei n. 6.757/1979), as duas últimas instituições vinculadas ao MEC, que passam a refletir a mudança na tendência

\footnotetext{
${ }^{31}$ Foram também resultado da gestão de Ney Braga a implantação do Conselho Nacional de Direitos Autorais CNDA, (Lei n. 5.988/1973), do Conselho Nacional de Cinema - Concine (Decreto-lei n. 77.299/1976), da Companhia de Defesa do Folclore Brasileiro (Portaria n. 442/1975, depois incorporada à Funarte, da Fundação Nacional de Arte - Funarte (Lei n. 6.312-1975), a reformulação da Empresa Brasileira de Filmes - Embrafilme (Decreto-lei n. 862/1969) e a ampliação da operação do Serviço Nacional do Teatro - SNT (Decreto-lei n. 92/1937).
} 
patrimonial muito presente, desde a década de 1930, no interior do governo federal para a área de cultura.

A PNC foi elaborada por um grupo de aliados oriundos do exército, denominado Grupo Sorbonne, considerado no meio militar como sendo um grupo constituído pelos mais "ilustrados" que os demais, isto é, não somente afeitos às rotinas militares, mas também possuidores de uma visão ampla, devido aos seus conhecimentos políticos e econômicos mais aprofundados. Do grupo, podemos destacar o ex-general Golbery do Couto Silva, importante figura em termos de estratégia política e articulação junto à sociedade civil a época. Fizeram parte também da sua elaboração e redação os principais dirigentes do MEC na gestão de Ney Braga, gestores do DAC e intelectuais pertencentes ao CFC, como por exemplo, Josué Montello, Afonso Arinos de Melo Franco, Gilberto Freyre, entre outros.

Fato curioso é que o plano de governo de Ernesto Geisel foi concebido com a participação de intelectuais e artistas da oposição ao regime que, a convite do presidente, passaram a discutir a futura política cultural do governo. Uma explicação para essa composição seria o fato de que a proposta de Geisel para a política cultural ter um caráter nacionalista e protecionista.

O principal momento da vertente proativa da política cultural do regime militar, que, diga-se, conviveu muito bem com as políticas repressivas, foi sintetizado pelo documento intitulado Política Nacional de Cultura (PNC), elaborado pelo Ministério da Educação e Cultura, em 1975. Ironicamente, poderíamos caracterizar a PNC como a busca de uma cultura "nacional-popular" sem lutas de classes. O teor do texto procurava delimitar um "núcleo irredutível" da cultura nacional autônoma, produzido ao largo dos meios de comunicação de massa. (NAPOLITANO, 2010, p.154)

No intuito de conseguir seus objetivos, Geisel procurou atrair a classe média e certos grupos sociais para perto do regime, de modo a criar uma opinião pública favorável a seus projetos, promovendo a internacionalização de valores, formando uma nova visão de mundo, que fortalecesse o regime materializado, criando instituições e promovendo projetos culturais.

É interessante destacar que a capacidade de articulação e trânsito dos ministros da educação nos governos dos anos 1970 estavam vinculados à importância dada à política cultural, ou seja, o peso que essas políticas tinham para cada um deles e, também, à capacidade desses ministros de obter recursos juntos aos grupos de poder do qual faziam parte. Havia um tratamento diferenciado no governo Geisel, privilegiando alguns, como Ney Braga, enquanto outros ministros sofriam com as 
dificuldades enfrentadas para ter seus pedidos atendidos.

Essa situação confortável encontrada pelos que faziam parte da gestão de Ney Braga era conhecida como "neísmo", que identificava o grupo político mais forte do país, do qual faziam parte figuras proeminentes do primeiro escalão federal, como Karlos Rischbieter, presidente do Banco do Brasil, Reinhold Stephanes, diretor do Instituto Nacional de Previdência Social (INPS), Rui Ribas, sobrinho de Ney Braga e presidente da Companhia Brasileira de Armazenagem (Cibrazem), apenas para citar alguns.

O simples fato de o governo Geisel haver escolhido para Ministro da
Educação e Cultura um militar reformado, cuja carreira política se
consolidara através de sucessivas vitórias eleitorais e que se
beneficiava ainda da imagem de prócer simpático ao patrocínio das
artes evidencia o cálculo de lograr dividendos em função do apoio
concedido aos meios intelectuais e artísticos. Somente um ministro
forte teria condições para assegurar o montante de recursos
necessário ao trabalho de "construção institucional" nas dimensões
apreciáveis em que acabou se desenvolvendo, ou então, para guindar
aos postos executivos de confiança nas instituições culturais porta-
vozes legítimos da "classe intelectual e artística", sobejamente a
esquerda dos administradores culturais típicos até então recrutados
pelo regime de 64. Um Roberto Farias, um Orlando Miranda, um
Manuel Diégues Jr., não teriam chances idênticas numa conjuntura
menos viciada pelo sopro da 'abertura' na área cultural oficial.
(MICELI, 1984, p.65)

Havia, como se pode perceber, uma predisposição à abertura, que chegaria também à área cultural do Estado, e também a ideia de vincular as ações dirigidas aos setores artístico e intelectual às realizações do governo Geisel.

As classes teatral e cinematográfica ficam confiantes com a decisão de permitir que elas escolhessem seus próprios representantes para os cargos de direção de alguns dos órgãos oficiais, acreditando que enfim poderiam, além de expor suas necessidades, também participar da construção das diretrizes das políticas de governo para suas respectivas áreas. Esse otimismo resulta em uma forte adesão de parte do Cinema Novo ao projeto geiselista de 'abertura', depois seguido por outros grupos que também reconheciam os acenos do governo Geisel de aproximação com artistas e intelectuais, concretizado na forma de "concessões generosas ao orçamento das instituições culturais públicas e na ampliação do mercado de trabalho, do qual dependiam esses setores". (MICELI, 1984, p.66)

O trabalho realizado pela Funarte e pela Empresa Brasileira de Filmes (Embrafilme) e as mudanças implantadas no SNT (instituições que representavam as necessidades da área artística e intelectual) foi possível em razão do cenário político 
extremamente favorável e do incentivo recebido de pessoas que ocupavam cargos relevantes na estrutura governamental, que colaboravam ou na captação de recursos, ou no oferecimento de oportunidades de trabalho na área cultural.

No aspecto cultural, no que diz respeito particularmente ao cinema, importa aqui compreender a aparente proximidade, ou um ponto de contato, entre o ideário do Cinema Novo com a PNC, pois ambos trabalhavam conceitos como a "identidade nacional", a "cultura brasileira" ou o "povo brasileiro".

Tanto o Cinema Novo, como a PNC, se utilizavam de um discurso similar para mostrar a realidade brasileira, porém, não idêntico, ao nacionalista militar, que era voltado para a reorganização da economia brasileira, que estava sendo preparada para ampliação de sua produção e para a inserção cada vez maior das empresas brasileiras no comércio internacional.

Com ênfase nacionalista, na defesa do patrimônio, a PNC indicava que o produto nacional, que tinha pouco espaço na indústria cultural, passaria a receber apoio do Estado desde que apresentasse qualidade, inclusive como forma de protegê-lo do avanço da cultura estrangeira. No intuito de promover "a realização do homem brasileiro como pessoa" e, portanto, proteger a cultura brasileira, a PNC atuaria em duas frentes: a regional e a nacional.

A "cultura brasileira", assumida em sua positividade ontológica, deveria corrigir eventuais desvios de rota nos valores fundantes da brasilidade, causados pelo rápido desenvolvimento capitalista. (NAPOLITANO, 2010, p.155)

A PNC tratava de temas tanto de natureza imaterial, como valores, costumes, crenças, convicções, como de natureza material, tais como produção artística, científica, entre outras, além das menções a questões como acervo espiritual e material dos homens, temas também presentes na Doutrina de Segurança Nacional. O PE previa a avaliação de fatores da conjuntura, que eram divididos em quatro categorias: políticos, psicossociais, econômicos e militares. O objetivo era o de formar juízo de valor sobre a realidade e as questões consideradas estratégicas do país. (SILVA, 1981b, p.61-62)

Portanto, ao unir política cultural com objetivos nacionais, a PNC põe fim a um conflito que a visão funcionalista da ESG e sua Doutrina causavam. A PNC propunha o acesso generalizado à cultura e defendia a qualidade, entendida como o bom senso na escolha dos temas e cumprimento dos preceitos da estética acadêmica. A facilidade ao acesso da produção cultural e a exigência de sua "qualidade", permitiram 
elaborar uma política de subsídios à produção e ao consumo, bem como o apoio "às variáveis mais conservadoras, no plano estético, da cultura de oposição". E é claro que, coerente com esses critérios, a PNC não aceitava o "culto à novidade" e o produto cultural massificado, que também eram objeto de crítica da esquerda que via as "vanguardas" como alienadas e os produtos de massa, como sendo de qualidade inferior. (NAPOLITANO, 2010, p.155)

A cultura, norteada pelas diretrizes da PNC, era entendida como "parte integrante e fundamental do bem comum" e existiria no "sentido de trabalhar o homem brasileiro, sua identidade peculiar e específica", e, portanto, as políticas culturais deveriam estar voltadas para cultura brasileira, que deveria ter o olhar dirigido ao regional e ao nacional, além de incentivar a produção cultural, preservando manifestações culturais genuinamente brasileiras, alicerces da identidade nacional. Para isso pretendia-se:

1. Generalizar todo acesso;

2. Garantir a espontaneidade da criação cultural;

3. Garantir a qualidade da criação cultural;

4. Respeitar as diferenciações regionais;

5. Proteger a salvaguarda e a valorização do patrimônio histórico e artístico;

6. Respeitar a liberdade de criação;

7. Estimular a criação;

8. Apoiar a formação de profissionais.

Podemos ver então nas diretrizes da PNC a existência de um maior incentivo ao desenvolvimento da criação e da difusão de diferentes manifestações da cultura, a busca por uma maior aproximação da cultura brasileira com outras culturas e, acima de tudo, a proposição de que um desenvolvimento nacional não seria puramente econômico, mas resultado das manifestações socioculturais.

O grande mérito da PNC estava na sua proposição de que a cultura deveria fazer parte dos projetos de governo, portanto ser pensada a médio e longo prazo, o que em termos gerais parecia bem interessante. Mas estas ideias não eram respostas a uma demanda efetiva e espontânea da sociedade, que sequer foi consultada, mas sim resultante de uma concepção de cultura baseada na avaliação da elite cultural.

No fundo o que se vê é um projeto de ressignificação de um conceito de cultura a ser difundido e monitorado, para fortalecer os ideais e a manutenção do regime. Com o projeto era tolhida a liberdade de criação e o questionamento, visto que o principal agente promotor da cultura brasileira seria o próprio Estado. 


\title{
3.4.1 A gestão Ney Braga: uma política para a cultura
}

Ney Braga (1974-1978) comanda uma profunda reformulação da área cultural, ao implantar a Política Nacional da Cultura, um plano oficial que dava as diretrizes para a participação do governo na área cultural, que reunia uma série de sugestões formuladas por uma comissão, com o propósito de articular a elaboração de consenso em torno de valores que reforçassem as ideias, os conceitos de cidadania, a construção de valor cultural e a identidade nacional e que mantivessem uma coesão da imagem do regime.

Todo projeto cultural tem sua matriz na ESG. O projeto, autoritário, que visava inocular valores conservadores e refratários a qualquer questionamento, aspirava construir uma sociedade feliz, longe de politização e questionamento das formas concentradas e elitizadas da produção cultural.

A gestão do Ministro Ney Braga vai, assim, nortear uma ampla reformulação do setor cultural, contando com a participação de intelectuais e diversos artistas de esquerda em diferentes quadros do MEC, como institutos e autarquias, demonstrando assim uma sinalização do regime em buscar uma maior interlocução com a classe artística e a sociedade civil.

\begin{abstract}
Ney Braga tinha, como vimos, prestígio nos setores intelectuais e artísticos. Por outro lado, ele, que tinha participado, como governador do Paraná, da escolha de Castelo Branco para a Presidência tornando-se, mais tarde, ministro da Agricultura desse governo -, era homem de confiança do presidente Geisel, que o considerava portador de perfil adequado para o MEC por considerá-lo ponderado, hábil e capaz de estabelecer diálogo com os setores estudantis, intelectuais e artísticos. (SILVA, 2001, p.113)
\end{abstract}

Para isso foram nomeadas pessoas com grande respeitabilidade e bom trânsito nos meios intelectuais e artísticos, com declarada inclinação à esquerda, como Roberto Farias e também Orlando Miranda, Manuel Diegues Jr. e Aloísio Magalhães que, em outro contexto, dificilmente estariam presentes em qualquer escalão de um governo militar.

A partir do trabalho de rearticulação dos aparelhos estatais da cultura são criadas diversas instituições, tais como, a Funarte, a Embrafilme, o Conselho Nacional de Cinema (Concine) e é realizada a ampliação do SNT. Tudo isto pode ser visto como 
o início de um processo de ampla mobilização dos gestores da cultura que viria depois acompanhado da formação de quadros estáveis para a elaboração, acompanhamento e avaliação de projetos culturais.

Ney Braga se torna uma figura principal no campo cultural. Bom articulador, transigente, sua pessoa merece análise nesta pesquisa, especialmente pelo fato de ter sido ele um militar da reserva que consegue deixar o ministério respeitado e com a credibilidade junto à classe artística.

\subsection{A EMBRAFILME}

É importante relembrar aqui a trajetória das políticas cinematográficas brasileiras, desenvolvidas desde os anos 1930 com o DIP e do INCE, passando pelas diferentes comissões formadas ao longo dos anos 1950 e 1960 para discutir e formular políticas para o setor cinematográfico, como a Comissão Federal de Cinema (1956), o GEIC (1958), o Geicine (1961) e a Carteira de Auxílio à Indústria Cinematográfica do Rio de Janeiro (1963), iniciativas que, direta ou indiretamente, interferiram e que ilustram a trajetória da produção cinematográfica do Brasil e que anos mais tarde inspirariam a criação do INC.

O INC, criado em 1966 no governo Castelo Branco, primeiro governo militar pós1964, estabelece que a censura a filmes é assunto da União e define como política de Estado a produção, distribuição e exibição de filmes nacionais. $O$ Instituto também fortaleceu a formulação de uma política mais consistente para fomento do filme longa metragem, do filme educativo, além de proceder a implementação e a sistematização de um arcabouço de regras para controle do mercado: desde a estatística e o cadastramento de empresas até a fiscalização.

Além disso, devemos destacar que com o INC foi realizada uma alteração na Lei da Remessa de Lucro (1962), que definiu que empresas estrangeiras de distribuição cinematográfica deveriam transferir obrigatoriamente $40 \%$ do imposto devido para o instituto, caso esse montante não fosse aplicado na produção de filmes brasileiros. Em setembro de 1969, em plena vigência do Al-5 é criada outra empresa estatal para dar suporte à atividade de difusão do filme brasileiro no exterior, a Empresa Brasileira de Filmes, a Embrafilme.

A Embrafilme, uma empresa de economia mista ( $70 \%$ pertencia à União), que mais 
tarde, em 1976, incorpora as atividades no INC, com a ampliação das suas atribuições para financiamento, coprodução e distribuição, teve um papel fundamental para a área cinematográfica e, a partir de 1973, passou a atuar na distribuição. O primeiro filme por ela distribuído foi São Bernardo (1972), de Leon Hirszman, homem do Partido Comunista, filme que abordava o tema do autoritarismo e as relações de poder. O tratamento que teve o filme foi o esperado: retido na censura por longos meses, causou prejuízo ao diretor e levou a produtora Saga à falência.

Com relação à Embrafilme, devemos destacar que o regime pretendia tornar mais dinâmica a produção cinematográfica. O objetivo era o de “...tornar a produção melhor e mais competitiva, "dando-Ihe base artística" (SILVA, 2001, p.136), com a Embrafilme, portanto era imprescindível ampliar suas atribuições, abrindo o seu campo de atuação para além da distribuição, financiando a produção cinematográfica nacional, contando com a efetiva participação de representantes da classe cinematográfica, tanto na gestão, quanto no desenvolvimento de políticas para o setor. Tudo isso refletiu no apoio à produção de filmes históricos e adaptações literárias, foco de estudo desta pesquisa.

Os militares também viam o controle da produção cinematográfica brasileira, através dos filmes educativos e de longa metragem, como uma das estratégias relevantes para se disseminar valores e padrões de comportamento na sociedade brasileira. Para dar curso a essa estratégia, Roberto Farias foi o escolhido para dirigir a Embrafilme pelo bom relacionamento que o cineasta tinha com a classe cinematográfica. Essa facilidade de Roberto Farias para dialogar com seus pares contribuiria para a elaboração de uma política de defesa do cinema nacional, que previa a exibição compulsória de filmes e a abertura e expansão do mercado cinematográfico, entre outras coisas.

\subsubsection{A gestão Farias}

Em 1974, Roberto Farias assume a Embrafilme com a aprovação explícita da classe cinematográfica, estreitando o vínculo entre cinema e Estado, bem como com o 
grupo do Cinema Novo. Segundo Nelson Pereira dos Santos ${ }^{32}$ :

O que aconteceu foi antes do Geisel. O grande negociador de tudo isto foi o Carlos Diegues, que o pai dele era o Secretário de Cultura [sic], o homem do Ministro para as atividades culturais. [...] Antes dele, houve uma relação também através do Ministro Veloso, que participou do governo Médici e continuou Ministro do Planejamento no governo Geisel. (AMANCIO, 2000, p.41-42)

No seu livro Artes e Manhas da Embrafilme, Tunico Amancio considera que o cinema estatal brasileiro em sua época de ouro (1977-1981), nos oferece uma boa compreensão do período da gestão Farias no que se refere às políticas e estrutura de fomento da empresa, além de trazer informações sobre toda a trajetória da construção das estruturas criadas pelo Estado brasileiro para o cinema nacional.

O autor, que trabalhou na Superintendência de Produção da Embrafilme (Suprod), faz uma imersão na gestão Farias na empresa, mostrando suas contradições. Segundo ele relata, se por um lado Farias buscava tratar os problemas da classe cinematográfica, por outro, ele a insere em um sistema de coprodução assumindo o risco dos investimentos nos projetos e acabando por ter que arcar também com a comercialização dos filmes, aumentando a responsabilidade da Embrafilme, já que estas atividades eram realizadas pelo setor privado.

A mudança no modelo gerencial e, sobretudo, nas formas de financiamentos dos filmes são marcas da gestão Farias, que manteve o modelo tradicional (modelo bancário, mas com juros subsidiados), porém criou mais duas outras modalidades: investimentos de até $30 \%$ do orçamento e a retenção de $50 \%$ da renda e $100 \%$ do prêmio até o ressarcimento do capital investido na realização como coprodutora, denominado de "Avanço sobre a renda de filmes brasileiros na distribuição" (Avanço sobre a Renda).

A ideia de Farias era imprimir um novo conceito no mercado cinematográfico brasileiro, ou seja, o de que "Cinema era risco". Como ele sabia que as regras de mercado para financiamento apresentavam prazos e juros altos, condições inviáveis para a atividade cinematográfica, seu entendimento era de que o Estado tinha que correr o risco do mercado. Nas palavras de Roberto Farias ${ }^{33}$ :

Apesar do financiamento da Embrafilme ser muito atraente, havia uma inadimplência muito grande, as pessoas não pagavam. Não eram todos e os que pagavam se contavam nos dedos [...]. Ainda assim as pessoas que pegavam financiamento ou não faziam o filme

Entrevista concedida ao autor em 1969, no Instituto de Arte e Comunicação Social (IACS).

3 Entrevista concedida ao autor em 30 de outubro de 1989, no Rio de Janeiro. 
ou não pagavam o financiamento. Havia os que não pagavam por pouca vergonha e os que não pagavam porque entendiam que o Estado tinha uma responsabilidade de financiamento à cultura... (AMANCIO, 2000, p.47-48)

Pelo que se pode perceber, o grande problema na sistemática do "Avanço sobre a Renda" era a falta de cobrança das dívidas dos tomadores dos empréstimos, os responsáveis pela realização do filme, a não apresentação da prestação de contas e também a não execução penal por apropriação indevida de dinheiro público. Resumindo, havia claramente uma falta de compromisso com o uso do dinheiro público, misturada com atitudes paternalistas e oportunistas.

Nesse modelo proposto pela Embrafilme, a empresa investia, cada vez mais, grandes somas de dinheiro nos filmes, assumindo todo o risco do negócio, isentando o cineasta de qualquer responsabilidade, além da simples conclusão do projeto cinematográfico. Enfim, uma situação muito problemática.

Segundo Roberto Farias ${ }^{34}$ : Ao adotar esse novo modelo, "A ideia foi a de fazer com que o próprio filme fosse garantia do retorno à Embrafilme, a garantia do produtor ou do realizador cessaria quando ele entregasse o filme." (AMANCIO, 2000, p.50)

Na visão de Antonio César Costa, superintendente de produção da Embrafilme, no modelo de Farias quem determinava o processo era o diretor do filme, o que na prática permitia a participação integral do realizador na elaboração da obra cinematográfica. Segundo Antonio Cesar ${ }^{35}$ “....a palavra-chave é o diretor de cinema. Das administrações anteriores, para o Roberto é o seguinte: agora quem dá as cartas é o diretor". (AMANCIO, 2000, p.51)

Nessa gestão substitui-se o produtor pela empresa produtora, classificada pelo seu porte, mantendo-se a pessoa do diretor e do diretor estreante, além de ser criada a Carteira de Coprodução de Filmes Históricos, que tinha a participação da Embrafilme, seja como coprodutora ou mesmo como distribuidora.

Podemos destacar aqui que, além das ações já citadas, outra que teve um resultado relevante foi o aumento dos dias de exibição de filmes nacionais no circuito, a Lei da Cota de Tela, que determinava 140 (cento e quarenta) dias de exibição em substituição aos 84 (oitenta e quatro) dias antes exigidos.

É importante registrar que a gestão Farias, por ter como premissa uma ampla intervenção estatal na área cinematográfica, nunca foi bem vista pelo setor exibidor, que era avesso à interferência estatal, por razões óbvias, já que era norteado pelas

\footnotetext{
34 Idem.

35 Entrevista de Antonio César Costa concedida ao autor em 31/05/84 em Niterói, RJ.
} 
regras da iniciativa privada.

Os desconfortos já começaram a aparecer com a criação do Concine, órgão criado na gestão de Ney Braga, para regular a atividade cinematográfica, que anteriormente ficava a cargo do INC. Uma de suas resoluções, a chamada Lei da Dobra, de 10 de março de 1977, previa a permanência de um filme brasileiro em cartaz na segunda semana, caso ele tivesse superado, atingido ou igualado à frequência do semestre anterior na mesma sala. Dario Correia, ex-assessor jurídico da Embrafilme, comenta:

\begin{abstract}
Então, são as três receitas institucionais da EMBRAFILME. O ingresso padronizado já era cobrado anteriormente. Contra $O$ ingresso padronizado já havia uma série de mandados de segurança de exibidores, principalmente. Não contra o valor do ingresso, que sempre foi baixo, mas contra a forma de controle que a venda de ingresso embutia. À medida que você vende o ingresso, instala uma máquina registradora, uma roleta - e a EMBRAFILME fornecia isso, a EMBRAFILME ficava com um grande controle da renda. (AMANCIO, 2000, p. 59-60)
\end{abstract}

Sobre a Lei de Dobra:

Quando o CONCINE regulamentou a obrigatoriedade de exibição do curta metragem e exatamente quando da ameaça do Jack Valenti ${ }^{36}$ aos produtores em Brasília, a partir daí as distribuidoras estrangeiras também começaram a fazer mandado de segurança contra o curta metragem. Porque aí pioraram, você não tinha só os exibidores de casa, você ia ter também a renda dos estrangeiros, a quem não interessava ter revelada essa renda, não só para efeito de remessa como também para efeito de [...] não sei, eles não tinham interesse que essa renda fosse revelada. (AMANCIO, 2000, p.60)

Ao longo da gestão Farias, a Embrafilme passa por inúmeras reformulações, chegando a alterar seu organograma em 1977, criando a Superintendência de Produção (Suprod), que incorporava o Departamento de Análise de Projetos (DAP), até então vinculado à Superintendência de Comercialização (Sucom).

Farias tinha um objetivo bem claro ao criar a Suprod: evitar, por intermédio da criação de uma série de normas, qualquer ingerência política sobre a escolha dos roteiros, tornando a escolha técnica, através de uma avaliação conjuntural da proposta, da capacidade da produtora, a partir de critérios pré-estabelecidos pela

\footnotetext{
36 Jack Joseph Valenti (1921 - 2007) foi presidente da Motion Picture Association of America (MPPA), exercendo um mandato de 38 anos. Durante seu longo mandato Valenti desenvolveu a supervisão da indústria cinematográfica norte-americana, foi o responsável pela criação de um sistema de classificação de filmes e, principalmente, um grande lobista em Washington para os estúdios de cinema de Hollywood e produtores independentes, no período que vai de 1966 a 2004.
} 
própria Embrafilme.

Já o trabalho de distribuição ficou vinculado à Sucom, então dirigida pelo cineasta Gustavo Dahl. Apesar da costumeira dificuldade enfrentada na exibição, Dahl, por contar com um bom aporte de verba para divulgação dos filmes, obteve expressivos resultados na sua gestão. Foram 83 longas apoiados pela Embrafilme entre 1970 e 1973.

A Embrafilme vai então ser responsável, até o final do regime militar, pela produção, coprodução e/ou distribuição de muitos filmes de sucesso, inclusive os dirigidos por cineastas identificados com a esquerda, como por exemplo Dona Flor e seus dois maridos (1976), de Bruno Barreto; Dama do lotação (1978), de Neville de Almeida; A idade da terra (1980), de Glauber Rocha; Pixote (1981), de Hector Babenco; O homem que virou suco (1980), de João Batista de Andrade; Prá frente Brasil (1983), de Roberto Farias; e, Eles não usam black-tie (1981), de Leon Hirszman. (NAPOLITANO, 2010, p.156)

A Embrafilme, portanto, inova ao considerar o filme como um risco, como um modelo de mercado, financiando até $30 \%$ do filme e participando dos lucros. Sua atuação também desnuda a complexidade que havia por detrás da política cultural vigente que, fruto de um governo militar e de direita, apoiava a realização de filmes claramente de esquerda, que apresentavam críticas ao sistema e ao capitalismo, como o Prá frente Brasil, que abordava e mostrava a questão da tortura de cidadãos indefesos. Esses filmes causaram grandes constrangimentos dentro governo por conta da reação das forças armadas. Prá frente Brasil foi um deles e foi também pivô de uma profunda crise interna na própria Embrafilme. (NAPOLITANO, 2010, p.156-157)

É importante lembrar que o cinema promovido pela Embrafilme passou a ser visto como o promotor da cultura, dos valores, dos personagens e dos fatos históricos brasileiros, eliminando elementos de contestação que iam contra a formulação ideológica do regime e do projeto cultural embutido na PNC, ou seja, autoritário e voltado a construir uma matriz cultural calcada em certo consenso, mesmo descolada da realidade.

Essa relação questionável que existia entre Estado e o cinema deixou suas marcas, principalmente entre os mais jovens que não aceitavam a ajuda oficial e a sua imposição de uma produção culta, mais séria. Houve então uma reação de protesto, a adesão à estética marginal, mais provocativa e que rompia com o sagrado, mais alinhada à produção da "boca do lixo", com seus filmes eróticos e de baixa qualidade. 
(NAPOLITANO, 2010, p.157)

O que podemos depreender é que a década de 1970 foi tomada por contradições resultantes das estratégias políticas culturais oficiais e por mudanças da vida sociocultural. Havia uma consistente oposição no próprio mercado, que teve um suporte ambíguo por parte do Estado, o mesmo que controlava a produção através da censura e ao mesmo tempo promovia o crescimento do consumo cultural ao criar um mercado nacional de cultura.

[...] pode-se afirmar que a adesão a um nacionalismo mitigado, mesclado com a valorização da "herança cultural" ocidental, possibilitou a convergência de instituições, circuitos e agentes culturais situados em campos ideológicos opostos. Estado, mercado e produtores culturais de esquerda, num processo pleno de tensões e negociações, acabaram por convergir num ponto: a necessidade da defesa da "cultura nacional" e da "valorização do produto brasileiro". O Estado participou desse processo de convergência, por razões de segurança nacional. (NAPOLITANO, 2010, p.165-166)

O autor também destaca que não é possível entender o embate cultural entre Estado e sociedade dos anos 1970 apenas considerando dois aspectos: o controle e a cooptação do sistema político-econômico ou a resistência cultural. Napolitano (2010, p.176) também arrisca afirmar que a limitada eficácia da política cultural da esquerda pode ter relação com o sucesso de sua inserção na lógica do mercado, obrigando-os a negociar com os empresários os limites impostos aos seus trabalhos, já que esses mesmos empresários temiam um rompimento com o governo.

Por outro lado, admitindo-se o princípio de que o consumo cultural, via mercado, cria e reforça identidades políticas e sociais, em que momento essas identidades simbólicas se transformariam em práticas efetivas de afirmação de cidadania e construção de projetos políticos alternativos à ordem vigente, questão fundamental em contextos autoritários? (NAPOLITANO, 2010, p.167-168)

\subsection{CULTURA COMO LEGITIMAÇÃO DO REGIME}

O Golpe de 1964 traz consigo uma época de incertezas. A esquerda, que acreditava nas propostas de mudança do governo João Goulart, ficou perplexa com a queda de um governo eleito com um significativo apoio popular. De 1964 a 1968 os debates 
buscavam compreender a nova conjuntura nacional e encontrar novos rumos para a atividade cultural.

Com o advento do Golpe de 1964 os militares passam a imprimir uma nova visão, claramente ideológica, no que se refere ao campo cultural, justificando que a completude da "revolução" dependeria não apenas dos incentivos à educação, mas também de que o governo se ocupasse dos problemas existentes na cultura nacional. Mas, ao contrário, nesse mesmo período o governo militar não se ocupou da classe artística e nem dos intelectuais, pois sua prioridade era extinguir as organizações populares e perseguir lideranças políticas, sindicais e também os parlamentares. Isso aconteceu porque os militares avaliaram que, com o fim das organizações de classe tidas como "perigosas", a arte engajada seria consumida por quem pudesse comprá-la, de forma que o próprio mercado se encarregaria de limitar sua divulgação e, por conseguinte, o acesso a ela também. Portanto, o que se viu nesses anos foi uma controlada e vigiada liberdade de expressão.

A repressão que se inicia depois do Al-5, em 1968, era praticada por grupos oficiais e não oficiais, e funcionava como um mecanismo para difundir o medo e incentivar a imobilização política da população, sobretudo nas pessoas mais informadas e atuantes, ou seja, vivia-se no Brasil, conforme bem traduz Napolitano, a "experiência do autoritarismo" (2006, p.16).

\begin{abstract}
A tecnocracia despolitiza as questões sociais e exclui o setor popular, suprimindo a cidadania. Enfim, este tipo de regime "estatiza a nação", tendo como consequência uma dominação explícita, que dilui as suas mediações consensuais, manifestando-se sob a forma de coação física e econômica. O que o regime espera da sociedade é um "consenso tácito", onde predomine a apatia, a despolitização e "uma existência diária privatizada". (NAPOLITANO, 2006, p.14)
\end{abstract}

A linha dura facilitava a vida dos tecnocratas, que podiam decidir sobre a política econômica do país sem considerar a opinião pública. Havia uma ligação entre estes e os militares, ou seja, os militares garantiam a permanência dos tecnocratas no governo, pois eles garantiriam o funcionamento e o crescimento da economia, uma questão fundamental que legitimava o regime.

A partir de então, a cultura da esquerda passou a sofrer com o controle do Estado sobre sua produção. Censura e repressão chegaram ao jornalismo e às artes como um todo. Nomes conhecidos do meio artístico foram perseguidos e presos pelos militares e depois deixaram o país. Uma publicação consegue driblar o cerco da censura: o jornal O Pasquim (1969) que, além de ser uma inovação no aspecto 
jornalístico, também foi capaz de enganar a censura com suas matérias.

Essas ações de "resistência" seriam então consequência dessa "experiência autoritária", uma nova consciência que indicava diferentes caminhos de atuação política. As ações de "resistência" não tardam a se tornarem coletivas, colaborando assim para a politização de espaços alternativos, na medida em que o regime militar havia conseguido esvaziar espaços públicos próprios à participação política, como os sindicatos, as ruas, a imprensa e as instâncias de representação.

No campo das artes, essas resistências políticas aconteceram fora dos espaços tradicionais de ação e pensamento. Enquanto a dominação, conduzida pelo Estado, seguindo a Doutrina de Segurança Nacional, se utilizou de práticas de poder regidas por uma lógica de despolitização, disciplinarização e privatização da vida social, os movimentos sociais e populares e as entidades civis, como um todo, atuaram na abertura de outros espaços públicos. (NAPOLITANO, 2006, p.16)

Em agosto de 1969, a doença do general Costa e Silva e sua substituição por uma junta militar, depois da proibição de que seu vice-presidente o substituísse, coloca o país em uma crise política. Em 23 de outubro de 1969, o Congresso é reaberto e confirma o nome de Médici para presidente, que assume prometendo ser um governo democrático e voltado a fazer do Brasil uma grande potência, mas que se contradizia ao alertar que não permitiria nenhuma crítica ao regime ou ao movimento de 1964. Era na verdade um aviso para que a sociedade brasileira aceitasse as regras que o regime ditava. A partir de então, o regime fica mais violento e busca ampliar a todo custo, o apoio da classe média às suas ações.

Se o golpe militar teve apoio de setores civis, liberais hesitantes ou autoritários assumidos, o recrudescimento da repressão quatro anos depois, por meio do Ato Institucional n. 5, não teve o mesmo espectro de apoio civil, potencializando o fosso entre Estado e sociedade. (NAPOLITANO, 2010, p.148)

Como já vimos, o crescimento econômico, o acesso da classe média a bens de consumo foram fortes argumentos para aumentar o prestígio do governo Médici junto a ela. A exemplo do governo de Vargas, que se valia dos trabalhos do DIP para divulgar suas ações, o governo Médici também vai se utilizar da propaganda oficial para divulgar seus feitos, criando a Assessoria Especial de Relações Públicas (AERP), que seria a encarregada de desenvolver e coordenar toda a atividade de comunicação, de modo a divulgar massivamente o regime, desviando a atenção do seu lado truculento. 
A AERP elegeu a televisão como o principal meio para levar à sociedade imagens de um Brasil próspero, imagens essas acompanhadas de slogans fortes, de caráter nacionalista. Também a terceira vitória do Brasil na Copa do Mundo do México, em 1970, trouxe um clima de euforia e consolidou um ambiente perfeito para o regime divulgar tais slogans: Pra frente Brasil; Eu te amo meu Brasil; Brasil, ame-o ou deixeo; Ninguém segura este país, só para citar alguns.

\begin{abstract}
Neste último exemplo, a AERP conseguiu inclusive a façanha de criar, através do slogan "Ninguém segura este país", a ideia da articulação da genialidade da nação brasileira com o "milagre econômico", embuste que começou a ficar desmascarado quando a nação passou a ser dar conta que o futebol não segurava mais este país. Entretanto, a crescente intervenção do Estado no futebol evidencia sua importância simbólica e ideológica. (OLIVEN, 1984, p.50)
\end{abstract}

Já em 1971, o governo Médici lança seu Plano Global de Comunicação Social, elaborado pela AERP, que define os objetivos da propaganda desse governo, dos quais podemos citar: mobilizar da juventude, desenvolver o amor à pátria e a confiança no governo. Esse foi um período em que repressão, censura e propaganda, conviveram harmoniosamente e ainda conseguiram convencer boa parcela da população de que o Brasil precisava de um governo forte para atingir o desenvolvimento. (SILVA, 2001, p.63)

No início dos anos 1970 já começa a ficar evidente que o regime perdia sua legitimidade e que uma crise se iniciava. A eficiência do modelo econômico foi sendo cada vez mais questionada na medida em que se ampliava a concentração da renda no país e ficava fora de controle a estatização da economia. O Brasil se vê diante de uma crise, agravada pela dificuldade do Governo Federal em estancar o processo inflacionário e o endividamento externo, na verdade dois objetivos nunca alcançados. As manifestações de rua de 1968 e a derrota nas eleições de 1974 eram indicadores de que a insatisfação aumentava entre aqueles segmentos que até então apoiavam o regime, como a classe média e os empresários.

Esse quadro traz grande desgaste social e a queda da eficiência operacional das políticas públicas mais importantes. A saída seria então a busca por políticas sociais mais abrangentes e operacionalmente mais eficazes. Segundo Falcão:

Ora, isso não foi possível sem que ocorresse ao mesmo tempo uma liberalização do controle político e do compromisso ideológico que o "sistema" exercia sobre burocracia civil, seus planos e programas, sobretudo na área social. Em outras palavras, quer por pressão do 
voto, dos movimentos sociais e da reorganização da sociedade civil, quer pela necessidade de o regime se modernizar para se manter (e seguramente por ambas), o fato é que, a nível do Estado, criam-se espaços para políticas públicas socialmente mais abrangentes, ideologicamente mais autônomas e operacionalmente mais eficazes. Por seu lado, esse processo tem como pano de fundo a crise da aliança social de sustentação do regime, e os esforços e contraesforços para consolidar novas alianças. (1984, p.31)

O regime militar mantinha firme a ideia de conseguir obter um consenso entre as instituições sociais por meio de uma estratégia psicossocial. Era um processo de convencimento para que a sociedade interiorizasse determinados valores e passasse a colaborar com o regime, que sabia da importância de uma opinião favorável àquela suposta democracia. No fundo o que se pretendia era que as instituições sociais se adequassem às instituições militares e também tirar das instituições políticas a tarefa de estimular a participação.

A ideia de condicionamento era, por certo, reveladora desse processo e significava que o regime estaria empenhado em fazer com que as diversas instituições da sociedade associassem os princípios básicos estabelecidos pelo regime em vigor. A resposta dessas instituições às pressuposições dos governos militares sobre desenvolvimento e democracia deveria, então, expressar continuamente este processo de busca de internalização dos valores da ditadura. (REZENDE, 2001, p.113)

Ao final dos anos 1970, os militares, vitoriosos politicamente e isolados, começam a perder a construção da memória para os movimentos culturais. Por outro lado, a esquerda, derrotada politicamente e que protagonizava os projetos culturais, teve êxito em se sobrepor à memória social dominante, oferecendo uma versão heróica da resistência cultural. (NAPOLITANO, 2010, p.148)

A cultura, que não tinha sido o foco principal no período inicial do regime, que estava mais preocupado com as questões econômicas e de segurança, passa a receber atenção e se juntar às questões do crescimento econômico e de combate à subversão. O governo militar buscava alcançar o desenvolvimento e uma ordem social por meio da disseminação de valores cívicos e morais, de modo a impedir a propagação de ideias subversivas. Para que isso fosse possível, era preciso, então, adotar medidas pedagógicas que levassem a sociedade a agir de maneira "adequada", ou seja, que as ações do povo brasileiro fossem pautadas em valores que fortalecessem o caráter nacional. Vanderli Maria da Silva observa:

A necessidade de promover uma tal reorganização das várias 
esferas da sociedade nos parece estar de acordo com a ideia, muito difundida no governo e nos círculos que apoiaram o Golpe de 1964, de que um dos objetivos do movimento seria o de promover um amplo e necessário saneamento - moral, político, social e econômico - da sociedade brasileira. (2001, p.144)

governo via, assim, na cultura, um componente estratégico capaz de levá-lo a reconquistar o apoio dos grupos que haviam dado sustentação ao golpe e que, naquele momento, sentiam-se decepcionados por terem sido atingidos pela crise econômica e também uma importante aliada na reconstrução de sua própria imagem, desgastada depois de um longo período de censura, repressão e violência, que eram as marcas do regime.

O campo da cultura foi valorizado como canal de comunicação do Estado para com a sociedade civil e da sociedade consigo mesma, alimentado por uma conjuntura de fechamento do espaço público tradicional. E a cultura engajada de esquerda teve um papel central, ainda que contraditório, nesse jogo, no qual práticas de "cooptação" e "resistência" não se excluíram e muitas vezes conviviam nos mesmos agentes e instituições socioculturais. (NAPOLITANO, 2010, p.150)

Napolitano também destaca que não era só o regime militar que via a cultura como uma questão estratégica, a oposição também, mas por razões diferentes. Para a oposição a cultura era um instrumento social de contestação e de resgate de valores democráticos. Já para o regime, a cultura era, simultaneamente, parte da "guerra psicológica da subversão" e parte da mudança dos paradigmas da classe média, que já sofria as consequências da redução do crescimento econômico, que a fez apoiar o Golpe de 1964. O autor também considera que a cultura foi capaz de colocar em um mesmo cenário opositores e colaboradores do regime, visto que esses últimos reconheciam a falta de intelectuais, na direita, capazes de divulgar seus projetos ideológicos. Assim, o regime faz uma leitura racional da "hegemonia cultural da esquerda", que culmina com uma abertura de diálogo com produtores culturais e intelectuais da oposição, de modo a apropriar-se do "nacionalismo cultural" da própria esquerda. (2010, p.149-150)

Jarbas Passarinho, à frente do MEC no governo Médici, dá importantes passos na área cultural ao expandir as atribuições do INL e ao lançar o PAC, que se encarregaria de disponibilizar crédito a determinadas áreas da produção cultural que até então não tinham acesso a benefícios estatais. O PAC retoma a ideia da necessidade da presença do Estado para obter o avanço cultural e tinha como núcleo central a visão de que a cultura seria a formadora da identidade nacional; 
portanto, proteger e preservar as manifestações culturais seriam maneiras de defender a personalidade brasileira e cuidar da segurança nacional.

\begin{abstract}
Embora não tivesse a função explícita de formular uma política oficial de cultura ou encargos de coordenação, a exemplo daqueles conferidos ao Departamento de Assuntos Culturais, o PAC acabou firmando um estilo novo e uma doutrina própria de prática cultural. (MICELI, 1984, p.56)
\end{abstract}

O PAC, mesmo tendo sido concebido emergencialmente e mesmo que não tivesse uma definição clara de sua atuação, ocupou os vazios deixados pelo DAC e cresceu o suficiente para incomodar outras áreas do Ministério, que promoveram seu enfraquecimento, de modo a levar o PAC a perder espaço e poder. Mas foi a atuação do PAC, que priorizava eventos, que fez do MEC empresário de espetáculos, moderno e poderoso, responsável por criar novas vagas de trabalho no mercado cultural. "A área cultural do MEC compunha-se de duas vertentes, a cultural ou 'executiva', representada pelo PAC, e a patrimonial, cujo exemplo mais importante era o Instituto do Patrimônio Histórico e Artístico Nacional - IPHAN." (SILVA, 2001, p.106)

Analisando a primeira metade da década de 1970, podemos observar que ela foi marcada pela apresentação de propostas programáticas mais amplas para a área cultural, mas que apresentaram poucos resultados, diferente do período imediatamente posterior, que é quando acontece a redefinição dos temas mais relevantes para a cultura, “...numa ótica mais operacional e cada vez mais propriamente política e pela renovação institucional, iniciada na Funarte em 1975". (COHN, 1984, p.87)

Em 1974 o Congresso Nacional elege Ernesto Geisel para presidente e assim chega ao fim o período mais duro e opressor do governo militar. Também é neste ano que as questões culturais ganham maior importância. Avançando no projeto iniciado no governo Castelo Branco que instituiu o CFC, o governo Geisel elabora uma política de cultura para guiar as ações do Estado na área cultural.

A gestão de Ney Braga à frente do MEC, no governo Geisel, vai reforçar a estrutura governamental para dar seguimento às diretrizes da política cultural, instituindo o Conselho Nacional de Direito Autoral (CNDA), o CNC e a Funarte, reformulando a Embrafilme e ampliando as atividades do SNT. "Estava lançada a semente do que seria considerado então o embrião de um futuro Ministério da Cultura." (MICELI, 1984, p.70) 
Ney Braga também se destaca pelo fato de ter colocado em prática a PNC, uma reedição atualizada do documento produzido no governo Médici, que logo foi retirado de circulação, chamado "Diretrizes para uma Política Nacional de Cultura".

A PNC seria a "...concretização do reconhecimento oficial da necessidade de incluir a cultura nos planos de desenvolvimento do governo para o país", e mesmo recebendo críticas, ela foi responsável por imprimir avanços no processo de "construção institucional da área cultural", com a criação ou readequação de diversos órgãos e instituições estatais. (SILVA, 2001, p.143, 110)

\begin{abstract}
A importância político-institucional desse "ideário de uma conduta" consistiu, sobretudo, no fato de haver logrado inserir o domínio da cultura entre as metas da política de desenvolvimento social do governo Geisel. (MICELI, 1984, p.57)
\end{abstract}

Assim, a PNC pode ser considerada um marco no processo de conciliar a cultura ao regime político vigente e também de procurar extinguir e neutralizar a produção das forças adversárias, de modo que o governo pudesse ter o controle do processo cultural.

\begin{abstract}
A censura e a intervenção nas instituições culturais têm a ver com essa face mais visível, apesar de tudo, de uma ação que, no entanto visava mais fundo. A busca de uma política nacional de cultura realmente existe nessa fase crucial dos anos 1970, e seu objetivo era bem definido: a codificação do controle sobre o processo cultural. Tudo isso tem a ver, sem dúvida, com a posição de desvantagem em que o regime se encontrava nesse terreno, visto que as posições mais importantes ainda estavam ocupadas pelos "adversários". (COHN, 1984, p.88)
\end{abstract}

A comparação, entre o texto da PNC apresentado em 1973 no governo Médici e o apresentado em 1975 na gestão de Ney Braga, indica que este último seguia praticamente a mesma linha doutrinária do documento de 1973, podendo quase ser considerado como uma reedição da PNC elaborada no governo Médici. Mas era nos pequenos detalhes que as diferenças se mostravam.

Cohn chama a atenção para o fato de que o documento de 1973 indicava a necessidade de se criar um novo organismo para se ocupar da área cultural, ou mesmo adaptar algum órgão já existente, ampliando sua área de competência e sua autonomia político-administrativa, indicando a opção de se criar um ministério específico para a cultura. O autor, inclusive, avalia que essa ideia tenha criado algum tipo de conflito dentro do próprio MEC e por isso o governo Médici tenha decidido recuar e tirar o plano de circulação pouco depois de o mesmo ser divulgado. 
Já em 1975, o MEC é indicado para coordenar a ação do Estado no campo da cultura, através do CFC e do DAC. (1984, p.88)

\begin{abstract}
A reorganização institucional do $\mathrm{MEC}$, promovida para viabilizar a PNC, abriu espaço para que os gestores do PAC, principais articuladores da proposta de institucionalização do programa, defendessem a criação de um novo órgão, com o argumento de que a política cultural aprovada necessitaria de uma instituição que viabilizasse a sua implementação. (SILVA, 2001, p.111)
\end{abstract}

A PNC de 1975 tinha uma visão mais ampla sobre cultura; considerava que ela seria a "...somatória das criações do homem no prosseguimento da obra da própria criação" e que "...todos participam todo tempo". A concepção da participação universal, sem distinção, na formação da cultura, remetia à ideia de justiça social, ou seja, que todos pudessem e fossem "ensinados" a usufruir dos benefícios da cultura, pois não se poderia mais aceitar que ela fosse apenas um privilégio e um patrimônio das elites. $O$ documento indicava que a participação universal na formação da cultura não deveria ser vista como um problema, ao contrário do acesso diferenciado aos resultados, que demandava uma intervenção do Estado na esfera do "cidadão comum". (COHN, 1984, p.89)

Ainda segundo o autor:

É difícil não suspeitar que o componente antielitista desse passo da
argumentação tenha pelo menos tanto a ver com a ideia de que boa
parte das "elites" se identificaria com os segmentos sociais adversos
ao regime do que com quaisquer outros impulsos democratizadores
da cultura. A ênfase no caráter espontâneo do processo cultural e
nas suas fontes genericamente populares, expressa na preocupação
pelo cidadão comum, tem aí a função de tornar dispensáveis as
elites indesejáveis, mas abre o flanco às objeções liberais quanto à
própria necessidade da presença estatal na área cultural. (COHN,
1984, p.89)

O ponto central da argumentação, apresentada no documento, é ver a cultura como capaz de contribuir para a construção e a descoberta da personalidade nacional, portanto, defendê-la significaria o mesmo que defender o território nacional. A PNC também afirmava que não bastava proteger o patrimônio cultural já existente, mas agir no sentido de que ele fosse aumentado, expandindo assim a presença e a influência da cultura brasileira no âmbito internacional e ampliando sua capacidade de receber e assimilar influências de outras culturas. Portanto, o foco era garantir a formação de um caráter nacional forte e influente. Qualquer ação contrária a essa ideia era entendida como um risco à preservação da personalidade brasileira e para 
a segurança nacional.

Dessa forma, "a intensificação das atividades culturais está chamada a representar uma das ações fundamentais" naquilo que realmente interessa, que é a "estratégia de desenvolvimento, que comove a alma brasileira e mobiliza a potencialidade nacional". Em consequência, a política cultural, concebida na sua interpenetração com as "políticas de segurança e desenvolvimento", tem por significado "a presença do Estado, como elemento de apoio e estímulo - que não se confundirá com coerção ou tutela, na integração do desenvolvimento cultural dentro do processo global do desenvolvimento brasileiro". (COHN, 1984, p.90)

Cohn observa que o destaque do documento fica por conta das medidas nele apresentadas, voltadas à realização dos projetos que favorecessem 0 desenvolvimento da cultura brasileira. Seriam elas: a criação de serviços nacionais de música, artes plásticas e folclore, de um fundo nacional de desenvolvimento da cultura e a transformação de casas da cultura em centros de influência regional; a colaboração com universidades; o cuidado com monumentos particulares tombados e o financiamento de projetos de natureza cultural. (1984, p.91) Em síntese, a PNC estabelece o conjunto de diretrizes a serem observadas pelo Governo Federal, que seriam a preservação do patrimônio, o incentivo à criatividade e a difusão das criações e manifestações culturais.

\begin{abstract}
A importância político-institucional desse "ideário de uma conduta" consistiu, sobretudo, no fato de haver logrado inserir o domínio da cultura entre as metas da política de desenvolvimentosocial do governo Geisel. Foi a única vez na história republicana que o governo formalizou um conjunto de diretrizes para orientar suas atividades na área cultural, prevendo ainda modalidades de colaboração entre os órgãos federais e de outros ministérios, como, por exemplo, o Arquivo Nacional do Ministério da Justiça e o Departamento Cultural do Ministério das Relações Exteriores, com secretarias estaduais e municipais de cultura, universidades, fundações culturais e instituições privadas. (MICELI, 1984, p.57)
\end{abstract}

A PNC de 1975, embora tenha muitas semelhanças doutrinárias com a de 1973, como já dissemos, se distingue pela sua forma de apresentá-las, pois abandona o argumento da segurança e do fortalecimento do país e introduz a ideia de que o desenvolvimento do Brasil não deveria ser apenas econômico, mas principalmente social, e a cultura teria um papel importante para alcançá-lo. O texto é mais direcionado aos tecnocratas encarregados de conduzir o processo de desenvolvimento pretendido e assume um viés mais humanista, isto é, discute uma política de cultura voltada a obter a completa realização do homem brasileiro como 
pessoa, sua plenitude no meio em que vive, e não só comprometida com o acúmulo de conhecimento.

O argumento humanista baseava-se em manter preservada a originalidade e a identidade da cultura, firmada nos verdadeiros valores históricos, sociais e espirituais que são característicos do homem brasileiro, porém, esse argumento vinha acompanhado de um viés instrumental, pois afirmava que a continuidade cultural seria a base da sobrevivência de uma nação, portanto, a cultura seria então um meio indispensável para fortalecer e consolidar a nacionalidade. (COHN, 1984, p.92)

A partir da afirmação de que "uma política de cultura deve levar em conta a ética do humanismo e o respeito à espontaneidade da criação popular", a PNC defendia a ideia de que uma política cultural seria a composição de diferentes ações de governo, concebidas para despertar a criatividade, ameaçada pelo domínio dos meios de comunicação de massa e pela racionalidade da sociedade industrial. Promover e incentivar a participação no processo cultural, fomentar a produção e a ampliação do consumo seriam alguns dos objetivos que deveriam constar de qualquer política cultural.

Gabriel Cohn (1984, p.93) observa que a combinação de "respeito" à diversidade e à liberdade de criação com "intervenção" levava a uma contradição, pois propunha uma ação "antiestatizante" feita por um órgão estatal. O autor entende que os objetivos declarados tinham um forte componente imobilizador, qual seja, o de que a condição primordial para atingi-los seria a de se descobrir o "âmago do homem brasileiro" e o estilo de sua vida, ou seja, conhecer a essência da cultura brasileira.

O artista plástico e designer Aloísio Barbosa Magalhães (1927-1982) ${ }^{37}$ vai, mais à frente, resolver um dilema que o documento não conseguira desvendar, indicando a importância em se adotar uma postura mais dinâmica, propositiva e aberta às mudanças culturais da sociedade, principalmente pela própria característica do Brasil, um país estratificado culturalmente, ou seja, uma política cultural que absorvesse e também contemplasse as nossas diferenças culturais.

\footnotetext{
${ }^{37}$ Pintor, designer, gravador, cenógrafo e figurinista. Formado em Direito pela Univ. Federal de Pernambuco. Considerado um dos mais importantes designers gráficos brasileiro do século $X X$ e um dos pioneiros na introdução do design moderno no Brasil. Ajudou na criação da primeira escola superior de design neste país, a Escola Superior de Desenho Industrial do Rio de Janeiro (ESDI). Em 1975 implanta o CNRC. Em 1979 assume a direção do IPHAN, onde promove uma mudança profunda na visão da Instituição, a partir de seus conceitos amplos sobre bens culturais e suas propostas para preservação da memória nacional. Disponível em $<\mathrm{http}$ ://www.itaucultural.org.br/aplicExternas/enciclopedia_IC/index.cfm?fuseaction=artistas_biografia\&cd_verbete= 543\&cd_idioma=28555>. Acesso em 20/nov/2012.
} 
Trata-se da atuação desenvolvida sob a direção de Aloísio Magalhães nos anos seguintes, no Patrimônio Histórico e Artístico Nacional e na Fundação Pró-Memória, que consistiu em se repensar a questão da "memória nacional" para além das concepções acumulativas e estáticas antes vigentes também nos documentos oficiais. A nova concepção busca ser dinâmica, aberta ao processo histórico da sociedade brasileira. (COHN, 1994, p.94)

Mas é importante frisar que mesmo essas contradições não impediram que resultados importantes fossem obtidos na área cultural. A criação da Funarte, em 1975, que seguia os termos da PNC, foi apresentada como sendo um instrumento do governo para ajudar a sociedade brasileira a manifestar suas habilidades artísticas. Um outro exemplo foi o lançamento, no mesmo ano, do CNRC, que vai contribuir para se repensar o processo de intervenção cultural. Concebido fora das estruturas estatais, o CNRC não se alinhava a nenhum plano ou programa cultural mais importante e, curiosamente, recebeu apoio do MIC e não do MEC, o que seria mais lógico do ponto de vista da temática que iria tratar.

Essa opção encontra explicação no fato de que havia o entendimento de que qualquer ação de preservação de patrimônio cultural dependeria de recursos e de regulação vindos do Governo Federal e que o MEC ainda tinha uma estrutura conservadora e obediente ao controle "político-ideológico do regime". (FALCÃO, 1984, p.32)

\begin{abstract}
O Ministro Severo Gomes se mostrara sensível ao projeto de designer e artista plástico Aloísio Magalhães de mapear e qualificar os "indicadores culturais brasileiros" em condições de imprimir feições "autênticas" aos produtos industriais brasileiros. Para tanto, bastava de início financiar a contratação de uma equipe de pesquisadores empenhados numa espécie de levantamento arqueológico multidisciplinar, visando o resgate dos traços e raízes culturais a serem utilizados como matéria-prima de um desenho caracteristicamente 'nacional' dos produtos industriais. (MICELI, 1984, p.79)
\end{abstract}

Justamente essa configuração institucional paralela foi o que permitiu que o CNRC desse prosseguimento a suas atividades, mesmo depois do fim do governo Geisel. A autonomia dos técnicos, mesmo que frágil, para definir programas, controlar seus recursos financeiros e contratar pessoal qualificado, garantiu a execução de programas que alcançavam os mais diferentes espectros ideológicos e disciplinares. O CNRC é então incorporado pelo IPHAN no governo de João Figueiredo, que dava continuidade no processo de abertura política e que por isso buscava criar espaços institucionais no Poder Executivo para a elaboração de novas políticas públicas.

É importante compreender que a PNC preconizava que o objetivo final de uma 
política cultural seria o de possibilitar ao homem brasileiro alcançar sua plenitude, sua realização como pessoa, sendo assim, haveria de acontecer “...'melhorias' dos indivíduos como agente do processo de desenvolvimento". Sendo o homem brasileiro a preocupação central da PNC, então a política cultural deveria se ocupar da cultura brasileira, e não de uma cultura em um sentido abstrato, uma discussão já vista no governo Vargas. (SILVA, 2001, p.118)

A PNC reconhecia ainda a existência de diferenças regionais na formação da cultura brasileira, dando a ela duas dimensões, a regional e a nacional, que precisavam ser contempladas na formulação dessa política cultural, que deveria também propor medidas de preservação de manifestações culturais específicas, incentivar ações que permitissem o intercâmbio cultural entre elas e, principalmente, apoiar a produção cultural, de modo a estimular o processo de criação.

O documento expressa uma dupla preocupação: promover, por um lado, a continuidade das manifestações culturais tidas como caracteristicamente brasileiras, ou seja, a preservação do que é considerado patrimônio cultural da nação e, por isso mesmo, alicerce da identidade nacional, e, por outro, as mudanças impostas pelo desenvolvimento, tanto interno quanto externo, através do incentivo à criatividade e à inovação no campo da produção cultural. (SILVA, 2001, p.119)

Para o regime, a cultura seria uma forte aliada para que o país atingisse o desenvolvimento esperado, desta forma, a cultura deveria ser acessível a todos e seus agentes promotores (o povo brasileiro) necessitavam ser qualificados. $O$ documento da PNC considerava fundamental a adoção de valores, comportamentos mais alinhados aos novos padrões sociais que se pretendia atingir.

[...] um dos objetivos declarados pelos condutores do regime era o saneamento moral e ético da sociedade, que deveria ocorrer através de um aperfeiçoamento das instituições políticas e sociais brasileiras. Nesse sentido, tanto nas justificativas para as medidas que visavam o controle das instituições políticas quanto nas propagandas oficiais que buscavam fortalecer instituições sociais como família, encontramos a recorrente alusão a valores considerados característicos da nação brasileira ou necessários ao desenvolvimento integral do país. Os princípios culturais aos quais se referem os formuladores da PNC são, certamente, esses valores. (SILVA, 2001, p.125)

O regime, ao considerar o acesso aos resultados da cultura como um direito, assume que a cultura seria parte integrante do bem comum e, portanto, a política cultural não era destinada a poucos privilegiados. 
Silva identifica que seriam dois os pressupostos assumidos pela PNC: a) não intervir na atividade cultural espontânea e nem conduzir a produção segundo orientação ideológica que limitasse a liberdade de criação; e b) dar as diretrizes para que o governo pudesse fomentar e apoiar ações culturais individuais ou de grupos. (2001, p.210)

Importante ressaltar que o documento que apresentava a PNC indicava que a política cultural seria a arte de definir os objetivos comuns nacionais a partir de compreensão de tais desejos, mesmo entendimento da ESG. Interesses nacionais, aspirações nacionais e objetivos nacionais eram expressões para designar as aspirações mais gerais que guiam as nações rumo à sua evolução.

Os objetivos nacionais seriam resultado de uma interação equilibrada entre elite dirigente e povo, interação esta baseada na análise dos interesses do povo, que poderiam ser observados através de seu comportamento histórico e de suas tendências e ideais. Numa leitura mais atualizada da formulação da ESG, esses objetivos seriam divididos em dois tipos: Permanentes, "interesses e aspirações vitais e que, por isto mesmo, subsistem por longo tempo"; e Atuais, "etapas intermediárias com vistas a alcançar ou manter os Objetivos Nacionais Permanentes". (SILVA, 2001, p.122)

A política de cultura tinha o foco no aspecto dinâmico da criação, desta forma sua atuação também deveria ser dinâmica e estar situada entre o presente, uma dimensão real, e o futuro, uma dimensão ideal, ou ainda, levar em consideração o presente, entendido como uma continuação do passado, para projetar o futuro, indica uma visão evolutiva do processo cultural.

A PNC deveria então: a) Generalizar o acesso cultura, incentivando a participação nos seus resultados, tanto dos que a produzem, quanto daqueles que a consomem; b) Garantir a espontaneidade da criação, por meio do incentivo do Estado à criação e do oferecimento de condições para a realização do trabalho; e c) Proteger a qualidade da criação cultural e de quem as produz e combater o "culto à novidade", estimulado pelos meios de comunicação de massa, prejudicial à qualidade dos resultados.

A cultura brasileira, segundo o documento, seria a reunião das mais diferentes manifestações culturais de grupos humanos de origens diversas, que dá a ela um caráter nacional, mas com características regionais. Assim, a cultura brasileira teria a capacidade de acolher, de assimilar, de refundir e de reelaborar as manifestações culturais, conferindo-lhe uma marca própria. A cultura brasileira seria a expressão da 
personalidade do povo que a criou, personalidade resultante do encontro do índio, do branco e do negro.

Pode-se notar que o regime militar retoma, nas definições de cultura e de identidade brasileiras adotadas, concepções do Estado Novo, uma visão nacionalista, influenciada pelas obras de pensadores como Gilberto Freyre, que se refletiu também no campo educacional e na política de preservação de patrimônio artístico, histórico e nacional. Havia também o cuidado, por parte do Estado, de demonstrar que as suas ações atendiam exigências da própria Constituição, ou seja, o governo procurava sempre justificar, numa permanente busca pela legitimidade de suas ações, que as medidas por ele adotadas no campo cultural eram fundamentadas em bases legais $^{38}$.

Resumidamente, as diretrizes da PNC seriam: a) Respeitar as diferenciações regionais; b) Proteger e valorizar o patrimônio histórico e artístico das manifestações folclóricas e das artes populares; c) Respeitar a liberdade de expressão; d) Estimular a criação das "expressões do espírito" do homem brasileiro, para difundir esses valores nos meios de comunicação de massa; e) Apoiar a formação de profissionais; f) Incentivar os instrumentos materiais de modo a ampliar a criação e a difusão das mais diferentes manifestações culturais; g) Ampliar a aproximação da cultura brasileira de outras culturas, permitindo que esses novos grupos participem da cultura brasileira; e h) Disseminar a ideia de que o desenvolvimento nacional não se limita ao desenvolvimento econômico, mas inclui o desenvolvimento sociocultural que contribui para aumentar o nível de vida. (SILVA, 2001, p.128-129)

Essas diretrizes se incluem nos seus cinco objetivos básicos: conhecimento, preservação dos bens de valor cultural, incentivo à criatividade, difusão das criações manifestações culturais e integração. Também são elencados os elementos para a ação, chamados de componentes básicos. Além das orientações sobre o incentivo às manifestações culturais regionais, a PNC esclarecia que o apoio deveria ser também estendido à criação e não apenas ao produto final. Assim, contemplava-se a literatura através do reforço ao mercado editorial e à defesa dos direitos do autor; o patrimônio histórico e científico pela conservação de símbolos culturais da História do Brasil; o teatro pelo incentivo à produção, circulação e consumo; a cinematografia nacional dando-Ihe base artística e tornando a produção mais competitiva; a produção

\footnotetext{
${ }^{38}$ Segundo Silva, as bases legais que fundamentavam a política governamental de cultura seriam: Constituição Federal de 1969, Artigo 180, parágrafo único que diz: "O amparo à cultura é dever do Estado"; Decreto-lei n. 200/1967, Artigo 39, que inclui a cultura, as letras, as artes e o patrimônio na área de competência do MEC e o Decreto-lei n. 74/1966, que cria o CFC e define como uma de suas atribuições a formulação da PNC. (2001, p.128)
} 
musical, também protegendo os direitos do autor e a difusão da produção; a dança pela preservação dos símbolos gestuais; as artes plásticas com o aumento da pesquisa através dos laboratórios de criatividade e, por fim, a cultura pela sua difusão através dos meios de comunicação.

Os meios adequados para se colocar em prática esses componentes básicos seriam o fomento à pesquisa, a realização de festivais de artes, a valorização de museus, o desenvolvimento de campanhas de informação e educação, a criação de cursos de extensão, o oferecimento de bolsas de estudos, a cooperação entre Instituições governamentais e universidades (inclusive a promoção de cursos de formação profissional universitária especializada para cinema, teatro), entre outros.

Havia um claro entrelaçamento entre a política de cultura, de segurança nacional e de desenvolvimento, uma versão "grosseira do instrumentalismo", nas palavras de Cohn. (1984, p.94) A PNC vai, assim, atender aos interesses do governo, que via na cultura uma forma de obter a legitimação do regime e, portanto, defender "determinados" valores garantidores da coesão social e do esforço comum para um mesmo objetivo era uma questão de segurança nacional. Buscava-se a internalização de valores e comportamentos importantes para a "democracia", que os militares diziam conduzir, e a coesão social, fundamental para o processo de distensão que se iniciava.

O lado pedagógico que o regime imprimia em suas ações podia ser visto também na propaganda oficial, que transmitia mensagens motivacionais, conclamando o povo e a juventude a amarem a Pátria, a confiarem no governo e a participarem do esforço para levar o Brasil ao desenvolvimento.

No governo Geisel a área cultural do MEC viveu um período de muita agitação e mudanças. Geisel procurava assim cumprir a missão pactuada pelos militares de reorganizar e modernizar o país, e por isso mesmo desenvolver políticas para cada área de governo era uma condição essencial para se atingir esses objetivos. Seria correto afirmar que a Doutrina da ESG tenha influenciado a estratégia de investir em cultura, já que ela influenciava também as principais ações do governo.

\footnotetext{
Desta forma, podemos supor que o investimento do Estado na área cultural, norteado por uma política específica para o setor, tenha sido visto, naquele momento em especial, como uma fórmula que garantiria resultados mais eficazes e duradouros do que a repressão na busca da almejada reorganização da sociedade. (SILVA, 2001, p.146)
}

Ainda Silva: 
Procurava-se o reconhecimento e a adesão aos valores exaltados pelo regime e, consequentemente, a transformação, sem rupturas, de comportamentos e visões de mundo da maior parte do "povo" brasileiro. Uma transformação desse tipo evitaria riscos, uma vez suspensa a repressão, de uma volta ao passado imediatamente anterior ao golpe. (2001, p.146)

Novamente, a exemplo do governo Vargas, vemos um Estado que, ao mesmo tempo em que censurava e reprimia manifestações que fossem contrárias aos interesses do regime ou que ele julgava serem prejudiciais à imagem do país, também incentivava e promovia manifestações artísticas sui generis, que representavam nossos traços culturais, e as utilizava como símbolos do caráter criativo e talentoso do povo brasileiro. Oliven observa que o que era considerado pelo Estado subversivo nos anos 1960 e 1970, agora era visto como um “...espaço para a construção de um projeto de hegemonia"39 ${ }^{\text {. }}(1984$, p.51)

Mesmo sendo o desenvolvimento e a segurança as principais preocupações do regime, ele nunca deixou de lado a educação e a cultura, pois elas eram elementos importantes na construção de um consenso em torno dos interesses do governo e de uma nova visão de mundo que servisse aos seus interesses e legitimasse suas ações. Buscava-se um consenso de valores culturais, ou de visões de mundo, que determinassem as ações da sociedade, no momento em que o governo militar dava início ao processo de distensão, mas sem abrir mão do controle social. Havia, portanto, sim, um objetivo hegemônico na área cultural.

A propaganda oficial e a política cultural do governo Geisel souberam "vender" bem a ideia de que o Brasil era um país singular, fruto de uma combinação de diferentes influências. Aliás, é bom lembrar que não foi apenas o governo militar o primeiro a fazer uso desse expediente, pois antes muitos intelectuais já buscavam em seus trabalhos criar um sentimento nacional, que estruturasse a identidade brasileira e lançasse um olhar otimista ao Brasil ${ }^{40}$.

\footnotetext{
39 Segundo Bobbio, na linguagem gramsciana, o termo hegemonia aparece em dois escritos de Gramsci, de 1926 (Carta ao Comitê Central do Partido Socialista Soviético e Alguns temas da questão meridional, este inacabado), se referindo à "aliança entre operários e camponeses, no sentido de 'direção política'”, sentido que mais à frente é ampliado. Nos Cadernos, Gramsci traz a ideia de 'direção cultural' (reforma intelectual e moral), que incluiria a 'direção política' (formação da vontade coletiva) e a completaria. A função da hegemonia não seria a de apenas formar uma vontade coletiva capaz de "criar um novo aparelho estatal e de transformar a sociedade", mas também a função de elaborar, difundir e concretizar uma nova concepção de mundo. (1994, p.48)

${ }^{40}$ Chauí indica que: nos anos 1920, o slogan era Consolidar a Nação (o que legitimou o extermínio dos rebeldes de Canudos e do Contestado); nos anos 1920-1930, Construir a Nação (o que permitiu a absorção de todas as manifestações culturais pelo Estado); nos anos 1940-1950, Desenvolver a Nação (fazendo com que a cultura popular fosse considerada atraso, ignorância e folclore); no início dos anos 1960, Conscientizar a Nação (levando o populismo a produzir a imagem dupla da Cultura Popular como boa-em-si e alienada-em-si, precisando da condução de vanguardas tutelares e revolucionárias); durante os anos 1960-1970, Proteger e Integrar a Nação (o que levou às práticas "modernas" de controle estatal da Cultura Popular) e nos anos 1990, Conciliar a Nação. (1999, p.99-100)
} 
Esse desejo de controlar a cultura popular não é novo. Pode ser visto durante os anos 1930 e 1940, no Estado Novo, como vários estudos já mostraram, e também na ideologia do Brasil-Potência ou da "integração nacional", da ditadura dos anos 1970, que incorporou duas atividades muito populares, dando-lhes cunho nacionalista para a glorificação do Estado: o carnaval e o futebol.

No carnaval financiava escolas de samba (mas submetia suas músicas e danças à aprovação da Censura Federal), que serviam, ao mesmo tempo, ao incremento do turismo e à celebração do regime e no futebol, criava um sentimento patriótico que percorria o país durante os campeonatos mundiais que aconteceram no período do "milagre brasileiro", com transmissões radiofônicas e televisivas que criavam a imagem da "nação em luta" usando linguagem belicosa e militar na descrição dos jogos. E os treinadores oficiais eram militares. O regime também encomendava músicas com letras patrióticas - a mais famosa delas Noventa milhões em ação/ Pra frente Brasil. (CHAUÍ, 1999, p.90-91)

A princípio apostava-se na seriedade do brasileiro e no pensamento de que se houvessem líderes, a civilização chegaria por nossas terras, proposta simbolizada pelo viés da "ordem e progresso", identificado na pessoa de Duque de Caxias, ou na imagem do povo ordeiro, representada na mensagem "este é um país que vai para frente". "Esta visão perpassa nossa história recente e é apresentada, constantemente, por uma parte de nossas classes dominantes e das classes intelectuais a seu serviço, como a verdadeira imagem do Brasil". Outra aposta seria a de apontar a existência de um ethos brasileiro, intraduzível, como a palavra saudade, incompreensível para os estrangeiros, que também não conseguem entender o "jeitinho" brasileiro, a malandragem, a malícia. É de se notar que nas duas apostas de construção de identidade se dá a conotação de nacionalidade e/ou raça, e menos de classe, ou como dizia Oswald de Andrade: no Brasil, diferente da Europa, o contrário do burguês seria o boêmio, não o proletário. (OLIVEN, 1984, p.46-47)

O pensamento da nossa intelectualidade tem oscilado no que diz respeito a estas questões. Assim, em certos momentos nossa cultura é profundamente desvalorizada por nossas elites, tomando-se em seu lugar a cultura europeia (ou mais recentemente a norte- americana) como modelo. Como reação, em outros momentos nota-se que certas manifestações da cultura brasileira passam a ser profundamente valorizadas, exaltando-se símbolos como Macunaíma, a figura do malandro, o carnaval, o samba, o futebol. (OLIVEN, 1984, p.43)

Em certos momentos a cultura brasileira foi vista como uma apropriação e releitura, 
por parte da elite, de traços culturais concebidos nas metrópoles e os únicos dignos a serem adotados por ela. Em outros momentos, valorizava-se o que era genuinamente brasileiro, as raízes nacionais, ou seja, o índio, a vida rural. O caráter nacional também era visto de maneiras distintas. Enquanto os autores românticos exaltavam as virtudes do caráter brasileiro, intelectuais, que buscavam explicar a sociedade pela mistura de raças, tinham uma opinião pessimista e preconceituosa sobre o brasileiro, vendo-o como um ser indolente.

\begin{abstract}
Assim, é o Estado, finalmente, que define o nacional-popular. Não é casual, portanto, que no Brasil as ideias de consolidação nacional, construção, preservação, proteção, desenvolvimento, modernização, integração e conciliação nacionais tenham-se constituído em políticas culturais do Estado e para o Estado. (CHAUÍ, 1999, p.106)
\end{abstract}

$\mathrm{Na}$ verdade, muitos mitos foram sendo incorporados pela sociedade brasileira como um todo, mitos que embora não se efetivem na nossa prática diária, são incontestáveis como representação, pois são mitos, por exemplo: o Brasil como "dom da Natureza" e "presente de Deus" à humanidade (apesar das secas nordestinas); como povo pacífico, ordeiro e não-violento (apesar do genocídio da população indígena, da escravidão da população negra); como o país da democracia racial (apesar da discriminação visível e invisível); como país de um povo alegre e sensual (apesar do machismo, da discriminação sexual); como "país dos contrastes. (CHAUÍ, 1999, p.97-98)

\footnotetext{
A essa mitologia veio incorporar-se, a partir dos anos 1950, a do desenvolvimentismo, a mudança da ordem dentro da ordem... [...] Dessa maneira, o "bom selvagem" - definindo a alma brasileira - e o "progresso industrial" - definindo o trabalho das "forças vivas da Nação", como dizem os discursos oficiais - oferecem à sociedade uma mitologia bifronte, que conserva o passado bondoso e paternalista e promete um futuro de grandezas sem igual. A mitologia captura a temporalidade, elaborando uma história sem rupturas. (CHAUÍ, 1999, p.96-97)
}

Oliven (1984, p.44) considera que a escolha do tipo social que represente nossa nacionalidade está ligada ao fato de se decidir quais seriam os produtores válidos da cultura brasileira e também o que seria considerado como cultura. O autor destaca que a cultura pode ser vista sob duas perspectivas, a que considera cultura as manifestações intelectuais e artísticas da elite, e outra, carregada de saudosismo e de sentimento ufanista, que considera as manifestações culturais das classes dominadas como raízes de nossa nacionalidade. 
Marilena Chauí (1999, p.94-95) destaca que a busca da identidade nacional, o caráter nacional, sempre foi um fantasma que rondava as classes dominantes e a intelectualidade brasileira desde meados do século XIX. Fomos ensinados desde crianças a relacionar os símbolos da bandeira nacional (cores, imagens, formas, etc.) à riqueza, natureza, nosso espírito de paz e de ordem e progresso. Verde e amarelo são cores nacionais. Aprendemos que somos um povo especial, pois fomos formados pela união de três raças, que nossa terra é fértil e cordial.

A autora considera que essa mitologia foi sendo construída ao longo do tempo pela classe dominante brasileira para "...servir-lhe de suporte e de autoimagem celebrativa, enfatizando o lado 'bom selvagem tropical' que constituiria o caráter nacional brasileiro na perspectiva das oligarquias agrárias, embevecidas com o mito brasileiro cordial, ordeiro e pacífico". (CHAUÍ, 1999, p.96)

Mais uma vez torna-se necessário esclarecer que não julgamos que o
regime militar, e o governo Geisel em particular, tenha simplesmente
tentado manipular, astuciosamente, as representações pré-existentes
sobre o país, o povo e a cultura acima mencionadas. Supomos, na
verdade, que estas imagens sobre o Brasil já estivessem incorporadas
na cosmovisão militar, fazendo parte, portanto, da visão de mundo
compartilhada pelos oficiais das Forças Armadas. Supomos, também,
que a ESG tenha desempenhado papel marcante, se bem que não
exclusivo, na difusão de tais imagens no meio militar. (SILVA, 2001,
p.152-153)

É fato que muitas das manifestações culturais das "classes dominadas" vistas, a princípio, com preconceito, acabam por serem apropriadas pelas classes dominantes, que manipulam seus significados e as transformam em símbolos nacionais, como o samba, a feijoada. Essa apropriação e a transformação das manifestações populares em símbolos de identidade nacional ocorrem em períodos de grande transformação social, econômica e política, ou seja, quando o mercado nacional se firmava e o país se industrializava. A partir de 1964 aumenta a entrada do capital estrangeiro no Brasil; a indústria nacional (incluindo a cultural) amplia sua produção de bens de consumo.

A televisão passa a produzir seus próprios programas, que retratam situações típicas do Brasil, se apropriando de temas e reelaborando-os, dando a eles uma mensagem ideológica de fácil assimilação. Assume, então, como outros veículos de comunicação, um caráter pedagógico de unificação, pela imposição da cultura dominante, bastante útil ao mercado, e de reforço de uma autoimagem - brasileiro cordial, ordeiro e pacífico - interessante ao regime. Segundo Chauí (1999, p.28): 


\begin{abstract}
1) no Brasil, sociedade autoritária, os meios de Comunicação de Massa são uma concessão estatal a empresas privadas, ficando sob o controle ideológico e político do Estado e, frequentemente, são instrumentos do Estado para fins de propaganda e de doutrinação. 2) embora de difícil definição, a expressão Cultura Popular tem a vantagem de assinalar aquilo que a ideologia dominante tem por finalidade ocultar, isto é, a existência de divisões sociais, pois referirse a uma prática cultural como popular significa admitir a existência de algo não-popular, que permite distinguir formas de manifestação cultural numa mesma sociedade. A noção de massa, ao contrário, tende a ocultar diferenças sociais, conflitos e contradições.
\end{abstract}

Segundo Oliven (1984, p.51), no início dos anos 1960, o regionalismo pautava as discussões sobre nacionalidade. O Estado e os meios de comunicação transformaram essa discussão em algo insignificante, ao criar programas que procuravam valorizar "aquilo que é nosso", que misturavam assuntos como as roupas utilizadas na Folia de Reis, com as músicas de Roberto Carlos, mostrando o Brasil como uma "...soma colorida e tropical de manifestações regionais (apresentadas de um modo museológico e tendendo para o exótico e turístico)", que deveriam ser conhecidas, respeitadas e divulgadas nas grandes cidades do país. Ainda segundo o autor, o “...Estado avoca para si o papel de manter acesa a chama da memória nacional e, por conseguinte, se transforma no criador e bastião da identidade nacional".

Do que foi discutido até aqui podemos perceber a complexidade da relação do Estado com a cultura. De agente censor a promotor da produção cultural, o Estado assume a tarefa de criar uma "imagem integrada" do Brasil, se valendo do monopólio da memória nacional. O Estado assume a tarefa de manter viva a memória nacional e se transforma em sustentáculo da identidade nacional, a despeito da crescente internacionalização da economia. (OLIVEN, 1984, p.51)

É nisto que consiste a tentativa de substituir um modelo fundamentalmente baseado na coerção, por um modelo ancorado na hegemonia e na manipulação dos símbolos nacionais. A contradição do modelo consistia no fato de o projeto de hegemonia estar separado do aspecto socioeconômico, ou seja, o Estado imprimia grande importância à cultura, mas não pretendia mudar as "regras da ordem econômica e política". Oliven ressalta:

Assim, através de uma abertura restrita, do afrouxamento da censura e de uma reforma partidária que visa a reordenação do poder pelo alto se pretende soldar a sociedade sem modificar substancialmente questões-chave como a legislação trabalhista, a distribuição de renda, a posse da terra, etc. $O$ projeto obviamente é tão precário que o próprio crescimento da inflação coloca em questão a sua validade. 
$(1984$, p.51-52)

Contradições à parte, o regime se mantinha presente na área cultural, incentivando a atividade artística, chegando a ser considerado por alguns como o "grande mecenas da cultura brasileira nos anos 1970". A maior intervenção do Estado concentrava-se nas atividades culturais que apresentavam grandes dificuldades de se manter por não atenderem às exigências do mercado, dando assim uma marca "conservacionista" nas políticas culturais oficiais.

Segundo Raymond Williams (2000, p.43), o "patronato" público, como ele define o estímulo ou intervenção do Estado no interior do mercado ou fora de seu âmbito, com recursos oriundos de tributação, apresenta algumas definições bastante novas de função, tais como a manutenção e expansão deliberada das artes como uma questão de política pública geral. O autor também considera que a característica que define as relações sociais de patronato é a condição privilegiada do patrono, que pode ou não dar seu apoio ou encomendar ou não uma obra.

As relações sociais específicas desse privilégio provêm, naturalmente, da ordem social como um todo; ali é que os poderes e os recursos do patrono estão arrolados ou protegidos; nos termos mais crus, ele está fazendo o que quer com o que the pertence. (WILLIAMS, 2000, p.43)

No caso do Estado, o apoio advém de dinheiro público, ou seja, não se trata de 'fazer o que quiser com o que é seu', mas ainda assim consideramos como patronato a intervenção e estímulo do Estado área cultural. Nesse caso, na liberação de verba, e, principalmente, a sua condição de definir políticas públicas voltadas à cultura que também, em última instância, vão decidir como e onde o dinheiro será aplicado, caracteriza a condição privilegiada de patrono que o Estado possui. Interessante salientar aqui a opinião de Machado $(1984$, p.9) sobre a existência ou não de política cultural no país naquele período. O autor entendia que existiam várias "políticas culturais', na medida em que diferentes órgãos, que não tinham relação entre eles, implementavam políticas públicas. Não havia, portanto, um comando central, que definisse metas e mensurasse os resultados, condição para a existência de uma política pública do Estado.

No caso da cultura, o que se via é que nem todos os órgãos que atuavam na área estavam subordinados ao MEC, sem contar que também estados e municípios tinham suas próprias políticas, mantidas com orçamentos próprios. Para complicar mais a situação, não havia uma clara definição do limite de intervenção do Estado na área 
cultural, e uma "ideologia, democraticamente aceitável", que pudesse legitimar e orientar essas ações, o que causava embates entre opiniões contraditórias, paralisia das decisões e uma tendência a favorecer pequenos projetos, que pouco ajudavam no desenvolvimento cultural. Ainda segundo Machado:

É preciso destacar, ainda, que a ausência de uma política cultural
definida por parte do Estado, e de uma estrutura organizacional
hierárquica, gerou uma autonomia bastante ampla para essas
agências, autonomia que foi ainda mais acentuada pelo fato de alguns
setores da sociedade as terem adequadamente percebido como
"agências de socialização política" ou "aparelhos ideológicos do
Estado" e, pois, como arenas políticas, como espaços a serem
democratizados. (1984, p.10)

Esse cenário vai favorecer a atuação das agências de fomento na área cultural, com características clientelistas e assistencialistas. No primeiro caso, as agências agem de maneira "passiva" (sem dirigismo), atendendo aos pedidos da área, com recursos financeiros para a execução de um projeto cultural. No segundo caso, vão atender aquelas áreas que têm dificuldades para sobreviver no mercado da indústria cultural. Fato é que mesmo diante dessa falta de um comando e controle centralizado por parte do Estado, essas agências de fomento deixaram um legado de programas e projetos culturais de inquestionável qualidade. (MACHADO, 1984, p.9)

Um exemplo disso, resguardando as especificidades da sua condição jurídica, a Embrafilme pode ser considerada como uma agência de fomento da área cinematográfica, num momento em que o cinema nacional buscava ampliar sua participação no mercado nacional, com produções que aliavam qualidade artística e apelo comercial. A empresa assume uma posição de patronato, ao intervir e estimular a produção nacional, mas suplanta essas atribuições ao atuar também na distribuição do filme nacional.

Devemos considerar, também, o fato de que o trabalho cultural desenvolvido pelas instituições públicas federais tenha tido, desde sempre, um caráter patrimonial, voltado à restauração de monumentos e obras antigas (IPHAN, por exemplo), a resguardar atividades artísticas e elementos ligados a manifestações populares que já não encontram lugar no mercado de bens culturais. Esta postura patrimonial está presente em muitas das atividades até mesmo de órgãos ligados às atividades executivas, como a Funarte, a Embrafilme, o INL e o SNT. (MICELI, 1984, p.102) Portanto, é importante ressaltar que uma parcela substantiva dos recursos públicos destinada à cultura vai minimizar as dificuldades de áreas que não têm condições materiais de sobreviverem, por não terem espaço no mercado privado de 
entretenimento.

[...] a força política e cultural da vertente 'patrimonial' deriva da disjunção crescente entre o produto veiculado pelos meios de comunicação de massa, operando em bases comerciais capitalistas, e os bens culturais, subsidiados a fundo perdido, por entidades governamentais ou por outras modalidades oficiosas de mecenato. (MICELI, 1984, p.105)

Segundo Williams,

[...] quando a obra se tornou mercadoria, produzida para ser vendida com lucro, os cálculos internos de qualquer tipo de produção de mercado levam diretamente a novas formas de controle cultural e especialmente de seleção cultural. Tornamo-nos tão habituados às relações de mercado que pode parecer simplesmente banal observar que tipos de obras que dão prejuízo serão, na produção de mercado, reduzidos ou não terão continuidade, enquanto tipos que dão lucro se expandirão. (2000, p.103)

O trabalho dessas agências de fomento ganha mais importância e abrangência quando o regime passa a oferecer apoio oficial à modernização da indústria da cultura e da comunicação, como parte do projeto estratégico de integração nacional, ou, conforme avalia Napolitano, uma forma indireta de política cultural, que oferecia. (2010, p.150)

\begin{abstract}
Concomitante à censura e à repressão política ficaria evidente, na década de 1970, a existência de um projeto modernizador em comunicação e cultura, atuando diretamente por meio do Estado ou incentivando o desenvolvimento capitalista privado. A partir do governo Geisel (1975-1979), com a abertura política, especialmente por intermédio do Ministério da Educação e Cultura, que tinha à frente Ney Braga, o regime buscaria incorporar à ordem artistas de oposição. (RIDENTI, 2005, p. 98)
\end{abstract}

Williams (2000, p.55) destaca que em determinadas sociedades capitalistas - e na maioria das pós-capitalistas - as instituições culturais transformaram-se em departamentos do Estado, na medida em que muitos dos produtores trabalham mais para o Estado, ou o representam, do que para o próprio mercado. Também podemos encontrar instituições culturais totalmente subordinadas à política estatal, em razão do monopólio dos meios de produção cultural e também outras que seguem a orientação de uma maneira mais geral, mas que mesmo assim mantêm uma relação de subordinação presente no patronato moderno.

Observa-se, também, durante o regime militar, o nascimento da indústria cultural no Brasil, com a participação da televisão, do mercado editorial, fonográfico e da 
publicidade. Profissionais da área artística e mesmo intelectuais eram, frequentemente, empregados nas agências de publicidade, mercado que teve um grande crescimento motivado pelo fato de o Estado ser o principal anunciante nos meios de comunicação de massa (como o é até hoje).

Assim, do ponto de vista de uma estratégia global, os media, a cultura de mercado funciona como dispositivo de mobilização e integração das populações - portanto, como um tipo de administração ou gestão da vida social - e não como mediações explicitamente políticas (geradoras de civitas) ou pedagógicas (aptas a suscitar a compreensão e a descoberta) dentro do modelo democrático tradicional. Trata-se, no entanto, de uma cultura dissimuladamente político-pedagógica. Nela, pedagogia e política disfarçam-se sob uma roupagem estética ou simplesmente retórica. (SODRÉ, 1984, p.141)

O avanço na economia veio acompanhado de maior consumo, principalmente de bens culturais, que passam a ser oferecidos em escala industrial, como os produtos televisivos, livros e coleções de fascículos, novas revistas, enfim, foram anos de crescimento do mercado cultural, incentivado pela promoção de produtos de fácil assimilação, em especial na música e televisão, um aumento que indicava uma nova tendência "industrial e "massiva" do consumo cultural, que se consolidaria de vez na segunda metade da década de 1970". (NAPOLITANO, 2008, p.82)

O Estado vai chamar para si a responsabilidade de manter viva a memória nacional, e assim se transforma no criador e guardião da identidade nacional. A cultura, vista como uma forma de comunicação de um indivíduo, ou de um grupo com o universo, pode ser uma herança recebida, mas é também um reaprendizado baseado nas relações do homem com seu meio (SANTOS, 2007, p.81), por isto passa a ser orientada pelo regime.

Dessa maneira, o nacionalismo converte uma prática histórica numa substância imortal. Num ídolo, muitas vezes com apetite sangrento. Compreende-se, então, porque os vários nacionalismos se preocupam tão intensamente em produzir a identidade nacional, que, na prova a priori, é deduzida das etnias, dos costumes, da língua, da família, dos sentimentos comunitários "naturais", e, na prova a posteriori, é deduzida do Estado. Frequentemente as duas provas se combinam e seu resultado costuma receber o nome de política cultural. (CHAUÍ, 1999, p.114-115) 


\subsection{A CENSURA: 1964-1985}

O período compreendido entre 1946 e 1985 é marcado por profundas mudanças em um mundo que emerge da II Guerra Mundial, num esforço de reconstrução dos países nela envolvidos. A polaridade entre capitalismo e comunismo e a Guerra Fria faz surgir nas sociedades ocidentais a prática do monitoramento permanente, em razão da preocupação das elites políticas e dos militares com os perigos da influência dos pensamentos de esquerda, que poderiam estimular a agitação social, estimular a adesão a um modelo de igualdade social, visto no comunismo.

Assim, tanto a produção nacional, quanto a estrangeira, do cinema eram muito visadas pela censura, pois traziam as mais variadas temáticas carregadas de simbolismos, alguns mais e outros menos explícitos, que suscitavam o questionamento e o debate, coisas que para os militares e para os setores mais conservadores da sociedade eram tidas como elementos subversivos e de agitação social.

Foi um período em que se podiam ver filmes com conteúdos mais voltados à denúncia social, especialmente aqueles focados no registro da realidade social e política, como o neorrealismo italiano ou mesmo no cinema norte-americano, nos filmes Uma Rua Chamada Pecado e A Morte do Caixeiro Viajante, nos quais a realidade das ruas e das cidades passava a integrar, de uma maneira intensa, seus roteiros. Assim, por intermédio da realização de diversos filmes, o cinema passava a expor a denúncia social, o desajuste e a crítica a uma sociedade desumana.

São bons exemplos para ilustrar a produção brasileira do período os filmes Veneno (1952), de Giani Pons, drama psicológico e com cenas de violência, da Vera Cruz, censurado para maiores de 18 anos devido à temática, bem como alguns dos censurados Anjo do Lodo (1951) de Lulu de Barro, da Cinédia e Rio, 40 graus (1955) de Nelson Pereira dos Santos, que recebe esta observação do censor: “...as várias histórias que compõem o referido filme apresentam tipos de delinquentes, viciosos e marginais, cuja conduta em certo ponto é até enaltecida." (SIMÕES, 1999, p.46)

A censura brasileira se manifestava através de posições extremamente moralistas, como a do vereador Gladstoner Chaves de Melo que, nos seus discursos no legislativo, se referia à "obra de baixo teor moral e da mais deslavada pornografia" para explicitar sua reprovação a algum trabalho artístico, ou como outro deputado de São Paulo, que reclamava da pornografia reinante. Havia, principalmente nos anos 
1950, um padrão moral vigente conservador, em alguns casos fortemente calcados em valores católicos. A liberdade de expressão era tolhida por aqueles que se julgavam no direito de escolher o que poderia ou não ser exibido; a censura se tornava instrumento de poder para certos grupos que mantinham o controle sobre a cultura e a educação.

É dessa época a Confederação das Famílias Cristãs. Com atuação predominante em São Paulo era formada por comissões compostas de "pessoas idôneas dotadas de espírito cívico para avaliar os processos", intituladas de Moral e Costumes ou Orientação Moral de Espetáculos, e que tinham ascendência sobre o juizado de menores, a tal ponto de criar uma estrutura para reavaliar a liberação de espetáculos e filmes que era tradicionalmente feita pela divisão de Censura. (SIMÕES, 1999, p.50)

No Brasil de 1964, em plena Guerra Fria, a incorporação da Doutrina de Segurança Nacional no Brasil acelerou a prática da censura, principalmente após a instituição do Al-5, quando o Cinema Novo (com a visão de esquerda dos cineastas) se tornou seu alvo principal, como o filme de Ruy Guerra, Os Fuzis, de 1962, que virou até estudo de caso para os censores, que pontuaram suas principais características: "Fixação da Estética da Fome; desmoralização das crenças religiosas; exaltação à violência; solapamento das forças policiais; arregimentação das massas rurais; conscientização da intelectualidade burguesa face o drama da miséria das áreas do interior." (SIMÕES, 1999, p.109)

Outro exemplo emblemático da censura foi a exibição do filme Deus e o Diabo na Terra do Sol (1964) de Glauber Rocha, na antiga Agência Nacional, feita a uma restrita plateia composta de oficiais de alta patente para que fosse avaliada a reação do público. Alguns oficiais presentes na exibição manifestaram-se pedindo a queima dos negativos do filme, outros, menos inflamados, sugeriam: "Olha, temos que ver esse filme na moviola, porque a mensagem está nas entrelinhas." (SIMÕES, 1999, p.74)

A censura sempre foi praticada aqui no Brasil com base em critérios subjetivos, e em interpretações pessoais, o que tornava a atividade ainda mais problemática. A figura do censor se destaca de duas maneiras: pela sua falta de critério ou pela sua característica no corte, como é o caso do chefe da Censura à época, Pedro José Chediak (apelidado por alguns cineastas de "Chediak, o estripador"), que determinou o corte de quatro cenas do filme O Silêncio (1963), de Ingmar Bergman e terminou seu trabalho de corte justificando: "O Silêncio não tem mensagem alguma, é vazio. 
O Ingmar Bergman fez fama e deitou na cama." Outro exemplo seria o filme $O$ Desafio (1965) de Paulo Cesar Saraceni, que foi recebido pelos censores com desconfiança. "Ao final da projeção, um militar perguntava em voz alta: Desafio por quê? Quer desafiar quem?" Sete meses depois o filme continuava sem liberação. (SIMÕES, 1999, p.77-79)

Havia uma complicação a mais no trabalho da censura, que era a precária formação dos censores, que por total falta de conhecimento sobre o assunto a ser analisado, emitiam pareceres precários do ponto de vista da argumentação, que chegavam a envergonhar até seus superiores. Devemos destacar também que a mudança da capital do Brasil para Brasília acarretou uma grande perda do contingente de funcionários do Serviço de Censura. Os militares tentaram de tudo: promoveram concursos públicos exigindo para a função nível superior de escolaridade mínima, requisitaram funcionários de outros ministérios e repartições públicas. Porém, na falta de, digamos, gente qualificada, os cargos passam a ser ocupados por apadrinhados ou meros conterrâneos de autoridades públicas.

Os cursos rápidos de cultura cinematográfica não resolveram as carências básicas de formação cultural dos funcionários, muito mais receptivos aos ensinamentos proporcionados pela Academia Nacional de Polícia, em Brasília, que já inculcava conceitos de segurança nacional nos "intelectuais da Polícia Federal", como os censores eram chamados. (SIMÕES, 1999, p.89)

Vale reproduzir aqui a avaliação de dois censores, com opiniões bem distintas, digase de passagem, sobre o filme Terra em Transe (1967), obra de maior importância do cinema novo (SIMÕES, 1999, p.89):

Silvio Domingos Roncador, jornalista:

[...] $\mathrm{O}$ autor, contudo, perde-se muitas vezes, interrompendo a sequência natural e fluente da película, primariamente confundindo distorções formais da administração pública com ideais filosóficos.

Jacira Oliveira:

[...] Apesar da interpretação correta de todo o elenco, a película em apreço tem um enredo totalmente confuso, talvez um subterfúgio de que tenha lançado mão Glauber Rocha para poder realizar uma obra de fundo nitidamente subversivo sem ser molestado pelas autoridades de nossa Pátria.

A despeito dessa precariedade de formação, o regime militar brasileiro foi o 
responsável pelo mais profundo controle da área cultural, promovendo a censura e o cerceamento da expressão, recrudescido após a instituição do Al-5, em dezembro de 1968, mas iniciado em 1964. É neste ano que é criado o Serviço Nacional de Informações (SNI), com o propósito de produzir informações que ajudassem a Presidência da República em suas decisões. Porém, em 1967, sob o comando do general Emílio Garrastazu Médici, o SNI passa a ser o centro e a comandar a espionagem no Brasil.

Ao contrário do que supôs Golbery do Couto e Silva, que afirmou ter criado "um monstro", não foi ele, mas a linha dura, que gestou tal criatura. A vitória definitiva da corrente, representada pela decretação do Al-5, fez com que a espionagem passasse a atuar a serviço dos setores mais radicais, divulgando as avaliações que justificavam a escalada e a manutenção da repressão. (FICO, 2004, p.36)

\section{$(\ldots)$}

Portanto, é fundamental destacar que, se o anseio punitivo que caracterizava a linha dura não surgiu repentinamente em 1968, como reação à opção de parte da esquerda pela chamada "luta armada", de fato, a partir do $\mathrm{Al}-5$, as diversas instâncias repressivas já existentes passaram a agir segundo o ethos da comunidade de segurança e de informações ou com ela entraram em conflito. No primeiro caso, está a censura de diversões públicas; no segundo, a propaganda política. (FICO, 2004, p.37)

O sistema repressivo do regime tinha três pilares: informação, através do seu SNI, da Divisão de Segurança e Informações do Ministério da Justiça (DSI); vigilância e repressão policial, por meio das Delegacias de Ordem Política e Social (Dops) e dos Destacamentos de Operações de Informações/Centros de Operações de Defesa Interna (DOI-CODI); e a censura, que ficava sob a responsabilidade do Ministério da Justiça (MJ) e sua Divisão de Censura de Diversões Públicas (DCDP) do Departamento de Polícia Federal (DPF) e do Setor de Imprensa do Gabinete (Sigab), que fazia uma parte da censura à imprensa. (NAPOLITANO, 2010, p.151)

É lógico que esses sistemas pesaram fortemente na vida cultural do país, época em que alguns temas passaram a ser proibidos e assim calados. Outra questão a destacar é que durante todo o tempo do regime (entre 1964 e 1985) o sistema de repressão teve uma atuação irregular, ou seja, mais atuante em alguns períodos e em outros, menos. Na visão de Napolitano (2010, p.151-153), existiram três períodos de repressão na área cultural, que tinham objetivos estratégicos diferenciados, porém complementares. Seriam eles:

1 - O que vai de 1964 a 1967. Tinha como objetivo básico dissolver as conexões da 
"cultura de esquerda" com os movimentos sociais e as organizações políticas, como por exemplo o fechamento do ISEB e o fim dos movimentos de alfabetização de base. Também era feito o controle da imprensa através da instauração de inquéritos policiais militares e processos judiciais, o chamado "terror cultural". A censura sobre as atividades artísticas nesse período era desarticulada com altos e baixos, pois tinha como base legal uma lei relativa às diversões públicas de 1946.

2 - Situado entre o fim de 1968 e início de 1979. Nesse período a repressão se torna mais "orgânica e sistêmica", uma estratégia de Estado, e vai além da ação truculenta policial na área da cultura, atingindo agora a diversão pública. O foco desse período era neutralizar a cultura que naquele momento era um agente mobilizador em alguns setores da classe média, diminuindo assim o seu radicalismo, principalmente entre os estudantes.

O fato é que foi a partir de 1968 que o Estado se estrutura, tanto burocrática como legalmente e implanta uma forte censura nas manifestações culturais. A primeira ação foi a promulgação da Lei n. 5536/68, a lei da censura, direcionada ao teatro e ao cinema, e que institui o Conselho Superior de Censura. Dois anos depois, é assinado o Decreto n. 1077/70 que estabelecia a censura prévia sobre materiais impressos.

3 - Período que vai de 1979 a 1985. Tentativa de controlar a desagregação da ordem política até então sob controle, colocando limites no conteúdo e na linguagem, com apelo ao controle "moral", incentivo aos "bons costumes" e diminuição da censura sobre conteúdos políticos.

De um lado a censura, o exílio, o crescimento da cultura massificada, de outro, os críticos ao sistema buscavam novos caminhos e espaços para expressar suas opiniões, fazendo com que se formasse uma rede alternativa de produção cultural. Imprensa alternativa e o cinema marginal conseguiram contornar a vigilância do regime e ampliar sua abrangência, apesar das dificuldades financeiras.

A censura era a linha mestra da "política cultural" do regime, se é que seja possível existir política cultural e censura ao mesmo tempo. O responsável por colocá-la em prática era o DCDP, subordinado ao Ministério da Justiça, porém, outros órgãos mais próximos dos militares também interferiam no assunto, entre eles o $\mathrm{SNI}$ e os muitos centros de inteligência existentes nas Forças Armas.

Por meio da censura, o regime militar definia o que os brasileiros deveriam ou não assistir e mais, controlava ou omitia as informações que não eram favoráveis ao regime. Atuava por meio de uma estrutura repressiva representada por funcionários 
da Polícia Federal, apoiada por alas mais conservadoras da sociedade, que os mesmos diziam representar. Na verdade, apesar de se dizer envolvida com a preservação dos valores morais e dos bons costumes da sociedade, a censura estava comprometida mesmo em proteger o Estado e seus interesses.

O critério era, assim, muito aberto e subjetivo. Proibia-se a obra inteira ou se indicava cortes a serem feitos e autores considerados subversivos eram especialmente vigiados e censurados. Mas havia uma distinção na ação da censura, que era mais rigorosa com algumas áreas do que com outras.

Carlos Fico aponta a existência de duas censuras durante o regime militar: uma que controlava a imprensa e outra as diversões públicas. A censura praticada contra a imprensa era mais informal, ou menos ostensiva (embora tivesse diretrizes secretas), acontecia através de bilhetes, recados, telefonemas e controlava mais os assuntos ligados à política. A censura encarregada às diversões públicas, era uma velha conhecida das pessoas ligadas ao teatro, ao cinema, à musica e a outras áreas artísticas, pois já vista em outro governo ditatorial, o Estado Novo. Funcionários "especialistas", os censores, eram os encarregados de pô-la em prática. Havia inclusive um certo orgulho em trabalhar como censor, tido como um guardião da moral e dos bons costumes, portanto, bem visto por vários setores da sociedade brasileira. (2004, p.37)

Há alguma discussão sobre a intensidade e a sistematicidade da censura desse tipo em relação aos quatro anos posteriores ao Golpe de 64, mas a afirmativa de que não houve censura da imprensa nesta fase é quase uma ingenuidade, pois os anos do primeiro general-presidente não demandavam tanto esses serviços, haja vista a impressão geral de que a intervenção poderia ser breve. Houve problemas na área, como demonstra o fechamento do Correio da Manhã, e a censura da imprensa existiu quando necessária, mas de maneira episódica. Atacado por jornalistas, Castelo Branco decidiu deixá-los sem punição - o que demonstra que tinha como censurálos. (FICO, 2002, p.253)

Outra diferença entre essas "duas censuras" foi que a censura da imprensa acontece mais fortemente no período que vai do final dos anos 1960 e início dos anos 1970, ao passo que a censura das diversões públicas fica mais rigorosa a partir do final dos anos 1970, no processo de abertura. Mas isso não significa que a instituição do Al-5 não tenha sido um marco na maneira como a censura da imprensa atuava, agora de maneira mais sistemática e obedecendo ao comando do alto escalão do regime. A censura fazia parte do sistema repressivo e não entrava na discussão se a censura aplicada estava dentro da constitucionalidade ou não. 
A chegada de Costa e Silva (1967-1969) à presidência e o Al-5 indicam que a linha dura agora dominava o poder. Ela aprofunda um processo que já vinha em curso, instituindo um sistema nacional de "segurança interna", implantando a censura sistemática na imprensa, a instrumentalização da censura de diversões públicas para coibir aspectos políticos do teatro, cinema e TV, e outras. Desmontar tal estrutura foi um dos problemas enfrentados pelo grupo que conduzia a reabertura política do país. (FICO, 2002, p.255)

O governo Costa e Silva se esforçava para se mostrar um governo militar "humano", ao mesmo tempo em que era cobrado pelo grupo mais radical, da linha dura, sobre os avisos recebidos sobre o avanço do comunismo no Brasil. A interdição do filme "Terra em transe" era um sinal de que esse temor já se instalara no poder e conduzia suas estratégias.

Uma grande polêmica então se instala. A reação à interdição do filme de Glauber foi expressiva. À frente de importantes figuras do meio intelectual, o Conselho Federal de Cultura se posiciona contrário à interdição, saindo em defesa de Glauber Rocha, considerando que "esse tipo de violência era um desestímulo a um artista tão especial como Glauber, sendo, portanto, uma medida anticultural”. (SIMÕES, 1999, p.92)

Outra preocupação que ajudou na mobilização a favor da liberação do Terra em transe foi saber se o filme seria ou não apresentado no festival de Cannes. O governo militar ainda tentou junto à organização do festival, por meio do Itamaraty, excluir o filme da lista dos filmes que seriam apresentados, em vão. Havia então o entendimento entre os cineastas de que a interdição, por não ter sido ainda publicada no Diário Oficial da União (DOU), não seria válida, e assim o filme poderia ser remetido à França, legalmente. O impasse só foi solucionado quando o filme foi submetido a nova avaliação e liberado, sem cortes, mas com a condição de que o padre, um personagem do filme, tivesse um nome, de forma que a instituição Igreja não fosse confundida com suas ações. Liberado, o filme ganha em Cannes dois prêmios, mas deixou marcas e um rancor contra o Cinema Novo.

A proibição de Terra em Transe revelou-se um tiro na água, fato agravado pela liberação constrangida sob o argumento de que bastava dar um nome ao padre para evitar ofensas à Igreja, quando todos sabiam - Cannes inteira sabia! - que os motivos eram outros, de ordem política e ideológica, como fora enunciado pelas autoridades encarregadas da Segurança Pública. Os fatos provocaram irritação em ambientes militares mais "sensíveis", que precisaram engolir uma rebelião contra as determinações oficiais e aguentar um pedido de revisão com pressões vindas até do exterior. Tudo isso representava desprestígio, perda de pulso, falta de comando para colocar a 
patuleia em ordem unida. (SIMÕES, 1999, p. 94-95)

Era vista também uma colaboração da sociedade com relação ao controle do conteúdo da produção artística e cultural. Eram centenas de cartas que chegavam à DCDP denunciando o que se considerava impróprio e ofensivo à moral e aos bons costumes, pedindo que o material fosse censurado. Mas diferentemente do que pode pensar, o maior número de cartas não aconteceu no período de maior repressão (entre 1969 e 1974) e nem tampouco no período de maior censura, que se concentra entre 1976 e 1980.

Do mesmo modo, a maior porcentagem de peças teatrais censuradas,
dentre as submetidas à análise da DCDP, foi registrada em 1978
(quase 3\%). Quanto aos filmes, o maior índice verificou-se em 1980
(quase 1,5\%). Esta é mais uma diferença entre a censura da
imprensa e a de diversões públicas, pois é óbvio que a primeira teve
correspondência com o período de maior atividade repressiva. A
censura da "moral e dos bons costumes" obedecia a outros ditames,
embora não tenha ficado imune às peculiaridades do regime militar.
Ela dizia respeito a antigas e renovadas preocupações de ordem
moral, muito especialmente vinculadas às classes médias urbanas.
(FICO, 2002, p. 277)

No período que vai de 1969 a 1979, período em que a censura foi mais severa, tudo era previamente avaliado. Livros, revistas, filmes, peças de teatro, programas de TV e de rádio, enfim, tudo passava pelo crivo dos censores antes de serem liberados. $A$ salvaguarda da moral e dos bons costumes ficava como responsabilidade da DCDP, ligada ao DPF. Livros, revistas, programas de TV que abordassem temas comportamentais (sexo, droga) eram tidos como prejudiciais aos valores morais, que os censores se orgulhavam de proibir, diferente do que acontecia com os temas políticos, mas que nem por isso deixavam de ser censurados.

A DCPD vai então ampliar sua atuação, praticando também a censura política, ou seja, proibindo conteúdos que tivessem uma mensagem contrária ao regime. $\mathrm{Na}$ verdade a censura era a finalização do trabalho realizado pelas "comunidades de informações e de segurança", isto é, dos membros da "linha dura", que eram uma espécie de porta-vozes do regime, ocupados em defender os princípios do que eles chamavam de "Revolução". Os documentos produzidos por essas comunidades, em ritmo frenético, diga-se de passagem, construíam uma narrativa que legitimava as ações repressivas, vinculando a crise "moral" que a censura buscava controlar, com o "movimento comunista internacional", capaz de desencaminhar e incutir maus hábitos nos jovens, um caminho para a subversão. A censura então seria mais uma 
aliada na proteção do país contra os ataques do "inimigo" que queria fazer do Brasil um país "sem moral e respeito". (FICO, 2002, p.260)

O teatro recebeu grande atenção dos censores e teve 450 obras interditadas, no cinema aproximadamente 500 filmes, nacionais e estrangeiros, também tiveram o mesmo fim. Música e imprensa em geral sofreram com o rigor da censura e a literatura passou a ser alvo da censura depois de 1975, contradizendo a tendência da abertura do regime. (NAPOLITANO, 2008, p.101)

Em 1972, analisando o filme Os Inconfidentes, de Joaquim Pedro de Andrade, um parecer da DCDP dizia que "a Censura do DPF [Departamento de Polícia Federal] tem em vista [...] escoimar, e mesmo interditar, as referência negativas ideológicas ao atual regime do país". (FICO, 2002, p.258-259)

Havia também a autocensura que os proprietários dos meios de comunicação impunham aos seus empregados, interessados que estavam em ser beneficiados pela política de expansão da infraestrutura da comunicação promovida pelo regime. As redações dos jornais eram informadas sobre quais assuntos não poderiam ser publicados e essa orientação era repassada aos jornalistas que a cumpriam, em menor ou maior grau. Mas havia uma distância grande entre a autocensura e o colaboracionismo ou o apoio explícito ao regime. Segundo Carlos Fico

O caso da Rede Globo serve para exemplificar a complexidade do problema no campo da censura de diversões públicas. Dificilmente uma visão simplista, que entenda a emissora apenas como uma colaboradora do regime, conseguirá entender a censura no período. Note-se, inicialmente, um aspecto que ajuda a melhor esclarecer a distinção entre censura da imprensa e das diversões públicas que este artigo enfatiza: os telejornais da Globo não estavam adstritos à DCDP. Eles colaboravam francamente com o regime ou apenas acatavam as proibições determinadas para toda a imprensa. Mas as novelas, os programas de auditório, os shows musicais etc. eram ciosamente acompanhados pela censura de diversões públicas. Ao contrário do que já foi dito, esses programas foram extremamente prejudicados. No que se refere às novelas, por exemplo, a sistemática implantada pela censura obrigava, por assim dizer, a uma censura anterior à censura prévia, na medida em que as sinopses eram analisadas pela DCDP e, antes da elaboração dos capítulos, a emissora recebia recomendações sobre temas a serem evitados, comportamentos que poderiam gerar cortes e assim por diante. (2002, p.262-263)

Programas ao vivo eram acompanhados por censores, como o "Programa do Chacrinha" por exemplo, que chegou a ser detido por desacatar uma censora. Mas mesmo sendo punida, a Rede Globo prosseguia colaborando e sendo amigável com 
o DCDP. A emissora chegou até a contratar ex-funcionários da censura para fazer uma avaliação prévia dos seus programas, antecipando-se, assim, ao trabalho da censura oficial.

Pouco tempo depois de instituído o Al-5, um clima de apreensão toma os meios artísticos, intelectuais, estudantis e a sociedade brasileira. Muitos buscaram a clandestinidade para atuar contra o regime, outros a luta armada e muitos optaram (ou foram obrigados) a procurar exílio em países da Europa e América do Sul, criando comunidades que, mesmo distantes, acompanhavam o que acontecia no Brasil. Os militares, por sua vez, estavam cada vez mais atentos aos meios de comunicação, por considerarem que eram um foco de subversão e que na televisão neles acontecia a infiltração de comunistas e seus aliados.

Também no cinema, o "ciclo da pornochanchada" sofre com a radicalização. Até 1974-1975, esses filmes sofreram cortes indiscriminados, obrigando alguns produtores a recorrer a representantes em Brasília para conseguir liberar seus filmes. Alfredo Sternhein, diretor do filme "O anjo loiro", que teve quinze minutos cortados, dizia em 1975: "a censura obriga o cineasta a malabarismos esterelizantes". Segundo Alfredo, esses cortes faziam diminuir o interesse do público pelos filmes, pois estes estavam menos atentos à trama, e mais às imagens que alimentassem suas fantasias sexuais. (SIMÕES, 1999, p.185)

Diretores e produtores procuram então criar um padrão para os critérios que a censura adotava, de modo a especificar o tipo de corte ou enquadramento desejado em algumas cenas, para que pudessem adequar seus trabalhos à vontade dos censores e em especial sobre o enquadramento que deveria ser dado em cenas que tivessem nu feminino ou masculino, mais ainda no primeiro caso. Assim, muitas cenas foram refilmadas, títulos foram alterados, diálogos refeitos ou excluídos. Sternheim afirmava que dos 54 filmes lançados em 1973 em São Paulo, pelo menos vinte deles foram "mutilados". (SIMÕES, 1999, p.185)

E não foram apenas os filmes com conteúdos eróticos que passaram por esta "adequação", mas outros que os censores entendiam como sendo de conteúdo sexual, às vezes apenas pelo título que apresentavam. Isso aconteceu com o filme "Como era gostoso meu francês" (1970), de Nelson Pereira dos Santos, inspirado nas aventuras de Hans Staden (alemão, mas que no filme é retratado como francês) ao ser aprisionado por índios tupinambás, no século XVI.

No balanço final, o filme foi muito bem de bilheteria, com mais de 800mil espectadores, mas antes de chegar ao circuito teve de 
resolver na Censura o problema da nudez dos índios e do francês aprisionado. Em agosto de 1971 o filme é interditado em todo território nacional devido à nudez dos personagens, e Nelson, já prevenido para as eventualidades, explica: "Como todo mundo sabe, índio brasileiro nunca usou roupa, usava mesmo era a pele do corpo e pintura de jenipapo." (SIMÕES, 1999, p.168-169)

Ao mesmo tempo em que crescia a produção erótica, crescia a indignação e os protestos do segmento religioso a favor da defesa da família, ameaçada por esses filmes. Vê-se e reaparecem associações cristãs, em Minas Gerais e São Paulo e até alguns deputados federais levantam a bandeira de que a pornografia teria um efeito nefasto sobre a família brasileira. A própria atuação da censura, que era um instrumento do sistema repressivo, aproxima militares de grupos conservadores que pediam aumento do rigor para frear a imoralidade do cinema nacional.

Outro foco da censura foram os filmes apresentados nos Cineclubes, que existiam no Brasil desde os anos 1940, alguns a partir de organização de jovens ligados à igreja católica e outros ligados ao PCB. Nos anos 1970, os cineclubes estavam vinculados às faculdades, a sindicatos e eram um importante circuito alternativo, que apresentava uma programação com filmes mais engajados e também com muitos clássicos. O mais importante desses encontros eram os debates que aconteciam depois da projeção sobre a situação política do país. Claro que essas projeções eram acompanhadas de perto pela estrutura repressiva, mas sem que tenham conseguido acabar com elas.

A programação dos cineclubes incluía filmes de curta metragem que mostravam a realidade do país, muito diferente do que as novelas da Globo mostravam. Enquanto os curtas estavam sendo distribuídos informalmente, era difícil para os órgãos policiais terem algum controle sobre eles, quadro que muda totalmente com a criação da distribuidora Dina Filmes, que facilitou o controle fazendo com que e muitos filmes foram apreendidos pela Polícia Federal.

As relações do curta-metragem com a Censura funcionavam como num jogo de gato e rato. Proibido aqui, era exibido lá adiante num cineclube, sem chances de apreensão, porque essas projeções estavam excluídas da programação formal, não eram anunciadas nos jornais, fonte principal de pesquisa dos órgãos policiais. Mesmo quando a polícia chegava a tempo e a cena ocorria de vez em quando, ficava difícil sequestrar as latas que já estavam embarcando em alguma Kombi rumo ao desconhecido. (SIMÕES, 1999, p.199)

Ainda segundo Inimá Simões, o Brasil teve nos anos 1960 e 1970 uma substantiva produção de documentários com teor social, auxiliada pela chegada da bitola super- 
8, das câmeras mais leves de $16 \mathrm{~mm}$, do som direto e dos negativos mais sensíveis, que facilitavam o registro da rotina dos brasileiros pelos cineastas. O material produzido era exibido nos locais mais improvisados, como muros dos bairros mais afastados, galpões, sedes de sindicatos, etc. (1999, p.198)

Ernesto Geisel assume em 1974 a Presidência da República com a promessa de promover uma abertura "lenta, gradual e segura", ao mesmo tempo em que Golbery do Couto e Silva afirmava que o processo de distensão seria acompanhado de avanços e retrocessos justamente para garantir a segurança da transição. Essas declarações fazem aumentar as esperanças de que houvesse, finalmente, a liberalização do regime e que Golbery recebesse um elogio de Glauber Rocha, sendo muito criticado por isto. Com Geisel, temos a volta de Armando Falcão, também no Ministério da Justiça (o mesmo que dá nome à Lei que limitava o acesso dos políticos ao rádio e à televisão) e que ficou famoso ao se posicionar frente a questões importantes com um "nada a declarar".

Podemos então considerar que nos momentos de avanços do seu governo, Geisel procurou estabelecer uma aproximação com a classe artística, contando com a ajuda de Ney Braga, seu Ministro, que convida artistas como Chico Buarque, Jards Macalé, Sérgio Ricardo, entre outros para uma reunião e mais à frente, em 1975, também promove uma apresentação do filme "O amuleto de Ogun" (1974), de Nelson Pereira dos Santos, convidando o diretor, Joaquim Pedro de Andrade e Luiz Carlos Barreto (presidente do Sindicato dos Produtores cinematográficos), além de cantores da música brasileira. (SIMÕES, 1999, p.193)

Nos momentos que o processo se mantinha "fechado", a censura mantinha sua prática, mais fortemente no ramo editorial, pois os produtores cinematográficos brasileiros deixavam de apresentar os filmes à censura, esperando que houvesse alguma mudança no regime, e os filmes estrangeiros passavam por uma seleção prévia feita pelos próprios distribuidores, procurando trazer filmes que não desagradassem o regime.

O cinema brasileiro vivia naquele momento uma contradição, pois ao mesmo tempo em que a Embrafilme trabalha na defesa e na promoção do cinema nacional, o regime, pelas mãos da censura, trabalhava contra os interesses dos produtores, pois todo o tempo e dinheiro gastos na realização de um filme poderiam se perder, se o filme fosse censurado.

Censura e vigilância caminhavam juntas com a política de incentivo à produção cultural do regime, responsável pelo apoio financeiro a diversas obras, inclusive da 
área cinematográfica. Na verdade, essa iniciativa foi aparece no final dos anos 1960, com a criação da Embrafilme, sendo reforçada nos últimos cinco anos da década de 1970, quando surgiu o Concine, em 1976.

A posição do governo continuava ambígua: filmes financiados pela Embrafilme por vezes eram censurados; diferentes órgãos do Estado incentivavam e puniam uma dada produção. (RIDENTI, 2010, p.106)

Havia uma explicação, segundo Napolitano, para esse paradoxo de se ter a censura de um lado e o incentivo à produção de outro, que seria o fato de esse apoio ter crescido na medida em que a censura diminuía, ou seja, refletia a promessa do governo Geisel de implementar uma abertura política de forma "lenta, gradual e segura":

\begin{abstract}
Lembramos que o governo tinha uma política de "distensão" em relação aos artistas e jornalistas, como forma de diminuir o isolamento junto à opinião pública de classe média das grandes cidades brasileiras, leitora de jornais e consumidora de produtos culturais. A derrota surpreendente do partido oficial, a Arena - Aliança Renovadora Nacional -, nas eleições de 1974, havia deixado o governo perplexo com o comportamento do eleitorado das grandes cidades, e a aproximação com a imprensa e os artistas era um canal importante de comunicação entre Estado e sociedade. (NAPOLITANO, 2008, p.102-103)
\end{abstract}

Protestos de cidadãos chegavam, inclusive, com relação à Embrafilme, por ter financiado o "Bem dotado - O homem de Itu" (1979), de José Miziara, que contava a história de um homem que tinha um pênis gigante. A resposta da DCPD foi a de que o filme tinha recebido financiamento da Embrafilme e que ela é que deveria ser responsabilizada por promover obras sem valor. Na verdade, a DCPD não podia mesmo era impedir que todos os filmes feitos no Brasil fossem interditados, pois isto colocaria em risco a nossa indústria cinematográfica e os investimentos feitos pela estatal.

No caso de filmes nacionais financiados pela Embrafilme, "a proibição da censura não só causa prejuízo para o produtor como afasta a possibilidade da empresa estatal reaver o investimento aplicado". Por isso, a DCDP supunha facilitar a liberação dos filmes nacionais, sugerindo cortes e remontagens e evitando a interdição global. Para a Divisão, o problema deveria ser resolvido com a exigência de certificado de liberação para o roteiro antes dele ser submetido à Embrafilme. (FICO, 2002, p.267-268)

Outro caso que merece ser mencionado aqui é o filme "Dona Flor e seus dois Maridos" (1976) de Bruno Barreto, que sofreu cortes da censura em razão dos 
palavrões que o filme continha, mas que conseguiu ser liberado devido ao bom relacionamento do censor Coriolano de Loyola, com o produtor do filme, Luis Carlos Barreto. É fato que essa proximidade com os censores rendeu ao filme poucos cortes, e uma defesa contra o corte da cena que alegavam apresentar "prática sodômica" feita por um censor, que the causou problemas e o levou a pedir sua exoneração do cargo pouco tempo depois.

A liberação, logo após a queda do Ministro Silvio Frota, do filme "Lucio Flavio, Passageiro da Agonia" (1977) de Hector Babenco, que abordava justamente a temática até então proibida sobre a morte de um criminoso nas mãos do Estado, particularmente nas mãos de agentes policiais, é um exemplo dos conflitos que permeavam o final do governo Geisel.

Ainda que na gestão do Ministro Armando Falcão tivessem sido produzidos 4.470 filmes, segundo palavras do mesmo, devemos considerar que muitos desses filmes nem sequer eram citados ou encaminhados à censura, visto que o embargo seria certo.

No final de 1978, o governo Geisel na continuidade do processo de distensão, publica a emenda Constitucional $n^{\circ} 11$, que no seu artigo $3^{\circ}$ revogava todos os atos institucionais que fossem contrários à Constituição, dentre eles o Al-5.

Em 1979, já no governo Figueiredo, a censura vai aos poucos sendo enfraquecida, principalmente pelo início de funcionamento do Conselho Superior de Censura (CSC), que em pouco tempo de trabalho consegue liberar uma centena de filmes que estavam sob a guarda da DCDP. O resultado de anos de trabalho efetuado pela censura não é animador. Foram milhares de obras proibidas, interditadas, destruídas, perdidas, sem chance de serem recuperadas, sem contar com as obras censuradas pelas próprias distribuidoras, que nem chegavam às mãos dos censores e nem chegavam ao público.

A partir de 1980, algumas pornochanchadas foram liberadas pela censura, por ordem de juízes federais, causando um profundo desconforto nos censores que não gostavam que se pensasse que eram eles os responsáveis pela liberação.

Outras iniciativas, além da criação do CSC, puderam ser vistas no primeiro ano do governo Figueiredo. Segundo Inimá Simões: mudança de direção da Embrafilme, com Celso Amorim à sua frente, organização de seminários e simpósios, a divulgação de protestos contra a censura, etc.

Em maio, várias entidades reunidas na sede da $A B I$, no Rio de Janeiro, apresentam a Carta do Rio de Janeiro, documento final do I 
Encontro Nacional para a Liberdade de Expressão, que amplia o foco de atenção, incluindo as lutas contra o arrocho salarial, pela anistia e pelas liberdades democráticas, que vão unificando progressivamente vários segmentos da sociedade brasileira. O tom que marcaria 1979 foi dado no Festival de Cinema de Gramado, no Rio Grande do Sul, quando foram exibidos vários filmes proibidos ou em exame - Prata Palomares, Iracema e 25. (SIMÕES, 1999, p.224)

Morre Petrônio Portella, então Ministro da Justiça, assumindo Ibrahim Abi-Ackel, que interrompe o processo de abrandamento da censura. Embora negasse isso e afirmasse que não houvesse censura no Brasil, declara que ela poderia "apenas" ser utilizada em casos específicos que pudessem ofender os valores da sociedade brasileira, ou seja, novamente um critério aberto de censura que poderia servir a qualquer objetivo.

Filmes de cunho político foram rigorosamente avaliados antes de serem liberados para que essa liberação não colocasse em risco o processo de abertura, mas nem mesmo tanto cuidado foi suficiente para impedir que a tranquilidade do país fosse abalada com a explosão de bancas de jornal e de patrimônio público.

Em 1981 acontece a troca na chefia da censura. Entra Solange Hernandez, que toma posse em uma cerimônia reservada na sede da Polícia Federal. Segundo se afirmava a escolha se daria em razão da formação acadêmica de Dona Solange (como ela era chamada), mas de fato o que se pretendia era recrudescer o trabalho de censura, atendendo aos pedidos de setores mais conservadores, tanto do governo, como da sociedade. Dona Solange já começa declarando que havia muita liberdade nas manifestações culturais, mais ainda no cinema e na televisão.

Vários filmes são interditados e liberados com cortes de cinco e de até vinte minutos. Em 1982 é a vez de "Pra frente Brasil", de Roberto Farias, cair nas mãos de Dona Solange. O filme havia sido premiado em Gramado (cuja participação dependia de um certificado que reconhecia que o filme não comprometia nem autoridade oficial e nem qualquer instituição oficial), e era apontado como um marco por tratar da tortura praticada pelo Estado a presos políticos.

Recentes análises no processo de "Pra Frente Brasil", segundo Inimá Simões, indicam que muitas páginas com pareceres desapareceram, levando à conclusão que a própria diretora da Censura tinha interesses pessoais para interditá-lo, por isso tenha dado sumido com alguns dos pareceres favoráveis ao filme. Dona Solange, não satisfeita com o resultado do exame efetuado por três técnicos que decidiram pela liberação do filme, nomeou outros técnicos, que mais uma vez liberaram o filme, até que não Ihe restou alternativa senão a de proibir pessoalmente 
a obra. (1999, p.238-239)

O pessoal envolvido com o setor artístico à época considerava Dona Solange mais severa do que os censores da época mais dura do regime militar e, segundo membros do próprio CSC, costumava tomar atitudes contrárias à maioria dos censores. A diferença primordial desse novo período é que os abusos cometidos pela Dona Solange e outros censores eram agora autorizados a ser divulgados pela imprensa, uma abertura conseguida pelo próprio CSC.

O caso do filme "Em nome da segurança nacional" (1983), de Renato Tapajós é emblemático do poder de Dona Solange. Frente à indecisão dos censores, que confusos davam seus pareceres baseados em leis e decretos distintos, Dona Solange decide então pela interdição do filme com base na Lei de Segurança Nacional, isso no momento em que o país se encontrava em um período pré- eleitoral e assistia a volta ao país dos exilados, por conta da lei de anistia. O que indicava que a diretora da censura acreditava ser possível que a Lei de Segurança Nacional pudesse conviver com o regime democrático.

Em 29 de julho de 1985, o Ministro da Justiça, Fernando Lyra, anuncia o fim da censura, comprometendo-se a transformar o documento elaborado por uma comissão de intelectuais na "Lei Áurea da Inteligência Brasileira". Esse documento, que continha 21 itens, seria a base para uma legislação que organizaria a relação entre Estado e Censura. Nele, a censura passa a ser "classificatória", e os técnicos (antigos censores), não poderiam definir cortes nos filmes. Também foi extinto o CSC e surge o Conselho Superior de Defesa da Liberdade de Expressão, que tinha entre seus membros, representantes da sociedade civil. (SIMÕES, 1999, p.242-243) 


\section{HISTÓRIA E LITERATURA NO CINEMA NACIONAL: A PRODUÇÃO DA EMBRAFILME (1974-1978)}

\subsection{A HISTÓRIA NO CINEMA}

Os governos militares, que se instalaram no Brasil depois de 1964, assumiram a responsabilidade de preservar a memória nacional identificando-se como os criadores e guardiões da identidade nacional. O governo Geisel entendia que o incentivo à cultura poderia levá-lo a reconquistar o apoio perdido e ajudá-lo na reconstrução de sua imagem, bastante deteriorada, depois de anos de repressão política, controle social e cultural. Buscava-se, assim, legitimar ações e justificar a continuidade da presença militar no Estado brasileiro.

As diretrizes para a área cultural, norteadas pela PNC, definiam que a cultura seria a formadora da identidade nacional, sendo assim, proteger a memória e preservar as manifestações culturais seriam maneiras de defender a personalidade brasileira, de cuidar da segurança nacional e de manter a coesão em torno da imagem do regime. Suas diretrizes, já especificadas no capítulo anterior, indicavam as linhas gerais a serem adotadas no campo da cultura, destacando o resgate e a preservação da memória e do patrimônio nacional, o incentivo à criatividade e a difusão das criações e manifestações culturais, calcadas nos verdadeiros valores históricos, sociais e espirituais, que são característicos do homem brasileiro.

A questão cultural assume, assim, um papel relevante no processo de identificação do sentido de nação, de formulação do estatuto social e do viés ideológico, conduzido pelas classes dirigentes, que perpassa o plano político, econômico e social e que reflete um projeto mais amplo de manutenção dos interesses da classe hegemônica. A cultura, na ótica da PNC, seria capaz de contribuir para a construção e a descoberta da personalidade nacional, portanto, defendê-la significaria o mesmo que defender o território nacional.

Além dos objetivos básicos (conhecimento, preservação dos bens de valor cultural, incentivo à criatividade, difusão das criações e manifestações culturais e integração), a PNC orientava que, além do incentivo a ser dado às manifestações culturais regionais, o apoio deveria ser estendido à criação e não apenas ao produto final. As áreas contempladas seriam, por exemplo, a literatura, a música, o teatro, o patrimônio 
histórico e científico pela conservação de símbolos culturais da História do Brasil e a cinematografia nacional, dando-lhe base artística e tornando a sua produção mais competitiva, esta última relacionada a esta pesquisa, especificamente no que se refere à produção de filmes históricos e adaptações literárias, durante o período de 1974-1979, sob o apoio da Embrafilme, e se essa produção estava vinculada a uma política de governo direcionada a esses gêneros cinematográficos.

Por reconhecer a complexidade de definição do filme histórico e entender que um estudo mais aprofundado sobre a questão não estaria no escopo desta pesquisa, optou-se construir um entendimento sobre o filme histórico a partir das ideias de Ferro e Rosenstone, sem nenhuma pretensão de esgotar aqui toda discussão sobre o assunto.

$\mathrm{Na}$ medida em que a pesquisa busca identificar se o apoio dado pela Embrafilme para a produção de filmes históricos e de adaptações literárias estaria vinculado a um projeto de governo, entendemos ser fundamental apresentar algumas considerações sobre a importância da história e da memória na formação de uma unidade social e de uma identidade social.

É essencial destacar que a consciência do passado é fundamental para nosso bemestar, que depende do recordar aquilo que foi feito e dito, das histórias sobre pessoas e acontecimentos, "coisas comuns da memória e da história", e tem como base nossa memória, que nos traz as lembranças de fatos que aconteceram há tempos e nos dão a certeza de que tivemos um passado. Esse passado está presente na lembrança de cada um de nós, coexiste com o hoje, mas também se diferencia dele a partir de nossa reflexão, "...o pensar sobre nossas memórias, sobre a história, sobre a idade das coisas que nos rodeiam”. (LOWENTHAL, 1998, p.64-65)

\footnotetext{
A perda da memória aniquila nossa personalidade e sem ela nossas vidas perdem o significado. É preciso, pois, relembrarmos o passado para sabermos o que fomos e assim saber quem somos, ou seja, dar à nossa existência um sentido de identidade. (LOWENTHAL, 1998, p.82)
}

A construção de um processo discursivo, exaltando uma tradição forjada e amparada num suposto precedente histórico, atenua os conflitos que por ventura se instalem no âmbito social, um trabalho que, a partir do início do século $X X$, é desempenhado pela figura do historiador. Trabalhando de maneira independente ou mesmo dentro dos quadros burocráticos do Estado, o historiador tem um papel 
relevante nos planos social e cultural, na medida em que o resgate do passado histórico estará presente nos livros, nas narrativas da cultura popular, no folclore, nas biografias e na catalogação e preservação dos arquivos do Estado. Segundo Lowenthal, a "narrativa histórica não é um retrato do que aconteceu, mas uma história sobre o que aconteceu". (1998, p.111)

A reconstituição da memória cria um ambiente propício para que as mudanças e transformações desejadas sejam recebidas e incorporadas pela população e pavimenta o caminho para uma sociedade que transite entre a tradição e a modernidade sem tantos conflitos, conduzida para integrar e unificar um sentido de nação. Isto serve como base para que as mudanças, que se façam necessárias e que impliquem em inovações e transformações, venham de fato avalizadas pela forma discursiva, de modo a reforçar a ideia de que mudanças são inevitáveis. Elaborar um passado que busque incutir e reforçar normas e condutas, nos diferentes grupos sociais, de modo a institucionalizar novas práticas culturais.

\begin{abstract}
Em nossa própria cultura, os relatos históricos, tradicionalmente, têm servido a muitos propósitos além da "verdade" e, às vezes, estão em campos opostos ao dela - para assegurar a linhagem de soberano no poder, por exemplo, ou para promover o fervor patriótico ou ainda para apoiar causas religiosas ou revolucionárias. (LOWENTHAL, 1998, p.144)
\end{abstract}

Procuramos ligar nosso passado à memória coletiva, à história pública, transformando os acontecimentos públicos em experiência pessoal. Segundo Lowenthal:

Damos muito valor a essas conexões com o passado mais abrangente. Satisfeitos de que nossas lembranças nos pertencem, buscamos também ligar nosso passado pessoal à memória coletiva e à história pública. As pessoas recordam vividamente seus próprios pensamentos e ações em momentos de crise pública, porque se agarram à oportunidade de conectar-se com um cosmo significativo. (1998, p.82)

O trabalho de se manter viva a memória nacional deve ser constante, pois as lembranças, quando revistas, tendem a se modificar à luz do presente. Com o tempo, acabamos por esquecer imagens desagradáveis e valorizar as agradáveis, um modo de manipular e enriquecer o presente. Segundo Lowenthal, a memória e a história precisam combinar, comprimir, enfatizar ou suprimir alguns momentos do passado para transformar o que contam, em algo compreensível e crível. Do seu lado, o ouvinte transforma essas palavras em imagens, que não são as mesmas do 
historiador ou de quem conta um fato. (1998, p.96, 98, 114)

Procuramos então ligar nosso passado à memória coletiva, à história pública, transformando os acontecimentos públicos em experiência pessoal.

Damos muito valor a essas conexões com o passado mais abrangente. Satisfeitos de que nossas lembranças nos pertencem, buscamos também ligar nosso passado pessoal à memória coletiva e à história pública. As pessoas recordam vividamente seus próprios pensamentos e ações em momentos de crise pública porque se agarram à oportunidade de conectar-se com um cosmo significativo. (LOWENTHAL, 1998, p.82)

Dentro deste contexto, o cinema vai trazer outra perspectiva em termos da construção de sentidos, uma nova forma discursiva que transcende a fronteira entre o verbal e não verbal, um novo campo de estudo para novos signos contidos na imagem fílmica, um outro paradigma de comunicação. Como uma nova forma de arte massiva, o cinema passa a apresentar o mundo através do poder sedutor das imagens em movimento e, rapidamente, incorpora, como a literatura já havia feito, os gêneros advindos do teatro grego: o drama, a comédia e o romance.

Nas primeiras décadas do século $X X$, os grandes produtores de cinema eram a França e os Estados Unidos. Com o advento da I Guerra Mundial, a França entra em declínio e Hollywood passa rapidamente a dominar o mercado mundial cinematográfico, em termos de produção, distribuição e exibição. A produção cinematográfica americana vai, aos poucos, passando por um processo de segmentação, de modo a atender as preferências de um mercado com um público cada vez mais plural. A segmentação traz, então, a necessidade de se dividir a produção cinematográfica em categorias, de filmes que tivessem afinidades temáticas, os gêneros cinematográficos, ou seja, uma classificação que possibilitaria estabelecer relações de semelhança ou identidade entre as diferentes obras cinematográficas, facilitando, assim, a colocação desses produtos no mercado. Dentre esses gêneros cinematográficos, podemos citar alguns para ilustrar: drama, romance, aventura, policial, faroeste, musical, documentário e, também, o filme histórico. Para Rosenstone o filme histórico também é um gênero (ou uma série de gêneros), com convenções, e que vem se desenvolvendo há pouco mais de um século. (2010, p.63)

Até então, a história era o campo das palavras, do texto escrito e dos historiadores. A possibilidade de transpor a história para a tela do cinema abriu, em muitos momentos, novas perspectivas, envoltas em intensa polêmica, pois o texto escrito, a 
princípio, era portador de uma verdade incontestável. O estatuto da imagem e a narrativa cinematográfica traduzia, em certos momentos, uma ambiguidade própria, dúvidas sobre fatos, críticas, principalmente sobre a forma como a história estava sendo contada.

O cinema vai, então, desestruturar anos de discursos construídos para manter o equilíbrio das coisas, desnudando o outro lado das instituições e das pessoas que, por muitos anos, ficaram ocultos. Para Ferro:

O filme tem essa capacidade de desestruturar aquilo que diversas gerações de homens de Estado e pensadores conseguiram ordenar num belo equilíbrio. Ele destrói a imagem do duplo que cada instituição, cada indivíduo consegue construir diante da sociedade. A câmera revela seu funcionamento real, diz mais sobre cada um, do que seria desejável de se mostrar. (1992, p.86)

Anteriormente o historiador desempenhava um papel, apoiado pelo Estado, que Ihe trazia prestígio social e o domínio de um saber quase inquestionável: selecionava as suas fontes, pistas ou documentos, avaliava e escolhia a metodologia, levantava hipóteses em função dos seus objetivos e em busca de respostas que esclarecessem suas indagações. Seu trabalho de pesquisa histórica tinha o compromisso de resgatar, fortalecer e glorificar a trajetória da nação. Portanto, a relação entre cinema e história, no que diz respeito à transposição de fatos ou personagens para a tela cinematográfica, é alvo de questionamentos, por parte de cineastas e de historiadores, tais como, a escolha de fontes que sejam confiáveis, se a representação condiz com a suposta realidade dos fatos trazidos pelas fontes, etc. (FERRO, p.81, 84)

O norte-americano Robert A. Rosenstone (2010), importante referência na discussão sobre o filme histórico, que além de pesquisar sobre o tema também colaborou como consultor em diversos filmes, reconhece que tanto um livro de história, como uma obra cinematográfica, apesar de serem resultantes de processos produtivos de natureza distinta, compartilham as mesmas limitações.

O autor entende que os filmes históricos atuam apenas como representações do passado, contudo, trazem uma enorme capacidade expressiva, com um alcance nunca experimentado pelo texto escrito, reforçando assim o potencial contido na obra cinematográfica, que pode contribuir para a formação da cultura histórica da sociedade contemporânea, fato que não deveria ser ignorado pelos historiadores. 
que vemos se movendo e falando em cenas que lembram o passado parecem mais vivas do que nunca ... [...] Visões e sons armazenados em filmes e fitas dão, cada vez mais, acesso aos acontecimentos passados e, cada ano que passa, adiciona ambos ao volume desses registros e a seu afastamento temporal. E eles não apenas asseguram, como ampliam enormemente a memória pessoal. (LOWENTHAL, 1998, p.178)

Rosenstone busca compreender o significado da entrada do cinema na seara da história, quais seriam as perspectivas do cinema nesse novo universo e se essas novas formas de linguagem e de narrativa (imagem e movimento), utilizadas para transpor o passado, poderiam então deturpar a compreensão deste último. O que é certo é que o filme exige do historiador tradicional uma atenção especial, que vai além da construção dos fatos baseados em escolhas de vestígios considerados importantes para serem incluídos em sua narrativa. O filme se permite inventar fatos, criar vestígios. Segundo Rosenstone, a invenção de personagens, diálogos e incidentes é parte indiscutível do filme histórico, o que pode ser entendido como uma visão mais abrangente do passado que se pretende transmitir, e que pode nos fazer pensar historicamente. (ROSENSTONE, 2010, p.19-23)

Sobre a fidelidade de se pesquisar o passado, Lowenthal nos diz:

Portanto, os historiadores que afirmam fidelidade única ao passado e escritores de ficção que reivindicam total isenção dessa fidelidade, enganam a si próprios e a seus leitores. A diferença entre história e ficção reside mais no propósito, do que no conteúdo. Sejam quais forem os mecanismos retóricos de que o historiador dispõe, os princípios de seu ofício proíbem-no, sabidamente, de inventar ou de excluir algo que afete suas conclusões; ao se denominar um historiador e a seu trabalho a história, ele escolhe que ela seja julgada pela exatidão, consistência interna e congruência com os registros remanescentes. E ele não se atreve a inventar um personagem, atribuir características desconhecidas ou incidentais aos personagens verdadeiros... (1998, p.133)

Portanto, é pertinente encarar o filme histórico como parte de um campo de representação e discurso que não tem compromisso em reproduzir verdades rigorosas acerca do passado (coisa que nem mesmo a história escrita consegue fazê-lo). A construção simbólica de um fato serve, muitas vezes, como uma contraposição ou provocação ao discurso histórico tradicional. Para encontrar significado histórico de um filme (ou de um livro), Rosenstone recomenda:

[...] trabalhar a uma certa distância. Se você se aproxima demais ou se apaixona pelos detalhes infinitos de uma imagem ou sequência específica, é provável que venha a perder a percepção do quadro ou argumento histórico mais amplo. Se você se afasta demais ou se 
refugia em considerações teóricas, os detalhes que constituem a matéria do passado perdem o foco. (2010, p.25)

O cinema vai então oferecer uma nova possibilidade para se ver e se compreender o passado, mais ainda porque, diferentemente da literalidade contida no enunciado das palavras, as imagens têm um poder de ampliar os sentidos. Os filmes têm a "licença" de utilizar os dados coletados de uma maneira mais aberta, possibilitando assim "ver" o passado com um outro olhar. Cineastas têm o domínio de outras regras, convenções, códigos, construção discursiva e práticas próprias da linguagem audiovisual, muito diferentes daquelas utilizadas pelos historiadores. Para Rosenstone:

\begin{abstract}
A nossa reação básica é pensar que um filme na verdade é um livro transposto para a tela, o que significa que ele deveria fazer a mesma coisa que esperamos de um livro: acertar os fatos. [...] Trata-se de um drama, uma interpretação, uma obra que encena e constrói um passado em imagens e sons. O poder da história na tela emana das qualidades singulares da mídia, da sua capacidade de comunicar algo não apenas de maneira literal (como se alguma comunicação histórica fosse totalmente literal) e realista (como se pudéssemos definir realisticamente o realismo), mas também, nas palavras de Lerner, "de maneira poética e metafórica". (2010, p.60)
\end{abstract}

Ainda o autor:

\begin{abstract}
Estou dizendo que uma narrativa ou argumento histórico seleciona apenas certos vestígios, e esses vestígios que são escolhidos, se tornam "fatos", designados à medida que vão sendo usados como parte da obra histórica. Para o diretor de um filme dramático que precisa criar - e é necessário enfatizar essa questão - um passado que satisfaça as demandas, práticas e tradições tanto das mídias visuais quanto da forma dramática, isso vai além da "constituição" dos fatos a partir de vestígios de evidências encontrados em livros ou arquivos e começar a inventar alguns desses fatos. (2010, p.63-64) (Grifos do autor)
\end{abstract}

Vemos muitas críticas ao filme histórico pelo fato dele não reproduzir, de maneira fiel e isenta, os fatos e eventos do passado, o que também acontece com o próprio texto escrito. Na narração acontece uma escolha das palavras, e no cinema, no lugar das palavras, escolhemos sequências de imagens, atores, cenários e locações, que juntos formam uma narrativa que resume acontecimentos passados, sem compromisso, inclusive, com a cronologia dos fatos. Portanto, comprimir o tempo, incluir diálogos e personagens, são recursos do roteirista para construir uma narrativa fílmica "capaz de tornar o passado interessante, compreensível e significativo". (ROSENSTONE, 2010, p.63-65) 
O fato é que essas ficções, que abrem uma janela para que possamos ver o passado agora no presente, são uma narrativa, um discurso histórico que, mesmo se valendo da "encenação" ou de metáforas, nos permitem ver as transformações no campo social, cultural e político de uma determinada sociedade.

Um aspecto a destacar é a existência, dentro campo cinematográfico, de três formas de narrativa fílmica histórica, existentes desde os primórdios do cinema: o longa metragem dramático, com enredo com forte teor moral e também meio e fim, produzido com objetivo comercial; o documentário, semelhante ao longa dramático, com a diferença de que boa parte de suas imagens não são encenadas, mas coletadas de arquivos históricos, entrevistas que, inclusive, podem "moldar" e dar uma visão mais abrangente do passado; e os filmes históricos de oposição ou inovador, feitos para contestar “...histórias perfeitas de heróis e vítimas, contadas pelos longas metragens e documentários clássicos”. (ROSENSTONE, p.35-36)

O autor exemplifica essa produção citando alguns cineastas que tentaram repensar a história, segundo ele, herdeiros de Eisenstein, colocando o coletivo no centro do processo e não o indivíduo, como Cacá Diegues que em seu filme Quilombo (1984) conta a história de Palmares (uma sociedade de escravos fugitivos), utilizando-se de atores com fantasias de carnaval, dançando ao som de um samba. Um outro diretor destacado por Rosenstone é Roberto Rossellini, considerado por ele como o mais produtivo cineasta de filmes históricos, que colocava em seus filmes pessoas comuns e não atores, cujas falas eram toscamente recitadas, ficando a cargo dos luxuosos cenários e figurinos a representação da realidade. (2010, p.37-38)

\footnotetext{
Cineastas criam filmes, e não teorias sobre filmes, e muito menos teorias sobra a história, o que significa que precisamos buscar em suas produções acabadas, e não em suas intenções declaradas, o entendimento do pensamento histórico que encontramos na tela. (ROSENSTONE, 2010, p.39)
}

Ferro enfatiza a vantagem do uso cinema como documento histórico e que o mesmo deve ser observado como um produto e, como tal, possui significados não apenas cinematográficos. Portanto, seu valor não está apenas no que ele presencia, mas, sobretudo, na “...abordagem sócio-histórica que autoriza”. Para Ferro, o filme vai falar de uma outra história, não a oficial, mas a história dos setores da oposição, a contra-história. (1992, p.87)

Cabe destacar que em muitos momentos é vista uma proximidade entre a história tradicional e o documentário, pois se confere a este último, diferentemente do que 
acontece com o longa metragem, uma presumida noção de autenticidade, específica, que Ihe autorizaria a significar a realidade. O documentário, segundo Rosenstone, mesmo se valendo de muitos aspectos do filme ficcional, continua sendo visto como uma representação direta do que aconteceu no passado. (2010,

p.110)

\begin{abstract}
Mais importante, durante pelo menos a primeira metade do século, os acadêmicos tinham certeza de que o seu tipo de conhecimento sobre política, a economia e a vida social e cultural do passado era "verdadeiro", e estavam convictos de que a cultura em geral, aceitava as verdades sobre o passado que os historiadores profissionais podiam fornecer. Mas, após meados do século, à medida que as afirmações da história tradicional e de suas metanarrativas eurocêntricas começaram a ser questionadas por uma série de disciplinas e grupos - feministas, minorias étnicas, teóricos póscoloniais, antropólogos, narratologistas, filósofos da história desconstrutivistas e pós-modernistas -, desenvolveu-se um clima que permitiu que os acadêmicos passassem a levar a cultura popular mais a sério e começassem a observar mais de perto a relação entre filme e conhecimento histórico. (ROSENSTONE, 2010, p.40-41)
\end{abstract}

Mas acontece uma mudança, em meados dos anos 1970, quando o filme histórico passa a ser visto como um instrumento de ensino, como o historiador D. J. Wenden, da Universidade de Oxford, que reconhece a possibilidade de o filme Encouraçado Potemkim, de Sergei Eisenstein, ainda que bastante ficcionalizado, lançar uma luz e clarear um acontecimento histórico. Wenden, ao comparar os relatos do filme relativos à revolta no navio e os relatos históricos sobre o mesmo acontecimento, concluiu que Eisenstein construiu uma narrativa da revolta como símbolo do esforço revolucionário do povo russo em 1905. (ROSENSTONE, 2010, p.42) Assim, vê-se uma nova possibilidade de se resgatar o passado, por meio de uma simbologia construída através das imagens, diferente daquela narrativa construída pelo historiador nas mídias impressas.

Ferro vai se aprofundar na questão do filme histórico (a narrativa que constrói um discurso histórico), abrindo duas perspectivas de análise: testemunho do presente (o filme lido através da história) ou como discurso sobre o passado (a história lida através do cinema). Se, no passado, o texto impresso estava envolvido numa aura de credibilidade, para Ferro esta mesma abordagem poderia ser discutida através do registro cinematográfico. O autor ressalta que aquilo que “...nem sempre é muito evidente quando se escreve um livro, aparece imediatamente durante a realização de um filme", deduzindo então que o cinema ultrapassava as limitações da palavra escrita. A simples escolha do tema não garantiria um bom resultado para a obra 
fílmica, pois ela vem acompanhada de diferentes questões e variáveis, igualmente complexas, como a definição de gênero, a montagem e a forma narrativa. (FERRO, 1992, p.73)

Um questionamento surge, mas que história é essa a ser restituída? Ferro investe na questão da carga ideológica da história resgatada, pois a leitura que o historiador faz desta transposição para o cinema (narrativa visual) é para ele resultante da versão e anuência de interesses das classes sociais dominantes e da hierarquia do poder:

A História é compreendida do ponto de vista daqueles que se encarregaram da sociedade: homens de Estado, magistrados, diplomatas, empreendedores e administradores. Foram eles, precisamente, que contribuíram para a unidade da pátria, para a redação de leis sagradas que nos fazem livres, etc. (FERRO, 1992, p.82)

Ainda em Ferro:

Ora, no início do século $\mathrm{XX}$, essa hierarquia reflete as relações de poder: à frente do cortejo vão, prestigiosos, os Arquivos do Estado, com manuscritos ou impressos, documentos únicos, expressão de seu poder, do poder das Casas, parlamentos e tribunais de contas. Em seguida, vem a legião dos impressos que não são secretos: inicialmente textos jurídicos e legislativos, expressão do poder, e a seguir jornais e publicações que não emanam somente dele, mas da sociedade cultivada inteira. (FERRO, 1992, p.82)

Diferente de Rosenstone, que fala do status de credibilidade conferido ao historiador no sentido do resgate da história, do domínio do texto impresso, agora abalado pela linguagem cinematográfica de gênero documental, Ferro vai mais longe, aprofunda o tema e coloca um dilema para o historiador: libertar-se das instituições que o coloca na posição de fonte única da história, como os partidos políticos, os governos, as igrejas e os sindicatos, que acreditam ser a consciência da sociedade. Caberia, então, ao historiador desconstruir essa ideia. (1992, p.76-77)

Para a elite instruída do início do século XX (clero, militares, professores, magistrados), o cinematógrafo era visto como um "espetáculo dos párias", das classes populares, já que consideravam como crível apenas o que era escrito e tinha autoria.

Além do mais, como confiar nos jornais cinematográficos, quando todo mundo sabe que essas imagens, essa pseudo-representação da realidade são escolhidas, transformáveis, já que são reunidas por uma montagem não-controlável, por um truque, uma trucagem. O 
historiador não poderia se apoiar em documentos dessa natureza. (FERRO, 1992, p.83)

O cinema vai ascender, passa de popular para artístico, e se torna uma grande indústria, construindo formas narrativas diferenciadas para os usos mais diversos: ficção, documentário, jornais cinematográficos, filmes de propaganda política. Ferro enfatiza os governos democráticos e também as ditaduras totalitárias, como Itália e Alemanha, perceberam o grande potencial subliminar das imagens, seja como simples entretenimento, seja como tomada de consciência ou mesmo para alcançar seus interesses. (1992, p.13-14)

O grande impulso se situa na guerra de 1914-1918. Sem dúvida, desde o final do século XIX já havia câmeras filmando personagens e acontecimentos, principalmente tudo o que se relacionasse com as famílias reais. Um longo "assunto" foi consagrado ao jubileu de Vitória, em 1897; um outro às diferentes atividades do jovem Guilherme II. (FERRO, 1992, p.70)

Ainda em Ferro:

Os filmes de propaganda desse tipo multiplicaram-se com a guerra de 1914-1918, sob impulso dos serviços cinematográficos nos exércitos. As empresas privadas contribuíram para isso. Entretanto, a câmera teve por função principal o registro do real, particularmente do armamento do inimigo. Foi com esse fim, por exemplo, que os alemães instalaram câmeras automáticas nas trincheiras. (FERRO, 1992, p.71)

O filme precisa ser entendido também como um documento do seu tempo. O gestual das pessoas, os edifícios, a moda, pessoas andando na rua, compõem uma outra história, diferente da história narrada. Como nos diz Nóvoa:

\footnotetext{
"É preciso considerar a história a partir das imagens", diria Ferro. Não procurar nelas apenas a confirmação ou a negação de um outro saber, o da tradição escrita. Para considerá-las, tal e qual, ainda que seja para evocar outros saberes, ou para captá-los melhor, faz-se necessário associar o produto cinematográfico ao mundo que o produz. A hipótese da qual se parte é que o cinema é história, imagem ou não da realidade, documentário ou ficção. (2008, p.30)
}

Existem também duas possibilidades de se ver o filme: como um testemunho do presente (o filme lido através da história), um documento primário ou como um discurso sobre o passado (a história lida através do cinema), neste caso um documento secundário, sendo que para Ferro a análise do filme feita como documento primário é mais importante, já que mesmo que o filme tenha uma temática 
aparentemente centrada no passado, ele fala muito mais do presente. (PINTO, 2004, p.5)

\begin{abstract}
Diante disso, os filmes podem e devem ser tratados como documentos para a investigação historiográfica, do mesmo modo que a literatura, a pintura, a arquitetura e os monumentos. Para a ciência histórica, o fenômeno cinematográfico assume uma dimensão ainda mais importante que o da literatura. Isto foi demonstrado, de modo irrefutável, pela experiência do século. O cinema tornou-se um insubstituível instrumento de produção e difusão, não de consciência real, muito menos de ciência, mas de massificação de ideologia mantenedora do status quo. (NÓVOA, 2008, p.33)
\end{abstract}

A partir dos anos 1970, o cinema passa a ser considerado como um novo objeto ${ }^{41}$ para o estudo da chamada "História Nova" ${ }^{42}$, um movimento das décadas de 1960 e 1970, que entendia a importância da diversificação das fontes a serem utilizadas na pesquisa histórica.

\begin{abstract}
Para Ferro, o cinema é um testemunho singular de seu tempo, pois está fora do controle de qualquer instância de produção, principalmente do Estado. Mesmo a censura não consegue dominálo. O filme, para o autor, possui uma tensão que the é própria, trazendo à tona elementos que viabilizam uma análise da sociedade diversa da proposta pelos seus segmentos, tanto o poder constituído quanto a oposição. (MORETTIN, 2007, p.40)
\end{abstract}

A avaliação de Ferro, ao longo do tempo, dentro da sua perspectiva de constituir um corpo teórico a respeito das suas formulações sobre o filme histórico, indica a própria condição e natureza específica deste tipo de produção, que traz no seu discurso narrativo um forte componente dialético e ideológico e que possui, paralelamente à história projetada na tela, uma outra história, que necessita ser vista mais detalhadamente pelo historiador, que está além do visível, já que a imagem cinematográfica precisa ser analisada dentro de uma outra contextualização, que a distingue da mera forma ilustrativa como discurso.

Na medida em que o filme precisa ser entendido, também como um documento do seu tempo, deve-se então analisá-lo considerando o cenário político-econômico no

\footnotetext{
41 A revista de estudos históricos Annales d'Histoire Économique et Sociale, fundada em 1929 por Lucien Febvre e Marc Bloch, historiadores, vai propor, nos anos 1970, sob a direção do também historiador Jacques Le Goff, que a história poderia ser analisada não só pelos instrumentos tradicionais de pesquisa, mas também pelo que foi designado de "novos objetos", dentre eles, depoimentos orais, produções teatrais e cinematográficas, pelas artes, entre outros.

${ }^{42}$ Esse movimento de renovação da historiografia francesa, denominado "Nova História", teve como uma de suas mais importantes características a identificação de novos objetos e novos métodos destinados à pesquisa histórica, contribuindo para uma ampliação quantitativa e qualitativa dos domínios já tradicionais da história e enriquecendo o estudo e a explicação das sociedades através das representações feitas pelos homens em determinados momentos históricos.
} 
qual ele se insere, inclusive suas relações com a censura e o público, com as instâncias estatais de financiamento, suas formas de produção e comercialização.

O filme, seja qual for, desde então, passou a ser encarado enquanto testemunho da sociedade que o produziu, como um reflexo - não direto e mecânico - das ideologias, dos costumes e das mentalidades coletivas. Como não enxergar, por exemplo, tratando- se do Brasil, elementos da ideologia da esquerda brasileira - influenciada pelo modelo de reflexão da arte e da sociedade adotado pelos Partidos Comunistas em todo o mundo - nas primeiras produções do movimento cinemanovista, em início dos anos 60? Ou, em outro exemplo, como não perceber a atmosfera da ideologia macarthista nos filmes produzidos nos Estados Unidos durante as décadas de 1950 e 1960? (NOVA, 1996, p.3)

Na opinião de Ferro, o cinema permite-nos conhecer regiões inexploradas e cabe a nós abrir as portas que nos levem a esses novos caminhos, ou seja, devemos descobrir as lacunas deixadas pelo diretor e pelo seu filme, muitas vezes não intencional. Ainda segundo o autor, um mesmo filme pode suscitar diferentes leituras sobre o mesmo fato, uma tensão própria de sua estrutura interna. (MORETTIN, 2007, p.41)

Não acreditamos, no entanto, que a análise das relações entre
cinema e história possa ser elucidada a partir das dicotomias
"aparente" - "latente", "visível" - "não-visível" e "história" -"contra-
história". A ideia proposta pelo historiador de que o cinema não é
uma expressão direta dos projetos ideológicos que lhe dão suporte
deve ser ressaltada: um filme apresenta, de fato, tensões próprias.
Essas, porém, não devem ser pensadas nos termos de sua inclusão
ou no campo da "história" ou de sua "contra-história", tal como faces
opostas de uma mesma moeda, parti-pris que define um único sentido
da obra. Por outro lado, afirmar a possibilidade de recuperar o "não-
visível" através do "visível" é contraditório, já que essa análise vê a
obra cinematográfica como portadora de dois níveis de significado
independentes, perdendo de vista o caráter polissêmico da imagem.
(MORETTIN, 2007, p.41-42)

Ferro destaca que o filme pode desempenhar muitas vezes um duplo papel, ou seja, possuir um caráter independente em relação ao poder externo e, ao mesmo tempo, ser um veículo que se transforma num instrumento para pessoas, ou certos grupos sociais, expressarem as suas demandas sociais.

A contra-história, via cinema, se apresenta em sua forma mais cristalina, quando grupos marginalizados pela sociedade assumem o controle da produção de imagens. Nesse momento, teríamos um ponto de junção entre a natureza histórica do cinema enquanto possibilidade de "revelar" o inverso da sociedade e a origem social desses grupos, uma vez que estes representam esse inverso. Por 
serem excluídos, não participam nem da representação da sociedade elaborada por uma de suas partes que, entretanto, apresenta-a como pertencente ao todo - e nem do poder instituído. (MORETTIN, 2007, p.43)

É importante enfatizar que o cinema é também decorrência do imaginário da sociedade e está inserido em um contexto maior (crenças, imaginário do homem), e na própria história da sociedade, portanto, é necessário sempre observar que, como diz Ferro, “...todos os filmes são objetos de análise”. (MORETTIN, 2007, p.49)

O autor entende que todo filme, sem privilegiar nenhum gênero, deve ser analisado pelo historiador. A obra cinematográfica traz informações fidedignas a respeito do seu presente. A recuperação dessas informações exige do pesquisador conhecimentos teóricos e técnicos, como veremos a seguir. A noção de autenticidade, surgida da necessidade de se compreender exatamente o que se passou, a realidade de um dado momento histórico, permeia toda a sua discussão. (MORETTIN, 2007, p.48)

Além do mais, como observa Ferro, o estudo de um documento fílmico deve ser feito sob diferentes aspectos, como seus enquadramentos, planos sequenciais ou mesmo por uma apurada análise que procurasse identificar a utilização de formas deliberadas de modificação do documento fílmico, por meio da reconstituição: ângulos, distância das diferentes imagens de um mesmo plano, e mesmo o uso da iluminação no sentido de desnudar claramente o espaço cênico. Ainda segundo Morettin:

\begin{abstract}
A busca do "documento intacto" constitui um dado importante quando nos ocupamos do cinema via Ferro. Essa ideia permeia outras informações, como a que sustenta uma oposição entre história e contra-história (com os filmes de grupos sociais marginalizados jogando pesado nesse sentido, como vimos). Para que se realize como contra-história, o cinema deve se ancorar em procedimentos que validem a sua representação. (MORETTIN, 2007, p.50-51)
\end{abstract}

Uma perspectiva se dá através do "discurso novelesco", quando a obra fílmica, sem utilizar o suporte do discurso histórico, apresenta uma ideologia difusa, que possibilita ao autor subverter esse mesmo discurso histórico instituído, constituído por qualquer ideologia, atuando de maneira subliminar, mas na verdade expondo a sua visão para a temática retratada, sem que seja efetivamente notada. (MORETTIN, 2007, p.55)

Há talvez um grande ponto de convergência entre Marc Ferro e Robert Rosenstone: que o cinema cria uma forma narrativa bem diferente das tradicionais, que passavam pelo universo da literatura e, desta forma, o filme histórico permite o resgate de 
um passado desaparecido há muito tempo.

O filme histórico cria de fato uma forma narrativa visual que é muito mais estimulante para o grande público, mesmo que reconheçamos, em certos momentos, a imprecisão de fontes e pistas, sobre fatos, personagens ou eventos históricos, mas, mesmo com essas falhas, oferece uma perspectiva de análise histórica, com possibilidades de releituras do nosso passado.

Contudo, entre os autores há também discordâncias, como a ideia de Ferro que os elementos históricos presentes em um filme devem ser efetivamente comprovados pela supervisão de um historiador, com domínio inconteste do assunto e acesso aos recursos que lhe permitam fazer tal análise. Rosenstone, por sua vez, adota uma postura mais flexível com relação ao assunto, entendendo que não há como reconstituir um passado histórico de maneira fidedigna. Para ele há, na maioria das vezes, pouca documentação ou apenas registros esparsos. Rosenstone, portanto, trabalha no mundo das possibilidades e vê o cinema como um instrumento que cria uma perspectiva histórica aberta, no máximo releituras do nosso passado.

\subsection{CINEASTAS, ESTADO E POLÍTICAS DE CINEMA}

A Belle Époque do cinema brasileiro (1908 e 1911) é considerada a fase de ouro para a cinematografia do país. É uma época marcada pela produção artesanal e pela expressiva participação dos produtores brasileiros no mercado nacional. Seus filmes eram bem recebidos pelo público brasileiro, ainda não seduzido pelo filme estrangeiro, que ainda apresentava uma produção irregular, uma situação que só vai se alterar com a estruturação do mercado cinematográfico internacional, nos anos posteriores a $1^{\text {a }}$ Guerra Mundial, que propicia a monopolização desse mercado pelos norte-americanos.

Após o que a historiografia consagrou como a 'bela época' do cinema brasileiro, período compreendido entre 1908 e 1911, no qual alguns exibidores produziram filmes alavancando a produção nacional em termos quantitativos, temos o início da ocupação quase total do mercado brasileiro pelo produto estrangeiro. Com a I Guerra Mundial, a produção norte-americana açambarcou o mercado brasileiro, afastando suas principais concorrentes europeias - França, Itália e Dinamarca. Data daí o início da instalação das agências de distribuição das principais empresas produtoras norte-americanas - 
Fox, Paramount, MGM, etc. A produção no Brasil de filmes ficcionais - então denominados 'posados' - diminuiu consideravelmente e a qualidade era muito inferior quando comparada ao produto norteamericano. (SÁ NETO, 2008, p.1)

A partir de 1915, os filmes norte-americanos começam a chegar ao país e rapidamente ganham a aceitação do público brasileiro. Nessa época tem início uma associação entre os distribuidores americanos e os exibidores nacionais, e é também quando o cinema norte-americano passa a dominar o mercado nacional. A baixa capacidade financeira e a inferioridade técnica frente ao cinema americano restringiam a participação do cinema brasileiro no mercado interno.

Nesse mesmo período, no Brasil, já se via uma produção de filmes históricos, mas que tratavam de fatos e personagens da história de Portugal. Com a arrancada da produção cinematográfica paulista (1911-1919) é que começam a ser produzidos filmes históricos e de adaptação literária, com temática essencialmente brasileira. A produção desses filmes tinha uma característica bastante particular, pois eram realizados de maneira independente, por iniciativa dos próprios cineastas, uma constante que vai se repetir ao longo da história do cinema brasileiro.

Apesar da diversidade de temas, os filmes tinham algo em comum, retratavam histórias e personagens da vida nacional brasileira, sob uma perspectiva da exaltação nacional, como podemos observar pelos títulos: O Aleijadinho (1915), de Guelfo Andaló; Grito do Ipiranga ou Independência ou morte (1917), de Giorgio Lambertini; Heróis brasileiros na guerra do Paraguai (1917), de Achilles e Giorgio Lambertini; Tiradentes ou Mártir da Liberdade (1917), de Paulo Aliano; Tiradentes, Tiradentes (1917), de Perrace Felice; e Barão de Rio Branco (1918), de Antonio Serra, e eram, na sua maioria, realizados por imigrantes italianos que procuravam se integrar à cultura brasileira. (BERNARDET, 1982, p.57-58)

Também foram produzidos, nessa mesma época, filmes de adaptação de obras literárias, de autores nacionais. Em São Paulo, Antonio Campos e Vittorio Capellaro dirigem Inocência (1915), a partir do romance homônimo de Alfredo Taunay e O Guarani (1916), baseado em obra de José de Alencar; no Rio de Janeiro, o diretor Luis de Barros dirige três filmes adaptados da obra de José de Alencar, A Viuvinha (1915), Iracema (1918) e Ubirajara (1919).

A década de 1920 é marcada pelos Ciclos Regionais, época em a produção cinematográfica acontecia em diferentes cidades do país, mesmo enfrentado enormes dificuldades, tanto de produção, quanto de distribuição. Entre os anos de 1924 e 1930, uma grande campanha em defesa do cinema brasileiro, liderada por Pedro 
Lima e Ademar Gonzaga e encampada pelas revistas Cinearte, Selecta e Paratodos, vai envolver grande parte dos profissionais da área.

No início da década de 1930 acontece mais uma tentativa de industrialização do cinema nacional, empreendida pela Cinédia e pela Brasil Vita Filmes, mas que fracassa em pouco tempo, sem ter conseguido resolver os problemas relativos à área cinematográfica, como a falta de recursos para investir nas produções, a inexistência de ações de proteção do Estado e o domínio norte-americano nas salas de exibição.

Em 1930 Vargas assume o poder e, assim, tem início um processo de modernização e de integração política do país. Esse governo vai conferir uma atenção especial para a área cultural, que iria ter uma participação ativa na construção de um sentido de nação e de identidade nacional e adotar uma atitude mais conciliadora na área cinematográfica e, a fim de evitar conflitos com os cineastas e com a ACPB, vai oferecer algumas concessões. Uma delas foi criar a primeira forma de estímulo ao cinema educativo, através do Decreto-lei n. 21.240/1932, marcando o início para o estabelecimento e o desenvolvimento de uma futura política para 0 setor cinematográfico, com destaque para a instituição da taxa cinematográfica para a educação popular, um valor a ser descontado dos produtores e dos exibidores quando da exibição de filmes nas salas de cinema.

A intervenção do novo governo ocorreu no plano da produção, distribuição, importação e exibição e, consequentemente, o cinema deixava de ser uma atividade regulada apenas pelas leis do mercado. O Estado passou a regular a atividade, atendendo a reivindicações dos diversos setores, agora organizados em entidades corporativas, e projetando-se como o árbitro acima dos interesses particularistas. A relação entre estas entidades, que compreendiam desde educadores até produtores, com autoridades federais, era direta. (SIMIS, 1996, p.92-93)

Uma outra iniciativa desse governo que merece destaque, foi a criação do Convênio Cinematográfico, uma iniciativa de apoio ao filme educativo, com objetivo de estimular a produção e a veiculação quinzenal de filmes infantis, que deveriam ser incluídos, de maneira obrigatória, antes ou no final do filme principal a ser exibido. (SIMIS, 1996, p.36-37)

Em 1934, o governo edita, então, o Decreto-lei n. 24.651, de apoio e de estímulo à produção e exibição de filmes educativos, documentários, cinejornais e curtas metragens. Contudo, o único resultado prático obtido foi o aumento efetivo da produção do filme educativo, sem atingir, no entanto, o filme comercial. 
O Estado Novo também empreendeu uma profunda reforma educacional, acompanhada de uma política cultural que visava, sobretudo, promover os valores cívicos e resgatar e a identidade nacional, um objetivo bem definido dentro de um quadro ações orientado à construção de um projeto político, econômico e social para a nação.

Dentro dessa política de estímulo ao nacionalismo, o Estado vai criar o INCE, um órgão voltado ao estímulo do cinema educativo, uma antiga reivindicação dos educadores Jonathas Serrano e Francisco Venancio Filho e do cineasta e roteirista Joaquim Canuto Mendes de Almeida. O INCE promoveu, entre outras coisas, a exibição de filmes em mais de mil escolas e institutos de cultura, além de ter organizado uma filmoteca, realizado inúmeros documentários e também formado um acervo audiovisual relevante, com registro das mais variadas manifestações populares e do patrimônio histórico e artístico nacional.

Dentre as diversas ações realizadas pelo Estado, voltadas à área cultural e artística, visando a valorização da nossa identidade nacional, a constituição de um sentido de nação e a formação de um sentimento de nacionalismo, podemos citar o projeto do Canto Orfeônico (canções patrióticas para as escolas e para ocasiões cívicas), de Heitor Villa-Lobos.

O governo Vargas também agiu no sentido de promover o filme histórico, produzindo o filme O Descobrimento do Brasil (1936), dirigido por Humberto Mauro, uma coprodução do INCE, em parceria com o Instituto do Cacau da Bahia, um trabalho que demandou uma minuciosa pesquisa histórica para reconstituir os fatos relatados na carta de Pero Vaz de Caminha, escrita quando da chegada da esquadra portuguesa à costa brasileira, em 1500. O filme permaneceu poucas semanas nas salas de cinema devido ao pouco interesse do público.

Vargas vai conduzir uma política para o cinema que atuava em dois campos de ação: reconhecia a realidade do livre comércio, ou seja, a livre circulação do produto estrangeiro no território nacional, notadamente do filme comercial norte-americano que já dominava todas as salas de cinema, ao mesmo em tempo que apoiava a difusão do cinema educativo, dos cinejornais e dos documentários, sem, no entanto, gerar conflitos com o mercado, com os exibidores e principalmente com os distribuidores de filmes norte-americanos.

Em relação ao cinema nacional comercial, de longa metragem, o governo Vargas vai atuar ter atuação pontual, seja por meio de concessões à ACPB, seja com nova legislação, seja por conta da instituição do Convênio Educativo, que veio para mediar 
os conflitos existentes entre os produtores e os exibidores, que determinava a obrigatoriedade de exibição do filme brasileiro, estendida para todos os outros gêneros de curta metragem, estipulando a medição mínima de 100 metros lineares, trazendo um alento para os produtores nacionais, que se comprometeram a produzir 500 filmes ao ano.

Apesar disso, ainda havia uma dissociação entre o Estado Novo e a área cinematográfica, embora algumas medidas sinalizassem a intenção do governo de ajudar o setor. Dentre elas vemos o Decreto-lei n. 1949 de 1939, que definia a reserva de mercado para o filme nacional, por meio da obrigatoriedade da exibição de um filme de curta metragem, "em todo programa cinematográfico" (CATANI, 1987: 284) e o Decreto-lei n. 4064 de 1942, que cria o Conselho Nacional de Cinematografia, que dava representatividade ao setor cinematográfico (produtores, exibidores, distribuidores e importadores), com atribuições de promover, regular e fiscalizar a produção, a circulação, a propaganda e a exibição do filme brasileiro, em todo território nacional.

Pode-se considerar que o Estado brasileiro buscou dar seu apoio, desde início da década de 30 , à produção e à difusão do filme educativo e de curta metragem e, no período do Estado Novo, também ao filme histórico, sem, no entanto, ter uma política definida de apoio ao filme de longa metragem nacional, ficando apenas nas ações pontuais, mesmo considerando a existência de uma legislação de reserva de mercado, que na prática se mostraram insuficientes para resolver os problemas do setor. Porém, mesmo pequenas, essas concessões vão incomodar o cinema norteamericano, que dominava as salas de exibição desde 1915, e aumentar a preocupação do governo brasileiro, lembrando que, naquela época, os Estados Unidos eram um dos nossos principais parceiros comerciais. Essa dependência fica evidente pela aceitação, por parte do nosso governo, da redução das taxas alfandegárias para a importação do filme impresso, prevista no Tratado de Comércio, de 1935, assinado entre os dois países.

Definitivamente, consideramos que o filme nacional comercial de longa metragem não fazia parte dos projetos do Estado Novo e o seu estímulo seria um ponto de conflito e de possível desestabilização comercial, já que o Brasil dependia da exportação do café e os Estados Unidos eram nosso principal comprador.

A queda do Estado Novo em 1945 e a extinção do DIP interrompem um projeto de instrumentalização do cinema brasileiro para fins de propaganda das ações de um regime e divulgação de seu líder. Na década de 1940 a produção de filme histórico 
fica restrita a poucos filmes, como o Inconfidência Mineira (1946), de Carmen Santos, uma produção com forte viés nacionalista, que demorou dez anos para ser concluída. O término do Estado Novo culminou com a redemocratização do país e com o desmantelamento de parte da estrutura intervencionista existente no Estado Novo.

Já o governo de Eurico Gaspar Dutra (1946-1951) vai agir timidamente em prol do setor cinematográfico. Assina o Decreto-lei n. 20.493 de 1946, que definia que os cinemas lançadores eram obrigados a "exibir, anualmente, três filmes nacionais de entrechos e de longa metragem, considerados de boa qualidade", que representava um aumento significativo em relação ao decreto de 1939, mas que também se mostrava uma medida paliativa, pois não tocava na questão do estímulo à produção do filme nacional de longa metragem, que deveria ser pensada como uma política de Estado. Por outro lado, a Lei n. 790, de agosto de 1949, que concedia isenção de direitos e taxas aduaneiras, durante um período de cinco anos, para a importação de material destinado à indústria cinematográfica nacional, foi uma iniciativa importante desse governo, que favoreceu os estúdios paulistas no início da década de 1950. (CATANI, 1987, p.284-285)

O segundo governo de Vargas, de curta duração, foi marcado por uma profunda movimentação no setor cinematográfico, iniciada pela implementação do Decreto-lei n. 30.179, conhecido como a "Lei 8x1", que alterava a obrigatoriedade dos dias de exibição e que estabelecia uma reserva de mercado relativa à presença do filme brasileiro nas salas de cinema. A lei apresentava, no tocante ao aspecto da reserva de mercado, um aspecto questionável, como apontavam Flávio Tambellini e JeanClaude Bernardet, pois condicionava o limite do número de filmes nacionais a serem exibidos ao número de entrada no país de filmes importados, ou seja, a lei, ao procurar "proteger" o cinema nacional, acabava por restringir ainda mais a produção - e exibição - do filme nacional.

Se, em plena vigência da lei dos oito por um, se importassem oitocentos filmes, a produção local deveria ser de cem; por outro lado, se se importassem apenas 80 , a produção brasileira a ser exibida não poderia ultrapassar a casa das 10 películas. (CATANI, 1987, p.285).

Getúlio Vargas encomenda a Alberto Cavalcanti que ele encabece a formulação de um anteprojeto para a criação de um órgão voltado para a defesa da atividade cinematográfica, o INC. Para isso é composta uma comissão que vai ter como relatores, Décio Vieira Otoni, Jurandyr Noronha e José Sanz, sendo este último o 
responsável por elaborar o Relatório geral do cinema nacional, que foi estruturado em quatro partes: Estrutura do cinema brasileiro, Cinema oficial, Instituto Nacional de Cinema e Anexos.

Sá Neto $(2004$, p.93) faz uma análise desse relatório, concluindo que o mesmo se mostrava decepcionante em vários aspectos, com algumas análises feitas sob uma perspectiva reducionista como, por exemplo, a necessidade da presença do Estado frente à influência desagregadora dos filmes estrangeiros e à evasão de divisas estrangeiras. O relatório descrevia o funcionamento da produção do cinema nacional e chamava a atenção o fato de que o mercado exibidor brasileiro tenha sido moldado pelo filme estrangeiro, em razão da verticalização cinematográfica praticada pelo cinema norte-americano. O relatório também se referia a um levantamento efetuado pelo governo, de todos os órgãos que, de alguma maneira, desenvolviam atividades relacionados com o cinema, que apontava para a necessidade de haver uma maior centralização das atividades do setor. (SÁ NETO, 2004, p.93)

Isso se reflete na proposta, apresentada no relatório em capítulo relativo ao INC, de se criar um órgão voltado a resolver os problemas da indústria cinematográfica brasileira, proposta que incluía a criação de uma legislação protecionista, de uma preocupação com o documentário e uma análise da importância do UK General Post Office Film-Unity $(\mathrm{GPO})^{43}$ para o cinema contemporâneo. Uma conclusão importante da comissão, registrada no relatório, foi a de que o cinema brasileiro não era, de fato, uma indústria, e que os dois estúdios, Vera Cruz e Maristela, apresentaram uma vida vegetativa e, a Cinédia, era a única empresa interessada no desenvolvimento artístico da cinematografia nacional. (SÁ NETO, 2004, p.94)

$\mathrm{O}$ anteprojeto do INC apresentava uma visão pautada na qualidade artística como condição do desenvolvimento do setor, desconsiderando as questões econômicas e de mercado inerentes ao processo cinematográfico. Outra consideração a respeito do assunto é que, a questão estética, talvez influenciada por uma visão europeia, fruto da experiência de Alberto Cavalcanti no exterior, tem ênfase no gênero documental, e a importância dada ao GPO, em que pese a relevância deste órgão, é limitada pelo fato de ele ter sido o único modelo considerado. Outro ponto a ponderar é que o anteprojeto do INC não considerou a crise que se abatia sobre as companhias cinematográficas paulistas, uma situação que já indicava a necessidade de se fazer um estudo aprofundado e ampliado do setor, que poderia indicar uma

43 Órgão oficial inglês responsável pela realização de documentários, do qual Alberto Cavalcanti foi um dos nomes mais destacado. (SÁ NETO, 2004, p.94) 
saída para resolver tal crise.

A partir dos anos 1950, o Brasil vai presenciar uma fase de efervescência cultural. O capital da burguesia paulista vai permitir o surgimento de três importantes empresas, Vera Cruz, Maristela e Multifilmes, vai colaborar para a realização dos Congressos de Cinema Paulista e do Cinema Brasileiro, do I Congresso Nacional de Cinema Brasileiro (1952) e do II Congresso Nacional do Cinema Brasileiro (1953), que eram resultado direto da mobilização da classe cinematográfica nacional. A realização desses congressos permitiu que fossem criadas comissões, nos níveis municipal, estadual e federal, destinadas a fazer um diagnóstico da situação dramática que se encontravam, já por volta de 1953, as quatro empresas produtoras paulistas (Vera Cruz, Multifilmes, Maristela e Kino Filmes), por conta do elevado custo da produção dos seus filmes e do baixo retorno obtido nas bilheterias. (CATANI, 1987, p.286)

A crise do cinema paulista de 1953, na verdade, foi um indicador de que o país não apresentava condições para se constituir como uma indústria do cinema, por não possuir um projeto cultural para o setor cinematográfico, e nem algo parecido com o que foi feito por Getúlio Vargas no Estado Novo.

O importante a destacar aqui é o resultado do trabalho da Comissão Municipal de São Paulo, constituída em 1955, que apresenta seu relatório 'Situação Econômica e Financeira do Cinema Nacional' que expõe, pela primeira vez, um quadro claro da real situação do cinema brasileiro, defendendo a idéia de que "Cinema é problema de governo".

É bom que se entenda que tal relatório estava em sintonia com o clima de desenvolvimentismo do período, portanto, vai indicar a adoção de medidas de caráter comercial para o cinema brasileiro, entre elas, o reajuste dos preços dos ingressos, a limitação da importação, o auxílio financeiro através de linhas de crédito concedidas por bancos oficiais e também a instituição de uma premiação municipal para os filmes produzidos. Na visão desenvolvimentista, o cinema deveria ser entendido como uma atividade privada, portanto, caberia ao Estado apenas agir no sentido de estabelecer condições protetoras para o seu desenvolvimento. (RAMOS, 1983, p.18, 20)

Ramos destaca que as conclusões obtidas a partir do trabalho dessas comissões, vão embasar ações adotadas posteriormente, tais como, o estabelecimento de limites à importação de filmes estrangeiros, a concessão de subsídios para a implantação de uma fábrica de filmes virgens no país e para a criação de um banco de crédito e financiamento para filmes nacionais e a introdução de restrições à 
remessa de rendas de filmes estrangeiros para o exterior.

Um desdobramento dos trabalhos da Comissão Estadual de Cinema foi a criação, em 1956, no governo JK, da CFC que, dois anos depois, em 1958, viria se transformar no GEIC. Vinculado ao MEC, o GEIC não apresenta ações eficazes, como seria de se esperar de um órgão responsável pela implementação de uma indústria cinematográfica, e também não consegue articular-se a uma estratégia cultural do governo. (RAMOS, 1983, p.25)

As recomendações do GEIC, que refletiam as reivindicações encaminhadas pelos diferentes grupos pertencentes ao campo cinematográfico, consideravam que o governo deveria adotar medidas protecionistas, em prol do desenvolvimento do cinema brasileiro. Esse posicionamento vai causar um desgaste político para o governo, pois o colocaria em rota de colisão com os interesses das distribuidoras de filmes norte-americanos, aqui instaladas, principalmente num momento de internacionalização da economia brasileira e de dependência do país, cada vez mais crescente, de capitais externos para conduzir seu processo de industrialização. Novamente, vemos o Estado brasileiro se relacionar com a área cinematográfica brasileira de uma maneira bem tímida, oferecendo concessões de caráter limitado e apoio e uma legislação com viés protecionista, que indicavam a falta de uma política mais clara para o cinema nacional.

Em meados dos anos 1950, as divergências em torno de uma proposta de industrialização, motivam a formação de dois grupos, com visões distintas sobre o cinema nacional: um industrialista-universalista, baseado em uma perspectiva de associação ao capital estrangeiro, e outro, nacionalista, que defendia medidas que protegessem e conduzissem o processo de industrialização do cinema nacional.

O grupo industrialista-universalista, ligado ao grupo paulista, desenvolvia um excelente trabalho, que subsidiava as comissões de cinema e reconhecia a capitulação do Estado frente ao grande capital internacional, que lhe permitiu construir uma reputação positiva, por conta de sua competência técnica, o que lhe permite uma maior aproximação o Estado. Ao grupo nacionalista, de ação política limitada, restava somente a aproximação com o setor capitalista nacional e a manutenção de sua independência cultural no terreno cinematográfico, responsável por construir as bases para o surgimento de um "cinema independente", o Cinema Novo. (RAMOS, 1983, p.28)

E, assim, aos poucos o grupo paulista vai aumentar sua ascensão dentro da estrutura do Estado, até que passa a ocupar um espaço privilegiado a partir da 
criação do Geicine. Diferente do CFC e do GEIC, que eram órgãos consultivos e de estudos, portanto, de ação limitada, o Geicine vai assumir uma posição de articulador da questão cinematográfica junto aos órgãos governamentais, e até mesmo junto às Carteiras de Crédito e de Comércio Exterior. (RAMOS, 1983, p.29)

O Geicine surge em meio a um cenário de grande instabilidade política, contudo, suas ações são claras no sentido de incluir o cinema na esfera dos problemas econômicos do Estado. Talvez, por este motivo, é que o Geicine tenha sido incorporado, mais à frente, pelo Ministério da Indústria e Comércio, trazendo uma mudança de status para o cinema brasileiro, que passa a fazer parte dos assuntos de maior relevância dentro do Estado brasileiro.

Flávio Tambellini via a necessidade de o cinema brasileiro se encaminhar para um processo de industrialização, pois, segundo ele, nenhum cinema no mundo sobreviveria se não houvesse uma associação entre produtor e exibidor. Esta visão vai levar Tambellini a efetivar, quando à frente do Geicine, duas importantes medidas, voltadas à promover a aproximação entre o produtor nacional e o setor exibidor/distribuidor, dominado pelo capital estrangeiro, sendo muito criticado por isto. A primeira, que não alcançou êxito, foi a introdução da "distribuição compulsória", que obrigava as empresas distribuidoras aqui instaladas, a incluir, na sua programação, um filme nacional para cada dez filmes estrangeiros. Seu fracasso deveu-se a um erro de avaliação na sua concepção, por acreditar que essa medida poderia induzir o distribuidor a produzir filmes, apesar do volume de filmes importados que entrava no país. A segunda medida partia de uma estratégia de se vincular a importação de filmes à produção, na forma da Lei da Remessa de Lucros de 1962 (40\% de desconto do imposto de renda sobre a remessa de lucro para o exterior, dos rendimentos dos filmes estrangeiros, que poderiam ser aplicados na produção de filmes nacionais), porém, o seu caráter facultativo, fez diminuir o interesse das distribuidoras estrangeiras, tanto que foram produzidos apenas sete filmes no período. (RAMOS, 1983, p.30).

É inegável a importância dos trabalhos desenvolvidos pelas diferentes comissões de cinema, no que concerne à consulta e à proposições de soluções para a nossa cinematografia, que em muito contribuíram para delinear um quadro geral do cinema brasileiro e para apontar medidas a serem adotadas por parte do Estado. O Geicine, com status jurídico superior às comissões e ao GEIC e de ação limitada pelo seu papel de órgão executivo, vai tentar implantar uma política cinematográfica, pragmática e industrialista, que resulta em uma legislação básica para o setor 
cinematográfico. Segundo Ramos, mesmo com a ênfase industrialista de suas propostas, GEIC, Geicine e CAIC “...não conseguem engajar e sensibilizar o Estado para uma efetiva ação de organização e apoio ao campo cinematográfico". (RAMOS, 1983, p.32-33)

Embora não tenha contribuído para atenuar a fraqueza estrutural do cinema nacional, o Geicine teve o mérito de levar os problemas do cinema nacional para a órbita do Estado. É emblemática a posição de alguns membros do Cinema Novo, como Gustavo Dahl, Carlos Diegues e Maurice Capovilla, sobre o trabalho desenvolvido pelo Geicine, que viam nele uma tendência a obter o desenvolvimento do cinema "a qualquer preço", no sentido da busca de uma associação do capital externo à produção brasileira. Por outro lado, eles também reconheciam como positivas algumas ações do governo em benefício da indústria cinematográfica brasileira, como a proposta inédita de Dahl de trazer, para o mundo do cinema, a lógica da industrialização, pois, segundo ele, havia uma necessidade efetiva de uma indústria para o cinema, sob pena de a atividade se extinguir. (SÁ NETO, 2004, p.109,114)

A partir de 1966, o cinema brasileiro passa a fazer parte de um projeto cultural mais amplo, e essa inserção vai contribuir para a criação de um órgão investido de poder e com plena autonomia para executar uma política de proteção à cinematografia brasileira, de financiamento da produção, de regulação do mercado e de difusão do nosso cinema nacional, INC. Portanto, o instituto surge na esteira de uma ação mais ampla do Estado, que então decide enfrentar a questão cultural, até então relegada a segundo plano. Assim, se no governo JK e nos governos que antecederam o golpe, a presença do Estado no campo cultural era tímida e negligente, no governo de Castelo Branco essa situação vai ganhar outra configuração.

A presença de Flávio Tambellini na direção do INC, entre 1966 e 1967, vai diminuir o espaço político do grupo nacionalista nas discussões sobre o setor, embora, há que se reconhecer, que este grupo ainda mantinha resguardado seu espaço no campo da discussão cultural, ainda sob a influência da esquerda, e ainda contava com a atenção de determinados segmentos sociais.

Afastados da esfera estatal do cinema nacional, que estava sob articulação e influência do grupo universalista-industrialista, os cineastas do Cinema Novo continuavam reconhecendo no Estado a atribuição e a responsabilidade pelo desenvolvimento do cinema brasileiro e pela afirmação da cultura nacional, e mesmo no auge da euforia da democracia populista, mantinham a concepção de que o 
cinema deveria ser "produto de governo". Finalmente, órfãos da burguesia e do Estado populista, os cinemanovistas vão depositar suas últimas crenças e esperanças ideológicas num Estado neutro, que desempenharia um papel desinteressado na defesa do cinema nacional, desconsiderando a impossibilidade de haver neutralidade dentro do Estado, tendo em vista a presença de representantes de diferentes segmentos sociais que, para atender seus interesses e objetivos, acabavam por imprimir suas ideologias na forma de gestão do aparelho estatal. (RAMOS, 1983, p.55)

Concomitantemente ao trabalho do INC, começa a ser gestado um projeto para a criação de uma empresa estatal, de economia mista, para divulgar o cinema brasileiro. Jarbas Passarinho (1969-1974), à frente do antigo MEC, passa a adotar, a partir das concepções da ESG, uma postura de guardião do caráter nacional, no sentido da construção de um país e de uma integração cultural, baseada na ideia de harmonização social.

Entre os anos 1910 e 1970, vemos uma produção irregular de filmes históricos e, que abordavam a nossa história por meio de ações e figuras 'heróicas', sempre do ponto de vista da classe dominante, procurando mostrar seu lado generoso e seu interesse pelas questões sociais.

$\mathrm{Na}$ década de 1950, a questão do caráter nacional e popular era um tema sempre nas discussões culturais, tanto, que o cineasta Nelson Pereira dos Santos chega a afirmar que as principais fontes para o cinema nacional seriam a literatura, o folclore e a História do Brasil, recomendando o desenvolvimento de temáticas, mesmo que já anteriormente exploradas, como a Abolição da Escravatura e a Inconfidência Mineira e, também, a adaptação de obras literárias, de autores brasileiros, como pode ser visto no filme Sinhá Moça (1953), da Vera Cruz. (BERNARDET, 1982, p.58)

\subsection{GESTÃO PASSARINHO: ENSAIO DE UMA POLÍTICA PARA O CINEMA NACIONAL}

Superado o período de maior censura, que se inicia depois de 1968, com o Al-5, e o auge da repressão política, Jarbas Passarinho vai retomar uma das principais bandeiras do Cinema Novo: a implantação de uma indústria nacional de cinema, no 
intuito de imprimir uma nova dinâmica na condução do INC e da Embrafilme, uma iniciativa que se mostrará positiva, na medida em que vai dar início a uma fase áurea na relação do Estado com o cinema brasileiro, que vai de 1974 a 1978.

Jarbas Passarinho assumir o MEC num cenário de dirigismo cultural praticado pelo Estado, iniciado no ano de 1966, que pode ser identificado através de algumas de suas ações, como, por exemplo, a criação do INC e do aproveitamento do grupo universalista nos quadros de gestão desse órgão, para desenvolver um trabalho de planejamento das ações do Instituto, inclusive da concessão de financiamentos, de modo a conduzir a produção cinematográfica sob uma perspectiva comercial, almejando formação de uma indústria cinematográfica no país. É possível, assim, observar, uma nova orientação política do INC no que se refere à análise dos projetos, que passam a ser escolhidos, a partir de critérios que levam em conta a viabilidade econômica dos filmes, ou seja, uma diretriz que colocava ênfase no mercado, e, claro, na conquista e ampliação do público.

Vemos, no início dos anos 1970, indicativos de uma nova perspectiva para o cinema nacional, com a adoção de uma política de apoio e estímulo à produção, de caráter comercial, e também de apoio à produção de comédias eróticas, de filmes históricos e de adaptação de obras literárias.

A condução do INC, por pessoas ligadas ao grupo universalista, liderado por Flávio Tambellini, revela o desagrado dos setores militares com a produção do Cinema Novo, pela sua temática social e de esquerda, que the dava grande visibilidade no exterior. Por esta e outras razões, o regime via a necessidade de assumir a condução do processo cultural, particularmente do cinema, controle que vai estar presente na forma centralizada de seleção de projetos e de concessão de financiamento. Havia, portanto, um certo empenho do Estado, via INC/Embrafilme, em buscar a construção e o desenvolvimento de uma política cinematográfica, que fosse capaz de imprimir um caráter industrial ao cinema nacional.

O período também foi marcado pela ambiguidade, pois, se por um lado, havia o apoio a um cinema mais comercial, valorizando a produção nacional considerada popular, ilustrada pela pornochanchada, um gênero controverso e que recebia muitas críticas da classe média, por outro, havia também o apoio ao filme culto, que pode ser ilustrado pelo filme Toda nudez será castigada (1973), de Arnaldo Jabor.

Certamente que essa situação evidencia a existência de uma contradição no interior de um Estado que pretendia implantar seu projeto cultural, com o intuito de, na sua ótica, "melhorar" a formação da sociedade brasileira. Mesmo com incoerências, as 
mudanças observadas determinaram mudanças na forma como o próximo governo vai conduzir suas políticas voltadas ao financiamento cinematográfico, na gestão de Roberto Farias à frente da Embrafilme. (RAMOS, 1983, p.99)

\begin{abstract}
Assim, da parte da direção do INC e Embrafilme, não se nota qualquer preocupação em ocultar que o eixo principal era a ênfase comercialmente - industrial, defendendo-se uma produção indiscriminada que absorvia inclusive os filmes "eróticos". Em contrapartida, a produção "cultural" servia de anteparo às críticas quanto a esta ação da Embrafilme, bem como uma forma de estabelecer diálogo, de procurar atrair os setores remanescentes do nacionalismo dos anos 60 para um projeto agora capitaneado pelo estado. (RAMOS, 1983, p.98)
\end{abstract}

A questão relativa à produção do filme histórico e do filme de adaptação de obras literárias deve ser analisada dentro de um contexto mais amplo, de crescimento expressivo do mercado para o filme brasileiro, não por conta das produções financiadas pelos INC, mas pelo avanço da comédia erótica, que vai conquistar, a partir dos anos 1970, uma fatia cada vez maior do mercado de exibição brasileiro dominado pelo filme norte-americano -, e um público composto por segmentos mais populares.

É importante que se diga que a política de concessão sem restrições de financiamento cinematográfico, operava desde os primeiros anos da década de 1970, e que procurava sedimentar um caminho para a construção de uma indústria cinematográfica nacional, já mostrava sinais de desgaste, como aponta Bernardet:

O governo estava desgostoso com a pornochanchada, considerada vulgar, dando uma imagem "negativa" da sociedade brasileira. Por outro lado, todo o prestígio cultural-nacional e internacional conquistado pelo Cinema Novo estava periclitando e sem nenhuma perspectiva de reeguer-se, a não ser para um ou outro filme eventual, já que, por motivos políticos, o governo estava liquidando o Cinema Novo. Então, por um lado, a desprezada pornochanchada e, por outro, filmes prestigiosos, mas política e ideologicamente inaceitáveis. $E$ as comissões de seleção dos festivais internacionais vinham recusando filmes enviados pelo Brasil. Procurou-se então um cinema que pudesse ter um certo prestígio cultural, que se apresentasse com um verniz cultural, sem oferecer as inconveniências de um cinema crítico. A saída foram as adaptações literárias, que transfeririam para o cinema o status cultural das obras literárias originais. (2009, p.78-79)

De forma que a proposta inicial, colocada ainda na gestão de Jarbas Passarinho, de um apoio a adaptações de obras literárias para o cinema e também de estímulo à produção de filmes históricos, na avaliação de Bernardet, reforça a ideia da existência de um dirigismo, por parte do Estado, na política cultural, visto que o 
apoio à produção de filmes de adaptação de obras literárias pretendia recuperar a imagem do cinema nacional que, na visão do governo, havia sido maculada pela pornochanchada. Esse apoio era, enfim, uma estratégia para reposicionar a imagem do próprio Estado, que, ao apoiar a produção de conteúdos vinculados ao campo do culto, teria um maior reconhecimento social.

No período 1970-1971, por sugestão do Ministro Jarbas Passarinho, às vésperas das comemorações do Sesquicentenário da Independência do Brasil, o governo retoma a ideia de estimular a produção de filmes históricos, considerando que este tipo de produção seria uma forma de valorizar nosso passado, chegando até a indicar alguns temas como: a Força Expedicionária Brasileira $(\mathrm{FEB})^{44}$, o Correio Aéreo Nacional $(\mathrm{CAN})^{45}$, os bandeirantes, Borba Gato, Anhanguera e Paes Leme, e outras figuras de destaque nacional, como Osvaldo Cruz, Santos Dumont, Delmiro Gouveia, Duque de Caxias, entre outros, sugestões que não encontram muita receptividade no meios cinematograficos. (BERNARDET, 2009, p.79)

Aproveitando então o momento de comemoração, o experiente produtor Osvaldo Massaini realiza o filme Independência ou Morte (1972), dirigido por Carlos Coimbra, que foi um sucesso de público, e por isso mesmo vai ser prontamente encampado pelo governo militar. "As exortações ministeriais não surtem efeito: o filme histórico é dispendioso, não tem mercado assegurado. Difícil os produtores se lançarem em grandes orçamentos só para agradar ao ministro." (BERNARDET, 1982, p.60)

Como a exaltação à realização desses filmes não era um incentivo suficiente para convencer os produtores a bancarem sua realização, de custo elevado, o governo institui, em 1972, prêmio anual para filmes adaptados de obras literárias de autores mortos, uma iniciativa de incentivo à produção cinematográfica deste gênero. $\mathrm{Na}$ avaliação de Bernardet (2009, p.78), essa decisão de restringir as obras a autores mortos foi um "...desincentivo aos argumentos originais, que representam uma área importante da criação cinematográfica...", e, mesmo considerando que estes autores tenham sido alvo, no passado, de inúmeras adaptações, essa restrição não justifica como uma parte de uma política cultural.

Podemos entender, entretanto, que a decisão de limitar a escolha de obras de "autores mortos", seja uma maneira de valorização da identidade nacional, mas que dava ao Estado um certo controle sobre as obras a serem escolhidas (já publicadas),

\footnotetext{
44 Foi uma força militar brasileira que lutou, em fins de 1944, durante a II Guerra Mundial, na Itália, ao lado dos aliados. Sobre o assunto ver mais em: <http://www.portalfeb.com.br/armamento/feb-do-inicio-ao-fim>. Acesso em: 10/dez/2012.

45 Serviço postal militar brasileiro, instituído em 1931, que recebeu essa denominação em 1941, com a criação do Ministério da Aeronáutica. Disponível em <http://www.cecan.aer.mil.br/>. Acesso em 10/dez/2012.
} 
resguardando do Estado de possíveis escolhas de obras que lhe trouxessem críticas, e polemizassem assuntos atuais.

Em 1974 o cinema brasileiro já havia obtido algumas conquistas junto à esfera estatal, como a regulação referente à obrigatoriedade da exibição de filmes nacionais, indicando que havia o reconhecimento da importância de se manter uma reserva de mercado para o filme nacional. A proximidade da classe cinematográfica com diferentes órgãos vinculados à estrutura estatal, iniciada nas comissões de cinema (municipais, estaduais e federais) que encaminharam uma série de estudos sobre o mercado cinematográfico brasileiro, acabou por conseguir levar para o governo a visão do cinema brasileiro como sendo um assunto de Estado.

Esse entendimento se reveste da maior importância, pois amplia as possibilidades de ação dos segmentos ligados ao setor, no sentido de apresentar soluções e participar, em âmbito ministerial, na formulação de políticas, como aconteceu à época do GEIC e do Geicine, período de pequenas, mas importantes, conquistas relacionadas à legislação de proteção ao cinema nacional.

Nesse percurso, o trabalho do INC indica uma posição mais assertiva do Estado, no sentido de tentar impor uma política para o setor cinematográfico, que buscasse a industrialização do nosso cinema, sem conflitar com os interesses estrangeiros.

Outro ponto a destacar, é que as diretrizes sinalizadas por Jarbas Passarinho para o INC e a Embrafilme resultaram em melhorias da gestão desses órgãos e introduziu a prática da análise prévia da viabilidade econômica dos filmes, relativas à sua produção, em busca de uma ampliação do mercado.

\subsection{GESTÃO FARIAS: CAMINHOS PARA O FILME HISTÓRICO E O FILME DE ADAPTAÇÃO LITERÁRIA}

Ainda que o governo Médici seja um período marcado pelo "milagre econômico", mas também, e principalmente, pela sua característica autoritária, de abuso do poder, violência e tortura, foi uma época na qual os militares iniciam um tímido diálogo com o setor cultural, que se amplia com o governo Geisel, durante os anos de 1974-1979, e que vai se refletir na área cinematográfica, sendo vista como uma excelente fase na relação dos cineastas com o Estado, uma das marcas da gestão de Roberto Farias na Embrafilme. 


\begin{abstract}
A gestão Roberto Farias (1974/1979) se insere, por razões conjunturais, numa ótica de participação estatal junto à indústria cultural, incluída com relevância nos programas de ação governamental. O período é fertil em conquistas e o setor da atividade do cinema se impõe enquanto grupo de negociação que busca sua legitimidade junto ao governo e à opinião pública. E desta vez, e à diferença das outras, as demandas são acolhidas e abonadas por fartos recursos oficiais. (AMANCIO, 2000, p 56)
\end{abstract}

Portanto, podemos depreender que a condução da Embrafilme por Roberto Farias refletia a vontade do governo militar em aperfeiçoar os canais existentes de interlocução com a classe cinematográfica - e em abrir outros novos, um sentimento que era recíproco. Havia também uma convergência de objetivos, já que a proposta ideológica para o campo cultural, apresentada pelo regime, também entendia a importância de se estruturar o mercado interno, para o desenvolvimento da indústria cinematográfica nacional, uma das estratégias relevantes do projeto nacionalista dos militares (AMANCIO, 2000, p.41)

Assim, uma das bases de ação do governo Geisel, além de dar curso ao processo de modernização do país, foi coordenar a implantação de um projeto cultural de forte cunho nacionalista, que tinha suas diretrizes definidas na PNC, que trazia uma orientação um pouco abrangente para a área cinematográfica, que falava de apoio à "produção cinematográfica nacional" e de "tornar a produção melhor e mais competitiva", "dando-Ihe base artística". Pelo que o cinema representava para o projeto cultural do regime, vê-se que eram objetivos aparentemente modestos, vagos, repetindo objetivos que poderiam ser encontrados em qualquer projeto direcionado à área cinematográfica.

O mérito da gestão Farias foi dinamizar esse objetivo, ampliando a ação estatal e imprimindo maior eficiência ao controle do mercado cinematográfico, com o apoio do Ministro Ney Braga, que tinha bom trânsito junto aos órgãos da máquina estatal que lidavam diretamente com planejamento e com recursos da União. Ambos foram autores de inúmeras iniciativas voltadas à área cultural. (AMANCIO, 2000, p.39)

A gestão Farias também vai ter um papel importante no crescimento da produção nacional. Vemos, no período, uma produção significativa de filmes de adaptação de obra literária e a retomada de uma iniciativa de governo Médici, de estimular a produção de filmes históricos. Essa tentativa de reconstituição da história é, em parte, decorrente do período compreendido do Estado Novo, que já procurava resgatar e revalorizar fatos, heróis e eventos, para usá-los de acordo com os interesses daquele regime. 
A proposta da Embrafilme, que visava atender a um projeto mais amplo governamental, definia novas modalidades de produção para esses filmes: a Carteira de Coproduções de Filmes Históricos (1975) e o Programa especial de pesquisas de temas para filmes históricos (1977).

A Carteira de Coproduções de Filmes Históricos (1975) era destinada à diretores e/ou empresas produtoras de comprovada capacidade profissional, que deveriam cumprir, pelo menos, três, dos seguintes requisitos:

“...ter recebido prêmio de melhor filme ou melhor diretor em Festival
Nacional reconhecido pelo INC, ou prêmio de qualidade do mesmo
Instituto, ou em Festival Internacional. Contar com mais de 10 anos
de atividade profissional, ter sede própria, com equipamento e ter
produzido no mínimo três filmes de longa metragem nos últimos 10
anos. (AMANCIO, 2000 p.51)

A Embrafilme receberia verbas para tal fim, podendo ser coprodutora das obras, com um teto de investimento de $\operatorname{Cr} \$ 270.000$, até 1975, posteriormente ampliado para $\mathrm{Cr} \$ 1.500 .000,00$, sendo que metade desse valor seria referente como participação da empresa e, a outra metade, na forma de subvenção estatal. (BERNARDET, 1982, p.60)

A seleção dos projetos dos filmes históricos estava vinculada, inicialmente, ao DAC, e a Embrafilme atuava apenas como intermediária no processo.

Para tanto, se estabelece a criação de uma Comissão de Seleção Prévia junto ao DAC/MEC que selecionará os projetos, juntamente com aqueles de solicitantes que, não preenchendo pelo menos um dos requisitos acima citados, desejem também se beneficiar de recursos estatais. A Comissão é criada pela Portaria 49 do DAC, de $3 / 4 / 1975$, em data anterior à ata que a torna pública, fazendo-nos supor que esta antecipação coloca no Ministério a origem daquele programa, apenas intermediado pela EMBRAFILME... (AMANCIO, 2000, p.52)

A composição da comissão contava com representantes de diversos segmentos do setor estatal e da área cinematográfica: Antonio Carlos Fontoura (Sindicato Nacional da Indústria Cinematográfica); Arnaldo Jabor (Autores de Filmes); Joaquim da Costa Pinto Neto (Departamento de Assuntos Culturais do MEC); Octavio de Faria (Conselho Federal de Cultura); Leandro Tocantins (Embrafilme); Biazino Granato (Instituto Nacional de Cinema) e Marcelo Moreira de Ipanema (Instituto Histórico e Geográfico Brasileiro). (AMANCIO, 2000, p.52).

Mas os problemas não tardam a aparecer, pois o processo de seleção conduzido pelo DAC/MEC começava a gerar um conflito: a duplicidade na atribuição de seleção 
de filmes que seria atribuições da Embrafilme, como fica claro na entrevista de Farias, concedida a Tunico Amâncio:

\begin{abstract}
Eu, quando comecei a tomar ciência disto, falei para o ministro que não tinha sentido existir uma empresa distribuidora e produtora de filmes, que era a Embrafilme, e a Secretaria [sic] de Assuntos Culturais também estar fazendo filmes. [...] Eu comecei a puxar os recursos porventura existentes no DAC para a Embrafilme [...] E este movimento dentro do ministério não continuou. Acabou porque eu disse: não tem cabimento eu ficar trabalhando aqui e ficar um outro [trabalhando] lá. Talvez hoje, pensando melhor, isto pudesse significar uma coisa separada da Embrafilme para certo tipo de produção, o que poderia acontecer na Fundação [do Cinema Brasileiro]. (AMANCIO, 2000, p.53)
\end{abstract}

$\mathrm{Na}$ visão de Bernardet essa comissão do DAC/MEC configurava “...a burocracia cultural que seleciona e promove o que lhe interessa, e rejeita o resto". Ainda segundo o autor: "O filme histórico torna-se cada vez mais assunto de Estado, mas, mais uma vez, os resultados não foram brilhantes para a burocracia e o tiro saiu pela culatra." (1982, 60-61)

E essa visão talvez possa ser atestada pelo seguinte aspecto: aqueles projetos que não haviam preenchido os requisitos contidos nos editais da Embrafilme, receberiam uma segunda oportunidade dentro da estrutura estatal, através do próprio DAC e com recursos provenientes do MEC.

Depois de terminado o processo de seleção, dos 23 projetos inscritos, 21 eram de estreantes e dois históricos. Os aprovados, por unanimidade, na terceira reunião da Comissão, foram Anchieta, José do Brasil (histórico); Paraíso no Inferno; Solavanco Classe A, Mar de Rosas; Crueldade Mortal e Parada 88 e aqueles, também aprovados, mas não por unanimidade, mas pela maioria da comissão foram, Um Brasileiro Chamado Rosaflor, Na boca do Mundo, Um Mundo Visto e Sonhado e Nacional ou Estrangeiro (AMANCIO, 2000, p.53).

A outra modalidade criada na gestão Farias é o Programa Especial de Pesquisas de temas para filmes históricos (1977), que tinha como objetivo, nas palavras do próprio Roberto Farias, “...fazer projetos, inclusive com a possibilidade de rever a história, fazer investigações e apresentar uma linha diferente da história oficial", e recebia recursos provenientes do FNDE. (AMANCIO, 2000, p.87)

Dos 74 projetos apresentados, $18^{46}$ são selecionados, recebendo, cada um, uma

\footnotetext{
46 Esse número de selecionados, não considera o projeto Castro Alves, que, embora selecionado à título de coprodução, teve uma parte do orçamento a ele destinado, utilizada para a realização de testes técnicos, realizados em São Paulo e Los Angeles. (AMANCIO, 2000, p.90)
} 
verba no valor de $\mathrm{NCr} \$ 300.000,00$, condicionada à entrega, no prazo de quatro meses, de um projeto que incluísse a pesquisa histórica, um roteiro acompanhado de um amplo material, abrangendo desde a fotografia, figurino, elementos de pesquisa musical, orçamento detalhado, equipe técnica, documentação contábil, até a prestação de contas do investimento que a Embrafilme teria que fazer.

Dos 18 projetos selecionados, apenas dois conseguiram ultrapassar a etapa da pesquisa, Castro Alves e General Osório, mas nenhum deles chegou a ser realizado. No ano seguinte, em 1978, mais três projetos são aprovados, Casa Grande e Senzala, Profissão Culpado e Oswald de Andrade, este último de Joaquim Pedro de Andrade, o único a ser concluído, já na gestão de Celso Amorim (1979-1982) da Embrafilme, lançado nos cinemas com o título de O Homem do Pau Brasil (1981).

\begin{tabular}{|c|c|c|}
\hline Projetos selecionados & Ano & Produtora \\
\hline 30 anos de Amazônia & 77 & Beca Prod. Filmes Ltda. \\
\hline Agonia romântica & 77 & Melopéia Cinemat. \\
\hline Assalto, O & 77 & Lynkfilm S/A \\
\hline Castro Alves & 77 & NAU - Nac. Artistas Unidos \\
\hline General Osório & 77 & Vydia Prod. Cinemat. S.A. \\
\hline Incrível Maria Quitéria, A & 77 & José Pinto Prod. Ltda. \\
\hline I-Juca Pirama & 77 & Cinemática Prod. Cinemat. S/A \\
\hline José do Patrocínio & 77 & Misfilmes Prod. Cinemat. S/A \\
\hline Juventudo & 77 & CASB - Prod. Cinemat. Ltda. \\
\hline Pedro Álvares Cabral & 77 & Miguel Borges Prod. Cinemat. \\
\hline Plácido de Castro & 77 & L.M.Prod. Cinemat. Ltda. \\
\hline Retirada da laguna, $A$ & 77 & Regina Filmes Ltda. \\
\hline Rio dos sinos & 77 & Walter Hugo Khouri Cinemat. \\
\hline Rita Lobato & 77 & Kinoart Filmes Ltda. \\
\hline Santos Dumont & 77 & Argos Filmes Ltda. \\
\hline Tronco, O & 77 & Raiz Prod. Cinemat. Ltda. \\
\hline Vital Brasil & 77 & Procitel Prod. Cine Tel. \\
\hline Casa-grande e senzala & 78 & Nádia Filmes Ltda. \\
\hline Profissão culpado & 78 & Geraldo Veloso Prod. Cinemat. \\
\hline
\end{tabular}

Fonte: Artes e Manhas da Embrafilme - p.145

O projeto General Osório é um caso elucidativo dos labirintos e imposições que existiam dentro da estrutura do Estado, como, por exemplo, a pressão feita pelo vice-presidente, general Adalberto dos Santos Pereira, a pedido da sobrinha do general Osório, para que Roberto Farias intercedesse na aprovação do projeto, decisão que foi transferida para Ney Braga, livrando Farias e a Embrafilme dessa situação. (AMANCIO, 2000 p.88-89)

Apesar de as duas iniciativas da Embrafilme de estímulo ao setor cinematográfico, a 
Carteira de Coproduções de Filmes Históricos e o Programa Especial de Pesquisas de temas para filmes históricos, atenderem aos interesses do projeto cultural do governo Geisel, parece incompreensível que todo esse empenho tenha tido resultados práticos tão pouco expressivos.

Segundo Roberto Farias ${ }^{47}$, este programa de Pesquisas de temas para filmes históricos, não era, na verdade, parte de nenhuma política oficial de estímulo para a produção cinematográfica, mas somente uma estratégia adotada por ele, no sentido de obter mais recursos para Embrafilme.

Anchieta, José do Brasil (1977), de Paulo Cesar Sarraceni, foi um filme que teve um grande apoio do Estado, que esperava que ele fosse um marco para o filme histórico, nessa nova fase do cinema brasileiro, redundou num enorme fracasso, talvez resultado de uma sucessão de erros: produção tumultuada, desperdício de dinheiro público, que sem dúvida refletiu no trabalho e no péssimo resultado artístico e de bilheteria, que refletia a fragilidade artística do filme.

É importante destacar que no período de incentivo ao filme histórico, a Embrafilme suspendeu o financiamento à pornochanchada, em razão das pesadas críticas relativas à qualidade artística duvidosa deste tipo de produção, e também porque outros filmes financiados pela empresa vinham obtendo uma boa aceitação do público, como o A Estrela Sobe (1974), de Bruno Barreto e Xica da Silva (1976), de Cacá Diegues, uma das maiores bilheterias do cinema nacional, que vai ocupar o espaço da pornochanchada, em temos percentuais, no mercado cinematográfico nacional. (BERNARDET, 2009, p.80)

Dentro do projeto nacionalista, o filme histórico poderia cumprir um importante papel como instrumento de uma política cultural mais ampla, pois, esses filmes poderiam valorizar e recuperar a cultura nacional e o sentimento cívico, resgatar os heróis e fatos históricos, mas seus resultados, com exceções, decepcionaram por ficarem aquém dos resultados esperados pelo governo.

A contradição que envolve a iniciativa de estímulo ao filme histórico, está no fato de que os filmes produzidos no período de 1974-1978 se utilizaram dos canais tradicionais de financiamento da Embrafilme, não fazendo uso das iniciativas de incentivo ao filme histórico (Carteira de Coproduções de Filmes Históricos e o Programa Especial de Pesquisas de temas para filmes históricos), dos quais podemos citar: Xica da Silva (1976), de Carlos Diegues; Aleluia Gretchen (1976), de Sylvio Back; Ajuricaba (1977); Coronel Delmiro Gouveia (1978), de Geraldo Sarno e

47 Entrevista concedida a este pesquisador em 15 de janeiro de 2010, no Rio de Janeiro. 
A Batalha de Guararapes (1978), de Paulo Thiago.

Portanto, mesmo sendo produções de filmes históricos, nenhuma delas se utilizou dos canais de financiamento específico para esse gênero, o que nos leva a supor que foram realizados mais em razão de uma iniciativa pessoal de seus produtores/cineastas, com o intuito de obterem acesso ao financiamento da Embrafilme, do que em função do estímulo governamental para a produção de tais obras.

Segundo Bernardet:

\begin{abstract}
A maioria dos cineastas que mandaram projetos históricos não o fez, necessariamente, por simpatia pelo governo, nem por afinidades ideológicas, nem por comungar com uma visão da história, embora o simples fato de mandar projeto indique que não há incompatibilidade completa. É, para os cineastas, uma possibilidade de produzirem filmes - históricos ou não - ainda mais podendo se beneficiarem de subvenção, além de coprodução, e de terem financiamento para o roteiro, o que é excepcional na história do cinema brasileiro. Se o projeto lançado pelo governo fosse sobre zoologia ou esportes, grande parte dos produtores atenderia igualmente à solicitação. E nem o fato de lançar o projeto histórico, até mesmo com dois crivos, no argumento e no roteiro, assegura que os filmes sairão conforme a expectativa governamental. Anchieta que o diga. (1982, p.61-62)
\end{abstract}

Que continua:

Mas o fato de o governo não assumir diretamente a produção, nem oficializar suas expectativas, dá ao sistema uma margem de elasticidade em que tanto o governo, como os cineastas, defendem os seus interesses. Essa forma de procedimento não é evidentemente um grande risco para o governo. A elasticidade tem cartas marcadas, visto que o diálogo não se dá de igual para igual. $\mathrm{O}$ governo sabe que os cineastas precisam fazer filmes e, implicitamente, na média, acabaram respeitando as determinações. Para qualquer excesso, o mecanismo cinematográfico dispõe de controles e o governo, de meios de repressão. $E$ também porque, em matéria de filmes históricos, o governo não está pedindo nada demais. (BERNARDET, 1982, p.62)

Se para os filmes históricos tivemos ações efetivas de apoio do governo Geisel, por meio da Embrafilme, o mesmo não podemos dizer dos filmes de adaptação de obras literárias. Nem mesmo uma premiação instituída no governo Médici, o Prêmio Embrafilme, voltada a esse gênero de filme, teve continuidade na gestão Farias, que só sugeriu a mudança no nome do prêmio para Jarbas Passarinho. Uma iniciativa de incentivo que se perdeu.

Mesmo sem um receber apoio específico, alguns filmes relativos ao período, como, A estrela sobe (1974), de Bruno Barreto; A dama do lotação (1975), de Neville 
d'Almeida; Lição de amor (1975), de Eduardo Escorel e Lúcio Flávio, o passageiro da agonia (1977), de Hector Babenco encontraram um bom êxito em termos de bilheteria, e outros encontraram boa receptividade junto ao público.

Roberto Farias $^{48}$ afirma que não havia uma política de estímulo ao filme de adaptação de obras literárias e a seleção dos projetos atendia apenas a critérios técnicos, sem serem impostas restrições de qualquer tipo. Mesmo assim, foram realizados 31 filmes no período de sua gestão, que utilizaram os mecanismos tradicionais de financiamento da Embrafilme e o apoio dado da boa estrutura da Embrafilme distribuidora.

48 Entrevista concedida a este pesquisador em 15 de janeiro de 2010, no Rio de Janeiro. 


\section{CONCLUSÃO}

A sociedade brasileira passa por uma grande transformação nos anos 1950 e 1960, que se reflete no plano político, econômico e cultural. Contudo, o golpe de 1964 e a ascensão do grupo militar ao poder, provoca uma mudança no eixo ideológico do governo, alterando profundamente a condução da sociedade brasileira.

O golpe militar, por sua vez, colocou a esquerda num processo de formação de uma consciência social, de combate ao regime, sendo uma época de grande agitação política, crescimento da atividade cultural, mudança de costumes, e o surgimento de um ideal de revolução, visando subverter as estruturas da sociedade. Mesmo depois da instituição do Al-5 (1968) e da radicalização política e da censura, e o consequente afastamento da sociedade civil, governo vai buscar formas de se legitimar no poder.

O Governo Castelo Branco, pautado pela Doutrina da ESG, vai implementar mudanças nas diretrizes do plano cultural, através da atuação do CFC, voltadas a construir uma matriz ideológica para a cultura, que contemplava a questão da nacionalidade, da identidade cultural e da revalorização da nossa história.

Ainda que o governo Médici seja um período difícil e marcado pela ênfase no crescimento econômico e combate à luta armada, por outro lado, vemos o seu Ministro da Educação e Cultura, Jarbas Passarinho, adotar uma estratégia inovadora no campo cultural, se apropriando do discurso nacionalista, no qual a cultura deveria ser um instrumento para repensar e afirmar a identidade e a imagem do país.

No que diz respeito ao cinema nacional, vamos notar, nesse mesmo governo, um estímulo quase que irrestrito, à produção cinematográfica, de caráter comercial, que incluía até mesmo a comédia erótica. Esse governo vai dar importantes passos no sentido do desenvolvimento de uma indústria para o cinema nacional, que passava pelo estabelecimento de novas diretrizes, entre elas a reformulação e a mudança na forma de gestão, dos órgãos do setor, como o INC e a Embrafilme.

Sentindo em pouco tempo os reflexos negativos de sua opção e, por conta das críticas vindas de certos segmentos sociais, particularmente da classe média, que considerava essas comédias eróticas, vulgares demais. O Estado vai, então buscar, através da política de estímulo à produção de filmes decorrentes de adaptação de obras literárias e da criação de uma premiação para o gênero, o prestígio que a 
literatura detém perante a sociedade, ou nas palavras de Bernardet, passar a realizar agora um cinema que pudesse "...ter um certo prestígio cultural, que se apresentasse como um verniz cultural, sem oferecer as inconveniências de um cinema crítico. A saída foram as adaptações literárias, que transferiram para o cinema o status cultural das obras literárias." (2009, p.78-79)

Isto acaba por evidenciar uma ação do Estado marcada pela incoerência e ambiguidade, que estimulava a produção fílmica de maneira indiscriminada, permitindo que comédias eróticas ganhassem espaço, e que também, em contraposição a possíveis críticas, estimulava uma produção "cultural", como coloca Ramos (1983, p.98), que "servia de anteparo às críticas quanto a esta ação da Embrafilme, bem como uma forma de estabelecer diálogo, de procurar atrair os setores remanescentes do nacionalismo dos anos 60", para um projeto de Estado.

Às vésperas das comemorações do Sesquicentenário da Independência do Brasil (1972), é lançado o filme Independência ou Morte, que teve uma grande receptividade do público e de bilheteria, sendo 'exortado' pelo Ministro Passarinho como exemplo de filme histórico e encampado pelo governo militar. Contudo, o seu produtor buscou apoio do governo, sem receber retorno, o que parece indicar um deslocamento do discurso oficial, com relação ao divulgado incentivo à produção do filme histórico.

No governo Geisel, as ações para o campo cultural são norteadas pela PNC, que apresentava propostas e objetivos claros, depois de décadas de ausência de políticas públicas governamentais para o setor, que vão trazer importantes transformações para a área cinematográfica, como a reformulação do modelo de gestão da Embrafilme, que marca também uma aproximação do grupo do Cinema Novo com o governo, por conta da identificação de objetivos comuns, como a valorização da identidade nacional.

Para Geisel levar adiante a proposta de abertura política, ele inicia um processo de distensão, na busca de um maior diálogo com a sociedade e com a área cultural, incluindo o cinema, traduzida na tentativa de cooptar este último segmento para o projeto cultural governamental. Apesar da aparente concordância com as propostas contidas no projeto governamental, a atitude dos cineastas evidencia um pragmatismo dos mesmos para obter financiamentos para seus projetos.

Na gestão Farias, é retomada uma proposta do ex-Ministro Passarinho, de estímulo ao filme histórico, com a criação de uma Carteira de Coproduções de Filmes Históricos, sendo apresentados 23 projetos, dos quais apenas 5 foram realizados e 
do Programa especial de pesquisas de temas para filmes históricos que, de 74 projetos apresentados, apenas dois conseguiram ultrapassar a etapa de pesquisa, e nenhum deles chegou a ser realizado. No ano seguinte são aprovados mais três projeto, dos quais somente um foi aprovado, Oswald de Andrade concluído na gestão seguinte como o titulo de O Homem do Pau Brasil (1981) o que evidencia um resultado melancólico.

Em relação aos filmes decorrentes de adaptação de obras literárias, que contaram com apoio e estímulo do governo anterior, concluímos que foi encontrada uma situação inversa na gestão Farias, marcada por uma total ausência de tal estímulo, apesar de no período terem sido realizados 12 filmes deste gênero, financiados pela empresa, através das suas formas tradicionais de financiamentos à época existentes, a partir de critérios estabelecidos pela Embrafilme.

As tentativas de estímulo empreendidas através da Carteira de Coprodução de Filmes Históricos e do Programa especial de pesquisas de temas para filmes históricos apresentaram resultados tímidos. Contraditoriamente, neste período, são produzidos apenas seis filmes históricos. Já no que se refere aos filmes decorrentes de adaptação de obras literária podemos afirmar que havia, de fato, uma ausência total de estímulo a tais produções.

É possível concluir a inexistência de uma política governamental voltada ao cinema brasileiro neste período, ainda que pese o grande número de filmes nacionais lançados no mercado exibidor, pois as ações implementadas não possuíam características de uma política, que deve pensar todas as etapas de um processo, impondo objetivos, metas e controles, que no caso do cinema abranger o ciclo completo da cadeia produtiva (produção, distribuição, exibição).

É interessante notar como a questão do cinema nacional foi tratada por nossos diferentes governos. A relação cinema - Estado sofreu avanços e retrocessos, mas até hoje não superou, o maior de todos os desafios: o de prover a área cinematográfica de uma política de governo, que indicasse um rumo a toda cadeia produtiva.

Não importa a década, mas o percurso estudado referente ao cinema nacional, mostra que apesar do reconhecimento da importância do cinema na divulgação de ações e também de uma ideologia, as iniciativas pensadas para o fomento da atividade, eram pontuais e de certa forma, atendiam somente aos interesses políticos e conjunturais desses governos. 


\section{REFERÊNCIAS}

ALBĖRA, François. Los formalistas rusos y el cine: Lá Poética del Filme. Barcelona: Ediciones Paidós Ibérica S.A., 1998.

ALMEIDA, Claudio Aguiar. O cinema como "agitador de almas". Argila, uma cena do Estado Novo. São Paulo: Annablume/Fapesp, 1999.

ALMEIDA, Joaquim Canuto Mendes de. Cinema contra cinema: Bases gerais para um esboço de organização do cinema educativo no Brasil. São Paulo: Cia. Editora Nacional, 1931.

ALONSO, Gustavo. Simonal, ditadura e memória: Do cara que todo mundo queria ser a bode expiatório. In: ROLLEMBERG, Denise; QUADRAT, Samantha (Orgs.). A construção social dos regimes autoritários: Brasil e América Latina. Rio de Janeiro: Civilização Brasileira, 2010. v. II, p.175-218.

AMANCIO, Tunico. Artes e manhas da Embrafilme: Cinema estatal brasileiro em sua época de ouro (1977 - 1981). Niterói: EdUFF, 2000.

- Produção cinematográfica na vertente estatal (Embrafilme - Gestão Roberto Farias). 1989. Dissertação (Mestrado) - Escola de Comunicações e Artes, Universidade de São Paulo. São Paulo, 1989.

ARAÚJO, Vicente de Paula. A bela época do cinema brasileiro. São Paulo: Perspectiva, 1976.

. Salões, circos e cinemas de São Paulo. São Paulo: Perspectiva, 1981.

BAKHTIN, Mikhail Mikhailovitch. Estética da criação verbal. 6. ed. São Paulo: WMF/ Martins Fontes, 2011.

BARROS, José D'Assunção. Cinema e história: Entre expressões e representações. In: NOVOA, Jorge; BARROS, José D'Assunção (Orgs.). Cinema-história: Teoria e representações sociais no cinema. 2. ed. Rio de Janeiro: Apicuri, 2008. p.43-83.

BASTOS, Elide Rugai; RIDENTI, Marcelo; ROLLAND, Denis (Orgs.). Intelectuais: Sociedade e política, Brasil-França. São Paulo: Cortez, 2003.

BERNARDET, Jean-Claude. Cinema Brasileiro: Propostas para uma história. 2. ed. São Paulo: Schwarcz, 2009. . Historiografia clássica do cinema brasileiro: Metodologia e pedagogia. São Paulo: Annablume, 1995.

. Piranha no mar de rosas. São Paulo: Nobel, 1982. 
; RAMOS, Alcides Freire. Cinema e História do Brasil. São Paulo: Contexto, 1988. (Coleção Repensando a História)

BOBBIO, Norberto. O conceito de sociedade civil. Rio de Janeiro: Edições Graal, 1994. (Biblioteca de Ciências Sociais. Série: Política, 23)

BOJUNGA, Claudio. O artista do impossível. Rio de Janeiro: Objetiva, 2001.

Conclusões do encontro de secretários de cultura: Subsídio para um programa de integração cultural. Rio de Janeiro: Departamento de Assuntos Culturais/MEC, 1976.

1981.

. Fundamentos da doutrina. Rio de Janeiro: Escola Superior de Guerra/ESG,

. Ministério da Cultura. Legislação cinematográfica brasileira em vigor. MinC/Concine, 1989. $\overline{\mathrm{MEC}, 19} 75$.

Ministério da Educação e Cultura. Política nacional de cultura. Brasília:

. Ministério da Educação. Atividades culturais: Realizações da área cultural do MEC no período 1974/78. Rio de Janeiro: MEC, 1979.

CALDAS, Ricardo Wahrendorff; MONTORO, Tânia (Coord.). A evolução do cinema brasileiro no século XX. Brasília: Casa das Musas, 2006.

CAPELATO, Maria Helena et al. História e cinema. São Paulo: Alameda, 2007.

CARONE, Edgard. A primeira República. São Paulo: Difel, 1969.

Difel, 1985.

A República liberal I: Instituições e classes sociais (1945-1964). São Paulo:

. A República liberal II: Evolução política (1945-1964). São Paulo: Difel, 1985a.

A República velha I: Instituições e classes sociais (1889-1930). Rio de Janeiro/São Paulo: Difel, 1978.

. O Estado Novo (1937-1945). Rio de Janeiro: Difel, 1977, p.166-169.

CARVALHO, Alessandra. As atividades político-partidárias e a produção de consentimento durante o regime militar brasileiro. In: ROLLEMBERG, Denise; QUADRAT, Samantha (Orgs.). A construção social dos regimes autoritários: Brasil e América Latina. Rio de Janeiro: Civilização Brasileira, 2010. v.II, p.219-250.

CATANI, Afrânio Mendes. A aventura industrial e o cinema paulista. In: RAMOS, Fernão (Org.). História do cinema brasileiro. 2. ed. São Paulo: Art Editora, 1990. p.189-297. 
CHAUÍ, Marilena. Conformismo e resistência: Aspectos da cultura popular no Brasil. São Paulo: Brasiliense, 1996.

COELHO NETO, José Teixeira. Cultura e sociedade no Brasil: Ensaios sobre ideias e formas. Rio de Janeiro: DP\&A, 2000.

COHN, Gabriel. A concepção oficial da política cultural nos anos 70. In: MICELI, Sérgio (Org.). Estado e cultura no Brasil. São Paulo: Difel, 1984. p.85-96.

COUTO, Ronaldo Costa. História indireta da ditadura e da abertura. Brasil: 19641985. Rio de Janeiro: Record, 1999.

D'ARAUJO, Maria Celina; CASTRO, Celso (Orgs.). Ernesto Geisel. 5. ed. Rio de Janeiro: Fundação Getúlio Vargas, 1997.

FALCÃO, Joaquim Arruda. Política cultural e democracia: A preservação do patrimônio histórico e artístico nacional. In: MICELI, Sérgio (Org.). Estado e cultura no Brasil. São Paulo: Difel, 1984. p.21-40.

FERRO, Marc. Cinema e história. Rio de Janeiro: Paz e Terra, 1992.

FICO, Carlos. 1968: O ano que terminou mal. In: ARAUJO, Maria Paula (Orgs.). 1968, 40 anos depois: História e memória. Rio de Janeiro: 7Letras, 2009. p.223-242.

; ARAUJO, Maria Paula (Orgs.). 1968, 40 anos depois: História e memória. Rio de Janeiro: 7Letras, 2009.

; FERREIRA, Marieta de Moraes; ARAUJO, Maria Paula (Orgs.) Ditadura e democracia na América Latina: Balanço histórico e perspectivas. Rio de Janeiro: FGV, 2008.

FURHAMMAR, Leif; ISAKSSON, Folke. Cinema e política. Rio de Janeiro: Paz e Terra, 1976. (Coleção Cinema, v.2).

GALVÃO, Maria Rita Eliezer. Burguesia e cinema: O caso Vera Cruz. Rio de Janeiro: Civilização Brasileira, 1981. (Cinebiblioteca Embrafilme).

. Crônica do cinema paulistano. São Paulo: Ática, 1975.

; SOUZA, Carlos Roberto. Cinema brasileiro: 1930-1964. In: FAUSTO, Boris (Org.). História geral da civilização. O Brasil Republicano. São Paulo: Difel, 1984, tomo III, v.IV.

GARCÍA CANCLINI, Nestor: Culturas híbridas. Estratégias para entrar e sair da modernidade. São Paulo: Edusp, 1997.

GASPARI, Elio. A ditadura derrotada. São Paulo: Companhia das Letras, 2003. (Coleção As Ilusões Armadas, 3). 
A ditadura encurralada. São Paulo: Companhia das Letras, 2004. (Coleção As llusões Armadas, 4).

A ditadura envergonhada. São Paulo: Companhia das Letras, 2002. (Coleção As llusões Armadas, 1).

. A ditadura escancarada. São Paulo: Companhia das Letras, 2002. (Coleção As llusões Armadas, 2).

GATTI, André Piero. Cinema brasileiro ritmo de indústria (1969-1990). São Paulo: Secretaria Municipal de Cultura, 1999b.

. Embrafilme e o cinema brasileiro [recurso eletrônico]. São Paulo: Centro Cultural São Paulo, 2007. (Cadernos de pesquisa, 6).

O consumo e o comércio cinematográficos no Brasil vistos através da distribuição de filmes nacionais: Empresas distribuidoras e filmes de longa-metragem (1966-1990). 1999. Dissertação (Mestrado em Comunicação) - Escola de Comunicações e Artes, Universidade de São Paulo. São Paulo, 1999a.

GERTZ, René. Estado Novo: Um inventário historiográfico. In: SILVA, José Luiz Werneck da (Org.). O feixe: O autoritarismo como questão teórica historiográfica. Rio de Janeiro: Jorge Zahar, 1991.

GOMES, Angela de Castro. Estado Novo: Ambiguidades e heranças do autoritarismo no Brasil. In: ROLLEMBERG, Denise; QUADRAT, Samantha (Orgs.). A construção social dos regimes autoritários: Brasil e América Latina. Rio de Janeiro: Civilização Brasileira, 2010. v.II. p.34-70.

Propaganda política, construção do tempo e do mito Vargas: O calendário de 1940. In: BASTOS, Elide Rugai; RIDENTI, Marcelo; ROLLAND, Denis (Orgs.). Intelectuais: Sociedade e política, Brasil-França. São Paulo: Cortez, 2003. p.112146.

GOMES, Paulo Emílio Salles. Cinema: Trajetória no subdesenvolvimento. São Paulo: Paz e Terra, 1996.

HALL, Stuart. A identidade cultural na pós-modernidade. Rio de Janeiro: DP\&A, 2004.

HOBSBAWN, Eric; RANGER, Terence. A invenção das tradições. São Paulo: Paz e Terra, 2008.

HINGST, Bruno. Roberto Farias: Uma perspectiva mercadológica positiva para o cinema brasileiro. 2001. Dissertação (Mestrado) - Faculdade de Comunicação Social, Faculdade Cásper Líbero. São Paulo, 2001.

JOHNSON, Randal. The film industry in Brazil: Culture and the state. Pitisburgo: University of Pittsburgh Press, 1987. 
LEITE, Sidney Pereira. Cinema brasileiro: Das origens à retomada. São Paulo: Fundação Perseu Abramo, 2005.

MACHADO, Mario Brockmann. Políticas públicas na área cultural. In: MICELI, Sérgio (Org.). Estado e cultura no Brasil. São Paulo: Difel, 1984. p.5-20.

MICELI, Sérgio (Org.). Estado e cultura no Brasil. São Paulo: Difel, 1984.

. O processo de "construção institucional" na área cultural federal (anos 70).

In: ___ Estado e cultura no Brasil. São Paulo: Difel, 1984. p.53-84.

. Teoria e prática da política cultural oficial no Brasil. In: . Estado e cultura no Brasil. São Paulo: Difel, 1984. p.97-112.

MORETTIN, Eduardo. O cinema como fonte histórica na obra de Marc Ferro. In: CAPELATO, Maria Helena et al. História e cinema. São Paulo: Alameda, 2007. p.39-64.

MOTA, Carlos Guilherme. Ideologia da cultura brasileira: Pontos de partida para uma revisão histórica. São Paulo: Ática, 1977.

NAGIB, Lúcia. O cinema da retomada: Depoimentos de 90 cineastas dos anos 90. São Paulo: 34, 2002.

NAPOLITANO, Marcos. Cultura. In: Pinsky, Jaime (Org.). O Brasil no contexto: 19872007. 2. ed. São Paulo: Contexto, 2007. p.139-149.

. Cultura brasileira: Utopia e massificação (1950-1980). 3. ed. São Paulo: Contexto, 2008. (Repensando a História).

. Cultura e poder no Brasil contemporâneo. Curitiba: Juruá, 2006.

. O regime militar brasileiro: 1964-1985. São Paulo: Atual, 1998. (Discutindo a História do Brasil).

. "Vencer satã só com orações": Políticas culturais e cultura de oposição no Brasil dos anos 1970. In: ROLLEMBERG, Denise; QUADRAT, Samantha (Orgs.). A construção social dos regimes autoritários: Brasil e América Latina. Rio de Janeiro: Civilização Brasileira, 2010. v. II, p.145-174.

NOBRE, F. Silva. Pequena história do cinema brasileiro. Rio de Janeiro: Associação Atlética Banco do Brasil, 1955.

NÓVOA, Jorge. Apologia da relação cinema-história. In: ; BARROS, José D’Assunção (Orgs.). Cinema-história: Teoria e representações sociais no cinema. 2. ed. Rio de Janeiro: Apicuri, 2008. p.13-40.

; BARROS, José D’Assunção (Orgs.). Cinema-história: Teoria e representações sociais no cinema. 2. ed. Rio de Janeiro: Apicuri, 2008. 
OLIVEIRA, Eliézer Rizzo de. De Geisel a Collor: Forças armadas, transição e democracia. Campinas, SP: Papirus, 1994. (Coleção Estado e Política).

OLIVEN, Ruben George. A relação Estado e Cultura no Brasil: Cortes ou continuidade? In: MICELI, Sérgio (Org.). Estado e cultura no Brasil. São Paulo: Difel, 1984. p.41-52.

ORTIZ, Renato. A moderna tradição brasileira. São Paulo: Brasiliense, 2001.

PARREIRA, Roberto. Estado e cultura: fomento "versus" paternalismo. In: MICELI, Sérgio (Org.). Estado e cultura no Brasil. São Paulo: Difel, 1984. p.223-240.

PEREIRA, Geraldo Santos. Plano geral do cinema brasileiro. Rio de Janeiro: Borsoi, 1973.

PEREIRA Junior, Araken Campos. Cinema brasileiro (1908-1978): Longa Metragem. Santos: Casa do Cinema, 1979. v.ll.

PINSKY, Jaime (Org.). O Brasil no contexto: 1987-2007. 2. ed. São Paulo: Contexto, 2007.

PRESOT, Aline. Celebrando a "Revolução": as marchas da família com Deus pela liberdade e o golpe de 1964. In: ROLLEMBERG, Denise; QUADRAT, Samantha (Orgs.). A construção social dos regimes autoritários: Brasil e América Latina. Rio de Janeiro: Civilização Brasileira, 2010. v.II, p.71-96.

RAMOS, Fernão (Org.). História do cinema brasileiro. 2. ed. São Paulo: Art Editora, 1990.

RAMOS, Fernão Pessoa; MIRANDA, Luiz Felipe A. (Orgs.). Enciclopédia do Cinema Brasileiro. São Paulo: SENAC São Paulo, 2000.

RAMOS, José Mario Ortiz. Cinema, estado e lutas culturais: Anos 50, 60, 70. Rio de Janeiro: Paz e Terra, 1983. (Coleção Cinema, 16)

REZENDE, Maria José de. A ditadura militar no Brasil: Repressão e pretensão de legitimidade 1964 - 1984. Londrina: UEL, 2001.

RIDENTI, Marcelo. A época de 1968: cultura e política. In: FICO, Carlos; ARAUJO, Maria Paula (Orgs.). 1968: 40 anos depois - história e memória. Rio de Janeiro: 7Letras, 2009. p.81-104. UNESP, 2010.

Brasilidade revolucionária: Um século de cultura e política. São Paulo: . Cultura e política brasileira: Enterrar os anos 60? In: BASTOS, Elide Rugai; RIDENTI, Marcelo; ROLLAND, Denis (Orgs.). Intelectuais: Sociedade e política, Brasil-França. São Paulo: Cortez, 2003. p.197-212.

. Em busca do povo brasileiro. Rio de Janeiro: Record, 2000. 
ROLLAND, Denis. O estatuto da cultura no Brasil do Estado Novo: Entre o controle das culturas nacionais e a instrumentalização das culturas estrangeiras. In: BASTOS, Elide Rugai; RIDENTI, Marcelo; ROLLAND, Denis (Orgs.). Intelectuais: Sociedade e política, Brasil-França. São Paulo: Cortez, 2003. p.85-111.

ROLLEMBERG, Denise. As trincheiras da memória: A Associação Brasileira de Imprensa e a ditadura (1964-1974). In: ; QUADRAT, Samantha (Orgs.). A construção social dos regimes autoritários: Brasil e América Latina. Rio de Janeiro: Civilização Brasileira, 2010. v.II, p.97-144.

; QUADRAT, Samantha (Orgs.). A construção social dos regimes autoritários: Brasil e América Latina. Rio de Janeiro: Civilização Brasileira, 2010. v. II.

ROSENSTONE, Robert A. A história nos filmes, os filmes na história. São Paulo: Paz e Terra, 2010.

. El pasado en imagines: El desafio del cine a nuestra Idea de la historia. Barcelona: Ariel,1997.

Visions of the past: The challenger of film to our idea of history. Cambridge: Harvard University Press, 1995.

ROUQUIÉ, Alain (Coord.). Os processos políticos nos partidos militares do Brasil: Estratégia de pesquisa e dinâmica institucional. In: ROUQUIÉ, Alain (Coord.). Os partidos militares no Brasil. São Paulo: Record, s/d, p. 9-26. Disponível em: $<$ http://books.google.com.br/books?id=iY2EgIWpAWoC\&pg=PA12\&lpg=PA12\&dq=Al ain+Rouquié+partido+militar\&source=bl\&ots=nsKhvlZTAX\&sig=LoXXAi4EKm1sCKZz zl-esG8OeGo\&hl=en\&sa=X\&ei=OvRkUKD>. Acesso em: 16 out. 2012.

SÁ NETO, A.A.F. O pensamento industrial cinematográfico brasileiro. 2004. Tese (Doutorado em Multimeios) - Instituto de Artes, Universidade Estadual de Campinas. Campinas, 2004. Disponível em: $<$ http://www.bibliotecadigital.unicamp.br/document/?code=vtls000349566\&fd=y $>$. Acesso em: 10/dez/2012.

SADOUL, Georges. História do cinema mundial: Das origens aos nossos dias. Lisboa: Livros Horizontes, 1983. v.ll.

SALIBA, Maria Eneida Fachini. Cinema contra cinema: O cinema educativo de Canuto Mendes (1922-1931). São Paulo: Annablume/ Fapesp, 2003.

SANTOS, Milton. O espaço do cidadão. 7. ed. São Paulo: Edusp, 2007. (Coleção Milton Santos, 8)

SÃO PAULO (ESTADO). Secretaria da Cultura. Filmografia do cinema brasileiro, 1900-1935. Comissão de Cinema. 1979.

SÃO PAULO (PREFEITURA). Secretaria de Educação e Cultura. Situação econômica e financeira do cinema nacional. Comissão Nacional de Cinema. 1955. 
SCHVARZMAN, Sheila. Humberto Mauro e as imagens do Brasil. São Paulo: UNESP, 2004.

SCHWARTZMAN, Simon; BOMENY, Helena Maria Bousquet; COSTA, Vanda Maria Ribeiro. Tempos de Capanema. São Paulo: Paz e Terra/ Fundação Getúlio Vargas, 2000.

SERRANO, Jonathas; VENÂNCIO Filho, Francisco. Cinema e educação. São Paulo: Melhoramentos [1930].

SEVCENKO, Nicolau. História da vida privada no Brasil: República - da Belle Époque à era do rádio. São Paulo: Cia. das Letras. 1999. v.3.

SILVA, Golbery do Couto. Conjuntura política nacional: O poder executivo \& geopolítica do Brasil. 3. ed. Rio de Janeiro: J. Olympio, 1981a.

. Planejamento estratégico. 2. ed. Brasília: Universidade de Brasília, 1981b.

SILVA, José Luiz Werneck da (Org.). O feixe: O autoritarismo como questão teórica historiográfica. Rio de Janeiro: Jorge Zahar Editor, 1991.

SILVA, Vanderli Maria da. A construção da política cultural no regime militar: Concepção, diretrizes e programas (1974-1978). 2001. Dissertação (Mestrado em Sociologia). Faculdade de Filosofia, Letras e Ciências Humanas da Universidade de São Paulo. São Paulo, 2001.

SILVA NETO, Antônio Leão da. Dicionário de filmes brasileiros. São Bernardo do Campo, S.P.: A.L. Silva Neto, 2002.

Dicionário de filmes brasileiros. Longa metragem. 2. ed. São Bernardo do Campo, S.P.: A.L. Silva Neto, 2009.

SIMIS, Anita. Estado e cinema no Brasil. 1. ed. São Paulo: Annablume, 1996.

SIMÕES, Inimá. Roteiro da intolerância: A censura cinematográfica no Brasil. São Paulo: SENAC, 1999.

SKIDMORE, Thomas E. Brasil: De Getúlio a Castelo, 1930-1964. 12. ed. Rio de Janeiro: Paz e Terra, 2000.

. Uma história do Brasil. 4. ed. São Paulo: Paz e Terra, 1998.

SODRÉ, Muniz. O mercado de bens culturais. In: MICELI, Sérgio (Org.). Estado e cultura no Brasil. São Paulo: Difel, 1984. p.135-144.

SOUZA, Carlos Roberto de. Catálogo de filmes produzidos pelo INCE. Rio de Janeiro: Fundação do Cinema Nacional Brasileiro, 1990.

SOUZA, José Inácio de Melo. A ação e o imaginário de uma ditadura: Controle, coerção e propaganda política nos meios de comunicação durante o Estado Novo. 
Campinas: Unicamp, 1987.

STAN, Robert. Bakhtin: Da teoria literária à cultura de massa. São Paulo: Ática, 1992. (Série Temas, v.20)

Multiculturalismo tropical: Uma história comparativa da raça na cultura e no cinema brasileiro. São Paulo: Edusp, 2008.

TOLEDO, Caio Navarro de. ISEB: Fábrica de ideologias. 2. ed. Campinas: Unicamp, 1997.

VARGAS, Getúlio. O cinema nacional elemento de aproximação dos habitantes do país. Discurso pronunciado na manifestação promovida pelos cinematografistas, em 25 de junho de 1934. Brasil. Biblioteca da Presidência da república. Casa Civil. Disponível em: <http://www.biblioteca.presidencia.gov.br/ex-presidentes/getuliovargas/discursos-1/1934/04.pdf/download>. Acesso em: 04 abr. 2013.

VIANY, Alex. Introdução ao cinema brasileiro. Rio de Janeiro: Instituto Nacional do Livro, 1959.

VIEIRA, Marcelo Dídimo Souza. O cangaço no cinema brasileiro. 2007. Tese (Doutorado em Artes) - Instituto de Artes, Universidade de Campinas. Campinas, S.P., 2007.

WILLIAMS, Raymond. Cultura. Rio de Janeiro: Paz e Terra, 2000.

XAVIER, Ismail. Sétima arte: Um culto ao moderno. São Paulo: Perspectiva, 1978.

. O discurso cinematográfico: A opacidade e a transparência. 2. ed. Rio de Janeiro: Paz e Terra, 1984. (Coleção Cinema, 4)

\section{Revistas eletrônicas}

FICO, Carlos. O golpe de 1964 e o papel do governo dos EUA. In: et al. Ditadura e democracia na América Latina: Balanço histórico e perspectivas. Rio de Janeiro: Editora FGV, 2008. p.53-76. Disponível em: <http://books.google.com.br/books?id=PIUa3KoWpd0C\&pg=PP4\&lpg=PP4\&dq=semi n\%C3\%A1 rio+internacional++ditadura+e+democracia+na+am\%C3\%A9rica+latina:+ balan\%C3\%A7o+hist\%C3\%B3rico+e+perspectivas\&source=bl\&ots=a LFfM2Wrp\&si $\mathrm{g}=$ YPqSFA9CHAbNo8ITukJTqp6q2fk\&hl=en\&sa=X\&ei=pS\#v=onepage\&q=semin \%C 3\%A1rio\%20internacional $\% 20 \% 20$ ditadura $\% 20 \mathrm{e} \% 20$ democracia $\% 20$ na $\% 20$ am $\% \mathrm{C3}$ \%A9rica\%20latina\%3A\%20balan\%C3\%A70\%20hist\%C3\%B3rico\%20e\%20perspecti vas\&f=false $>$. Acesso em: 12 mai. 2012.

. "Prezada censura": Cartas ao regime militar. In: Topoi. Revista de História. Rio de Janeiro, v.3, julho-dezembro de 2002, p.251-286. Disponível em: $<$ http://www.revistatopoi.org/numeros anteriores/topoi05/topoi5a11.pdf>. Acesso em: 12 mai. 2012. 
Versões e controvérsias sobre 1964 e a ditadura militar. In: Revista

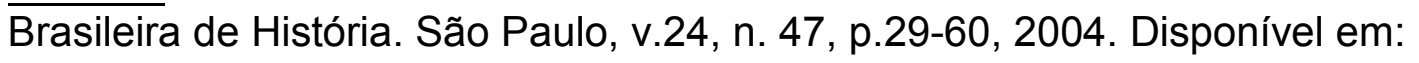
<http://www.scielo.br/pdf/rbh/v24n47/a03v2447.pdf>. Acesso em: 12 mai. 2012.

KORNIS, Mônica Almeida. História e Cinema: Um debate metodológico. In: Revista Estudos Históricos. Rio de Janeiro, v. 5, n. 10, 1992, p. 237-250. Disponível em: <http://virtualbib.fgv.br/ojs/index.php/reh/article/view/1940/1079>. Acesso em: 01 mai. 2010.

LOWENTHAL, David. Como conhecemos o passado. In: Revista Projeto História. v.17, 1998, p.63-201. Disponível em: $<$ http://revistas.pucsp.br/index.php/revph/article/view/11110/8154>. Acesso em: 15 dez. 2012.

NAPOLITANO, Marcos. A arte engajada e seus públicos (1955/1968). In: Estudos Históricos. Rio de Janeiro, n. 28, 2001, p.103-124. Disponível em: <http://bibliotecadigital.fgv.br/ojs/index.php/reh/article/viewFile/2141/1280> Acesso em: 25 out. 2012.

A relação entre arte e política: Uma introdução teórico-metodológica. In: Temáticas, n. 37-38, Campinas, São Paulo, 2010a. Disponível em: <http://pt.scribd.com/doc/75775928/Arte-Politica-Napolitano-Tematicas>. Acesso em: 15 jul. 2012.

NOVA, Cristiane. O cinema e o conhecimento da História. In: Revista Olho da História. Salvador, n.3, 1996. Disponível em:

<http://www.oolhodahistoria.ufba.br/o3cris.html>. Acesso em 15 jun. 2012.

NÓVOA, Jorge. Apologia da relação cinema-história. In: Revista Olho da História. Salvador, n.1, 1995. Disponível em: <http://www.oolhodahistoria.ufba.br/01apolog.html>. Acesso em: 01 mai. 2010.

PINTO, Luciana. O historiador e sua relação com o cinema. In: Revista Olho da História. Salvador, 2004, n.6, p.1-8. Disponível em: <http://www.oolhodahistoria.ufba.br/artigos/historiadoreocinema.pdf_>. Acesso em: 01 mai. 2010.

RIDENTI, Marcelo. Artistas e intelectuais no Brasil pós-1960. In: Tempo Social. São Paulo, 17/01, junho de 2005, p. 97. Disponível em: <http://www.scielo.br/pdf/ts/v17n1/v17n1a03.pdf>. Acesso em: 20 set. 2012. . Intelectuais e artistas brasileiros nos anos 1960/70: "Entre a pena e o fuzil". In: Revista ArtCultura, Uberlândia, n. 14, jan.-jun. 2007, v.9, p.185-195. <Disponível em: <http://www.seer.ufu.br/index.php/artcultura/article/view/1457/1304 > Acesso em: 20 out. 2012.

ROSSINI. Miriam de Souza. Rebeldes nas Telas: Um Olhar sobre os Filmes de Reconstituição Histórica. In: Revista de História e Estudos Culturais, São Leopoldo, Rio Grande do Sul, jan.-mar. 2006, v. 3. Ano III. n. 1. Disponível em: 
<http://www.revistafenix.pro.br/PDF6/14\%20-\%20DOSSIE\%20-\%20ARTIGO\%20\%20MROSSINI.pdf>. Acesso em: 01 mai. 2010.

SÁ NETO, A.A.F. A questão da indústria cinematográfica brasileira na primeira metade do século. 2008.2 Disponível em: $<$ http://www.mnemocine.art.br/index.php? view=article\&catid=35\%3Ahistcinema\&id=6 4\%3Aa-questao-da-industria-cinematografica-brasileira-na-primeira-metade-doseculo\&format=pdf\&option=com content\&ltemid=67> . Acesso em: 13 abr. 2011.

SIMIS. Anita. Contribuição da cota de tela no cinema brasileiro. In: Revista O Público e o privado. Ceará, jul/dez 2009, n. 14, p.137-146. Disponível em: $<$ http://www.seer.uece.br/?=opublicoeoprivado\&page=article\&op=view\&path\% 5B\%5D=95\&path\%5B\%5D $=160>$. Acesso em: 19 abr. 2011.

\section{Sites}

BRASIL. Agência Nacional do Cinema - ANCINE. Disponível em: www.ancine.gov.br.

ADORO CINEMA. <http://www.adorocinema.com/filmes/letra/>

ARCHIVO STORICO EMIGRAZIONE ITALIANA. Italianos no cinema brasileiro.

<http://www.asei.eu/index.php?option=com content\&task=view\&id=99\&ltemid=1>

CINECLICK. <http://www.cineclick.com.br/filmes>

CINEMA 10. <http://cinema10.com.br/>

CINEMATECA BRASILEIRA < http://www.cinemateca.org.br $>$

CINEMA TOTAL. <http://www.cinematotal.com/>

CINEMINHA. < http://cineminha.com.br/filmes/>

HISTÓRIA DO CINEMA BRASILEIRO.

< $\underline{\text { http://www.historiadocinemabrasileiro.com.br/category/filmografia-brasileira/> }}$

INTERFILMES. Disponível em <http://www.interfilmes.com/nacionais.html>

MEU CINEMA BRASILEIRO.

<http://www.meucinemabrasileiro.com/filmes/filme a.asp> 


\section{ANEXO A \\ FILMES HISTÓRICOS (1974-1979) \\ Fonte: (AMANCIO, 2000, p.130-179)}

\section{Ajuricaba, o Rebelde da Amazônia (1977)}

\section{Ficha Técnica}

Diretor: Oswaldo Caldeira

Roteiristas: Oswaldo Caldeira, Almir Muniz

Lançamento (Brasil): 1977

Fotografia: Edison Santos

Edição: Carlos Brajsblat

Música: Airton Barbosa

Produção: Oswaldo Caldeira, Embrafilme, Fundação Cultural do Estado do Amazonas

\section{Elenco:}

Sura Berditchevsky

Emmanuel Cavalcanti

Euthímio Gomes de Carvalho

Fregolente

Rinaldo Gines

Amir Haddad

José Kleber

Aurélio Michilis

Carlos Eduardo Novaes

Nildo Parente

Maria Sílvia

Vânia Velloso

Paulo Villaça

Carlos Wilson

\section{Sinopse}

O filme baseado em episódio da História do Brasil, se passa no século XVIII e narra a resistência de Ajuricaba, índio chefe de uma tribo de Manaus, à presença do colonizador português na região. que se tornou guerreiro e liderou uma revolta contra os colonizadores portugueses na Amazônia. Foi filmado na floresta amazônica e região.

\section{Fonte:}

http://epipoca.uol.com.br/filmes_detalhes.php?idf=6574

\section{Anchieta, José do Brasil (1978)}

\section{Ficha Técnica}

Gênero: Drama/Histórico

Duração: 150 min.

Lançamento (Brasil): 1978

Distribuição: Embrafilme

Direção: Paulo César Saraceni

Roteiro: Paulo César Saraceni

Argumento: Paulo Cezar Saraceni, Marcos Konder Reis e Humberto Mauro

Produção: Embrafilme e Santana Filmes

Música: Sérgio Guilherme Saraceni

Fotografia: Marco Bottino

Desenho de produção: Ferdy Carneiro 
Figurino: Metka Koshak, Vera Barreto Leite e Hélio Braga

Edição: Ricardo Miranda

\section{Elenco}

Ney Latorroca (José de Anchieta)

Luiz Linhares (Manoel da Nóbrega)

Maurício do Valle (João Ramalho)

Joel Barcellos (Tibirica)

Hugo Carvana (Diogo Álvares)

Paulo César Pereio (Jeandes Bolés)

Maria Gladys

Vera Barreto Leite

Ana Maria Magalhães

Roberto Bonfim

Ana Maria Miranda

Dedé Veloso

Manfredo Colassanti

Carlos Kroeber

Wilson Grey

António Carnera

Ambrósio Fregolente

Rui Pollanah

Rejane Medeiros

\section{Sinopse}

O filme narra a vida do padre José de Anchieta, que chegou ao Brasil em 1553, e que lutou pela convivência pacífica entre colonos vindos da Europa para o Brasil e os índios que aqui viviam.

Fonte:

http://www.meucinemabrasileiro.com/filmes/anchieta-jose-do-brasil/anchieta-jose-do-brasil.asp

\section{Batalha dos Guararapes, O Príncipe de Nassau (1978)}

\section{Ficha Técnica}

Gênero: Aventura

Duração: 156 min.

Lançamento (Brasil): 1978

Distribuição: Embrafilme e Lívio Bruni

Direção: Paulo Thiago

Roteiro: Paulo Thiago, Armando Costa, Miguel Borges e Gustavo Dahl

Produção: Carlos Henrique Braga, Sargitário Filmes

Música: Guerra Peixe

Fotografia: Mário Carneiro Renato Neumann e José Antônio Ventura

Efeitos especiais: Nino Batisteli

Figurino: Diva Mendonça

Edição: Nello Melli

Instrutor de Esgrima: Jurandir Viana

\section{Elenco}

José Wilker (João Fernandes)

Cristina Aché

Joel Barcellos

Roberto Bonfim

Renée de Vielmond

Jardel Filho

Germano Haiut

Jacqueline Laurence

Ednaldo Lucena

Marcos Macena 
José Pimentel

Carlos Reis

Fausto Rocha Jofre Soares

Tamara Taxman

Marcus Vinícius

Sinopse

O filme, considerado a primeira superprodução brasileira, recria um dos principais episódios da batalha entre holandeses e luso-brasileiros nas proximidades de Recife/Pernambuco e retrata as forças econômicas e políticas que moveram aquele período.

\section{Fonte:}

http://www.meucinemabrasileiro.com/filmes/batalha-dos-guararapes/batalha-dosguararapes.asp

http://cinebrasilis.blogspot.com/2008/04/batalha-dos-guararapes-o-prncipe-de.html

\section{Coronel Delmiro Gouveia (1978)}

\section{Ficha Técnica}

Ano: 1978

Cidade: RJ

País: Brasil

Gênero: Ficção

Direção: Geraldo Sarno

Roteiro: Geraldo Sarno, Orlando Senna

Empresa(s) Co-produtora(s): Saruê Filmes

Co-produção: Embrafilme

Produção Executiva: Marco Altberg

Direção Fotografia: Lauro Escorel Filho

Assistente de Câmera: José Tadeu Ribeiro

Montagem/Edição: Amauri Alves

Direção de Arte: Anísio Medeiros

Sound Designer: Walter Goulart

Descrições das Trilhas: Música original: J. Lins

\section{Elenco:}

Rubens de Falco

Nildo Parente

Jofre Soares

Sura Berditchvski

José Dumont

Isabel Ribeiro

Magalhães Graça

Conceição Senna

Álvaro Freire

Maria Alves

Denis Bourke

Harildo Deda

Maria Adélia

Henrique

João Gama

Guerra.

Participação:

Jota

S. João

D. Filinha

Tonico

Sinopse 
O filme conta a vida de Delmiro Gouveia, comerciante e exportador recifense que falido, sofre perseguições pela polícia do Governador, quando então foge para o sertão, monta uma fábrica de linhas de costura, que passa a ser comprada pelos ingleses da Machine Cottons. Delmiro nega-se a vendê-la, é assassinado em outubro de 1917 e a fábrica adquirida pelos ingleses é destruída e lançada nas águas da Cachoeira de Paulo Afonso.

Fonte:

http://www.programadorabrasil.org.br/filme/346/

\section{Tiradentes Mártir da Independência (1977)}

\section{Ficha Técnica}

Companhia(s) produtora(s): Art Films; E. C. Distribuição Importação e Produção

Cinematográfica Ltda.

Produção: Cassiano Esteves

Produção executiva: Duarte Gil Gouveia

Ano: 1977

Assistência de produção: Agenor Vernin

Distribuição: Companhia(s) distribuidora(s): Marte Art

Argumento: Geraldo Vietri; Sérgio Galvão

Roteiro: Geraldo Vietri

Direção: Geraldo Vietri

Assistência de direção: Agenor Vernin

Direção de fotografia: Antonio B.Thomé

Câmera: Antonio B. Thomé

Assistência de câmera: Nicanor de Oliveira; Edmilson Rocha; José Dias,

Fotografia de cena: Waldir Silva

Técnico de som: Pedro Luiz Nobile

Montagem: Geraldo Vietri

Montagem de som: Lúcio Braun

Direção de arte: Rodolfo Machado

Figurinos: Vida Sanches

Cenografia: Agenor Vernin; Roberto Rocco

Maquiagem: Lázaro de Oliveira Neto

Penteados: Arnaldo Moscardini

Seleção musical: Geraldo Vietri

Música de: Carlos Gomes

Elenco

Adriano Reys (Joaquim José da Silva Xavier)

Cláudio Correia de Castro (Visc. Barbacena)

Chico Martins (Silvério dos Reis)

Paulo Figueiredo (José Maciel)

lara Lins

Wilson Fragoso

Turíbio Ruiz

Xandó Batista

Eduardo Abbas

Oswaldo Camposana

Amilton Monteiro

Francisca Lopes

Sérgio Antonio

José Luiz Di Santo

José de Nicoló

Géza Kauffman

Abrahão Farc

José Policena

Guberos Netto 
Lino Braga

Maria do Carmo

Álvaro de Albuquerque

Luiz Dias

Osvaldo Mesquita

Rogaciano de Freitas

Cassiano Ricardo

Roberto Rocco

Atores convidados:

Kate Hansen (Viscondessa de Barbacena)

Participação especial:

Benjamin Cattan (Vice-Rei)

Laura Cardoso (Vice-Rainha)

\section{Sinopse}

Filme narra a trajetória de Joaquim José da Silva Xavier, Tiradentes, líder da Inconfidência Mineira, movimento surgido em Vila Rica (Ouro Preto) em 1789. Tiradentes sonhou junto com amigos e intelectuais ver o Brasil independente do domínio português, mas esbarrou na traição de Joaquim Silvério dos Reis.

Fontes:

http://www.meucinemabrasileiro.com/filmes/tiradentes/tiradentes.asp

\section{Xica da Silva (1976)}

\section{Ficha Técnica}

Título original: Xica da Silva

Gênero: Comédia

Duração: 117 min.

Lançamento (Brasil): 1976

Distribuição: Embrafilme e Unifilms

Direção: Carlos Diegues

Roteiro: Carlos Diegues e João Felicio dos Santos

Produção: Jarbas Barbosa, Airton Correa,

Hélio Ferraz, José Oliosi, Embrafilme, Distrifilmes e Terra Filmes

Música: Jorge Ben e Roberto Menescal

Fotografia: José Medeiros

Desenho de produção: Luiz Carlos Ripper

Direção de arte: Luiz Carlos Ripper

Figurino: Luiz Carlos Ripper

Edição: Mair Tavares

\section{Elenco}

Zezé Motta (Xica da Silva)

Walmor Chagas (Comendador João Fernandes)

Altair Lima (Theodoro)

Elke Maravilha (Hortensia)

Stepan Nercessian (José)

Rodolfo Arena (Sargento-Mor)

José Wilker (Conde de Valadares)

Marcus Vinícius (Teodoro)

João Felicio dos Santos (Paroco)

Dara Kocy (Zefina)

Adalberto Silva (Cabeça)

Julio Mackenzie (Raimundo)

Beto Leão (Mathias)

Luis Motta (Taverneiro)

Paulo Padilha (Ourives)

Baby Conceicao (Figena) 
lara Jati (Tonha)

Alberto Patu

Luis Felipe (Major)

Gloria Cristal

Tony Ferreira

Clementino Kelé

Antônio Pompêo

Sinopse

O filme narra a trajetória de Xica da Silva, escrava que se tornou a primeira dama negra de nossa história, seduzindo o milionário contratador de diamantes João Fernandes de Oliveira.

Fonte:

http://www.meucinemabrasileiro.com/filmes/xica-da-silva/xica-da-silva.asp

http://www.historianet.com.br/conteudo/default.aspx?codigo=301 


\section{ANEXO B \\ ADAPTAÇÃO DE OBRAS LITERÁRIAS \\ (1974-1979) \\ Fonte: (AMANCIO, 2000, p.130-179)}

Coronel e o Lobisomem, $\mathrm{O}$ (1979)

Ficha Técnica

Ano: 1979

Gênero: Aventura

Duração: 110 min.

Tipo: Longa-metragem / Colorido

Distribuidora: Embrafilme

Produtora(s): Alcino Diniz Filmes, Diniz Filmes, Embrafilme

Diretor: Alcino Diniz

Roteirista: José Cândido de Carvalho, Alcino Diniz

Fotógrafo: Antônio Gonçalves

Produtores: Alcino Diniz e Maria Santo Cristo

Compositor(es): Marco Versiani e Helvius Vilela

Montagem: Giuseppe Baldacconi

Decorador(es): Nilton Rabelo e Wagner Seixas

Figurinista: Amélia Bezerra de Menezes

Departamento de Arte: Jurandir de Oliveira

Departamento de Som: Roberto Leite e José Tavares

Elenco:

Maurício do Valle

Maria Cláudia

Cléa Simões

Jofre Soares

Nildo Parente

Selma Egrei

Louise Cardoso

Isabel Ribeiro

Lutero Luiz

Fernando Reski

Alfredo Clemente

Amauri Guarilha

Antonio Ganzarolli

Emmanuel Cavalcanti

Erley José

Germano Filho

Gloria Cristal

José Steimberg

Jotta Barroso

Lídia Costa

Lídia Mattos

Marcus Vinícius

Neila Tavares

Otávio Augusto 


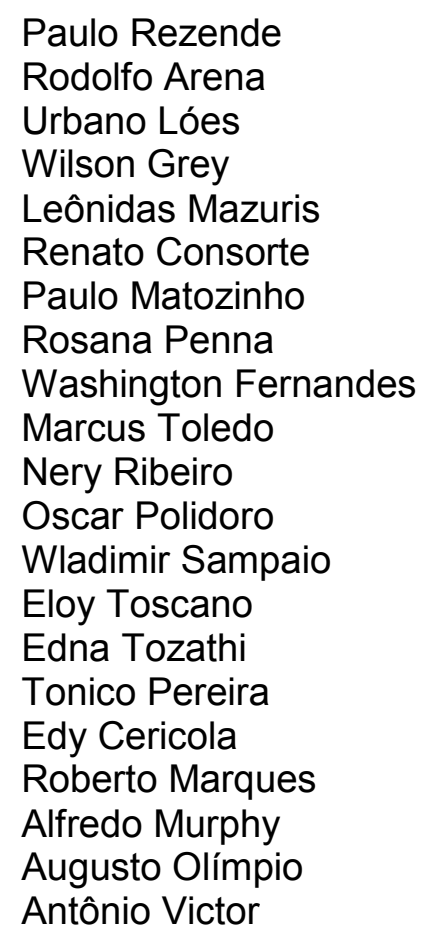

\section{Sinopse}

Filme baseado na obra homônima de José Cândido de Carvalho e conta a história de Ponciano de Azeredo Furtado, um coronel de patente e fazendeiro que luta contra seu irmão de criação, Pernambuco Nogueira, por interesse em manter as terras da Fazenda Sobradinho e conquistar o coração da sua prima Esmeraldina.

Fonte:

http://epipoca.uol.com.br/filmes_ficha.php?idf=7281

\section{Cortiço, O (1978)}

\section{Ficha Técnica}

Ano: 1978

Gênero: Drama

Duração: 110 min.

Tipo: Longa-metragem / Colorido

Distribuidora: Embrafilme

Produtora: Argos Filmes

Diretor: Francisco Ramalho Jr.

Roteirista(s): Aluísio Azevedo e Francisco Ramalho Jr.

Fotógrafo: Zetas Malzoni

Produtor(es): Renata Cabrera, Edgard Castro e Luiz A. Livieri

Compositor música original: John Neschling

Montagem: Silvio Renoldi

Direção de Arte: Régis Monteiro

Figurinista: Régis Monteiro

Som: Edson Gallioti e José Luiz Sasso

Elenco:

Maria Alves

Marco Antônio

Phydias Barbosa

Leonidas Bayer

Armando Bógus

Teresa Briggs

Dinorah Brillanti

Jorge Coutinho 
Maurício do Valle

Betty Faria

Alvaro Freire

Mário Gomes

Luiz Carlos Lacerda

Sebastião Lemos

Lucy Mafra

Célia Maracajá

Marcelo Marcello

Carmem Monegal

Ítala Nandi

Paulo Neves

Carmem Palhares

Ruy Polanah

Antônio Pompêo

Thaís Portinho

Helber Rangel

Marcos Rebu

Sílvia Salgado

Beatriz Segall

Jacyra Silva

Marcus Vinícius

Zaira Zambelli

\section{Sinopse}

Filme baseado na obra homônima de Aluisio Azevedo e conta a história de Rita Baiana, uma moradora de um cortiço de propriedade do português João Romão, uma mulher expansiva e liberada, que se apaixona pelo seu senhorio, uma paixão que acaba em tragédia.

Fonte:

http://epipoca.uol.com.br/filmes_detalhes.php?idf=7290

\section{Dama do Lotação, A (1976)}

\section{Ficha Técnica}

Título original: A Dama do Lotação

Gênero: Drama

Duração: 111 min.

Lançamento (Brasil): 1978

Distribuição: Atlantic

Direção: Neville de Almeida

Roteiro: Neville de Almeida, baseado em livro de Nélson Rodrigues

Produção: Alberto Fonseca e Walter Shilke

Música: Caetano Veloso

Fotografia: Edson Santos

Direção de arte: Gilberto Loureiro

Figurino: Marília Carneiro

Edição: Raimundo Higino

Elenco

Sônia Braga (Solange)

Nuno Leal Maia (Carlos)

Jorge Dória (Pai de Carlos)

Paulo César Pereio

Cláudio Marzo

Márcia Rodrigues

Paulo Villaça

Roberto Bonfim 


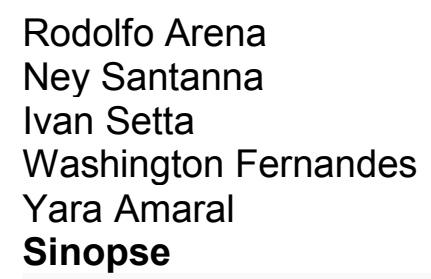

Carlos e Solange se amam desde jovens e, após um casto namoro, se casaram. Na noite de núpcias, Solange se recusa a fazer amor com ele. Primeiro ele implora, então em um acesso de raiva a estupra. Solange afirma que o adora, mas nos meses que se seguiram ao casamento ela não pode ser tocada por Carlos. Para provar a si mesma que não é frígida, começa uma rotina diária de seduzir homens em coletivos, homens que ela nunca viu nem verá novamente e nem mesmo sabe seus nomes. Além disto, ela tem relações com o melhor amigo de Carlos e até mesmo com seu sogro. Carlos entende que ela é infiel e, armado, confronta Solange. Enquanto isso, ela busca ajuda psiquiátrica, pois não sente nenhum remorso.

\section{Fonte:}

http://www.meucinemabrasileiro.com/filmes/dama-do-lotacao/dama-do-lotacao.asp

\section{Fogo Morto (1976)}

\section{Ficha Técnica}

Título original: Fogo Morto

Gênero: Drama

Duração: 88min.

Lançamento (Brasil): 1976

Distribuição: Embrafilme

Direção: Marcos Faria

Assistente de direção: Paulo Melo

Adaptação Cinematográfica: Salim Miguel

Roteiro: Marcos Faria, Salim Miguel e Eglê Malheiros

Produção: Miguel Borges, Renato Neumann e Cida Correia

Direção de Produção: Maria Aparecida Correia

Co-produção: Miguel Borges Produções Cinematográficas, Marcos Faria Produções

Cinematográficas, Fundação Cultural do Estado da Paraíba e Embrafilme

Música: Quinteto Armorial e Pedro Santos

Som: Onélio Motta e J. Fonseca

Fotografia: Renato Neumann

Maquiagem: Helena Teixeira

Cenografia: Raquel E. Sisson

Figurinos: Cida Correia

Montagem: Miguel Borges e Humberto Martins

\section{Elenco:}

Jofre Soares (Zé Amaro)

Othon Bastos (Lula de Holanda)

Rafael de Carvalho (Capitão Vitorino)

Ângela Leal (Amélia)

Rodolfo Arena (Cego Torquato)

Fernando Peixoto (Antonio Silvino)

Procópio Mariano (Zé Passarinho)

Vicentina Amaral (Sinhá)

Mary Neubauer (Marta)

Waldemar Solha (Tenente Maurício)

João Signorelli

Ivan Cândido (Narração)

\section{Sinopse}


Filme baseado no romance homônimo de José Lins do Rego que mostra a luta entre policiais e cangaceiros liderados pelo legendário Antônio Silvino. Alguns flashbacks nos reconduzem aos anos de 1886 e 1888 na região dos engenhos no Estado da Paraíba.

Fonte:

http://epipoca.uol.com.br/filmes_detalhes.php?idf=11839

http://www.meucinemabrasileiro.com/filmes/fogo-morto/fogo-morto.asp

\section{Guarani, O (1979)}

\section{Ficha Técnica}

Gênero: Aventura

Tempo de Duração: 135min.

Ano de Lançamento (Brasil): 1979

Distribuição: Embrafilme

Direção: Fauzi Mansur

Roteiro: Fauzi Mansur e Marcos Rey

Adaptação Cinematográfica: Fauzi Mansur e Marcos Rey

Texto: Ody Fraga

Produção: Fauzi Mansur

Produtor Associado: Manoel C. Alonso, João Luiz de Araújo, Sílvio Antônio dos Santos e

Luiz Carlos dos Santos

Direção de Produção: José Adauto Cardoso

Co-produção: Virgínia Filmes, Fauzi A. Mansur Cinematográfica e Embrafilme

Música: Augustinho Zaccaro e excertos de Carlos Gomes

Fotografia: Cláudio Portioli

Câmera: Cláudio Portioli

Cenografia: Laonte Klawa

Direção de arte: Paulo Tachinardi Domingues

Figurinos: Eliana Andreucci Faccio

Montagem: João de Alencar

\section{Elenco:}

David Cardoso

Dorothée-Marie Bouvier

Flávio Portho

Tony Correia

Luigi Picchi

Jofre Soares

Flora Geny

Solange Teodoro

Francisco Cúrcio

Roberto Miranda

Fernando Reski

Alberto Ruschel

Lino Sérgio

Ivo da Mata

Heitor Gaiotti

José Lopes

Josimar Martins

Orival Pessini

Paulo Mander

Enoque Batista

Abdala Mansur

Arcílio Custódio de Oliveira

Paulo Tachinardi Domingues

Lando Grandi

Manoel R. da Silva 
Domingos Samuel dos Santos

Sebastião dos Santos

Avelino Parreira

Sinopse

Filme baseado no romance homônimo de José de Alencar, conta a história de um amor proibido entre o índio Peri e a jovem branca Ceci.

Fonte:

http://www.meucinemabrasileiro.com/filmes/guarani-1979/guarani-1979.asp

\section{Iracema, a Virgem dos Lábios de Mel (1976)}

\section{Ficha Técnica}

Gênero: Aventura

Tempo de Duração: 98min.

Ano de Lançamento (Brasil): 1979

Distribuição: Embrafilme

Direção: Carlos Coimbra

Roteiro: Carlos Coimbra e Zaé Júnior

Argumento: Zaé Júnior

Diálogos: Zaé Júnior

Produção: Carlos Coimbra

Produção Executiva: Félix Aidar

Direção de Produção: Félix Aidar

Gerente de produção: Orlando Ramires

Assistente de produção: Enoque Batista

Co-produção: CSC Produções Cinematográficas, Distribuidora Internacional de

Filmes, Serrador Filmes e Embrafilme

Música: Vinícius de Moraes e Toquinho

Fotografia: Pio Zamuner e Antônio Meliande

Câmera: Pio Zamuner e Antônio Meliande

Figurinos: José Lanzelotti

Cenografia: Carlos Coimbra

Maquiagem: Mário L. Teixeira

Continuidade: Marinalva Travassos Montagem: Carlos Coimbra

Elenco:

Helena Ramos

Tony Correia

Francisco di Franco

Carlos Koppa

Alberto Ruschel

Mário Benvenutti Filho

Stael D'Almeida

Alvamar Santos

Ladislene Paula

Ilma Conceição

Dina Medeiros

Lourdes de Souza

Lucy Furtado

Domingos Samuel

Francisco Gomes

José Mateus Lopes

\section{Sinopse}

O filme é uma adaptação do romance homônimo de José de Alencar e narra a história de amor vivida entre o primeiro colonizador português do Ceará Martim e Iracema, uma índia tabajara.

Fonte: 
http://www.meucinemabrasileiro.com/filmes/iracema-virgem-dos-labios-de-mel/iracemavirgem-dos-labios-de-mel.asp

\section{Lenda de Ubirajara, A (1975)}

\section{Ficha Técnica}

Categoria: Longa-metragem / Sonoro / Ficção

Ano: 1975

Companhia produtora: André Luiz Oliveira Produções Cinematográficas; Alo Filmes

Companhia(s) produtora(s) associada(s): Makro Filmes; Thor Filmes; Grupo Filmes

Produção: André Luiz Oliveira

Direção de produção: Roberto Duarte

Produção executiva: Paulo Mauricio e José Petrilho

Produtores associados: K. M. Eckstein, Paulo Maurício C. Oliveira, Régis Monteiro e Arnaldo

Silveira

Assistência de produção: José Emidio, Celso Peçanha e Gino Myrtes

Financiamento/patrocínio: Embrafilme - Empresa Brasileira de Filmes S.A.

Coordenação de produção: Jesus Chediak

Companhia distribuidora: Embrafilme - Empresa Brasileira de Filmes S.A.

Roteiro: André Luiz Oliveira

Adaptação: André Luiz Oliveira e Antônio Castor

Direção: André Luiz Oliveira

Assistência de direção: Manuel Costa

Continuidade: Ana Ladeira

Direção de fotografia: Mário Cravo Neto

Assistência de fotografia: Cleber

Fotografia de cena: Jessel Buss dos Santos

Direção de som: Roberto Melo Leite e José Tavares

Som guia: Jom Tob Azulay

Montagem: Amauri Alves

Assistente de montagem: Lucia Maria L. C. Soares

Cenografia: Régis Monteiro

Assistencia de cenografia: Adomervil, Marcha Lenta, Papa-Terra, Antonio da Bahia e Jorge

Anápolis

Contra-regra/acessórios de cenografia: Aragão Lima

Música (Genérico): Tuzé de Abreu

Locação: Planalto Central - GO; Rio Araguaia - GO

Elenco:

Tarcísio José Alves (Ubirajara)

Ana Maria Miranda (Jandira)

Zélia Moura Costa (Araci)

Roberto Bonfim (Pojucã)

Antônio Gonçalves do Nascimento, (Itaquê)

Jesus Chediak

Jorge Anápolis

Antônio Carnera

Tep Kahok

Tatau Costa

Taíse Costa

Povo de Goiânia

\section{Sinopse}

Filme baseado no romance Ubirajara, o senhor da lança, de José de Alencar, que conta a saga do filho do chefe Araguaia que com o objetivo de ser reconhecido como guerreiro sai pela floresta, apaixona-se por uma jovem da tribo Tocantins e vence bravos guerreiros que os atacaram. 


\section{Fonte:}

http://cinemateca.gov.br/cgi-

$\mathrm{bin} / \mathrm{wxis}$.exe/iah/?IsisScript=iah/iah.xis\&base=FILMOGRAFIA\&lang=P\&nextAction=search\&e xprSearch $=I D=024808 \&$ format $=$ detailed. $p f t$

http://epipoca.uol.com.br/filmes ficha.php?idf=12032

Lucíola, o Anjo Pecador (1975)

\section{Ficha Técnica}

Título original: Lucíola, o Anjo Pecador

Gênero: Drama

Duração: 114min.

Lançamento (Brasil): 1975

Distribuição: Embrafilme

Direção: Alfredo Sternheim

Assistente de direção: Antônio Carlos Contrera

Argumento: Alfredo Sternheim

Roteiro: Alfredo Sternheim

Adaptação Cinematográfica: Alfredo Sternheim

Produção: Alfredo Palácios

Produtor Associado: Antônio Pólo Galante

Co-produção: Servicine - Serviços Gerais de Cinema e Embrafilme

Música: Mário Edson

Canções: Gondoleiro do amor: Antônio de Castro Alves

Fotografia: Antônio Meliande

Câmera: Antônio Meliande

Cenografia: Laonte Klava

Figurinos: Isabel do Amaral

Montagem: Maurício Wilke

Trucagens: Paolo Picchi

Títulos: Felipe Ricci

Adereços: Conceição Alencar

Penteados: Cecílio Giglioti

\section{Elenco:}

Rossana Ghessa

Carlo Mossy

Helena Ramos

Sérgio Hingst

Clemente Viscaino

Dorothy Leiner

Cavagnole Neto

Wanda Marchetti

Aparecida de Castro

Antônio Meliande

Antônio Moreira

Marcus Vinicius

Nelson Oliver

Oswaldo Ávila

Michel Cohen

Maria Luiza Muller

Tyhana Perckle

Mariana Silva

Cleide Singer

Alexa Leirner

Cleide Silva

Edna Erra

Lina Leirner

Roberta Marchetti 
Vivian Leirner

Wagner Gonçalves

Walter Sagarrov

Mary Penteado

Sinopse

Adaptação do clássico romance "Lucíola", de José de Alencar, no qual o autor caracteriza o ambiente burguês, seus hábitos, suas festas, suas crenças e ideais de vida, através da história de Paulo, que chega ao Rio de Janeiro, vindo de Recife, conhece Lucíola, mas descobre por seu amigo Sá que ela é uma espécie de cortesã que vive à disposição dos endinheirados.

Fonte:

http://www.meucinemabrasileiro.com/filmes/luciola-o-anjo-pecador/luciola-o-anjopecador.asp

\section{Morte e Vida Severina (1977)}

\section{Ficha Técnica}

Ano: 1977

Gênero: Drama

Duração: 85 min.

Tipo: Longa-metragem / Colorido

Distribuidora: Embrafilme

Produtora: Embrafilme, Mapa Filmes

Diretor: Zelito Viana

Roteirista: João Cabral de Melo Neto, Zelito Viana

\section{Elenco:}

Tânia Alves

José Dumont

Stênio Garcia

Luiz Mendonça

Elba Ramalho

Jofre Soares

\section{Sinopse}

Filme é uma adaptação do poema de João Cabral de Melo Neto, que retrata a vida do retirante nordestino que atravessa o agreste fugindo da seca e esperando encontrar em Recife uma vida melhor.

Fonte:

http://epipoca.uol.com.br/filmes_ficha.php?idf=11848

\section{Seminarista, $\mathrm{O}$ (1977)}

\section{Ficha Técnica}

Ano: 1977

Gênero: Drama

Duração: 101 min.

Tipo: Longa-metragem / Colorido

Distribuidora(s): Transvideo, Embrafilme

Produtora(s): Embrafilme, Lynselfilm, Vila Rica Produções Cinematográficas

Diretor: Geraldo Santos Pereira

Roteirista(s): Alphonsus de Guimarães Filho, Bernardo Guimarães, Afonso Henrique Neto, Geraldo Santos Pereira

Fotógrafo: José Medeiros

Produtor: César Memolo

Compositor: Edino Kruger

Montagem: Giuseppe Baldacconi 
Desenhista de Produção: Luiz Alphonsus

Figurinista: Sílvia Sangirardi

Supervisor de Produção: Adélia Sampaio

Som: Carla Civelli

Elenco:

Jotta Barroso

Xandó Batista

Fernando Caldeira

Vicente Câmara

Louise Cardoso

Raul Cortez

Cecil Costa

Liana Duval

Rossana Eva

Tony Ferreira

Beth Fisher

Ida Gomes

Sônia Gularducci

Guta Cristina Leal

Urbano Lóes

Eduardo Machado

Lídia Mattos

Nildo Parente

Marcelo Santos Pereira

Paulino Rafante

Fernando Reski

Dino Sirzi

Vicente Tropia

Sinopse

Filme baseado na obra literária de Bernardo Guimarães, conta a história de Eugênio, que por estar apaixonado por Margarida, uma jovem pobre, é enviado para o seminário. Anos depois, pouco antes d ser ordenado, Eugênio reencontra Margarida e os dois descobrem que a paixão ainda existe entre eles.

Fonte:

http://epipoca.uol.com.br/filmes_ficha.php?idf=11832

http://literar.org/text/t1kg5sp1k-analise-filmica---o-seminarista

\section{Senhora (1976)}

\section{Ficha Técnica}

Gênero: Romence/ Drama

Duração: 83 min

Lançamento: 1976

País: Brasil

Direção e Roteiro: Geraldo Vietri

Distribuição: CIC Videos

Elenco:

Elaine Cristina (Aurélia Camargo)

Paulo Figueiredo (Fernando Seixas)

Sadi Cabral

Aldo César

Ruthinéa de Moraes

Annamaria Dias (Adelaide Amaral)

Flamínio Fávero

Olívia Camargo

Nélson Caruso 
Pedro Cassador

Marilena de Carvalho

Etty Fraser (Firmina Mascarenhas)

Flávio Galvão (Eduardo Abreu)

Elizabeth Hartmann (Lísia)

Yara Lins (Emília Lemos Camargo)

Chico Martins (Lemos)

Amilton Monteiro

Leonor Navarro (Camila Seixas)

Francisco Petrônio

Marcos Plonka

Pedro Paulo Zuppo

\section{Sinopse}

Filme é uma adaptação do livro de mesmo nome de autoria de José de Alencar, que conta a história de Aurélia, moça pobre e sem esperanças de casar-se por não dispor de um dote. Vive um breve mas intenso namoro com Fernando Seixas, rapaz vaidoso e endividado que, embora apaixonado por ela, abandona-a, seduzido pela oferta de um dote, comprometendose com outra moça. Depois de herdar uma grande fortuna, Aurélia casa-se com Fernando para vingar-se dele.

Fonte:

http://wapedia.mobi/pt/Senhora \%28filme\%29

http://entrefilmes.blogspot.com/2007/11/senhora-jos-de-alencar-1976.html

\section{Tenda dos Milagres, A (1977)}

\section{Ficha Técnica}

Ano: 1977

Gênero: Drama

Duração: 132 min.

Distribuidora: Riofilme

Produtora: Regina Filmes

Diretor: Nelson Pereira dos Santos

Roteiristas: Jorge Amado e Nelson Pereira dos Santos

Fotógrafo: Hélio Silva

Produtor(es): Tininho Nogueira da Fonseca, Ivan De Souza, Carlos Alberto Diniz e

Francisco Drummond e Ney Santanna

Compositor música original: Gilberto Gil

Montagem: Severino Dada e Raimundo Higino

Desenhista de Produção: Tizuka Yamasaki

Figurinista: Yurika Yamasaki

Maquiagem: Antonio Pacheco

Diretor(es) Assistente(s): Agnaldo Siri Azevedo, Emmanuel Cavalcanti e

Ana María Miranda

Departamento de Som: Geraldo José

\section{Elenco:}

Hugo Carvana

Sonia Dias

Anecy Rocha

Franca Teixeira

Mae Mirinha do Portão

Juárez Paraíso

Jards Macalé

Jehova de Carvalho

Manoel do Bonfim

Nildo Parente

Arildo Deda 


\author{
Gildasio Leite \\ José Passos Neto \\ Jofre Soares \\ Nilda Spencer \\ Alvaro Guimarães \\ Fernanda Amado \\ Jurema Penna \\ Jorge Cerqueira De Amorim \\ Maria Adélia \\ Washington Fernandes \\ Emmanuel Cavalcanti \\ Luis da Moricoca \\ Maria Pequena \\ Mãe Runho do Bogum \\ Dorival Caymmi \\ Geraldo Freire \\ Elke Maravilha \\ Jorge Mello \\ Sinopse
}

Filme é uma adaptação do romance de Jorge Amado de mesmo nome, que se passa no início do século 20, e retrata o bedel da Faculdade de Medicina que passa a defender seus ancestrais africanos.

Fonte:

http://epipoca.uol.com.br/filmes_ficha.php?idf=2592

http://melhoresfilmes.com.br/filmes/tenda-dos-milagres 